PNNL-11789

UC-702

\title{
HANFORD PROTOTYPE-BARRIER STATUS REPORT: FY 1997
}
A. L. Ward
G. W. Gee
S. O. $\operatorname{Link}^{(a)}$

December 1997

Prepared for the U.S. Department of Energy under Contract DE-AC06-76RLO 1830 (Work Order P70002-Bechtel Hanford, Inc.)

Pacific Northwest National Laboratory

Richland, Washington 99352

(a) Washington State University 


\section{DISCLAIMER}

This report was prepared as an account of work sponsored by an agency of the United States Government. Neither the United States Government nor any agency thereof, nor any of their employees, make any warranty, express or implied, or assumes any legal liability or responsibitity for the accuracy, completeness, or usefulness of any information, apparatus, product, or process disclosed, or represents that its use would not infringe privately owned rights. Reference herein to any specific commercial product, process, or service by trade name, trademark, manufacturer, or otherwise does not necessarily constitute or imply its endorsement, recommendation, or favoring by the United States Government or any agency thereof. The views and opinions of authors expressed herein do not necessarily state or reflect those of the United States Government or any agency thereof. 


\section{DISCLAIMER}

Portions of this document may be illegible electronic image products. Images are produced from the best available original document. 


\section{Summary}

An above-grade surface barrier consisting of a vegetated soil-cover, surrounded by gravel and rock side slopes, is being tested for the U. S. Department of Energy (DOE). It is part of a treatability study at the 200-BP-1 Operable Unit in the 200 East Area of the Hanford Site, near Richland, Washington. The surface barrier, constructed in 1994, covers 2.5 ha (6.9 acre) of land surface and is situated over an inactive liquid-waste disposal crib. A set of under drains, built into the barrier using curbed asphalt, allows precise measurement of drainage from the soil cover and the side slopes. The treatability test includes measurements of water balance, wind and water erosion, subsidence, plant growth, and plant and animal intrusion. The test compares the performance of the barrier under ambient and simulated climate change (elevated precipitation) conditions. This report documents findings from the third year of testing.

Irrigation water was applied to the northern half of the barrier for the past three water years (November through October). For Water Year-1997 (WY-1997), the total water applied (including precipitation) was $504 \mathrm{~mm}$ (19.8 in.). This was $24 \mathrm{~mm}$ (0.9 in.) in excess of the target amount of 480 $\mathrm{mm} \mathrm{yr}^{-1}$ (18.9 in. $\left.\mathrm{yr}^{-1}\right)$ applied in each of the previous $2 \mathrm{WY}$. The winter season (December through February) had $138 \mathrm{~mm}$ ( $5.4 \mathrm{in}$.) of natural precipitation, and was the wettest season ever recorded at the Hanford Site. Some water accumulation at the edges of the soil surface was noted in January and attributed to snowmelt conditions. Four surface runoff events occurred in WY-1997 generating a total of $36.3 \mathrm{~mm}$ (1.4 in.) of runoff. For WY-1997, the cumulative irrigation coupled with natural precipitation was at a record $275 \mathrm{~mm}$ (10.8 in.) by the last week of March. On March 26, an additional $71 \mathrm{~mm}$ (2.8 in.) of irrigation water (simulating a 1000-year storm event) was added to the northern half of the barrier's surface in less than $8 \mathrm{hr}$. No runoff from the barrier's surface was noted during the irrigation treatment. The lack of runoff from the simulated 1000 -year storm is attributed to vegetation and its impact on surface stability and permeability.

A total of $0.2 \mathrm{~mm}(1 / 127 \mathrm{in}$.) of drainage was measured on the irrigated, northeast soil plot through October 31, 1997. The drainage began after the third 1000-year storm application in March 1997 and continued at a slow but steady rate for the next 7 months. Drainage from the northeast plot is attributed to a change in vegetation type in the soil test plot area. Drainage vaults connected to the remaining soil plots have registered very small amounts of water, generally less than $0.02 \mathrm{~mm}(1 / 1270 \mathrm{in}$.) over the last 3 year. This water is attributed to condensation in the drainage pipes.

Side slope drainage has persisted over the past three years. From July 1996 through August 1997 , drainage from the irrigated basalt rock and the gravel side slopes was nearly the same (about $40 \%$ of the applied water). In contrast, the drainage from the non-irrigated rock and gravel side slopes was markedly different, with the gravel side slope draining about $30 \%$ of the precipitation, and the non-irrigated rock side slope draining only about $20 \%$. Drainage from the rock and gravel side slopes on the prototype barrier continued at less than that observed in nearby lysimeters containing similar cover materials. The lower drainage rates from the prototype side slopes are attributed primarily to advective drying. The 
prototype barrier design, with large basalt rock on the side slope connected to coarse rock in the sublayers, tends to optimize natural advective drying conditions. The enhanced drying of the side slopes may reduce water content in the soil cover, but it does not prevent drainage.

Water content changes were measured at the edge and underneath the barrier, using neutron probes to scan horizontal access tubes located at depths of 1,2 , and $3 \mathrm{~m}(0.1 \mathrm{in}$. or less) below the asphalt at the base of the prototype barrier. After three years of testing, the data show that increases in water content occur within $2 \mathrm{~m}(6.6 \mathrm{ft})$ of the asphalt edge. While water content change does not determine flux rates, the data suggest that most, if not all, of the lateral flow water is being diverted away from the asphalt edge and that subsurface water content changes are confined to the edge and outside of the asphalt pad. Similar observations have been made with the horizontal probes for the past three years.

Topographic surveys completed on the prototype barrier during the past 3 years show no significant change in settlement of the barrier. An elevation increase of slightly more than $1 \mathrm{~cm}(0.4 \mathrm{in}$.) during the past three years is attributed to biomass (plant root) accumulation in the surface soil. Small random movements were detected in the creep gauges located on the rock side slope with an average downslope movement of less than $2 \mathrm{~cm}(0.8 \mathrm{in}$.). This amount of movement is considered negligible.

Wind erosion on soil surfaces was estimated in 1997 by visual inspection and measurement of gravel contents. The average gravel concentration of the soil surface has dropped to about $13 \%$ and, while not statistically different from the as-built value, supports the observation of increased organic matter in the soil surface. No evidence is found of significant soil accumulation from wind action, although it is clear that plant litter and roots have increased in the top 5 to $10 \mathrm{~cm}$ ( 2 to $4 \mathrm{in}$.) of the soil surface over the past three years. Increases in organic matter appear to account for the reduction in gravel content at the surface.

During the past year, vegetation cover on the prototype barrier changed slightly. On the irrigated treatments, a shift continued from shrubs to grasses with grasses occupying more than $50 \%$ of the surface area, particularly along the northernmost edge of the soil surface. Survival rate for sagebrush (Artemisia tridentata) continued to be high (above 90\%), while survival of rabbitbrush (Chrysothanmus nauseosus) was below $50 \%$. The rock side slope continued to remain free of vegetation, while the gravel side slope exhibited a very slight increase in vegetation cover (mostly annual grasses). The cover percentage for the top $50 \mathrm{~m}(164 \mathrm{ft})$ of the slope was less than $10 \%$. The lower $10 \mathrm{~m}(32.8 \mathrm{ft})$ (the toe of the slope) averaged about $30 \%$ cover. The lower part of the slope also appears to contain the highest quantity of fines. In areas on the gravel side slope, where trenches were dug, silt in-filling resulted in distinct areas of increased vegetation. Animal intrusion was more extensive in 1997 , with more than $80 \%$ of the surface showing signs of animal presence. Actual burrowing was restricted; only 10 small burrows were found on the surface barrier. These burrows are attributed to pocket mice and ground squirrels, with no evidence during three years of testing that larger mammals had invaded the surface.

This treatability test demonstrates that surface barriers can perform successfully over a 3-year test period. Resolution of the issues of vegetation stability and impacts of side slope drainage remain. 


\section{Acknowledgments}

We thank our support staff, Ray Clayton, Gary Dennis, Janelle Downs, Bonnie Knight, Dave Lanigan, Tara O'Neil, Bill Perkins, Jason Ritter, and Sally Simmons, who assisted in testing and monitoring the prototype during the year. We also thank Curtis Wittreich, of CH2M Hill, Mark Buckmaster, and Greg Mitchem of Bechtel Hanford Inc., and Bryan Foley, of the U.S. Department of Energy, Richland Operations, who have provided management oversight and support to this work.

Funding for testing and monitoring of the prototype was provided by the U.S. Department of Energy's Environmental Restoration Program (EM-40), through Contract DE-AC06-76RLO 1830 and work orders from Bechtel Hanford Inc. 


\section{Acronyms}

$\begin{array}{ll}\text { DOE } & \text { Department of Energy } \\ \text { DOY } & \text { Day of year } \\ \text { EDM } & \text { Electronic Distance Measurement } \\ \text { EI } & \text { Erosivity Index } \\ \text { ET } & \text { evapotranspiration } \\ \text { FLTF } & \text { Field Lysimeter Test Facility } \\ \text { FY } & \text { Fiscal year (Oct. 1 through Sep. 30) } \\ \text { HDU } & \text { Heat dissipation unit } \\ \text { HMS } & \text { Hanford Meteorological Station } \\ \text { LAI } & \text { leaf area index } \\ \text { LTA } & \text { Long-term average (precipitation) } \\ \text { NP } & \text { neutron probe } \\ \text { PNNL } & \text { Pacific Northwest National Laboratory } \\ \text { PSB } & \text { prototype surface barrier } \\ \text { RO } & \text { runoff. } \\ \text { TDR } & \text { time domain reflectometry } \\ \text { WY } & \text { Water year (November 1 through October 31) }\end{array}$




\section{Symbols}

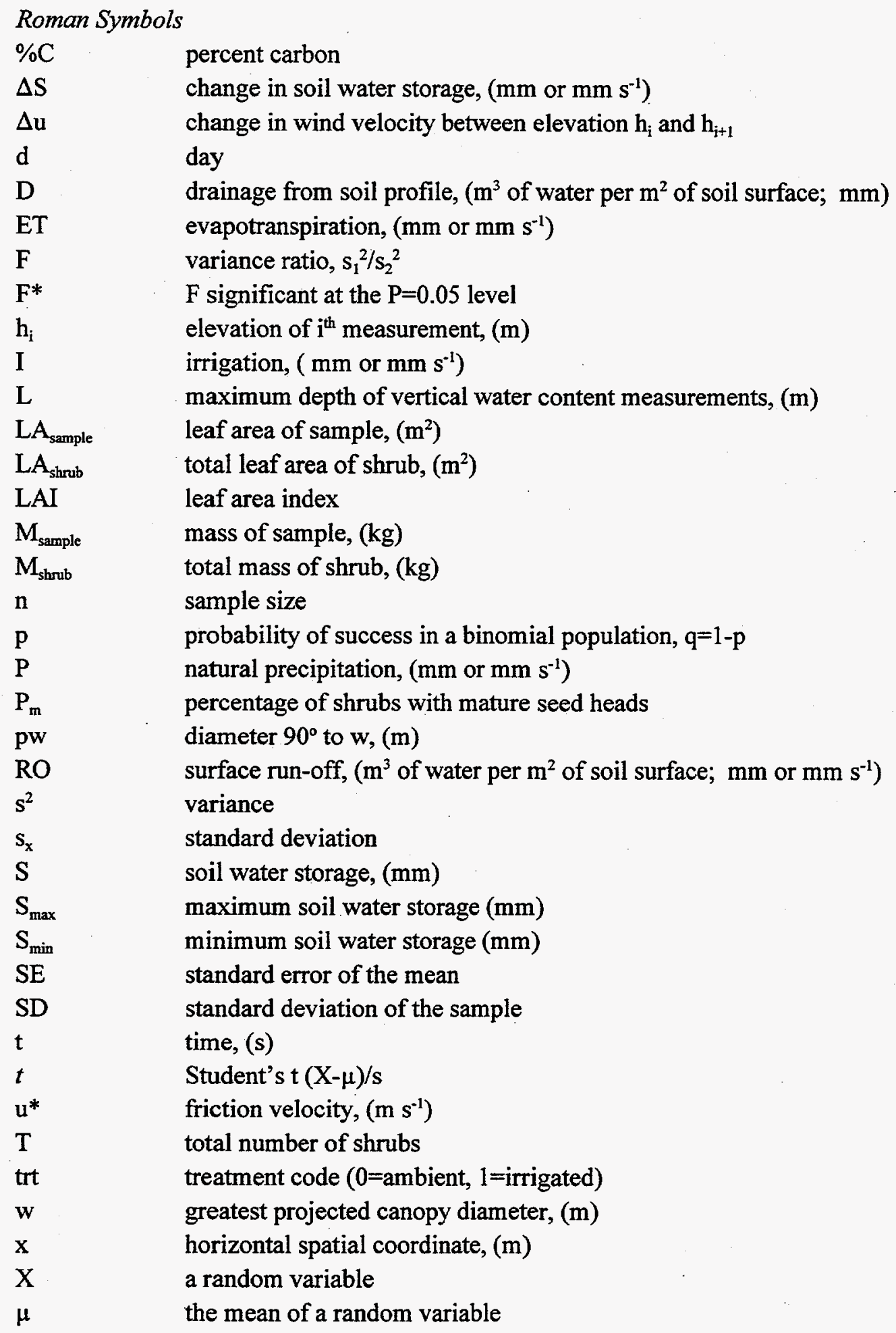

percent carbon

change in soil water storage, $\left(\mathrm{mm}\right.$ or $\mathrm{mm} \mathrm{s}^{-1}$ ).

change in wind velocity between elevation $h_{i}$ and $h_{i+1}$

day

drainage from soil profile, $\left(\mathrm{m}^{3}\right.$ of water per $\mathrm{m}^{2}$ of soil surface; $\mathrm{mm}$ )

evapotranspiration, $\left(\mathrm{mm}\right.$ or $\left.\mathrm{mm} \mathrm{s}^{-1}\right)$

variance ratio, $\mathrm{s}_{1}{ }^{2} / \mathrm{s}_{2}{ }^{2}$

$F$ significant at the $\mathrm{P}=0.05$ level

elevation of $i^{\text {th }}$ measurement, (m)

irrigation, ( $\mathrm{mm}$ or $\mathrm{mm} \mathrm{s}^{-1}$ )

maximum depth of vertical water content measurements, $(\mathrm{m})$

leaf area of sample, $\left(\mathrm{m}^{2}\right)$

total leaf area of shrub, $\left(\mathrm{m}^{2}\right)$

leaf area index

mass of sample, $(\mathrm{kg})$

total mass of shrub, $(\mathrm{kg})$

sample size

probability of success in a binomial population, $q=1-p$

natural precipitation, ( $\mathrm{mm}$ or $\mathrm{mm} \mathrm{s}^{-1}$ )

percentage of shrubs with mature seed heads

diameter $90^{\circ}$ to $\mathrm{w},(\mathrm{m})$

surface run-off, ( $\mathrm{m}^{3}$ of water per $\mathrm{m}^{2}$ of soil surface; $\mathrm{mm}$ or $\mathrm{mm} \mathrm{s}^{-1}$ )

variance

standard deviation

soil water storage, $(\mathrm{mm})$

maximum soil water storage $(\mathrm{mm})$

minimum soil water storage $(\mathrm{mm})$

standard error of the mean

standard deviation of the sample

time, (s)

Student's $t(X-\mu) / s$

friction velocity, $\left(\mathrm{m} \mathrm{s}^{-1}\right)$

total number of shrubs

treatment code ( $0=$ ambient, $1=$ irrigated $)$

greatest projected canopy diameter, $(\mathrm{m})$

horizontal spatial coordinate, (m)

a random variable

the mean of a random variable 
$\mathrm{Y}$

z

Z

$z_{\mathrm{o}}$

\section{Greek Symbols}

$\alpha$

$\kappa$

$\theta$

$\Theta$

$\rho_{b}$

$\Psi$ predicted leaf area $\left(\mathrm{m}^{2}\right)$

depth in soil profile, $(\mathrm{m})$

distribution of a standardized variable, $(\mathrm{X}-\mu) / \mathrm{s}$

mean roughness height, $(\mathrm{m})$

probability of type I error

von Karmon constant

volumetric soil water content, $\left(\mathrm{m}^{3}\right.$ of water per $\mathrm{m}^{3}$ of dry soil; $\mathrm{m}^{3} \mathrm{~m}^{-3}$ )

bearing, (radians)

bulk density, $\left(\mathrm{Mg} \mathrm{m}^{-3}\right)$

matric potential, $\left(\mathrm{J} \mathrm{kg}^{-1}\right)$ 


\section{Contents}

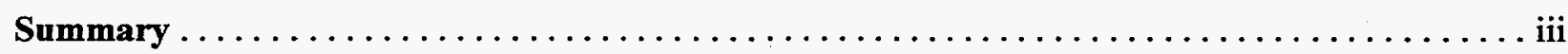

Acknowledgments $\ldots \ldots \ldots \ldots \ldots \ldots \ldots \ldots \ldots \ldots \ldots \ldots \ldots \ldots \ldots \ldots \ldots \ldots \ldots \ldots \ldots \ldots \ldots$

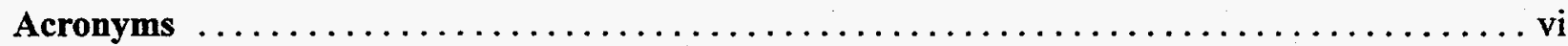

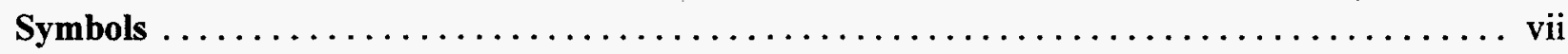

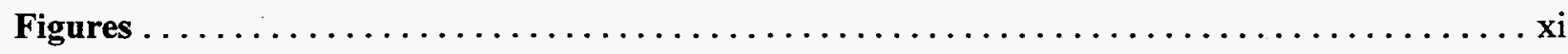

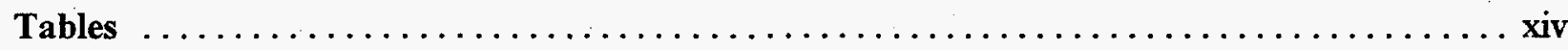

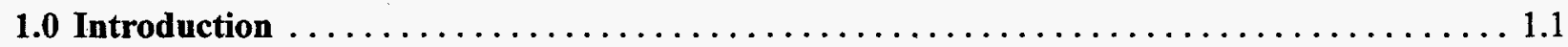

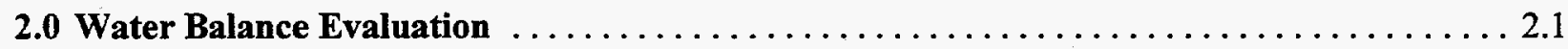

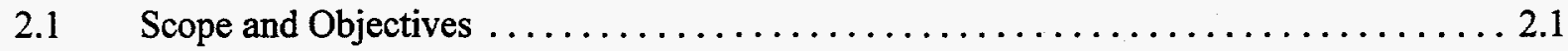

$2.2 \quad$ Water Balance Testing and Monitoring Activities $\ldots \ldots \ldots \ldots \ldots \ldots \ldots \ldots \ldots \ldots \ldots \ldots \ldots \ldots \ldots$

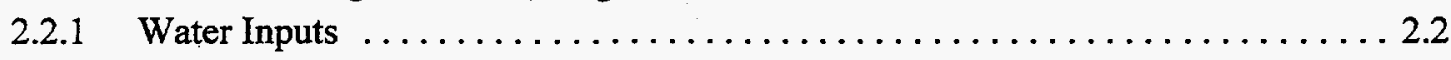

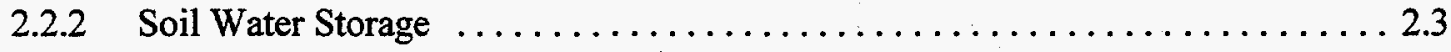

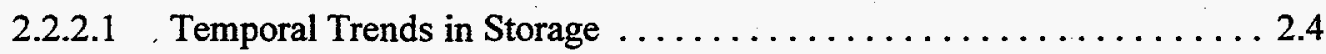

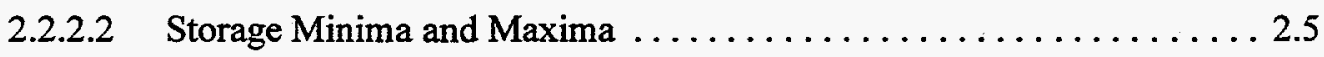

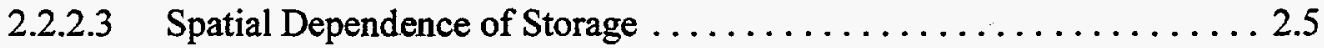

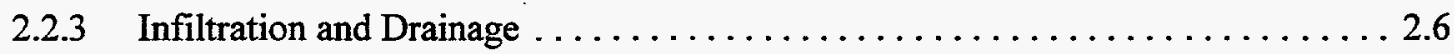

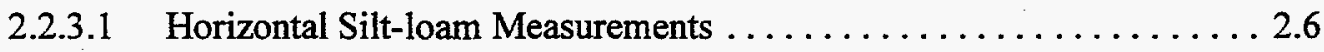

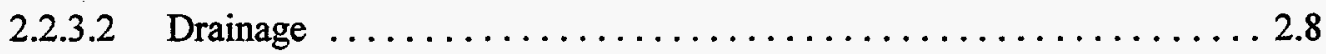

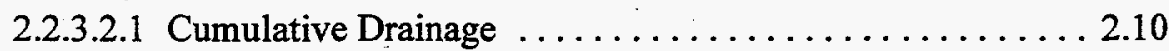

2.2.3.2.2 Side-slope Drainage Hypothesis . . . . . . . . . 2.11

2.2.3.2.3 Silt-loam Drainage Hypothesis . . . . . . . . . . 2.13

2.2.3.3 Performance of the Asphalt Layer . . . . . . . . . . . . . . 2.14

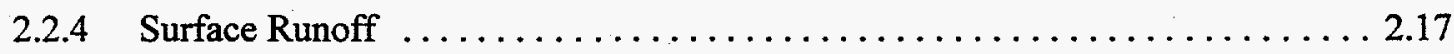

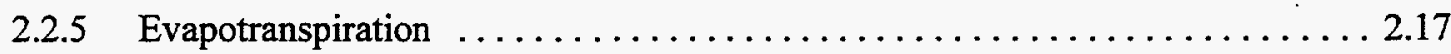

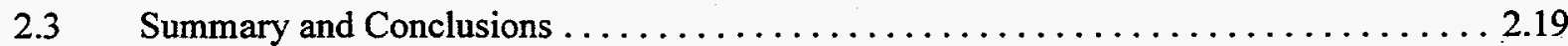

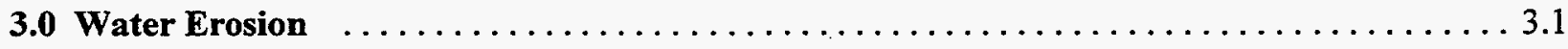

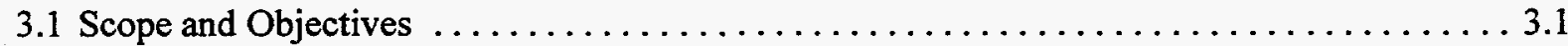

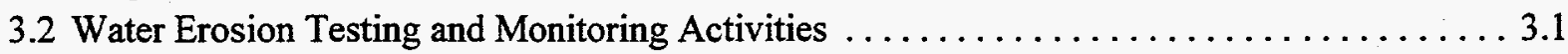

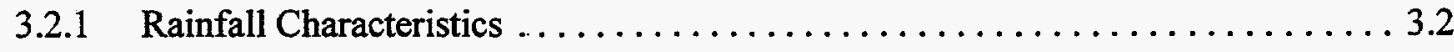

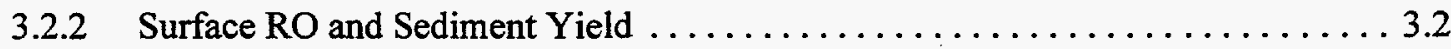

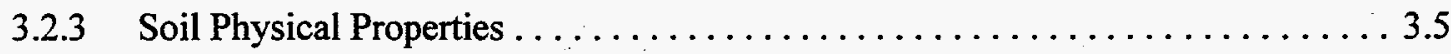

3.2.3.1 Near-Surface Soil Bulk Density . . . . . . . . . . . . . 3.5 


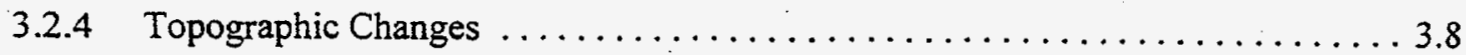

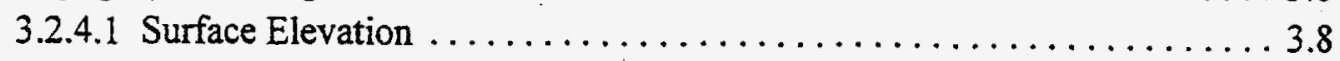

3.2.4.2 Settlement and Creep Gauge Movement .............. 3.10

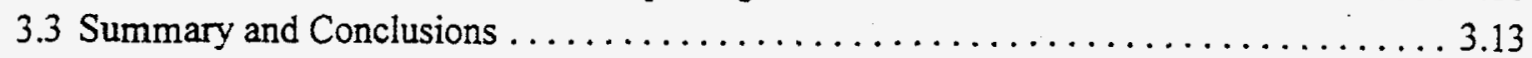

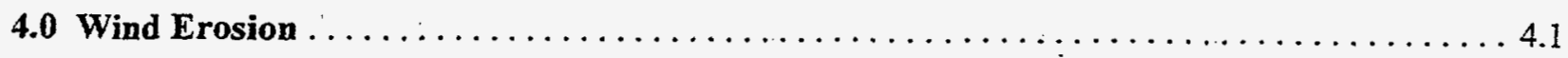

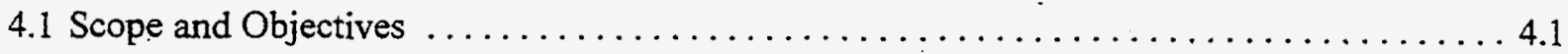

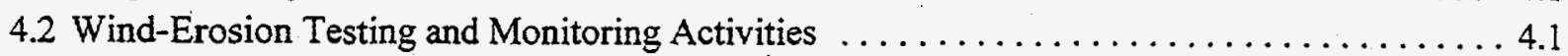

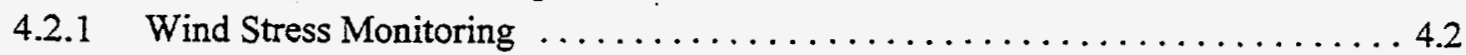

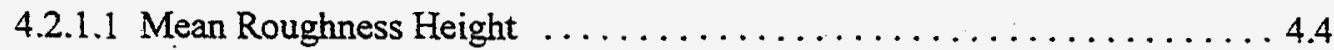

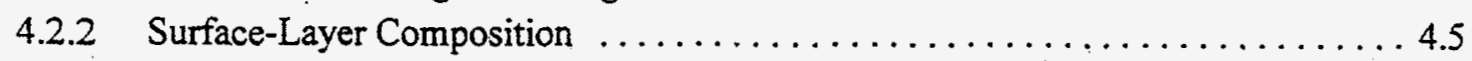

4.2.2.1 Pea Gravel Content in Bulk and Surface Samples . . . . . . . . . . 4.5

4.2.2.2 Dry Soil Density of Bulk and Surface Samples ... . . . . . . . . 4.7

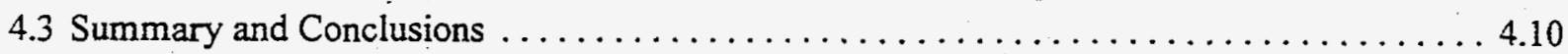

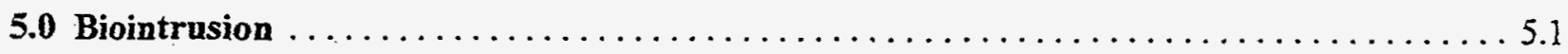

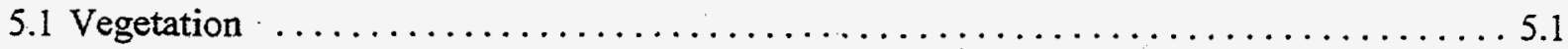

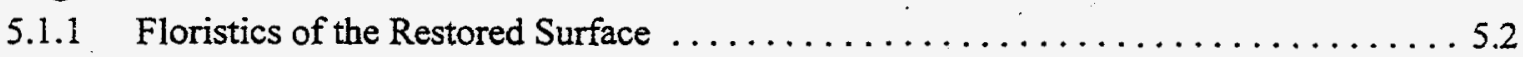

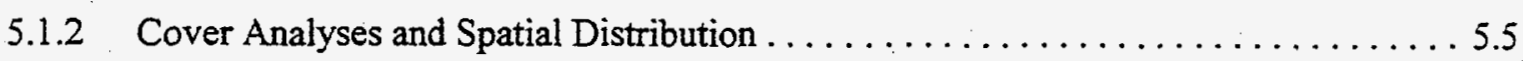

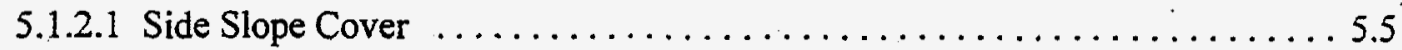

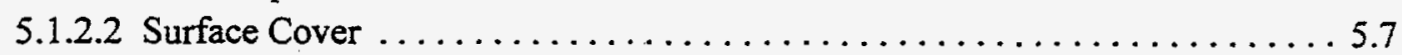

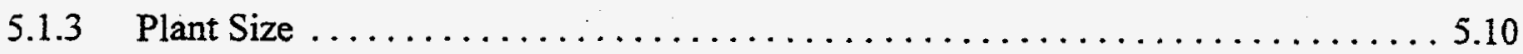

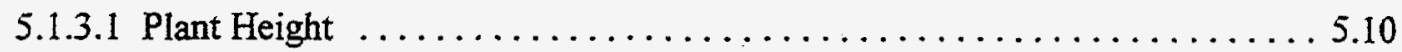

5.1.3.2 Artemisia tridentata Canopy Characteristics and Leaf Area ......... 5.16

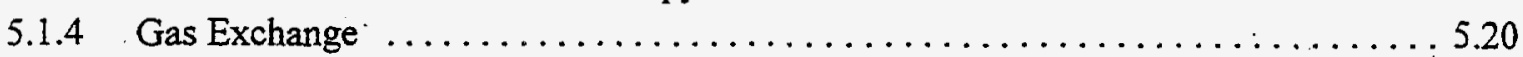

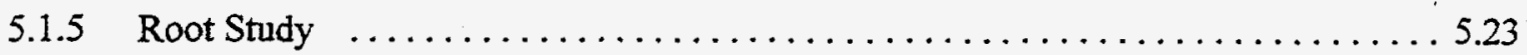

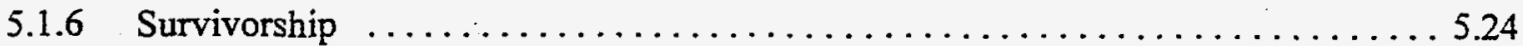

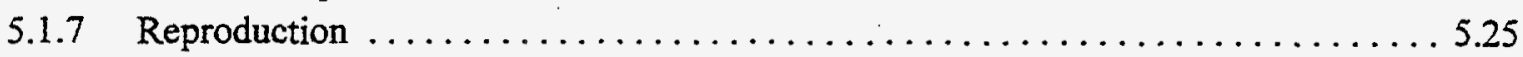

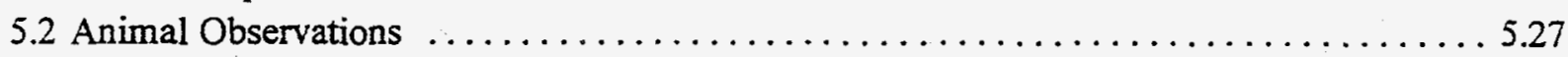

5.3 Summary and Conclusions $\ldots \ldots \ldots \ldots \ldots \ldots \ldots \ldots \ldots \ldots \ldots \ldots \ldots \ldots \ldots \ldots \ldots \ldots \ldots \ldots \ldots \ldots \ldots \ldots \ldots \ldots .28$

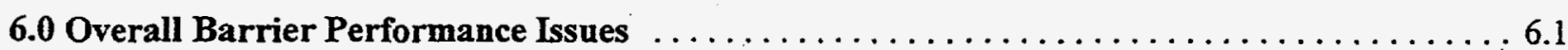

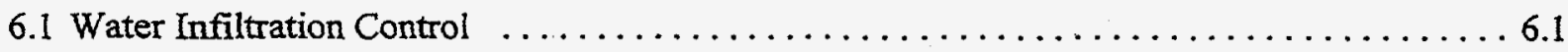

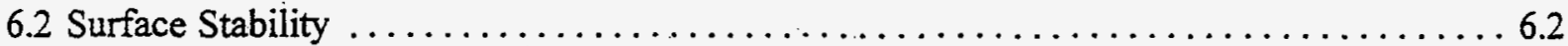

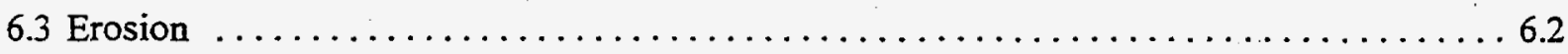

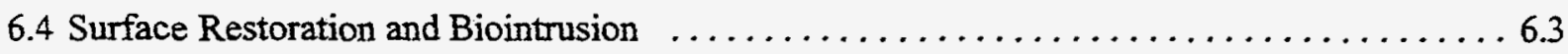

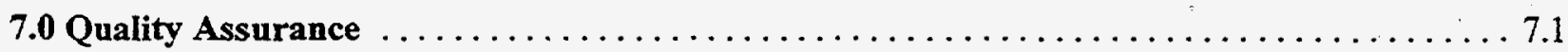

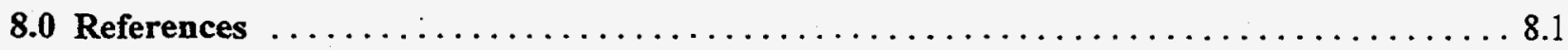

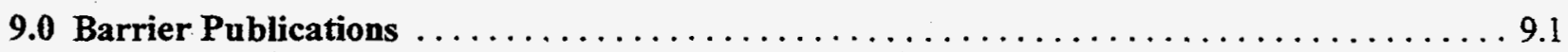




\section{Figures}

1.1 Schematic of Hanford Barrier Showing Cross Sections $\ldots \ldots \ldots \ldots \ldots \ldots \ldots \ldots \ldots \ldots \ldots$

1.2 Plan View of Prototype Surface Barrier Showing the Layout of the 12 Water Collection Zones

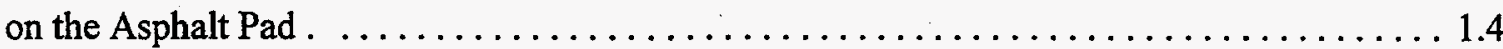

1.3 Plan View of the Barrier's Surface Showing the 3-m x 3-m Grid and Relative Positions of the

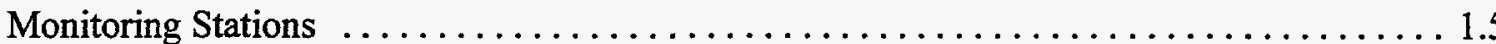

1.4 Measurement, Instrumentation, and Data Collection Flow Diagram for the Prototype Surface

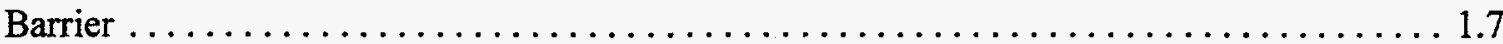

1.5 Prototype Surface Barrier at the 200 BP-1 Operable Unit, 200 East Area, Hanford Site,

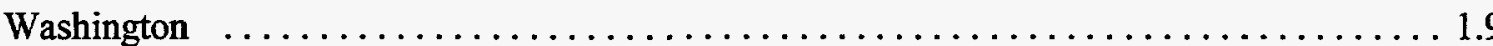

2.1 Cumulative 3-year Precipitation Data for Barrier Testing and Monitoring $\ldots \ldots \ldots \ldots 2.3$

2.2 Temporal Variation in Soil Water Storage at the Barrier November 1994 - October $1997 \ldots 2.4$

2.3 Spatial/Temporal Variations in Soil Water Content at Capillary Break - Irrigated

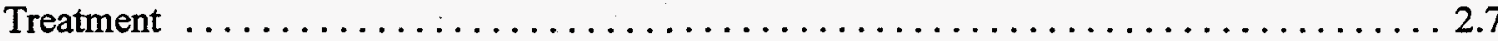

2.4 Spatial/Temporal Variations in Soil Water Content at Capillary Break - Non-irrigated

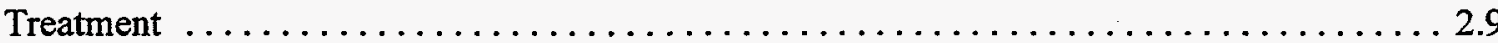

2.5 Temporal Variation in Water Content at Capillary Break of the Barrier $\ldots \ldots \ldots \ldots .10$

2.6 Cumulative Drainage from 12 Collection Zones on the Asphalt Pad of Barrier ........ 2.11

2.7 Temporal Changes in Matric Potential as Estimated with Heat Dissipation Units $\ldots \ldots \ldots 2.15$

2.8 Spatial/Temporal Variations in Soil Water Content at $1 \mathrm{~m}$ Below the Asphalt Layer .... 2.16

2.9 Cumulative Water Volume Recovered from the Below-Asphalt Lysimeter in FY $1997 \ldots 2.18$

3.1 Cumulative Precipitation Versus Time on January $18,1997 \ldots \ldots \ldots \ldots \ldots \ldots \ldots \ldots$

3.2 History of Surface RO Events in WY-1997 (a) Flow Rates, (b) Cumulative RO . . . . .. 3.4

3.3 Near-Surface $(\leq 20 \mathrm{~cm})$ Dry Bulk Densities $\left(\mathrm{kg} \mathrm{m}^{-3}\right)$ at the Prototype Surface Barrier $\ldots \ldots 3.6$ 
3.4 Change in Near-Surface $(\leq 20 \mathrm{~cm})$ Dry Bulk Densities $\left(\mathrm{kg} \mathrm{m}^{-3}\right)$ at the Prototype Surface Barrier Between August 26, 1996 and September 2, $1997 \ldots \ldots \ldots \ldots \ldots \ldots \ldots \ldots \ldots . \ldots \ldots$

3.5 Surface Elevations at the Prototype Surface Barrier During FY-1997 $\ldots \ldots \ldots \ldots \ldots .8$

3.6 Change in Surface Elevation at the Prototype Surface Barrier Between January 8, 1997 and September 4, 1997

3.7 Change in Surface Elevation at the Prototype Surface Barrier Between December 16, 1994 and September 4, 1997

3.8 Cumulative Summary of Changes in Settlement Gauge Elevation Between November 1,

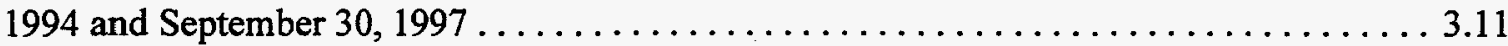

3.9 Creep Gauge Movement Between January 8, 1997 and September 4, $1997 \ldots \ldots \ldots .12$

3.10 Creep Gauge Movement Between December 16, 1994 and September 4, 1997 . . . . . . 3.13

3.11 Creep Gauge Movement Relative to the First Civil Survey on December 16, $1994 \ldots \ldots \ldots 3.14$

4.1 Typical Wind Profiles Over the Barrier Site Measured on September 24, 1997. . . . ... 4.3

5.1 Number of Annual and Perennial Species Including Total Number of Species on

Barrier's Surface

5.2 Percent Cover of Litter, Bare Ground, Perennial Grasses Plus Annual or Biennial Plant Species on the West Facing Side Slope

5.3 Percent Cover of Grasses on the Surface $\ldots \ldots \ldots \ldots \ldots \ldots \ldots \ldots \ldots \ldots \ldots \ldots \ldots \ldots \ldots \ldots \ldots$

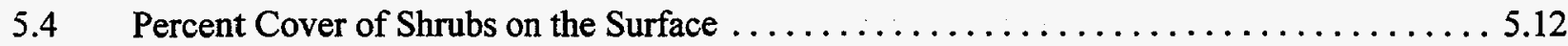

$5.5 \quad$ Percent Cover of Herbaceous Forbs on the Surface $\ldots \ldots \ldots \ldots \ldots \ldots \ldots \ldots \ldots \ldots \ldots$

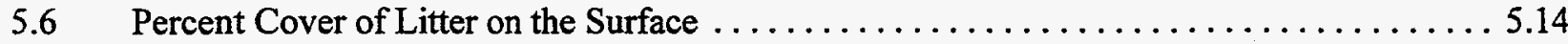

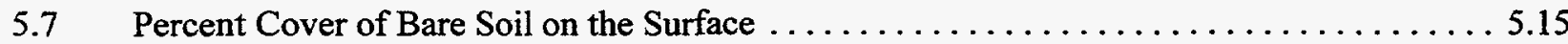

5.8 Height of Chrysothamnus nauseosus from WY-1995 to WY-1997 in Irrigated and Nonirrigated Treatments 
5.9 Height of Artemisia tridentata from WY-1995 to WY-1997 in Irrigated and Nonirrigated Treatments

5.10 Predicted Leaf Area Using Equation 5.2 Correlated with Observed Leaf Area for Artemisia tridentata

5.11 Predicted Mean Canopy Leaf Area of Artemisia tridentata for the Irrigated and Nonirrigated Treatments over 3 Months in WY-1997

5.12 Transpiration Rates for Artemisia tridentata Collected in WY-1995, WY-1996, and WY-1997 in the Irrigated and Non-irrigated Treatments

5.13 Net Photosynthesis in Artemisia tridentata Collected in WY-1995, WY-1996, and WY-1997 in the Irrigated and Non-irrigated Treatments

5.14 Mean Root Length Density as a Function of Depth in WY-1995, WY-1996, and WY-1997 for (a) the Non-irrigated Treatment, and (b) the Irrigated Treatment

5.15 Mean Root Length Density over Depths and Holes in WY-1995, WY-1996, and WY-1997 for the Non-irrigated and Irrigated Treatments .

5.16 Mean Ratio of Dead to Live Root Length Density in WY-1997 for the Non-Irrigated and Irrigated Treatments

5.17 Mean Survivorship for Artemisia tridentata and Chrysothamnus nauseosus in WY-1995, WY-1996, and WY-1997 for the Non-Irrigated and Irrigated Treatments

5.18 Animal Evidence in Each Quadrat on the Surface 5.28 


\section{Tables}

1.1 Expected Measurement Precision for Water Balance, Stability, and Biointrusion Monitoring at the Prototype Surface Barrier .

2.1. Amounts of Water Diverted by the Asphalt Pad (Drainage) at the Prototype Barrier and the Relationship to Precipitation.

2.2 Water Balance Summary for the Soil-covered Plots at the Prototype Barrier

4.1 Mean \% Pea Gravel Content $(\bar{G})$ and the Standard Deviation of the Mean $\left(\sigma_{\bar{G}}\right)$ of Near-Surface and Bulk Samples Obtained from the Prototype Surface Barrier

4.2. Mean Admixture Dry Densities, $\overline{\rho_{b}}$, and the Standard Deviation of the Mean $\left(\sigma_{\bar{\rho}}\right)$ of Near-Surface and Bulk Samples Obtained from the Prototype Surface Barrier

4.3. Mean Silt Loam Dry Densities, $\bar{\rho}_{\mathrm{b}}$ and the Standard Deviation of the Mean $\left(\sigma_{\bar{\rho}}\right)$ of Near-Surface and Bulk Samples Obtained from the Prototype Surface Barrier.

5.1. Plant Species Observed on the Prototype Surface Barrier

5.2. Median and Mode of the Percent Cover Classes.

5.3. Mann-Whitney $U$ Test Results for Cover Class Comparison Between Years Within Treatments and Between Treatments Within Year

5.4. Estimated Leaf Area Index of Artemisia tridentata in Each Treatment in WY-1997

5.5. Percentage of Artemisia tridentata Shrubs with Mature Seed Heads in the Irrigated and Non-irrigated Treatments. 


\subsection{Introduction}

Surface barriers continue to be an option for isolating certain wastes at the Hanford Site. More than 230 waste sites that may use surface barriers have been identified (DOE 1996). Surface barriers are intended to isolate wastes from the accessible environment and to provide long-term protection to future populations that might use the Hanford Site. Currently, no proven long-term barrier system is available. For this reason, a treatability study was initiated at the 200-BP-1 Operable Unit in the 200 East Area of the Hanford Site, consisting of the construction and performance testing of a prototype surface barrier (DOE 1993).

The prototype surface barrier (PSB) is a 2.5-ha, vegetated, multilayered, capillary barrier that covers an existing waste site (B-57 Crib). The PSB is constructed from naturally occurring materials, including silt loam, sand, gravel, basalt riprap $(0.25 \mathrm{~m}$ fractured basalt $)$, and asphalt. These materials were selected to optimize barrier performance and longevity (Wing and Gee 1994). The layers were designed and arranged to limit recharge and, therefore, waste transport by infiltrating water; limit erosion of overlying soil by wind and water; resist deep penetration by burrowing animals and roots; and limit emission of noxious gases from decaying wastes. The silt loam layer acts as a medium for plant establishment and soil water storage, allowing more water to be recycled to the atmosphere by evapotranspiration. The PSB was designed with a storage capacity of $600 \mathrm{~mm}$ of water, which is more than 3 times the long-term average (LTA) precipitation for the Hanford Site.

Figure 1.1 shows a schematic cross section of the PSB and includes a depiction of the interactive water balance processes important to the successful performance of capillary barriers. The top 1-m layer is comprised of silt loam with a $15 \%$ by weight pea gravel admixture that increases its resistance to wind erosion. During deflationary periods, the concentration of pea gravel at the surface is expected to increase and form an armor as soil particles are removed by wind. During inflationary periods, a layer of soil that is largely free of pea gravel is expected to form on the surface (Ligotke 1994). The top $2 \mathrm{~m}$ of soil acts as a medium for plant establishment and water storage, allowing more water to be recycled to the atmosphere by evapotranspiration. At $2 \mathrm{~m}$, the silt loam-sand filter interface establishes a capillary break, which inhibits downward percolation of water and increases the storage capacity of the silt loam layer. The underlying layers are designed to limit plant and animal activity to the top layer, thereby minimizing bio-intrusion into the waste.

The low permeability composite asphalt layer $\left(\overline{\mathrm{K}}_{\mathrm{s}}=4.69 \times 10^{-10} \mathrm{~cm} \mathrm{~s}^{-1}\right)$ built with a $2 \%$ slope away from the center of the barrier, is the last line of defense to divert, from the waste zone, any water that might cross the capillary break. The asphalt layer is also intended to limit the upward movement of noxious gases from the waste zone and restrict root penetration. A series of curbs divide the surface of the asphalt layer into 12 water collection zones. The entire surface of the asphalt pad is covered with a layer of gravel to facilitate lateral drainage toward the lower slope positions of each collection zone and into a drainage monitoring system. Figure 1.2 is a schematic of the water collection zones. The 12 water collection zones (plots) include 8 main plots $(14 \mathrm{~m} \mathrm{x} 23 \mathrm{~m})$ and 4 transition plots $(4 \mathrm{~m} \mathrm{x} 23 \mathrm{~m})$. The transition plots separate the soil-covered plots from the rock and gravel-covered side slope plots. Four main plots $(4 \mathrm{~W}, 6 \mathrm{~W}, 6 \mathrm{E}, 4 \mathrm{E})$ and two transition plots $(5 \mathrm{~W}, 5 \mathrm{E})$ receive elevated precipitation at three times the LTA. The last four main plots $(1 \mathrm{~W}, 3 \mathrm{~W}, 3 \mathrm{E}, 1 \mathrm{E})$ and two transition plots $(2 \mathrm{~W}, 2 \mathrm{E})$ receive only natural precipitation. 


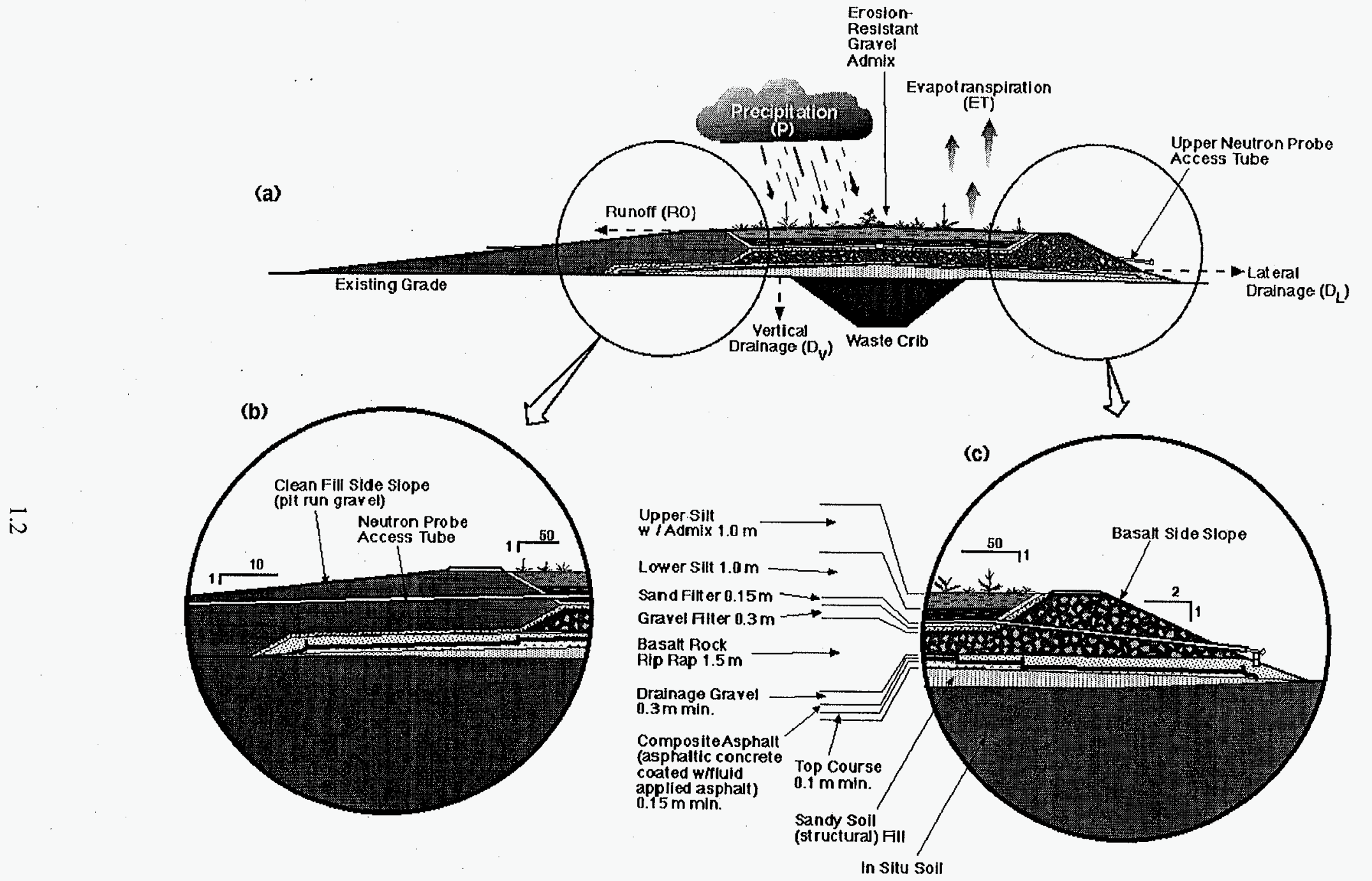

SP 97120037.2

Figure 1.1. Schematic of Hanford Barrier Showing Cross Sections. (Illustration [a] shows interactive water balance processes and barrier location relative to waste zone, [b] gravel side slope including horizontal neutron probe access tube and asphalt pad, and [c] basalt side slope, including horizontal neutron probe access tubes and asphalt pad.) 
During construction of the PSB, a series of U-shaped neutron probe access tubes was installed horizontally at different depths, above and below the asphalt pad, to permit monitoring of volumetric soil water content, $\theta$, at the capillary break and under the asphalt pad. At the western side of the PSB, a pair of access tubes was installed at $2 \mathrm{~m}$, near the soil-sand filter interface (AA1, AA2, AA3, AA4; Figure 1.2). A similar set of tubes (AA5, AA6, AA7, AA8) was installed on the eastern side. Each access tube was constructed from $76 \mathrm{~mm}$ i.d. aluminum tube and installed with the curved section toward the center of the barrier. Another three sets of tubes were installed under the northeastern section of barrier (BA1, BA2; Figure 1.2) at 1,2, and $3 \mathrm{~m}$ below the asphalt pad. The northeastern corner of the asphalt pad (under the northern buffer zone) was left uncurbed in order to quantify the amount of underflow that might occur with final barriers. A $6.5-\mathrm{m} \times 6.5-\mathrm{m}$ basin lysimeter was also installed beneath the asphalt pad (centered on plot $4 \mathrm{E}$ ) to permit infiltration monitoring through the asphalt pad.

The surface of the PSB is demarcated with a coordinate system established by a 3-m $\mathrm{x}$ 3-m grid (Figure 1.3). This grid was established by setting four corner markers to define a 36-m $\times 75-\mathrm{m}$ rectangle centered within the perimeter of the compacted gravel roadway. Each interior grid point is marked with a wooden survey stake numbered to identify the grid coordinate. A set of rock creep gauges was installed at 11 locations along the eastern rock protective slope. At each location, a creep gauge was installed at the midpoint of the slope, except for one location near the northeastern corner where two gauges (CG10a, CG10b) were installed at the upper and lower slope positions. Two differential settlement gauges were also installed at the northern end of the barrier on the top of the asphalt pad (Figure 1.3). To quantify barrier stability, the barrier is surveyed twice per year, using electronic distance measuring equipment (EDM) to determine surface elevation, creep gauge location, and elevation of the settlement gauges.

Three wind boundary layer stations (wind monitoring stations) were installed at the PSB to monitor wind stresses. Station 01 is located south of the center of the PSB surface and Station 02 is located in the southeast quadrant, near the rip rap side slope. In order to obtain measures of wind stresses over surfaces typical of the Hanford Site for comparison with the stress on the PSB, a third station, Station 03, was established on the PSB surface at the west south west corner of the site. Each station includes a wind direction sensor and four wind speed sensors, at elevations of $0.25 \mathrm{~m}, 0.50 \mathrm{~m}, 1.0$ $\mathrm{m}$, and $2.0 \mathrm{~m}$ above the soil surface.

The essential elements of testing and monitoring consist of testing the prototype under nonirrigated (natural precipitation) and irrigated (elevated precipitation)conditions. Each precipitation condition is referred to as a treatment. The irrigated treatment includes application of an extreme (1000yr) event in March of each test year and the total application (including precipitation) of $480 \mathrm{~mm} \mathrm{yr}^{-1}$ (3 times the LTA). To monitor the hydrologic performance of the PSB under different precipitation conditions, the surface of the PSB is fitted with 14 water balance monitoring stations, 7 on the northern side and 7 on the southern (non-irrigated side). On the irrigated treatment side, six stations were installed on the silt loam plots, three on $6 \mathrm{~W}(\mathrm{~S} 1, \mathrm{~S} 2, \mathrm{~S} 3)$ and three on $6 \mathrm{E}(\mathrm{S} 4, \mathrm{~S} 5, \mathrm{~S} 6)$. On the nonirrigated treatment, six stations were installed on the silt loam plots, three on $3 \mathrm{~W}(\mathrm{~S} 7, \mathrm{~S} 8, \mathrm{~S} 9)$ and three on $3 \mathrm{E}(\mathrm{S} 10, \mathrm{~S} 11, \mathrm{~S} 12)$. The remaining two stations (S13, S14) are located on the gravel side slope. No monitoring stations are located on the rock-covered slope. Each station is equipped with a precipitation meter to record precipitation events. Additional climatological data are obtained from the Hanford Meteorological Station (HMS), located about $5 \mathrm{~km}$ northwest of the PSB. 


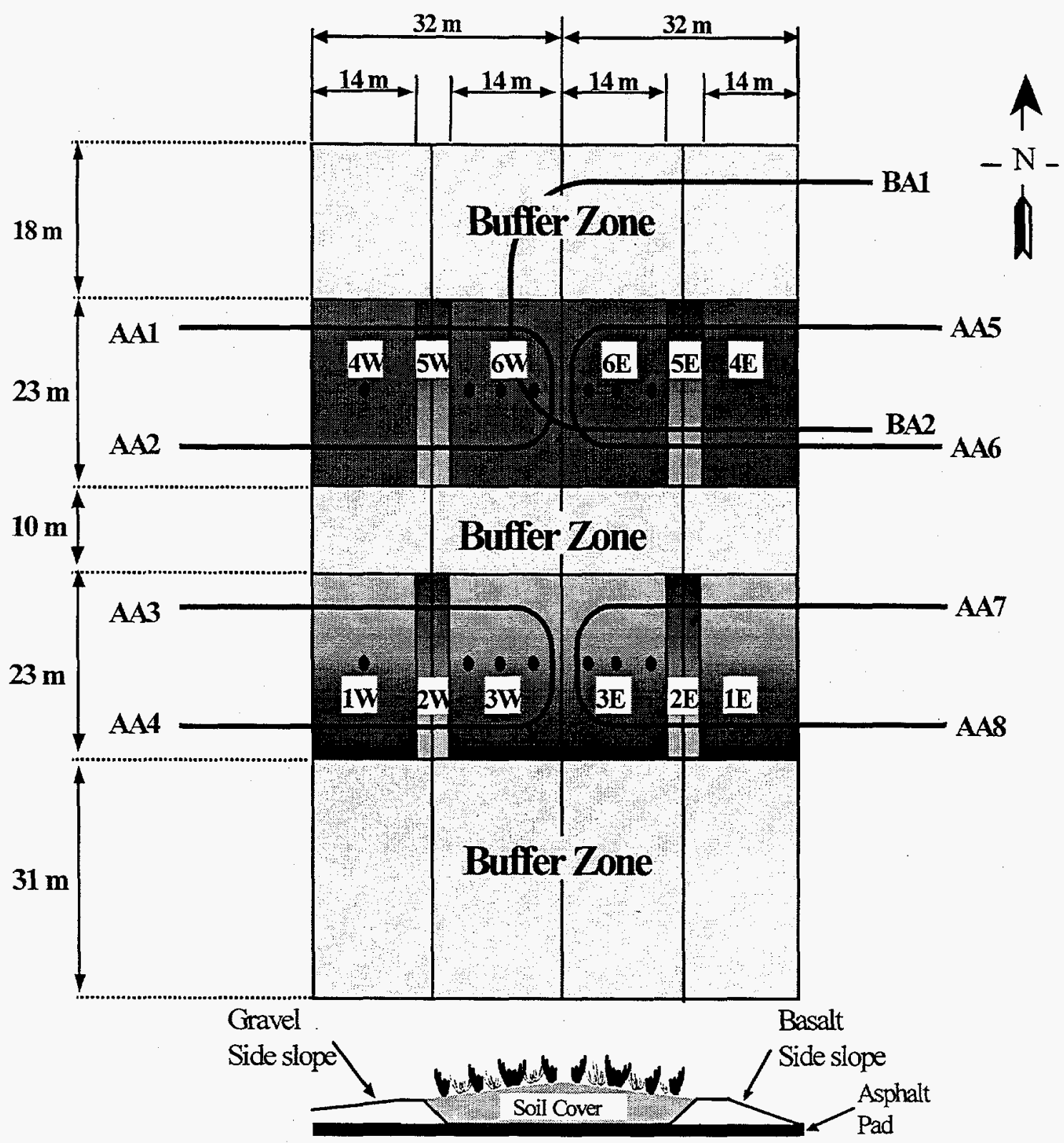

Figure 1.2. Plan View of the Prototype Surface Barrier Showing the Layout of the 12 Water Collection Zones on the Asphalt Pad. (Horizontal neutron probe access tubes are installed along eastern and western edges at the capillary break (2-m depth) and are shown as AA1 through AA8. A set of three horizontal access tubes are also installed under the asphalt pad at depths $1 \mathrm{~m}, 2 \mathrm{~m}$, and $3 \mathrm{~m}$ below the pad. BA1 and BA2 represent the two branches of the tube located $1 \mathrm{~m}$ below the asphalt.) 
Dosing Siphons (Drainage Monitors)

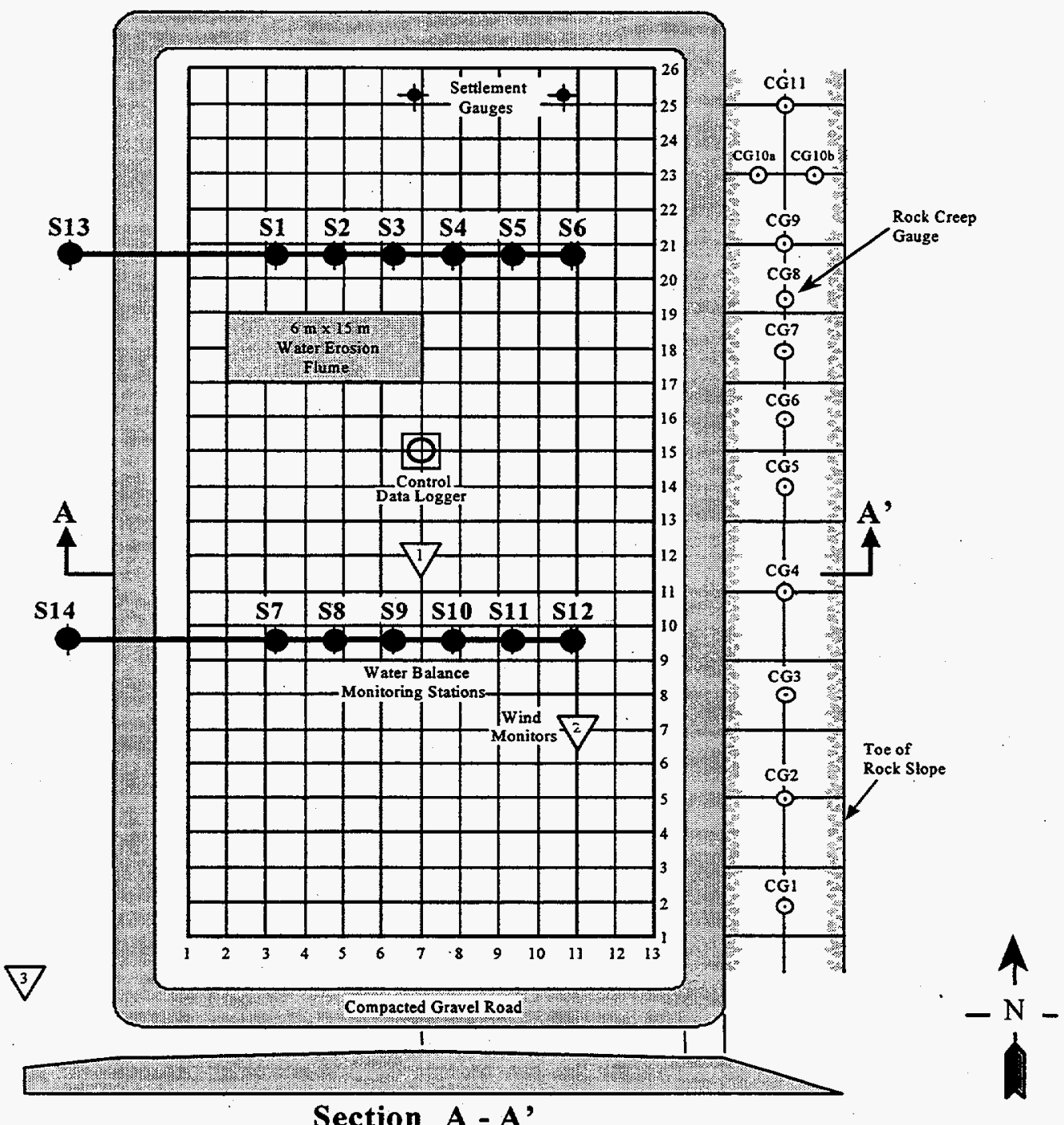

Figure 1.3. Plan View of the Barrier's Surface Showing the 3-m x 3-m Grid and Relative Positions of the Monitoring Stations. (Each of the 14 water balance monitoring stations includes access tubes for neutron and capacitance probes, a segmented TDR probe, a precipitation meter, and 7 HDU. Included are 3 wind monitoring stations; a water erosion flume; 11 creep gauges, and 2 settlement gauges. The 12 dosing siphons to the north monitor drainage. Cells 1-14 receive only natural precipitation. Cells $15-26$ are irrigated.) 
For measuring water content profiles in the top 2-m silt loam layer, each monitoring station is fitted with vertical access tubes for measurements with a Campbell Pacific Nuclear (model 503) neutron probe, a.PVC access tube for capacitance probe, and a $1.85-\mathrm{m}$ segmented time domain reflectometry TDR probe. Each station is also fitted with seven heat dissipation units (HDU) to measure soil temperature and matric potential, $\psi$. The HDUs are located at depths of $3.1 \mathrm{~cm}, 21.1 \mathrm{~cm}, 43.6 \mathrm{~cm}, 78.6$ $\mathrm{cm}, 123.6 \mathrm{~cm}$, and $173.6 \mathrm{~cm}$ from the surface.

Detailed measurement of the water balance components (including precipitation, irrigation, water storage, and drainage) are currently in process. Water erosion, wind erosion, and bio-intrusion parameters on the prototype barrier are also reported. Figure 1.4 summarizes the type of measurements and the data flow for the prototype testing. The expected precision for the various measurements is presented in Table 1.1. Figure 1.5 shows four aerial views of the completed prototype barrier, as it appeared immediately after construction in August 1994 and at yearly intervals since construction.

The testing and monitoring of the PSB is part of the DOE effort to provide performance data to the regulators and other interested stakeholders. The full-scale prototype protective barrier has allowed engineers and scientists to gain experience in barrier design, construction, and performance that is not acquired in any other way (Wing and Gee 1994; Gee et al. 1994, 1995; Petersen et al. 1995, Gee et al. $1996,1997)$. One objective of the prototype barrier design was to use natural materials to develop a PSB that isolates the waste site for at least $1000 \mathrm{yr}$ by limiting water, plant, animal, and human intrusion, and minimizing erosion.

Just how well the treatability test has performed in meeting design objectives still needs full evaluation; however the key aspects of the barrier performance appear satisfactory and are discussed in the following sections. Also discussed is how well the test objectives have been met. Specifically, this document summarizes work completed in FY 1997 on the prototype barrier and represents three years of testing. Water balance, water erosion, wind erosion, restoration, and bio-intrusion testing and monitoring activities are described in detail in Sections 2.0 through 5.0. Section 6.0 discusses all barrier issues. Section 7.0 describes quality assurance measures in use on the prototype barrier study. References are listed in Section 8.0 and a current list of barrier publications is provided in Section 9.0. 


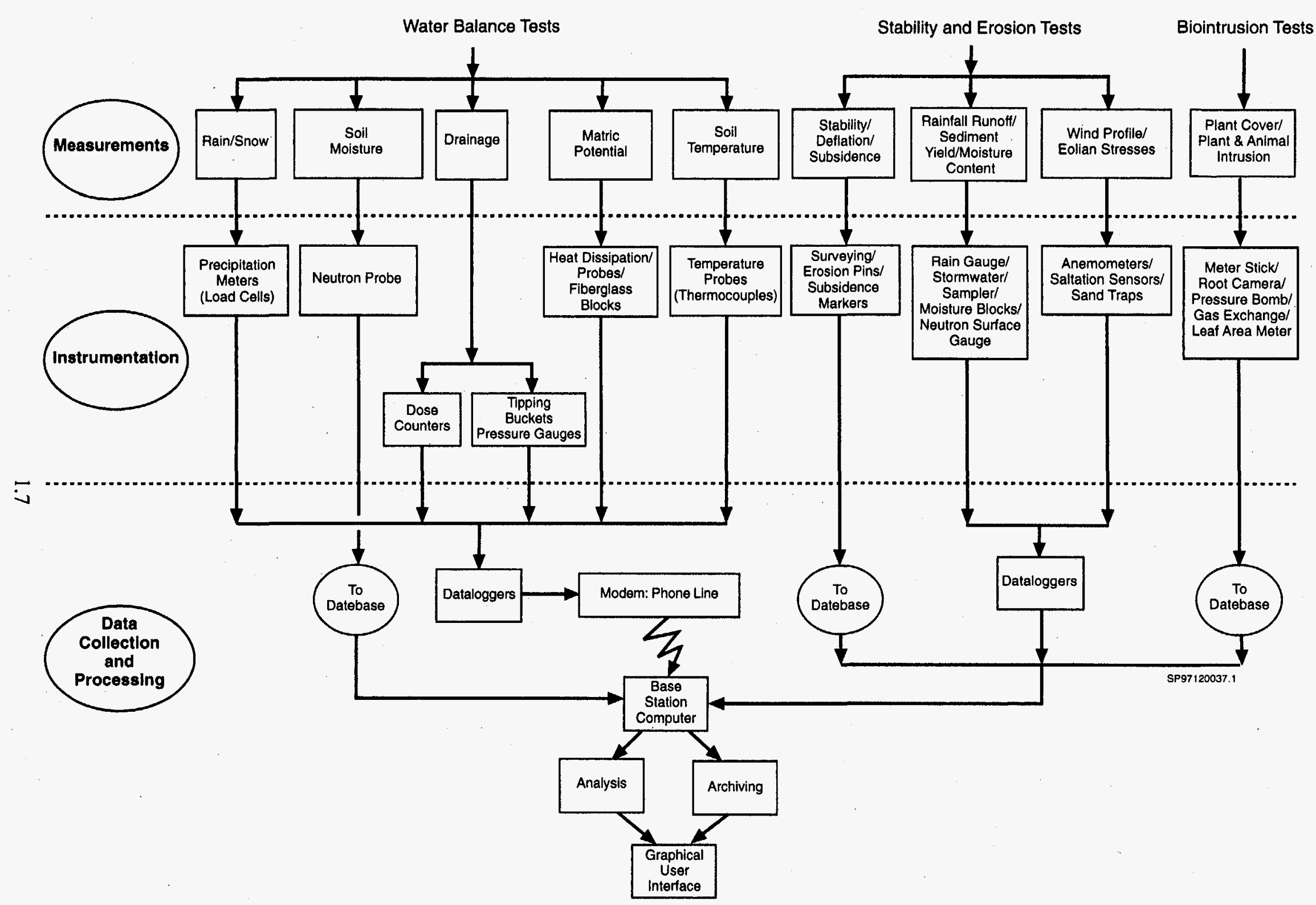

Figure 1.4. Measurement, Instrumentation, and Data Collection Flow Diagram for the Prototype Surface Barrier 
Table 1.1. Expected Measurement Precision for Water Balance, Stability, and Biointrusion Monitoring at the Prototype Surface Barrier.

\begin{tabular}{|c|c|c|c|}
\hline Variable & Measurement Method & Resolution & Expected Precision \\
\hline Precipitation (mm) & tipping bucket gauge & $\pm 0.25 \mathrm{~mm}$ & $\pm 0.25 \mathrm{~mm}$ \\
\hline Irrigation (mm) & $\begin{array}{l}\text { load cells } \\
\text { manual rain gauges }\end{array}$ & $\pm 0.2 \mathrm{~mm}$ & $\pm 0.2 \mathrm{~mm}$ \\
\hline Matric potential $\left(\mathrm{J} \mathrm{kg}^{-1}\right)$ & heat dissipation units & $\pm 10 \mathrm{~J} \mathrm{~kg}^{-1}$ or less & $\begin{array}{l}95 \% \text { confidence interval } \\
\text { of calibration curve }\end{array}$ \\
\hline Soil temperature $\left({ }^{\circ} \mathrm{C}\right)$ & $\mathrm{Cu}-\mathrm{Co}$ thermocouples & $\pm 0.008^{\circ} \mathrm{C}$ & $\pm 0.01{ }^{\circ} \mathrm{C}$ \\
\hline Water storage $(\mathrm{mm})$ & $\begin{array}{l}\int \theta(z) d z ; \theta \text { measured } \\
\text { from surface to depth } L \\
\text { by neutron probe }\end{array}$ & $\pm 0.005 \mathrm{~m}^{3} \mathrm{~m}^{-3}$ & $\begin{array}{l} \pm 9.5 \mathrm{~mm} \text { over depth } \mathrm{L} \\
\text { subject to confidence } \\
\text { interval of calibration } \\
\text { curve }\end{array}$ \\
\hline Surface runoff (mm) & ISCO flow meter & $\pm 0.25 \mathrm{~mm}$ & $\pm 0.25 \mathrm{~mm}$ \\
\hline Drainage (mm) & $\begin{array}{l}\text { tipping bucket gauge } \\
\text { pressure transducer }\end{array}$ & $\begin{array}{l} \pm 0.025 \mathrm{~mm} \\
\pm 0.025 \mathrm{~mm}\end{array}$ & $\begin{array}{l}\text { main plot: } 3.52 \times 10^{-5} \mathrm{~mm} \\
\text { trans plot: } 7.04 \times 10^{-5} \mathrm{~mm} \\
\pm 0.26 \mathrm{~mm} \mathrm{yr}^{-1} \text {; controlled } \\
\text { by seepage through walls } \\
\text { of vault }\end{array}$ \\
\hline $\begin{array}{l}\text { Evapotranspiration } \\
(\mathrm{mm})\end{array}$ & $\begin{array}{l}\text { by difference; } \\
\mathrm{ET}=(\mathrm{P}+\mathrm{I})-(\Delta \mathrm{S}+\mathrm{R}+\mathrm{D})\end{array}$ & $\begin{array}{l}\text { set by least precise } \\
\text { component, } \Delta S\end{array}$ & $\pm 9.5 \mathrm{~mm}$ \\
\hline Subsidence/Elevation & $\begin{array}{l}\text { Electronic Distance } \\
\text { Measurement }\end{array}$ & $\pm 1 \mathrm{~mm}$ over $1 \mathrm{~km}$ & $\pm 0.05 \%$ of distance \\
\hline $\begin{array}{l}\text { Gravimetric water } \\
\text { content ( } \mathrm{g} \text { of water per } \mathrm{g} \\
\text { of dry soil) }\end{array}$ & $\begin{array}{l}\text { mass of soil core } \\
\text { before and after oven } \\
\text { drying }\end{array}$ & $\pm 0.01 \mathrm{~g} \mathrm{~g}^{-1}$ & $\begin{array}{l}\text { subject to spatial } \\
\text { variability }\end{array}$ \\
\hline Soil bulk density & $\begin{array}{l}\text { mass of oven-dried soil } \\
\text { in core of known size }\end{array}$ & $\pm 0.05 \mathrm{~g} \mathrm{~cm}^{-3}$ & $\begin{array}{l}\text { subject to spatial } \\
\text { variability }\end{array}$ \\
\hline $\begin{array}{l}\text { Pea gravel content ( } \mathrm{g} \text { of } \\
\text { gravel per } \mathrm{g} \text { of soil) }\end{array}$ & $\begin{array}{l}\text { mass of gravel in core } \\
\text { of known size }\end{array}$ & $\pm 0.01 \mathrm{~g} \mathrm{~g}^{-1}$ & $\begin{array}{l}\text { subject to spatial } \\
\text { variability }\end{array}$ \\
\hline Wind speed & anemometer & $\pm 0.15 \mathrm{~m} \mathrm{~s}^{-1}$ & $\pm 0.15 \mathrm{~m} \mathrm{~s}^{-1}$ \\
\hline $\begin{array}{l}\text { Plant height, rooting } \\
\text { depth; animal } \\
\text { burrowing depth }\end{array}$ & meter stick & $\pm 1.0 \mathrm{~mm}$ & $\pm 0.1 \%$ of length \\
\hline Plant mass & Laboratory balance & $\pm 0.01 \mathrm{~g}$ & $\pm 0.01 \mathrm{~g}$ \\
\hline
\end{tabular}


('L66[ нәquәңdəS

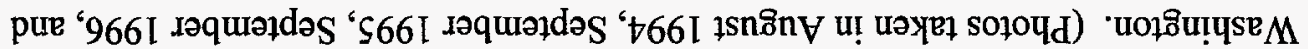

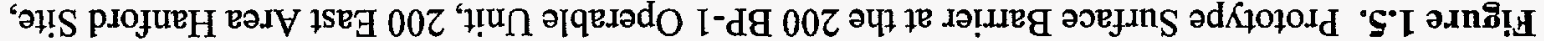

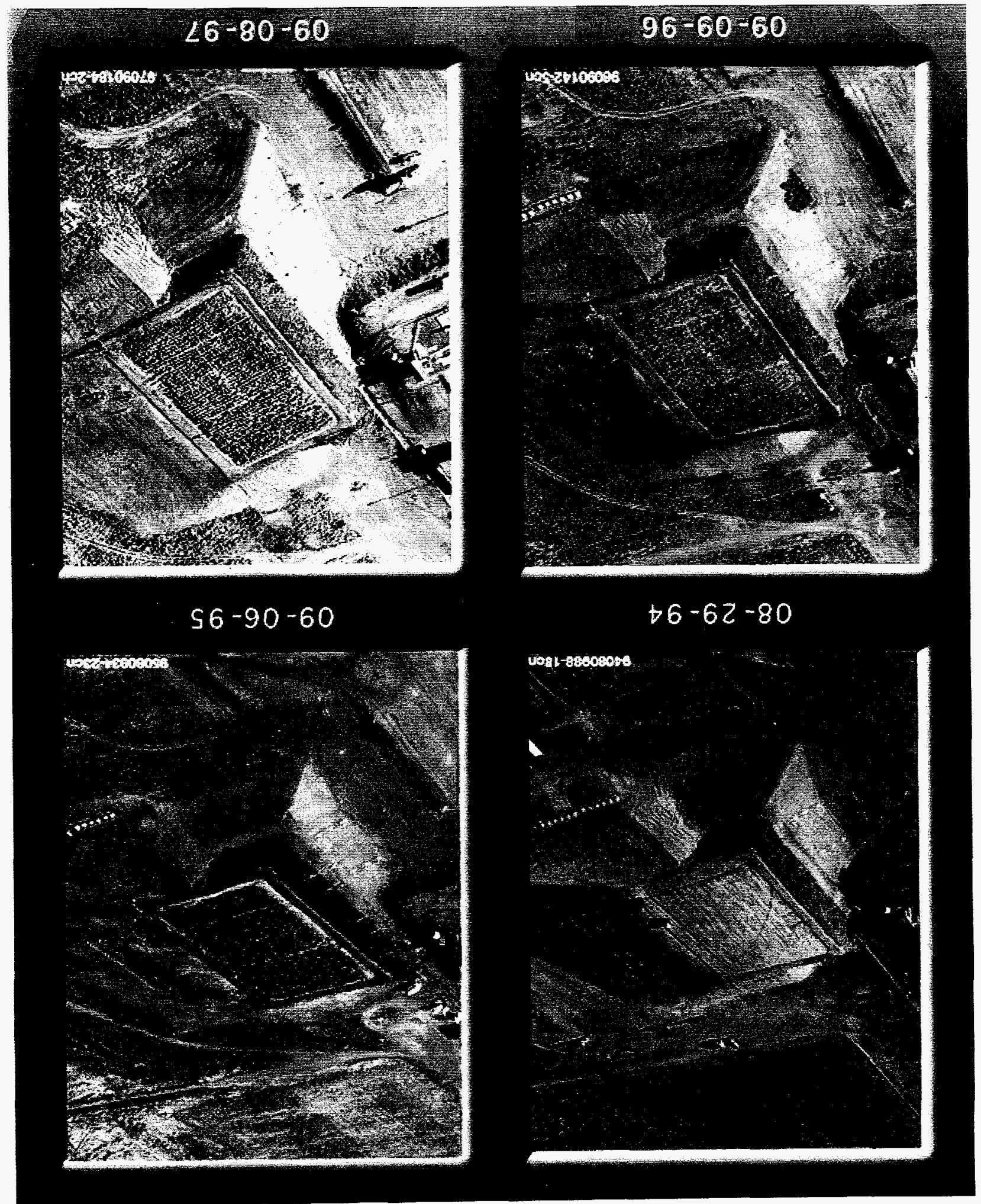




\subsection{Water Balance Evaluation}

When deployed for waste isolation, surface barriers are intended to serve several key functions. The primary function is to minimize infiltration of water to the buried waste or contaminated soil and the subsequent leaching of contaminants. At semiarid sites, successful performance of this primary function is dependent on the operation of a series of interactive and dynamic processes that govern the water balance. Apart from the diversion of onsite water away from the waste zone, important processes include enhancing water storage and natural processes such as evapotranspiration (ET). An evaluation of the soil water balance for waste covers is, therefore, the most accurate and comprehensive approach to quantifying performance. Over the last three years, the Water Balance task has focused on collecting data from a prototype Hanford barrier that will permit performance evaluation of this barrier and other barriers of similar configuration. This section summarizes the results on the Water Balance task (formerly referred to as the Water Infiltration Control task) for the third year of testing and monitoring at the prototype barrier.

\subsection{Scope and Objectives}

Prior to construction of the prototype surface barrier (PSB), the Field Lysimeter Test Facility (FLTF) was used to quantify water movement in and through various barrier configurations, under normal and elevated precipitation conditions. The FLTF is located about $5 \mathrm{~km}$ northwest of the PSB. Although the resulting data provided invaluable information on the effectiveness of various barrier designs and on the performance of individual components, they could not be used to predict field-scale performance of a fully integrated barrier. This is because the FLTF is unable to capture effects of scale and multidimensionality of a field-scale barrier. The scope of this task is to quantify the water balance components (precipitation, surface runoff [RO], water storage, drainage, and ET). This effort would assess the effectiveness of the Hanford PSB in controlling recharge to underlying wastes. Two major issues identified in the Treatability Test Plan for the 200-BP-1 Prototype surface barrier are evaluating: 1) the effects of extreme precipitation events on water infiltration, and 2) the effects of water infiltration on side slope stability and subsurface water content (Gee et al. 1993; DOE 1993). The primary objective of the Water Balance task is to demonstrate the protective barrier is capable of controlling infiltration through the surface to the waste zone underneath. Resolution of the major issues and meeting the primary objective are best achieved through a water balance evaluation approach.

\subsection{Water Balance Testing and Monitoring Activities}

In many circumstances, a balance sheet of water losses (by evaporation, transpiration, RO, and drainage) and water gains (by precipitation and irrigation) can be successfully developed, provided the amount of transpiration and evaporation can be determined. Various techniques have been developed for calculating water loss from soil by ET using data from meteorological studies. Apart from the use of 
weighing lysimeters, which provide the most accurate approach for measuring ET, reliable ET estimates can also be obtained from the water balance, if the other components can be measured. A simplified form of the water balance equation to evaluate ET may be written as

$$
E T=(P+I)-(\Delta S+R+D)
$$

where

ET = evapotranspiration

$\Delta \mathrm{S} \quad=$ change in soil water storage

$\mathbf{P} \quad=$ natural precipitation

I $\quad=$ irrigation

$\mathrm{RO}=$ surface runoff

D $\quad=$ drainage from the soil profile.

The change in storage, $\Delta S$, between times $t_{1}$ and $t_{2}$, is calculated as

$$
\Delta S=\int_{0}^{L} \int_{t_{1}}^{t_{2}} \frac{\partial \theta(z, t)}{\partial t} d z d t
$$

where $z$ is the depth in the soil profile, $L$ is the maximum depth to which the volumetric water content, $\theta$, is measured, $t$ is time and time $t_{2}$ is greater than $t_{l}$. Over the last three years, work has focused on testing and monitoring activities to quantify the water balance components. The results of these activities are summarized in the following categories, 1) Water Inputs, 2) Soil Water Storage, 3) Infiltration and Drainage, and 4) Evapotranspiration.

\subsubsection{Water Inputs}

This year, for the first time, the end of the Water Year (WY) was advanced to September 30, 1997 to coincide with the end of the Fiscal Year (FY). Climatic data from the Hanford Meteorological Station (HMS) show that 1997 was the second wettest year on record in 50 years. The winter months (December 1996, January 1997, and February 1997) produced $138 \mathrm{~mm}$ of precipitation compared to the normal $61 \mathrm{~mm}$, making it the wettest winter ever recorded at Hanford. The total precipitation recorded at the Hanford Site in WY-1997 (November 1, 1996 through October 31, 1997) was $291.6 \mathrm{~mm}$, almost twice the normal $160 \mathrm{~mm}$.

Figure 2.1 shows a plot of cumulative precipitation over the last three years, as well as the long-term average (LTA) and elevated precipitation target. The total amount of water applied to the barrier in WY1997 was $504.1 \mathrm{~mm}, 24.1 \mathrm{~mm}$ above the scheduled $480 \mathrm{~mm}$. Over the last three WY, the total amount of precipitation received by the irrigated treatment was $1485.7 \mathrm{~mm}$, compared to $812.8 \mathrm{~mm}$ received by the non-irrigated treatment. The total amount of irrigation water applied was $672.9 \mathrm{~mm}$. 


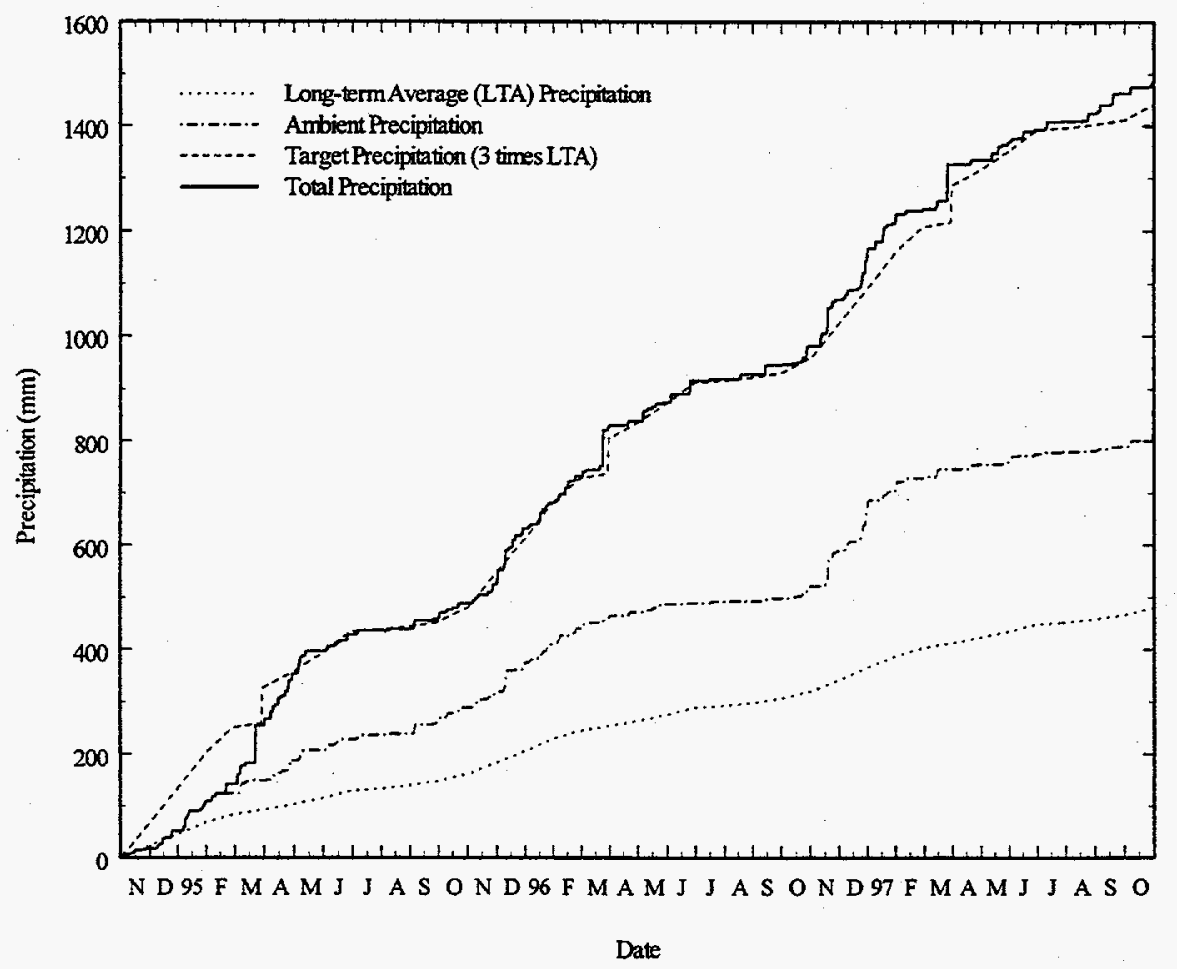

Figure 2.1. Cumulative 3-Year Precipitation Data for Barrier Testing and Monitoring.

The non-irrigated tests were conducted at precipitation levels greater than the LTA. In WY-1997, the precipitation received by the non-irrigated treatment on the PSB was 1.8 times higher than the LTA, compared to 1.5 times in WY-1996 and 1.8 times in WY-1995. Thus, water balance data from the nonirrigated treatments of the PSB should provide a conservative measure of hydrologic performance under non-irrigated conditions.

\subsubsection{Soil Water Storage}

In WY-1997, neutron probe readings generally were taken twice per month, except immediately after the 1000 -yr storm when the frequency was doubled. Measurements were taken at $0.15-\mathrm{m}$ increments from the surface and the data were stored electronically. Neutron probe counts were converted to volumetric soil water contents as a function of depth and time, $\theta(z, t)$, using the calibration derived for the prototype barrier (Gee et al. 1996). Measured $\theta(z, t)$ were used to derive soil water storage, $S$, as well as changes in storage, $\Delta S$, in the silt-loam plots. 


\subsubsection{Temporal Trends in Storage}

Figure 2.2 presents a 3-year summary of $\mathrm{S}$ for the silt loam plots. In general, the temporal trend in $\mathrm{S}$ was independent of precipitation treatment. Both treatments showed an annual cycle in $\mathrm{S}$ that reached a maximum storage in mid-February to early March and a minimum by the end of October each year. To a large extent, this trend is controlled by the vegetation on the barrier surface. During the winter months, the main mechanisms for water loss - transpiration and evaporation - are not operational and essentially, the barrier must store all of the precipitation intercepted. Thus, storage is at a maximum when winter ends in February. The increase in surrounding temperature and the onset of plant transpiration leads to a rapid decline in storage. Although evaporation might have played an important role in WY-1995, the contribution is now quite small because the entire surface of the barrier is covered with vegetation.
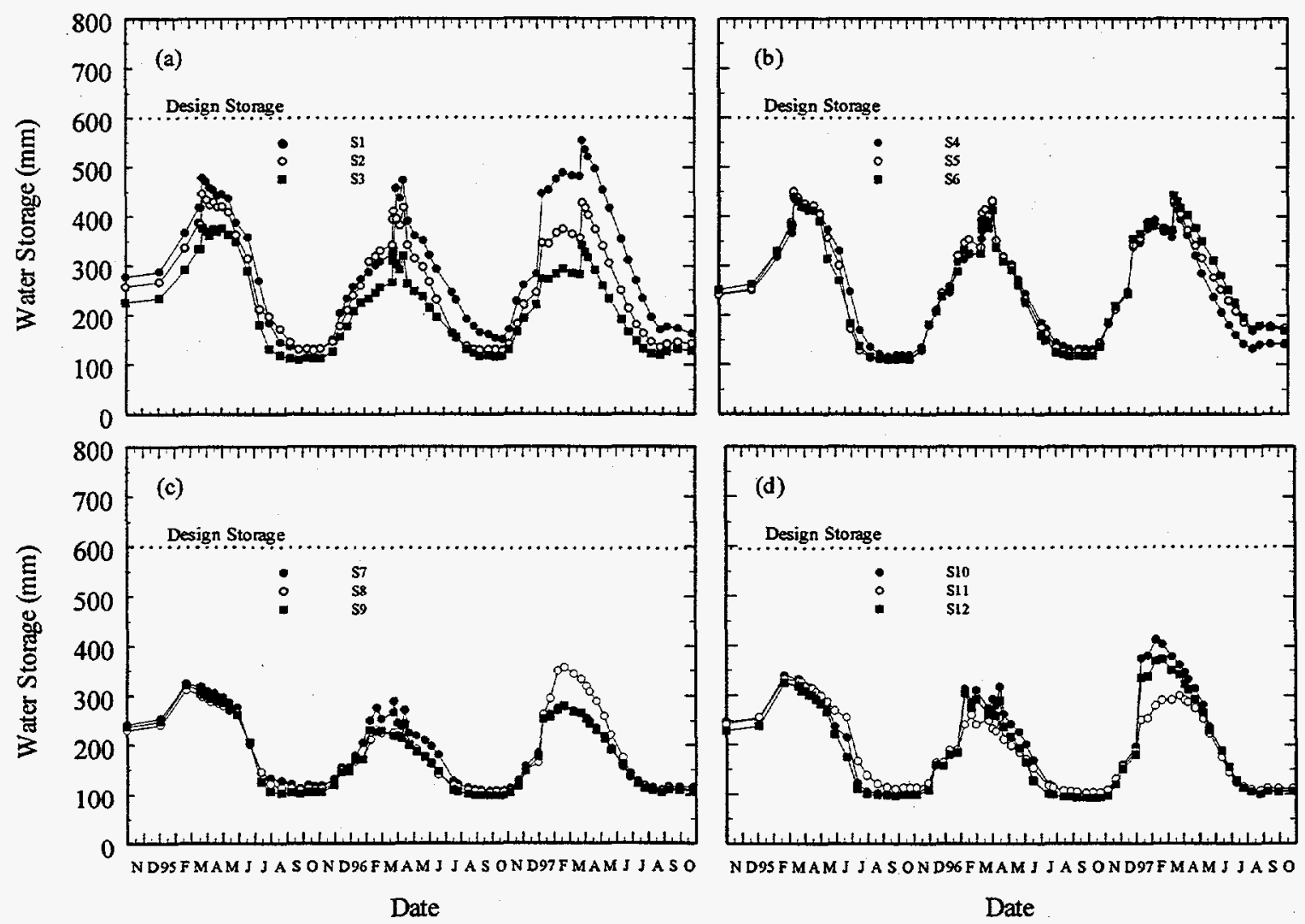

Figure 2.2. Temporal Variation in Soil Water Storage at the Barrier November 1994 - October 1997. ([a] northwest irrigated plot, [b] northeast irrigated plot, [c] southwest non-irrigated plot, and [d] southeast non-irrigated plot.) 


\subsubsection{Storage Minima and Maxima}

The value of $S$ always shows a strong dependence on precipitation treatment, never exceeding $350 \mathrm{~mm}$ on the non-irrigated treatment and $500 \mathrm{~mm}$ on the irrigated treatment. This trend was changed in WY-1997. During the winter months, $S$ on the northwest irrigated plot (Figure 2.2a) exceeded the maxima of previous years, although northeast irrigated plot showed no change (Figure 2.2b). Both nonirrigated plots, the southwest (Figure 2.2c) and the southeast (Figure 2.2d), showed large increases in $S$ in the winter months. The increase in $S$ on the northwest and southeast plots was caused by water which accumulated as a result of snowmelt and surface $\mathrm{RO}$ in these areas.

The maximum and minimum storage observed each year are important indicators of barrier performance. Over time, changes in the maxima or minima indicate changes in the ability of the barrier to store and recycle water. The storage data were analyzed to determine the maximum $\left(\mathrm{S}_{\max }\right)$ and minimum $\left(\mathrm{S}_{\min }\right)$ values of $S$ observed during the last three years. The mean $S_{\max }$ on the irrigated treatment in 1997 was $437 \pm 63 \mathrm{~mm}$, which was not significantly different from the $415 \pm 44 \mathrm{~mm}$ observed in WY1996. On the non-irrigated treatment, the mean $S_{\max }$ in 1997 was $333 \pm 51 \mathrm{~mm}$, which was not significantly different from the $276 \pm 29 \mathrm{~mm}$ observed in 1996 . To date, the $600-\mathrm{mm}$ storage capacity has never been exceeded. The mean $\mathrm{S}_{\min }$ in WY-1997 was $122 \pm 20 \mathrm{~mm}$, compared to $114 \pm 16 \mathrm{~mm}$ in $W Y-1996$ and $112 \pm 9 \mathrm{~mm}$ in WY-1995. On the irrigated treatment, $S_{\min }$ values were $117 \pm 9 \mathrm{~mm}$ in WY-1995, $127 \pm 12 \mathrm{~mm}$ in WY-1996, and $139 \pm 16 \mathrm{~mm}$ in WY-1997. On the non-irrigated treatment, $S_{\min }$ values were $106 \pm 6 \mathrm{~mm}$ in WY-1995, $102 \pm 5 \mathrm{~mm}$ in WY-1996, and $106 \pm 4 \mathrm{~mm}$ in WY-1997. No significant differences in $\mathrm{S}_{\min }$ were observed between treatments within individual years, or between years, and the variance in $S_{\min }$ remained essentially unchanged. The higher variance in $S_{\min }$ on the irrigated plots and its increase over time may be a reflection of the spatial variability in water application. However, most of the variance is due to the northwest irrigated plot $(6 \mathrm{~W})$, suggesting some factor other than water application.

\subsubsection{Spatial Dependence of Storage}

Soil water storage shows no clear dependence on spatial position, except on the northwest (6W) irrigated plot (Figure 2.2a). There, the amount of storage appears negatively correlated with the location of the access tube along the sloped $(2 \%)$ surface, declining in value as the crown is approached. Tube $\mathrm{Sl}$, which is $7 \mathrm{~m}$ from the northwestern edge of the barrier, has shown consistently higher values of $\mathrm{S}$ than $\mathrm{S} 2$ and $\mathrm{S} 3$, which are $13 \mathrm{~m}$ and $17 \mathrm{~m}$ from the edge, respectively. Tube $\mathrm{S} 3$ has consistently shown $\mathrm{S}$ values similar to those observed on the non-irrigated plots and has never exceeded $400 \mathrm{~mm}$. The spatial dependence may be due to one of two factors, or a combination of both. First, the disparity in $S$ could be due to differences in the amount of water received along the slope of the plot. The soil surface slopes away from S3, and over the last three years, snow drifts and surface RO have often accumulated along the northwestern edge (near S1). For example, in the winter of WY-1997, snow depth exceeded $60 \mathrm{~cm}$ near S1, but was less than $30 \mathrm{~cm}$ on the crown of the barrier ( $2 \mathrm{~m}$ from S3). Although the different snow depths may explain the increased disparity during the winter months, it does not explain the consistent difference over the years. 
Much of the disparity could arise from spatial variability of bulk density. During construction, soil was brought to northwestern edge and then spread to the other regions with heavy machinery. This activity could have led to a gradation in bulk density away from the edge. During instrument installation, this area was more difficult to core than the rest of the barrier (Ritter 1994, personal communication). Where a linear calibration is assumed for a soil at constant bulk density, the functional relationship between neutron counts, $n$, (not corrected for density) and $\theta$ is curvilinear and negatively correlated (Greacen and Hignett 1979). At present, a single neutron calibration curve is used to infer $\theta$ from $n$ without a density correction. Thus, it is quite possible that water storage is currently underestimated. Efforts are currently underway to obtain data on the spatial variability of bulk density and the $\theta(n)$ relationship to allow validation of the current calibration.

\subsubsection{Infiltration and Drainage}

In the context of this report, infiltration refers to water that leaves the fine-soil layer (0-2 $\mathrm{m})$ and accumulates at, or crosses, the capillary break. If the water potential approaches atmospheric pressure, the capillary break could be compromised, water could move down to the asphalt layer and be diverted to the drainage monitoring system. Under certain conditions, particularly failure of the asphalt layer, some of this water could penetrate the asphalt, moving into the below-asphalt pan lysimeter and changing the $\theta$ beneath the asphalt layer. Changes in $\theta$ at the capillary break and under the asphalt are monitored using the neutron probe through horizontal neutron access tubes. In FY-1997, monitoring of $\theta$ at the capillary break was done twice per month, coinciding with the silt loam vertical measurements. The below-asphalt measurements were taken once per month. The results of these activities are summarized in the following paragraphs.

\subsubsection{Horizontal Silt-Ioam Measurements}

Figure 2.3 shows plots of water content as a function of space and time, $\theta(x, t)$, under the PSB irrigated treatment (AA1 and AA2) from November 1994 through October 1997. The $x$-axis represents horizontal distance from the center of the barrier, with a positive ordinate to the east of center (toward the basalt side slope) and a negative ordinate to the left of center (toward the gravel side slope). Over the last three years, water accumulation showed a clearly defined cycle, with $\theta$ increasing in the winter, reaching a maximum in late spring, and decreasing over the summer. In all three years, the greatest accumulation of water occurred under the transition zones (plots $5 \mathrm{~W}$ and $5 \mathrm{E}$ ) of the prototype. Because of the fine that covers the coarse soil sequence at the sloped interface, the interface acts like a capillary break, forcing water to infiltrate downward to the bottom of the soil layer, rather than draining over the side slope. The smaller buildup of water at the west side (sloped silt-gravel interface) suggests less infiltration may have occurred than on the east side (slope silt-basalt interface). This mechanism could impact long-term performance, leading to more extensive lateral migration along the capillary break in wetter years. Water content along the capillary break was fairly consistent in the first year, but has shown more spatial variability in subsequent years. Lateral migration of moisture in the northeast section was significant last winter with $\theta$ exceeding $0.30 \mathrm{~m}^{3} \mathrm{~m}^{-3}$ at several points along the capillary break. 
(a)

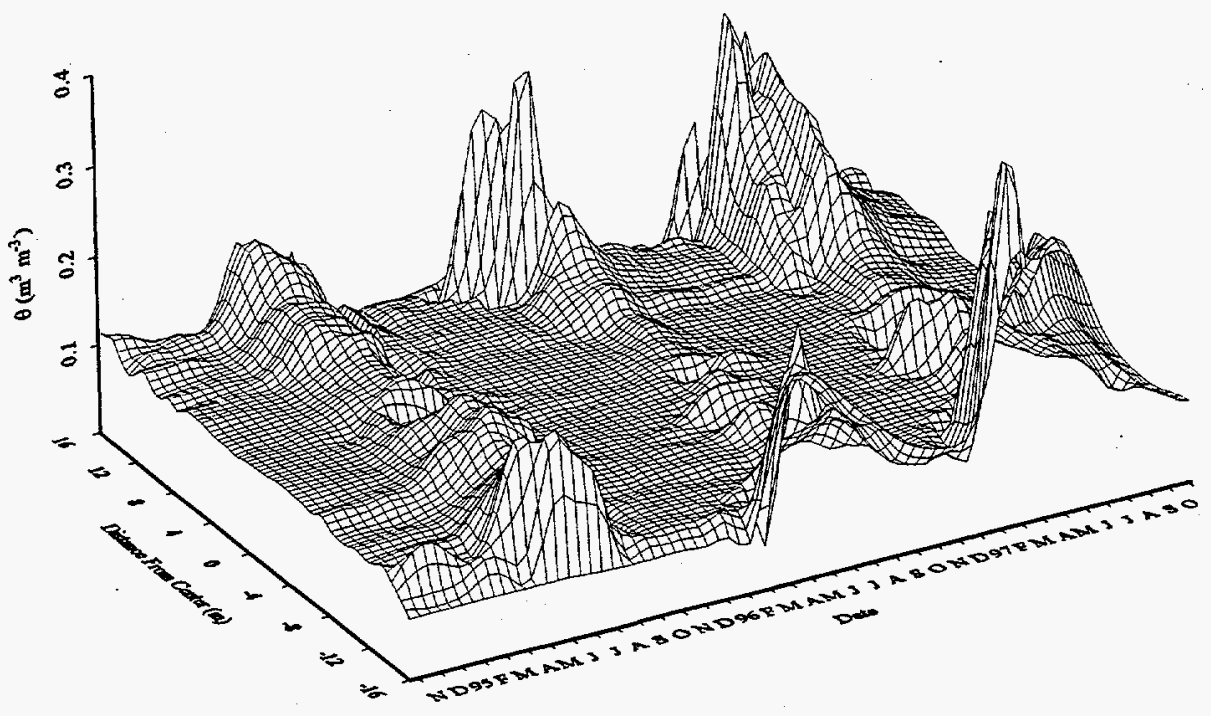

(b)

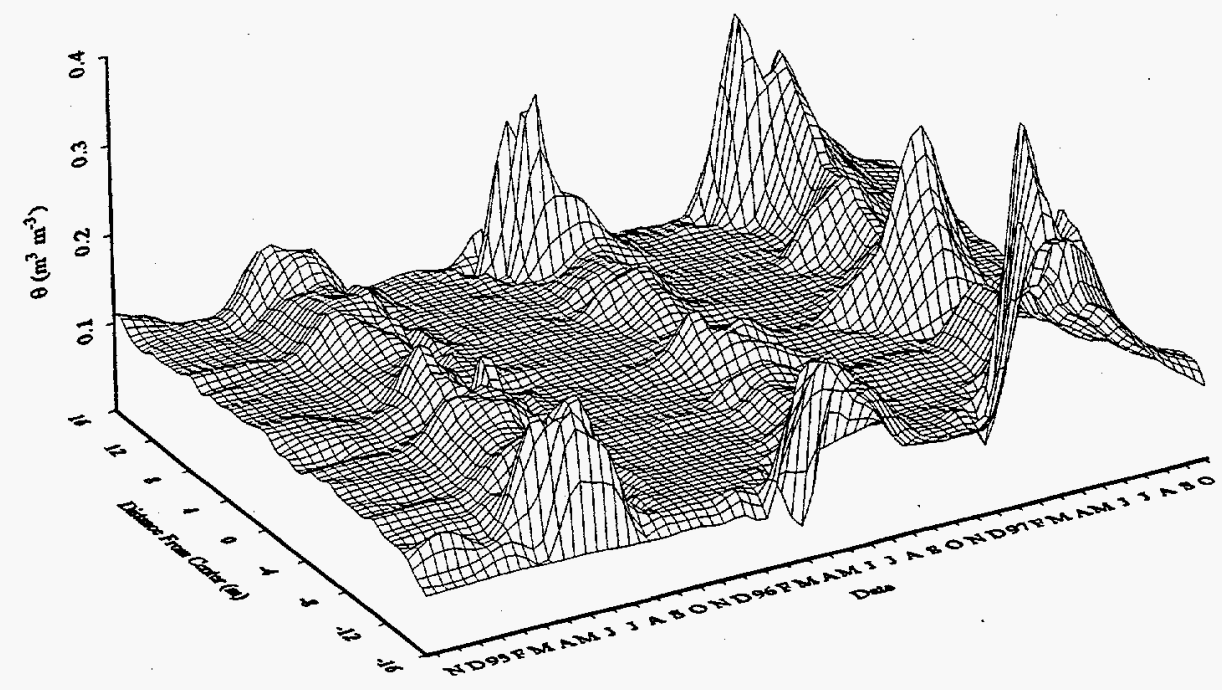

Figure 2.3. Spatial/Temporal Variations in Soil Water Content at Capillary Break - Irrigated Treatment. ([a] north end of treatment, tube AAl, and [b] south end of treatment, tube AA2.) 
Figure 2.4 shows $\theta(\mathrm{x}, \mathrm{t})$ under the non-irrigated treatment (AA3 and AA4) of the PSB from November 1994 through October 1997. The coordinate system is identical to that previously described. During then first two years, no increase was noted in $\theta$ at the capillary break of the non-irrigated treatment. In fact, $\theta$ decreased within the first few months of surface re-vegetation and remained unchanged throughout most of the test period. This trend showed a dramatic change in WY-1997 when infiltration from melting snow drifts in the southeastern corner led to a large increase in $\theta$. An increase in $\theta$ also occurred on the southwest, although the change was much smaller.

To gain a better visual perspective of the temporal change in $\theta$, two transects were extracted from these data to generate 2-dimensional plots of $\theta(\mathrm{t})$ at $7 \mathrm{~m}$ (midpoint of the plot) and $14 \mathrm{~m}$ (outer edge of the plot) in each treatment. These data are presented in Figure 2.5. In November 1994, initial $\theta$ on the four plots was relatively similar, with a mean of $0.10 \mathrm{~m}^{3} \mathrm{~m}^{-3}$ over all plots. Despite regular irrigations, no significant increase in $\theta$ was found at the capillary break until just after the first simulated 1000 -yr storm on March 26, 1995. In general, $\theta$ at the capillary break starts to decrease within a month of reaching its maximum value. The difference in the arrival time of the wetting front on tubes at the north and south ends of each plot, and between the value of $\theta$ on the west (Figure 2.5a) and east (Figure 2.5b) plots is most likely due to a difference in the snow and water accumulation during the winter and spring. Accumulation of water during the winter months and after the simulated 1000-yr storm was highest at the northwest and northeast edges of the irrigated plots (tubes AA1 and AA6).

Figures $2.5 \mathrm{c}$ and Figure $2.5 \mathrm{~d}$ show the large change in $\theta$ on the non-irrigated plots that occurred for the first time in FY-1997. Water content reached as high as $0.30 \mathrm{~m}^{3} \mathrm{~m}^{-3}$, which corresponds to a matric potential of about $-186 \mathrm{~cm}$ of water. The saturated $\theta$ for the Warden silt loam is $0.49 \mathrm{~m}^{3} \mathrm{~m}^{-3}$. By the end of September, $\theta$ had been reduced to pre-winter levels, consistent with the water storage data for the silt loam. Such a dramatic reduction in $\theta$ is most likely due to plant water uptake and transpiration. The horizontal $\theta(x, t)$ data show that accumulation of water at the base of the silt loam profile generally can be controlled. However, in extremely wet winters like the last one, accumulation of water at the base of the sloped interface could cause an increase in the matric potential to a point where water could cross the capillary break. Water crossing the capillary break would eventually be diverted by the asphalt layer to the drainage monitoring system. Because neutron probe measurements at the capillary break will be biased toward a lower $\theta$ by the coarse-textured soils, $\theta$ is not an accurate indicator of the drainage potential. The most accurate measurement tool for the drainage condition is a tensiometer, or some other device that measures matric potential. In the absence of such sensors in the capillary break, the most accurate way of recognizing this condition is through monitoring water that is diverted by the asphalt layer. Drainage data are presented in the following section.

\subsubsection{Drainage}

One of the most important task objectives was to demonstrate barrier effectiveness in limiting recharge to the waste zone to $0.5 \mathrm{~mm} \mathrm{yr}^{-1}$ or less. Another important objective was to investigate and document the factors influencing performance of two side slope configurations at the PSB. Ultimately, both of these objectives can be reached by monitoring the amount of water diverted by the asphalt layer. In the context of this report, drainage refers to the water diverted by the asphalt layer. 
(a)

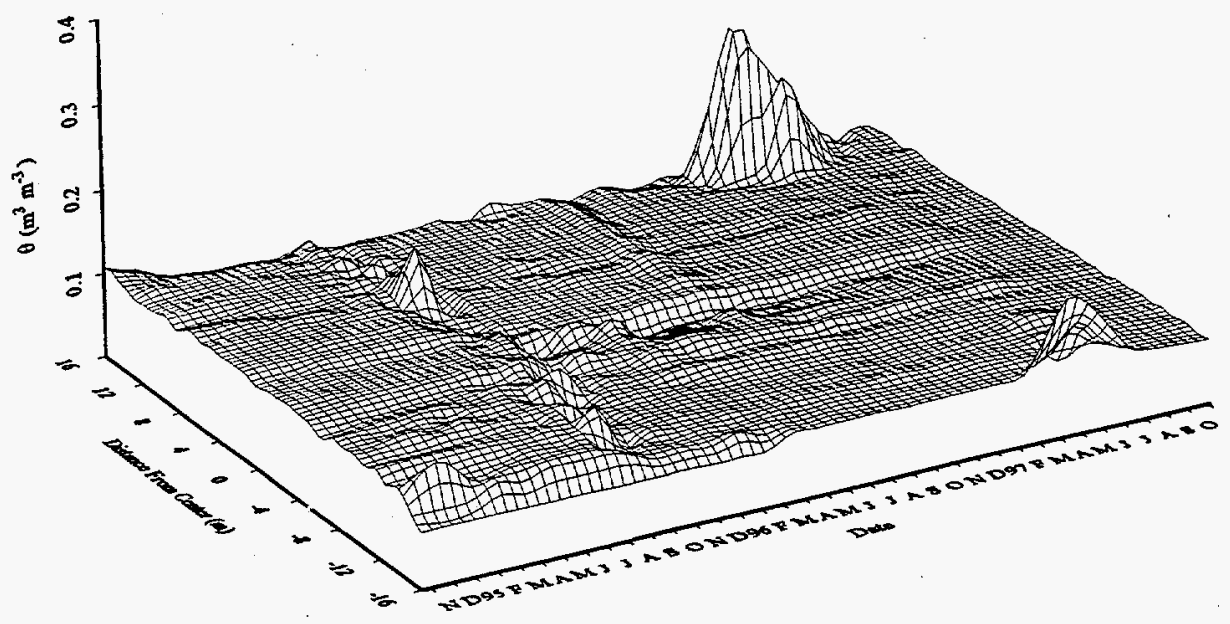

(b)

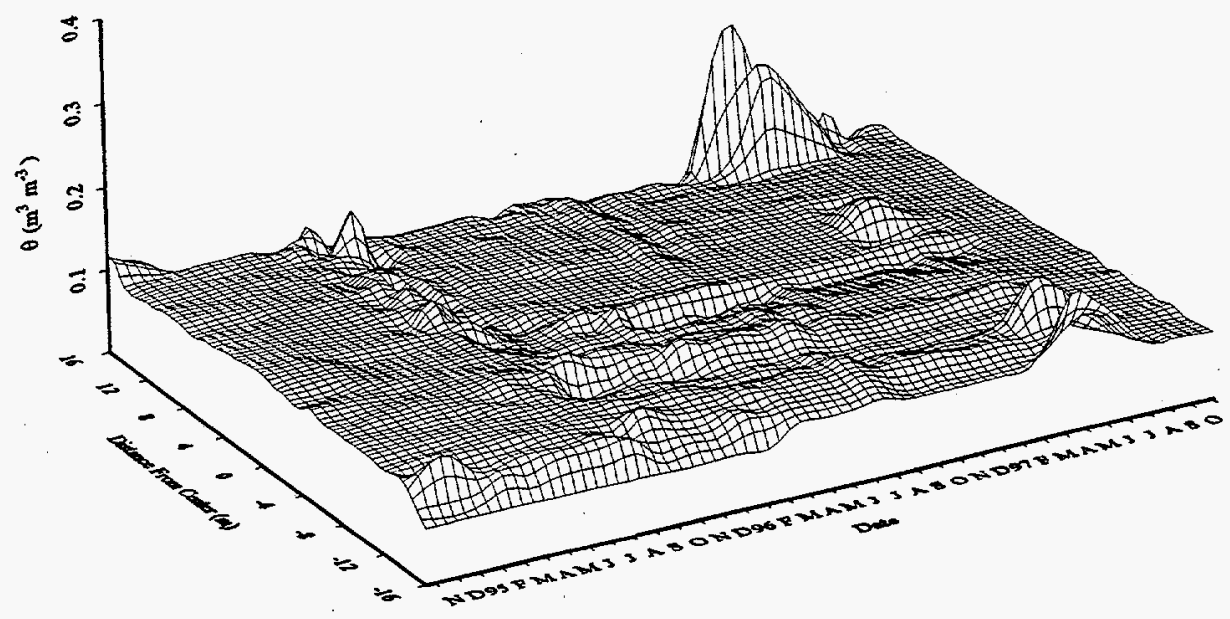

Figure 2.4. Spatial/Temporal Variations in Soil Water Content at Capillary Break - Non-irrigated Treatment. ([a] north end of treatment, tube AA3, and [b] south end of treatment, tube AA4.) 

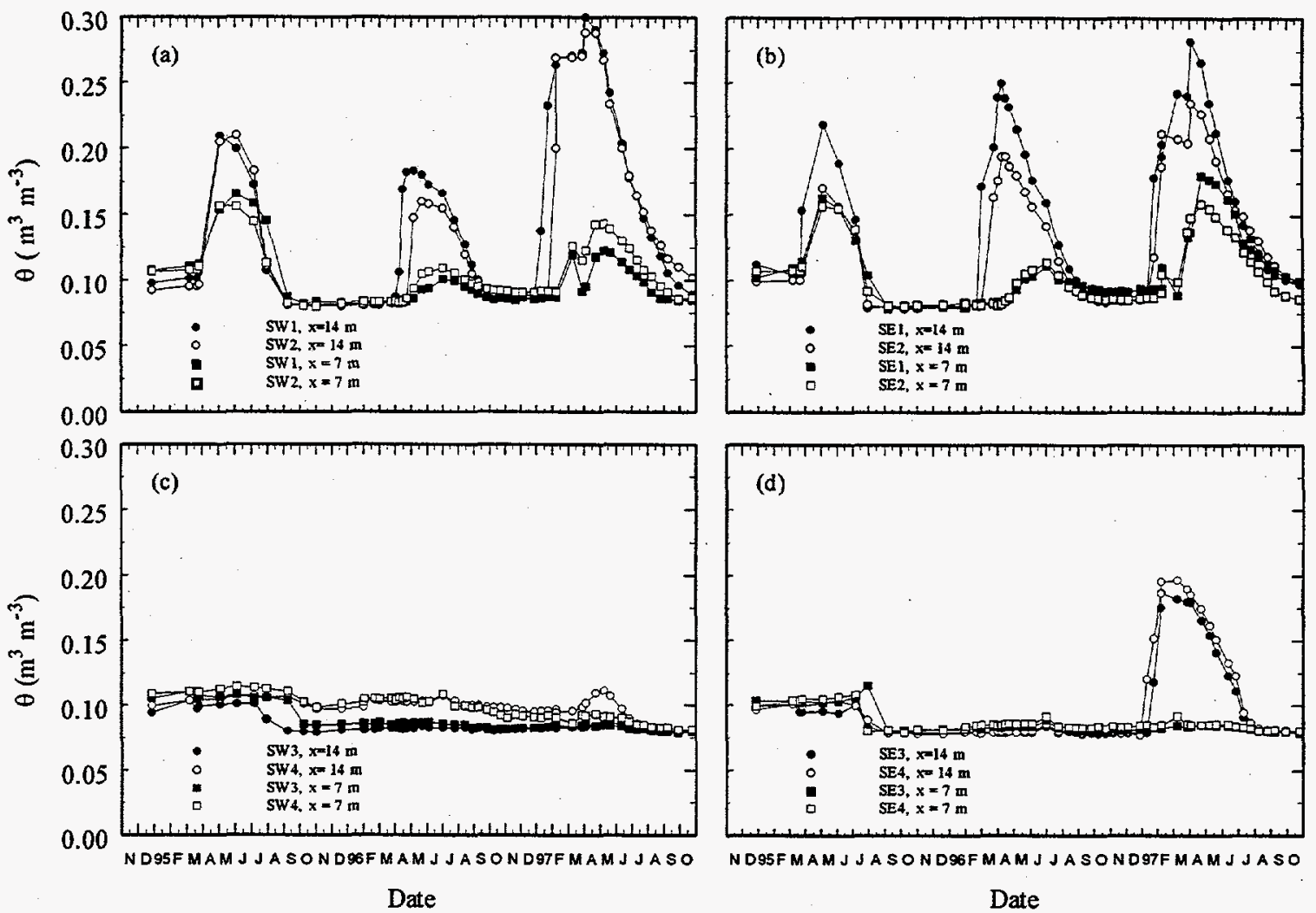

Figure 2.5. Temporal Variation in Water Content at Capillary Break of the Barrier. ([a] northwest irrigated plot, $6 \mathrm{~W},[\mathrm{~b}]$ northeast irrigated plot, $6 \mathrm{E},[\mathrm{c}]$ southwest non-irrigated plot, $3 \mathrm{~W}$, and [d] southeast non-irrigated plot. Data represent transects taken at $7 \mathrm{~m}$ and $14 \mathrm{~m}$ from center.)

\subsection{Cumulative Drainage}

Figure 2.6 presents a plot of cumulative drainage from the barrier through October 31,1997 . Table 2.1 summarizes the amount of water drained from each plot and shows the relationship with precipitation. Except for WY-1995, the irrigated gravel slope drained consistently less than the basalt slope. On average, drainage from the gravel slope between WY-1995 and WY-1996 was 18\% less than the basalt slope. This observation is not surprising, considering the difference in structure of the two slopes and the inherently higher storage capacity of the gravel fill. Over the three WY, the gravel slope drained $384.5 \mathrm{~mm}$ of water, or $29.9 \%$ of the precipitation, compared to $439.1 \mathrm{~mm}$ of water, or $34.2 \%$ of precipitation drained by the basalt slope. The non-irrigated treatment shows a completely different picture. Over the 3 years, the non-irrigated basalt drained $185.6 \mathrm{~mm}$ of water ( $22.8 \%$ of precipitation), compared to $255.2 \mathrm{~mm}$ of water ( $31.4 \%$ of precipitation) drained by the gravel. Averaged over the same period, the non-irrigated basalt slope drained only $56.7 \%$ of the water drained by the non-irrigated gravel slope, even though both were exposed to the same quantity of precipitation. 

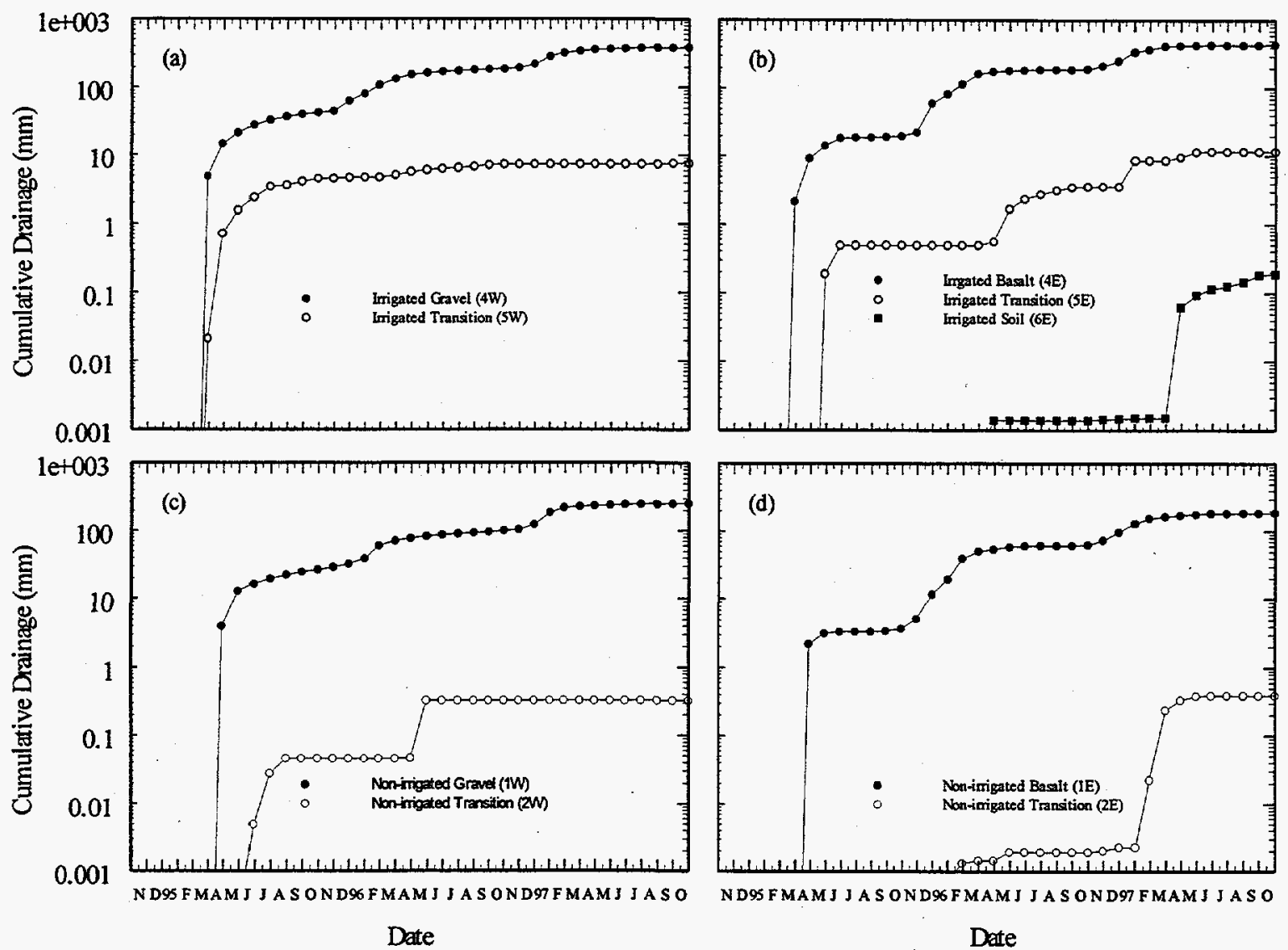

Figure 2.6. Cumulative Drainage from 12 Collection Zones on the Asphalt Pad of Barrier.

([a] northwest irrigated main plots $4 \mathrm{~W}, 6 \mathrm{~W}$ and transition zone $5 \mathrm{~W}$; [b] northeast irrigated plots main plots $4 \mathrm{E}, 6 \mathrm{E}$, and transition plot $5 \mathrm{E}$; [c] southwest non-irrigated main plots $1 \mathrm{~W}, 3 \mathrm{~W}$, and transition plot $2 \mathrm{~W}$; and [d] southeast non-irrigated main plots $1 \mathrm{E}, 3 \mathrm{E}$, and transition plot $2 \mathrm{E}$.)

\subsection{Side-slope Drainage Hypothesis}

At present, no experimentally based understanding exists of the performance of protective side slopes of capillary barriers. Thus, the reason for the difference in hydrologic performance of the two side slope configurations difference was not immediately obvious. In order to better understand the performance difference, data were analyzed on a monthly basis to identify any controlling factors. It appears that both side slope configurations show a seasonally dependent drainage with a decline in drainage in the spring and summer and an increase in the winter. These data have led to development of a hypothesis that governs the hydrologic performance of the side slopes.

The hypothesis is that advective airflow reduces drainage on the basalt side slope. Each spring (March, April, May), drainage is relatively high as cool temperatures and relatively high humidity do not 
Table 2.1. Amounts of Water Diverted by the Asphalt Pad (Drainage) at the Prototype Barrier and the Relationship to Precipitation.

\begin{tabular}{|c|c|c|c|c|c|c|c|c|c|}
\hline \multicolumn{2}{|c|}{ Treatment } & \multicolumn{2}{|c|}{ WY-1995 } & \multicolumn{2}{|c|}{ WY-1996 } & \multicolumn{2}{|c|}{ WY-1997 } & \multicolumn{2}{|c|}{ WY-1995-WY-1997 } \\
\hline Precip. (a) & Plot ${ }^{(a)}$ & $\mathrm{D}(\mathrm{mm})$ & $\% \mathrm{P}$ & $\mathrm{D}(\mathrm{mm})$ & $\% \mathrm{P}$ & $\mathrm{D}(\mathrm{mm})$ & $\% \mathrm{P}$ & $\mathrm{D}(\mathrm{mm})$ & $\% \mathrm{P}$ \\
\hline \multirow[t]{6}{*}{$3 X^{(b)}$} & gravel $(4 \mathrm{~W})^{(\mathrm{c})}$ & 42.428 & 14.74 & 142.289 & 28.85 & 191.545 & 38.00 & 384.472 & 29.92 \\
\hline & trans. $(5 W)$ & 4.535 & 0.93 & 2.727 & 0.55 & 0.297 & 0.06 & 7.562 & 0.51 \\
\hline & soil $(6 W)$ & 0.000 & 0.00 & 0.017 & 0.00 & 0.000 & 0.0001 & 0.018 & 0.00 \\
\hline & soil (6E) & 0.000 & 0.00 & 0.001 & 0.00 & 0.202 & 0.04 & 0.203 & 0.01 \\
\hline & trans. (5E) & 0.489 & 0.10 & 3.076 & 0.62 & 7.976 & 1.58 & 11.541 & 0.78 \\
\hline & basalt $(4 \mathrm{E})^{(\mathrm{c})}$ & 19.734 & 6.86 & 171.146 & 34.70 & 224.383 & 44.51 & 439.140 & 34.17 \\
\hline \multirow[t]{6}{*}{$1 \mathrm{X}^{(\mathrm{b})}$} & gravel (1W) & 26.460 & 9.20 & 71.316 & 30.55 & 152.111 & 52.17 & 255.220 & 31.40 \\
\hline & trans. $(2 W)$ & 0.045 & 0.02 & 0.277 & 0.12 & 0.000 & 0.00 & 0.323 & 0.04 \\
\hline & soil $(3 W)$ & 0.000 & 0.000 & 0.000 & 0.00 & 0.000 & 0.0 & 0.000 & 0.00 \\
\hline & soil (3E) & 0.020 & 0.01 & 0.068 & 0.03 & 0.000 & 0.00 & 0.088 & 0.01 \\
\hline & trans. (2E) & 0.000 & 0.00 & 0.002 & 0.00 & 0.385 & 0.13 & 0.388 & 0.04 \\
\hline & basalt (1E) & 3.708 & 1.29 & 58.953 & 25.26 & 111.863 & 38.36 & 185.560 & 22.83 \\
\hline
\end{tabular}

(a) Abbreviations in this column: Precip = precipitation; $3 \mathrm{X}=$ irrigated at 3 times LTA; $1 \mathrm{X}=$ non-irrigated; trans. $=$ transition zone.

(b) Drainage in $\mathrm{mm}$ of water can be converted to a volume in liters by multiplying $\mathrm{D}(\mathrm{mm})$ by 322 on the main plots and by 92 on the transition plots.

(c) The gravel and basalt slopes did not start receiving irrigation until WY-1996 although some additional water might have been added during testing of the irrigation system. For these calculations, it is assumed that precipitation is equivalent to that on the non-irrigated plots.

provide ideal conditions for evaporation from the side slopes. In the summer months (June, July, August), higher temperatures and lower humidity lead to more ideal conditions and the rate of water loss increases, causing a corresponding decrease in drainage. As the data show, drainage from the gravel is relatively consistent throughout the year; the reduction in drainage is most noticeable on the basalt side slopes. This situation is due to the open structure of the material resulting from the loose packing of 25$\mathrm{cm}$-diameter blocks, as well as to higher thermal gradients. The dark-colored basalt adsorbs more energy and, therefore, becomes hotter than the gravel. In the fall (September, October, November), lower temperatures again reduce the evaporation potential and the drainage on the basalt slope increases. This trend continues through the winter months (December, January, February) until the spring warm-up causes another reversal in drainage amounts. 


\subsection{Silt-loam Drainage Hypothesis}

Apart from small seasonal discharges from the soil covered plots that have been attributed to condensation, no drainage from the soil-covered plots has occurred. The exception is the irrigated northeast plot (6E) that has drained consistently since late April 1997. The total amount of water drained through October 31,1997 was $65.4 \mathrm{~L}$ or $0.203 \mathrm{~mm}$. The silt loam cover was designed with a storage capacity of $600 \mathrm{~mm}$ of water, more than three times the LTA annual precipitation for the Hanford Site. A precursor for drainage from the silt loam profile is a water storage, $S$, in excess of the 600 -mm storage capacity. Because $S$ never exceeded the design capacity, the drainage from $6 \mathrm{E}$ raises a question about the source of this water.

There are two hypotheses about the possible source of the water. First, it is hypothesized that the water is draining from localized regions within the plot. It is possible that moisture conditions along the surface monitoring transect are not representative of the whole plot. In this case, moisture conditions in a localized region could cause drainage without detection by routine monitoring. Such a condition would be compounded by the current use of a site-averaged calibration for the neutron probe (from which $S$ is inferred).

A second hypothesis attributes the drainage to water from the transition zones. The current design of the transition zone results in an inward sloping interface between the fine soil layer and the protective slope (see Figure 1.1). Under very wet conditions, such as occurred in the winter of WY-1997, water ponding along the outer edge of soil-covered plots tends to move downward along the interface due to the capillary break formed by the fine-over-coarse soil sequence. Water could then accumulate at the base of the transition zone and drain through the soil-covered collection zones. Such a scenario could occur without causing a detectable change in $S$. The maximum depth to which $\theta$ is measured is $1.85 \mathrm{~m}$, avoiding the possible bias caused by textural discontinuity at $2.0 \mathrm{~m}$. If the capillary break hypothesis is correct, more drainage is expected from the eastern plots because the air-entry potential of basalt riprap is considerably higher than that of gravel.

In order to determine the reason for the drainage, and to validate the utility of the current neutron probe calibration, a series of soil cores was taken in late October, while $6 \mathrm{E}$ was still draining. The cores were removed from the existing transect and from about $10 \mathrm{~m}$ north of the existing transect in $6 \mathrm{E}$. The maximum $\theta$, determined by gravimetry, was $0.15 \mathrm{~m}^{3} \mathrm{~m}^{-3}$ at the $2.0-\mathrm{m}$ depth, north of the transect, compared to $0.11 \mathrm{~m}^{3} \mathrm{~m}^{-3}$ along the existing transect. Although this measurement was wetter than the samples obtained along the transect, detectable amounts of drainage could not be sustained under these conditions. The most accurate way to determine the drainage potential is to measure the matric potential, $\psi$. Preliminary results from measurements taken at the 2-m depth in $6 \mathrm{E}$ in November show $\psi$ of $-615 \mathrm{~cm}$ of water, not sufficient to explain the continued drainage.

A series of heat dissipation units, HDU, installed at each monitoring station provide indirect estimates of $\psi$. HDU are also installed adjacent to the horizontal neutron access tubes, about $15 \mathrm{~cm}$ above the geo-textile fabric (see Figure 1.1). These sensors are most accurate at $\psi$ values of between -100 and $-15,000 \mathrm{~cm}$ water. However, with the current calibration, they can be used only in a qualitative sense to determine the point of saturation (A more thorough calibration is currently in progress.) Figure 
2.7 shows a plot of $\psi$ versus time, estimated from HDU measurements at depths of $0.23 \mathrm{~m}$ and $1.75 \mathrm{~m}$ on stations S1 and S6. A single calibration curve was used for the two depths and two locations.

The $0.23-\mathrm{m}$ measurements reflect the variability induced by irrigation and rainfall. The sharp increase in $\psi$ in early November is consistent with the onset of irrigation. The northeast plot appears to have maintained a consistently higher potential at $0.23 \mathrm{~m}$ (higher water content) throughout the year. The sharp increase in $\psi$ at the $0.2-\mathrm{m}$ depth in late March was due to the 1000 -yr storm. As expected, the increase in $\psi$ at the $1.75-\mathrm{m}$ depth lagged behind the shallower measurements. The increase at station $\mathrm{S} 6$ (plot 6E) also lagged behind that at station S1 (plot 6W). This observation is supported by vertical neutron probe measurements that showed a $\theta$ of $0.41 \mathrm{~m}^{3} \mathrm{~m}^{-3}$ at the $1.85-\mathrm{m}$ depth at station $\mathrm{S} 1$ and only $0.25 \mathrm{~m}^{3} \mathrm{~m}^{-3}$ at station $\mathrm{S} 6$. The $\psi$ at both stations approached $-100 \mathrm{~cm}$ of water in early April, about the time $6 \mathrm{E}$ started to drain.

These potentials are somewhat low for drainage to occur. The fact that $6 \mathrm{E}$ continued to drain through October 31,1997 , even though $\psi$ was less than $-600 \mathrm{~cm}$ of water, also raises doubts about vertical infiltration of water through the soil layer. This reasoning leads to the conclusion that drainage from $6 \mathrm{E}$ is most likely due to water from the roadway and transition plot, accumulating at the base of the sloped interface and draining via the $6 \mathrm{E}$ collection zone. The higher $\theta$ at the northeast edge of the barrier (Figure 2.3) supports this hypothesis. Apart from the obviously higher $\theta$ at the northeast side, drainage from $6 \mathrm{E}$ may have increased due to the predominance of shallow-rooted grasses, compared to the more deep-rooted shrubs. The grass species would be less capable of mining water from the deeper soil, which would result in a slower increase in $\psi$, as can be observed at $\$ 6$ (Figure $2.7 \mathrm{~b}$ ). Work is currently in progress to validate the neutron probe calibration and to recalibrate the HDU.

With respect to drainage, the design criterion for the barrier is to limit recharge to the waste zone to $0.5 \mathrm{~mm} \mathrm{yr}^{-1}$ or less. The low-permeability layer acts as the last line of defense to prevent water crossing the capillary break from reaching the waste zone. The results of monitoring activities to evaluate performance of the asphalt pad are summarized in the following paragraphs.

\subsubsection{Performance of the Asphalt Layer}

In WY-1997, horizontal below-asphalt measurements of $\theta(\mathrm{x})$ continued on a monthly basis. These measurements, along with others from the below-asphalt lysimeter, provide data for quantifying the functionality of the asphalt pad, as well as any underflow that might occur along the edges of the asphalt. Figure 2.8 compares the distribution of moisture at a depth of $1.0 \mathrm{~m}$ below the asphalt layer on the irrigated treatment. A negative $x$-coordinate represents locations to the south of the edge (that is, under the barrier); a positive coordinate represents locations to the east of the asphalt edge (that is, away from the barrier).

Water content to the east of the edge of the uncurbed section shows a seasonal dependence similar to that observed in water storage measured in the silt loam surface (Figure 2.8a). This dependence is expected because all water diverted by the asphalt layer is shed to the surrounding soil in the uncurbed region. The amount of diverted water is controlled by seasonal variations of natural and artificial 

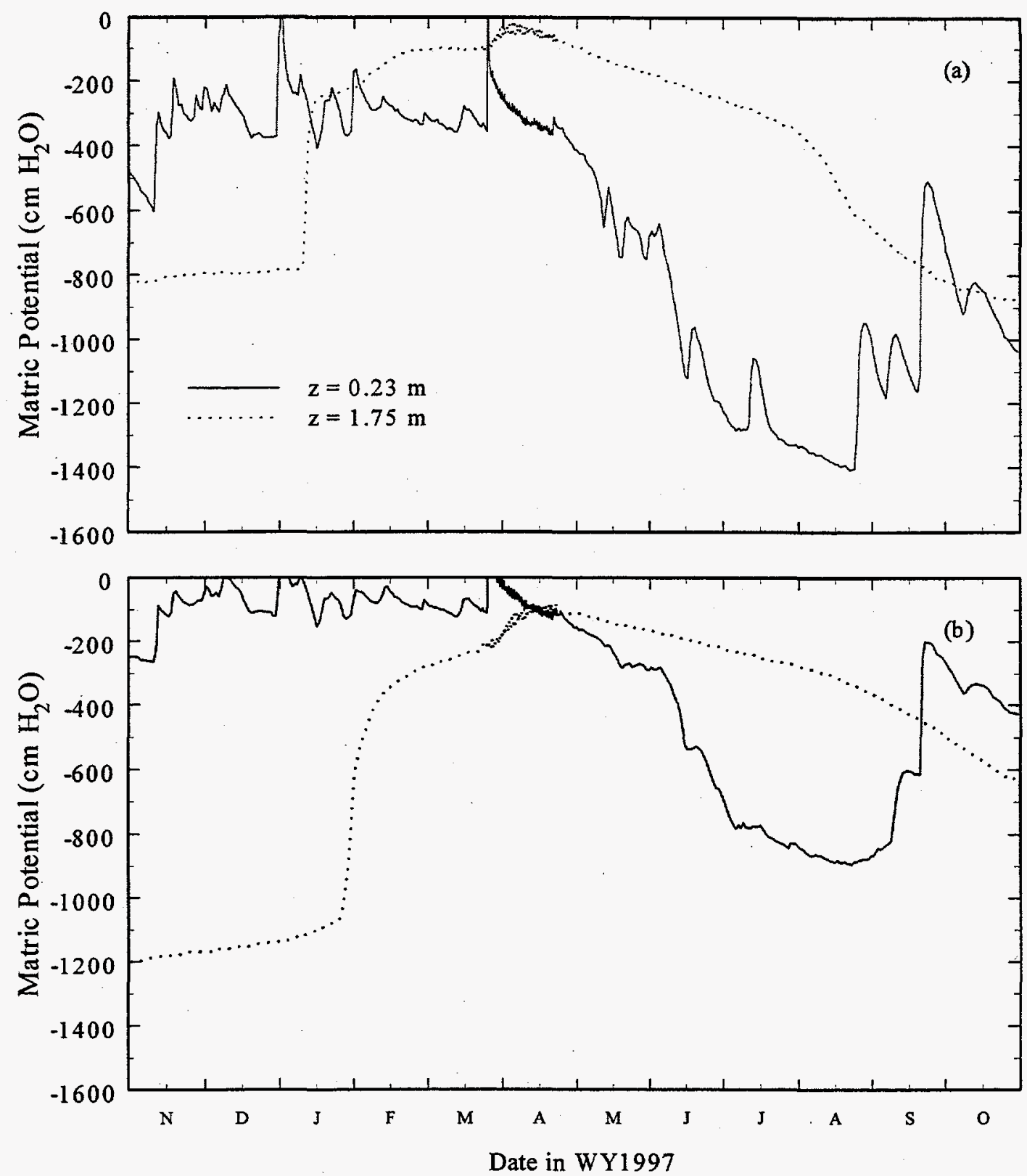

Figure 2.7. Temporal Changes in Matric Potential as Estimated with Heat Dissipation Units. ([a] S1 at northwestern irrigated plot, 6W and, [b] station S6 at northeastern irrigated plot, 6E. A single calibration curve was used at both locations.)

precipitation. The temporal variation in $\theta$ is controlled by ET, as the area to the east of the basalt slope is sparsely covered with native plant species. The most dramatic changes in $\theta$ have been limited to the edge of the asphalt pad, extending to about $1.0 \mathrm{~m}$ horizontally under the asphalt pad. These data show no 
(a)

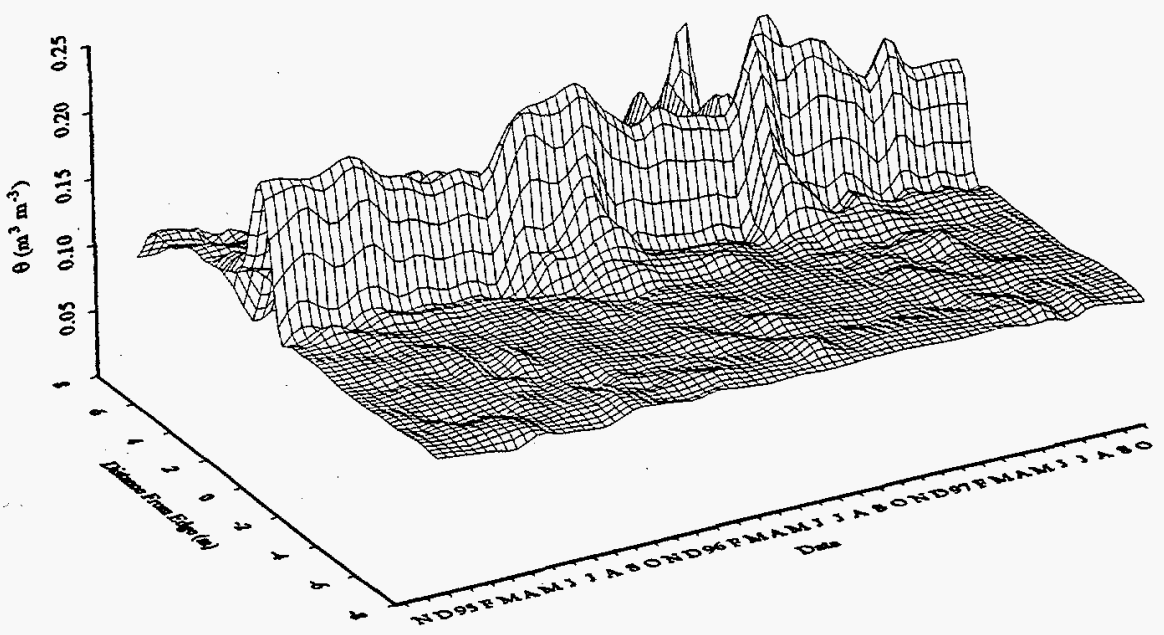

(b)

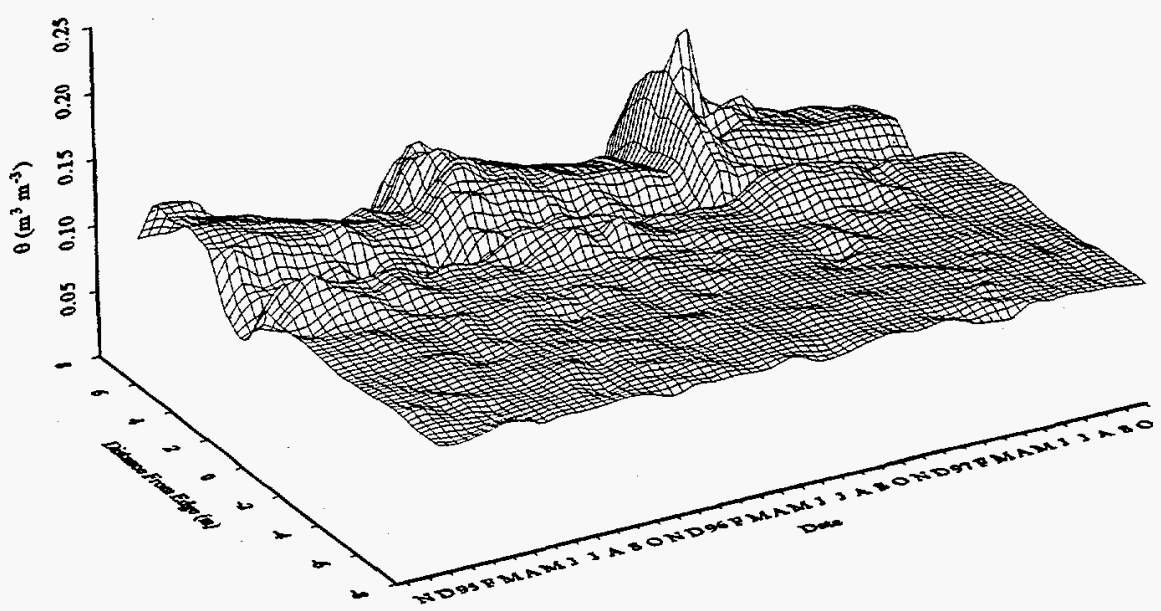

Figure 2.8. Spatial/Temporal Variations in Soil Water Content at $1 \mathrm{~m}$ Below the Asphalt Layer. (Measurements were taken in [a] tube BA1 in the northeast, uncurbed, irrigated section of the prototype, and [b] tube BA2 in the northeast, curbed, irrigated section.) 
detectable change in $\theta$ under the northeastern irrigated soil plot (6E) at the $1-\mathrm{m}$ depth. The data for the uncurbed section also shows a seasonal variation in $\theta$ along the edge of the asphalt, although $\theta$ is much lower than to the north (Figure 2.8b). To date, no change in $\theta$ is detectable under the curbed section of the asphalt pad at the 1-m depth.

Experimental work with neutron sources indicates the practical resolution varies from about a 16-cm radius at saturation to about $70 \mathrm{~cm}$ at near zero water content (Gardner 1986). Because the neutron probe measurements are made at a depth of $1 \mathrm{~m}$ below the asphalt, it is difficult, unless a major rupture occurs, to detect small changes in moisture that could result from infiltration through the asphalt layer. To complement the neutron probe measurement, a $6.5 \mathrm{~m} \times 6.5 \mathrm{~m}$ basin lysimeter was installed directly under the asphalt layer to monitor any drainage. During the first year, a series of leak tests were conducted to determine the integrity of the lysimeter. The ability to remove all of the water added was met with varying levels of success. In July 1995, the lysimeter pump was automated and connected to a tipping bucket and datalogger. On July $5,1995,0.205 \mathrm{~m}^{3}$ of water was pumped into the lysimeter and pumping started to recover this water.

Figure 2.9 shows a plot of cumulative volume recovered from the lysimeter. By the end of October $1997,0.187 \mathrm{~m}^{3}$ of water had been recovered. In WY-1997, the rate of recovery dropped significantly with only $3.66 \times 10^{-4} \mathrm{~m}^{3}(365.8 \mathrm{~mL})$ recovered through October 31,1997 . Based on horizontal belowasphalt measures of $\theta$ and the lysimeter data, no evidence indicates that water has infiltrated through the asphalt pad.

\subsubsection{Surface Runoff}

Surface RO was monitored on the barrier using a 6-m wide $x 15-\mathrm{m}$ long flume. Over the last year, information from the dataloggers and sampling equipment was collected on a monthly basis with more frequent recoveries after rain/snow storm events. During the first two years, none of the rainstorms at the barrier generated any surface RO, except the first 1000-yr storm. During the WY-1995 1000-year storm, $1.78 \mathrm{~mm}$ of RO was recorded (Gee et al. 1996). The trend of no RO was broken in FY-1997 when a combination of rain, rapid snow melt, and frozen surface soil created conditions conducive to RO. The first RO event occurred on January 18, 1997 when an irrigation was scheduled during what appeared to be ideal soil conditions. At the time, the near-surface layer of soil was frozen, resulting in a near-zero permeability. Because of an equipment malfunction, this RO event went unrecorded. The assumption is that all of the $19.6 \mathrm{~mm}$ of irrigation water ran off the surface. Three additional RO events occurred in WY-1997. The total amount of surface RO in WY-1997 is estimated at $36.3 \mathrm{~mm}$. A more detailed discussion of surface RO is presented in Section 3.2.2.

\subsubsection{Evapotranspiration}

The role of ET important in the successful performance of arid site capillary barriers. Several techniques can be used to determine ET at the field scale. The usual approach is to calculate the potential ET from climatological data and then solve the water balance equation for drainage; a rather 


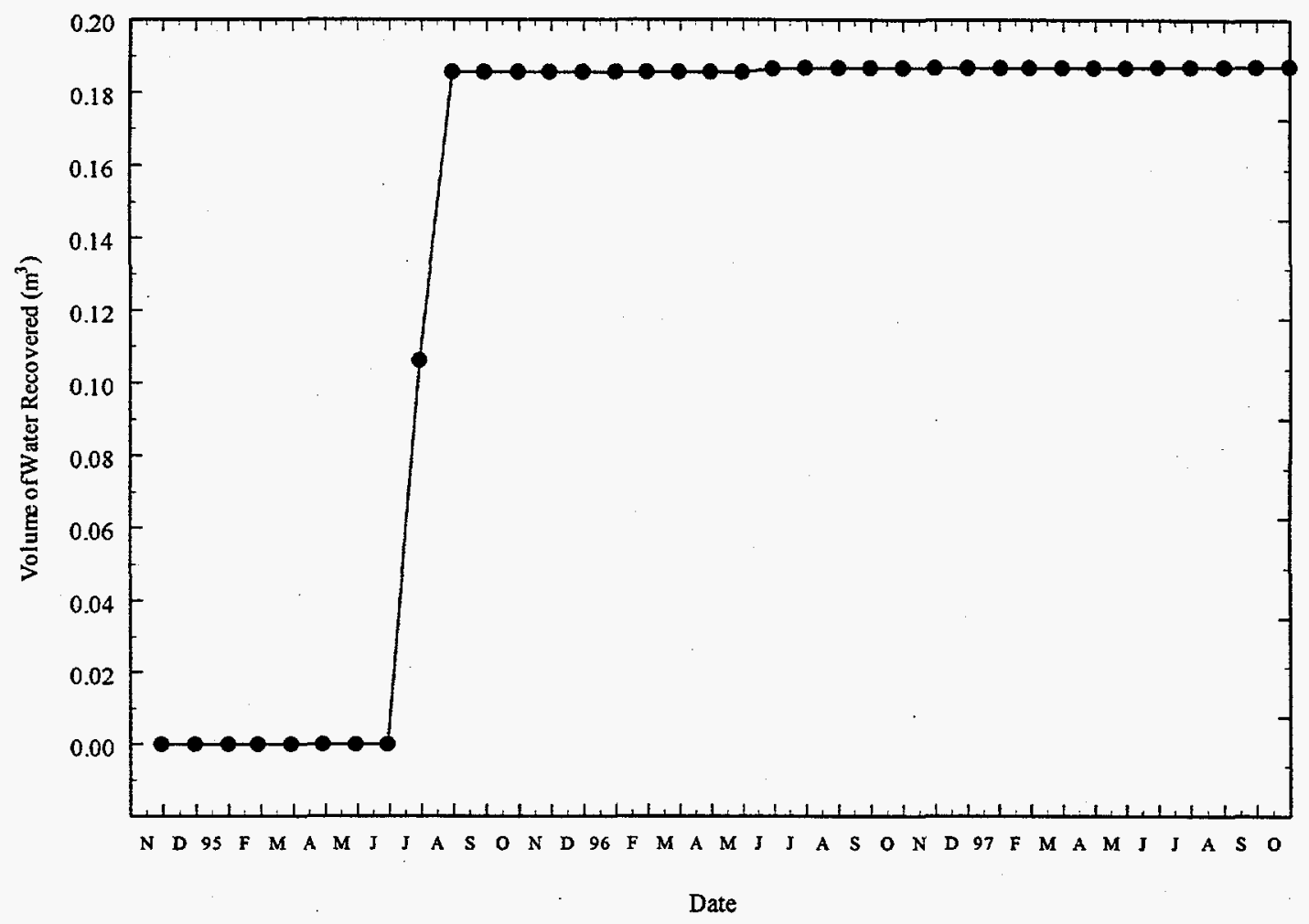

Figure 2.9. Cumulative Water Volume Recovered from the Below-Asphalt Lysimeter in FY-1997. (In a leak test initiated on July 5,1995, $0.20 \mathrm{~m}^{3}$ of water was added. By the end of October 1997 , only $0.187 \mathrm{~m}^{3}$ of this amount had been recovered, with only $365.8 \mathrm{~mL}$ recovered in WY-1997.)

inaccurate approach. Measurements at the prototype barrier are based on a water balance approach (Equation [1]), using a drainage measurement technique that allows a more accurate estimation of ET.

Data collected during the last three water years were used to calculate ET for each soil-covered plot on the two precipitation treatments at the PSB. An overall determination of ET over the three years was also made. The complete water balance for the barrier is shown in Table 2.2. ET on the irrigated plot was significantly different from that on the non-irrigated plot for the three periods compared. No significant differences between plots were found in either of the treatments. When ET is expressed as a percentage of precipitation, the irrigated treatment showed a ratio of $118 \%$ in WY-1995, but only $98 \%$ in WY-1996 and 88\% in WY-1997. On the non-irrigated treatment, ratios of ET to precipitation were $127 \%$ in WY-1995, $103 \%$ in WY-1996, and $97 \%$ in WY-1997. The ratio greater than $100 \%$ in WY-1995 could be due to an underestimation of the amount of water applied for surface stabilization; it may be due to the plants removing water that was already in the soil profile, but beyond the monitored depths. All of the calculations assumed $150 \mathrm{~mm}$ of added water, based on measurements with a flow meter. 
An obvious decline in the ratio of ET to precipitation occurred over the last three years, more so on the irrigated treatment. This decline can provide an indirect estimate of the water use efficiency of the plants. The reduction observed from WY-1995 to WY-1996 may be related partly to the change in the plant population at the PSB. In WY-1996, no Salsola kali (tumbleweed) was found at the PSB, compared to WY-1995 when a healthy stand was in place. Under wetter conditions, plants on both treatments transpired more water, although it was a smaller percentage of the total precipitation. Given the consistently higher ratios, the non-irrigated plants appear to be more efficient at recycling water to the atmosphere. Nevertheless, these data show the native plant species can easily recycle almost twice the LTA precipitation and will handle more than three times this amount, although probably over short periods only.

\subsection{Summary and Conclusions}

The third year of testing and monitoring for Water Balance Evaluation at the prototype Hanford barrier has been completed. This study demonstrates the effectiveness of the barrier in controlling infiltration to underlying wastes.

By the end of WY-1997, the irrigated treatment had received a total of $504.1 \mathrm{~mm}$ of water, $24.1 \mathrm{~mm}$ more than the targeted amount. The non-irrigated treatment had received $289.8 \mathrm{~mm}$ of water, more than 1.8 times the LTA precipitation for the Hanford Site. During WY-1997, water stored in the silt loam profile reached a high of $545 \mathrm{~mm}$ on the northwest irrigated plot $(6 \mathrm{~W})$. Water storage repeated the temporal cycle observed in the two previous years. By the end of October, storage on all of the plots had been reduced to levels similar to the two previous years. A combination of rainfall, snowmelt, and frozen, impermeable surface soils led to four RO events in WY-1997. This year was the first time RO was recorded since the 1.78-mm RO in WY-1995. A total of $36.3 \mathrm{~mm}$ of RO was recorded in WY-1997.

Horizontal measurements of water contents at the 2-m depth in the silt loam and under the asphalt pad show a seasonal cycling similar to that observed in the silt loam profile. At the 2-m depth, water content changes were greatest along the edges of the barrier, exceeding $0.30 \mathrm{~m}^{3} \mathrm{~m}^{-3}$ on the northwest (6W) irrigated plot. Lateral migration of moisture on the northeast section was particularly heavy during the last winter. The hypothesis indicates water that accumulated along the edges of the soil plots infiltrated the sloped interface of the transition zones and then migrated along the interface between the fine soil and the sand filter (that is, along the capillary break). The below-asphalt measurements showed no change in moisture content beneath any of the precipitation treatments. The below-asphalt pan lysimeter discharged $3.66 \times 10^{-4} \mathrm{~m}^{3}$ of water in WY-1997. So far, $0.187 \mathrm{~m}^{3}$ of water have been recovered from the $0.205 \mathrm{~m}^{3}$ injected for a pump test. Based on the horizontally-measured water content and lysimeter data, no evidence shows that water has infiltrated across the asphalt pad.

The two side slope configurations continue to drain, although at different rates and in different amounts. Data collected thus far suggest that under ambient conditions, the basalt side slope will produce less drainage per year than gravel surfaces because of greater advection potential. Under elevated precipitation, both configurations produced the same amount of drainage. None of the silt loam 
Table 2.2. Water Balance Summary for the Soil-covered Plots at the Prototype Barrier. ET was according to Equation (2.1).

\begin{tabular}{|c|c|c|c|c|c|c|c|c|c|c|}
\hline \multicolumn{2}{|c|}{ Treatment $^{(a)}$} & \multirow[t]{2}{*}{ Water Year ${ }^{(b)}$} & \multirow{2}{*}{$\begin{array}{c}\mathbf{S}_{1} \\
(\mathbf{m m})\end{array}$} & \multirow{2}{*}{$\begin{array}{c}S_{2} \\
(\mathbf{m m})\end{array}$} & \multirow{2}{*}{$\begin{array}{c}\Delta S \\
(\mathbf{m m})\end{array}$} & \multirow{2}{*}{$\underset{(\mathbf{m m})}{P}$} & \multirow{2}{*}{$\begin{array}{c}I \\
(\mathrm{~mm})\end{array}$} & \multirow{2}{*}{$\begin{array}{c}R \\
(\mathbf{m m})\end{array}$} & \multirow{2}{*}{$\begin{array}{c}D \\
(\mathbf{m m})\end{array}$} & \multirow{2}{*}{$\begin{array}{c}\mathbf{E T} \\
(\mathbf{m m})\end{array}$} \\
\hline Precip. & Plot & & & & & & & & & \\
\hline \multirow{9}{*}{$3 \mathrm{X}$} & \multirow{4}{*}{$6 \mathrm{~W}$} & WY-1995 & 243.53 & 124.10 & -119.43 & 287.27 & 350.60 & 1.78 & 0.00 & 755.52 \\
\hline & & WY-1996 & 124.10 & 132.10 & 8.00 & 224.28 & 247.35 & 0.00 & 0.02 & 463.61 \\
\hline & & WY-1997 & 132.10 & 144.27 & 12.17 & 289.81 & 224.92 & 36.30 & 0.00 & 466.26 \\
\hline & & WY-1995- 1997 & 243.53 & 144.27 & -99.27 & 801.62 & 822.87 & 38.08 & 0.02 & 1685.66 \\
\hline & & & & & & & & & & \\
\hline & \multirow{4}{*}{$6 \mathrm{E}$} & WY-1995 & 233.43 & 114.47 & -118.97 & 287.27 & 350.60 & 1.78 & 0.00 & 755.06 \\
\hline & & WY-1996 & 114.47 & 123.50 & 9.03 & 224.28 & 247.35 & 0.00 & 0.00 & 462.60 \\
\hline & & WY-1997 & 123.50 & 160.87 & 37.37 & 289.81 & 224.92 & 36.30 & 0.20 & 440.86 \\
\hline & & WY-1995- 1997 & 233.43 & 160.87 & -72.57 & 801.62 & 822.87 & 38.08 & 0.20 & 1658.77 \\
\hline & & & & & & & & & & \\
\hline \multirow{9}{*}{$1 \mathrm{X}$} & \multirow{4}{*}{$3 W$} & WY-1995 & 225.67 & 112.33 & -113.33 & 287.27 & 150.00 & 0.00 & 0.00 & 550.60 \\
\hline & & WY-1996 & 112.33 & 104.34 & -8.00 & 224.28 & 0.00 & 0.00 & 0.00 & 232.28 \\
\hline & & WY-1997 & 104.34 & 112.47 & 8.13 & 289.81 & 0.00 & 0.00 & 0.00 & 281.68 \\
\hline & & WY-1995- 1997 & 225.67 & 114.47 & -113.20 & 801.62 & 150.00 & 0.00 & 0.00 & 1064.82 \\
\hline & & & & & & & & & & \\
\hline & \multirow{4}{*}{$3 \mathrm{E}$} & WY-1995 & 229.60 & 106.15 & -123.45 & 287.27 & 150.00 & 0.00 & 0.02 & 560.70 \\
\hline & & WY-1996 & 106.15 & 100.40 & -5.75 & 224.28 & 0.00 & 0.00 & 0.07 & 229.97 \\
\hline & & WY -1997 & 100.40 & 109.37 & 8.97 & 289.81 & 0.00 & 0.00 & 0.09 & 280.75 \\
\hline & & WY-1995- 1997 & 229.60 & 109.37 & -120.23 & 801.62 & 150.00 & 0.00 & 0.18 & 1071.68 \\
\hline
\end{tabular}

(a) Abbreviations in this column: Precip = precipitation; $3 \mathrm{X}=$ irrigated at 3 times LTA; $1 \mathrm{X}=$ non-irrigated.

(b) Start and end dates for the WY used in these calculations were determined by the start and end dates for water storage measurements, $S_{1}$ and $S_{2}$, respectively. In WY-1995, $S_{1}$ and $S_{2}$ were September 30, 1994 through October 24, 1995; in WY-1996, $S_{1}$ and $S_{2}$ were October 24, 1997 through October 23, 1996; in WY-1997, $S_{1}$ and $S_{2}$ were October 23, 1996 through October 25, 1997. 
plots, except for the irrigated northeast plot $(6 \mathrm{E})$, produced any drainage during the last year. The northeast plot started to drain in April 1997, generating $0.204 \mathrm{~mm}$ of water by the end of October 1997. No evidence from water storage measurements supports this observation. The water draining from $6 \mathrm{E}$ is water that infiltrated along the sloped interface of the adjacent transition zone.

Water balance evaluation shows that irrigated treatment is less efficient at recycling water by ET, suggesting the native shrubs are susceptible to high levels of precipitation. Expressed as a percentage of precipitation, ET declined over the last three years, with the greater decline occurring on the irrigated treatment. The non-irrigated plants appear to be more efficient at recycling water to the atmosphere. Nevertheless, evaluation of the water balance shows that native plant species can easily recycle almost twice the LTA precipitation and will handle more than three times this amount, although probably over short periods only. 


\subsection{Water Erosion}

The loss of soil by erosion from the surface of protective barriers can reduce the thickness of the soil cover and compromise its ability to control infiltration through reduced storage capacity. One of the main agents of soil erosion is water. To understand the effect of water erosion on barriers requires knowledge of how erosion is affected by different kinds of rain and how it will vary for different soil conditions. The amount of water erosion that occurs in any given soil condition is a function of the ability of the rain to cause erosion (erosivity) and the ability of the soil to resist the erosive forces of the rain (erodibility). The Water Erosion task has focused on collecting data to characterize rain storms at the barrier, to identify soil conditions that influence erodibility and, to quantify the amount of soil loss. The goal was to develop design criteria to reduce long-term erosion potential and side slope failure.

\subsection{Scope and Objectives}

Early in the Barrier Development Program, a series of tests conducted on small field plots under simulated precipitation events was used to establish relationships between storm characteristics, sediment properties, and the run off of water and sediment on the Warden silt loam. These tests showed that rain splash, a dominant erosional process on bare plots, was relatively insignificant on vegetated surfaces. Surface runoff $(\mathrm{RO})$ and sediment yield was also reduced on vegetated surfaces. With the construction of the barrier, these tests were continued at the field-scale to validate the assumptions made during small plot tests and to provide data on their erosivity and erodibility under natural rainfall and snowmelt conditions. The scope of this task was to investigate the ability of the soil cover and side slopes to resist the destabilizing processes contributing to erosion and barrier failure and to estimate the potential amount of erosion in the long term. The objective was to develop a baseline database for the soil surface with respect to erosion and soil surface aging under natural conditions (DOE 1993). The resulting information will be combined with the results from the wind tunnel and offsite test plots to identify design problems that may develop over the life of the PSB; to finalize surface design criteria; and to provide supporting data and information to the other tasks (DOE 1993).

\subsection{Water Erosion Testing and Monitoring Activities}

Water erosion is function of the erosivity and erodibility of the soil, or

$$
\text { Erosion }=f(\text { erosivity })(\text { erodibility })
$$

Erosivity is the potential of the rain to cause erosion and is a function of the physical characteristics of rainfall. Erodibility is a measure of the soil's ability to resist erosion and is a function of the physical characteristics of soil; topographic features, especially the slope, and how the soil is managed, whether it is covered or not. Thus, activities of the Water Erosion task were aimed at quantifying the components of Eq. (3.1). Activities performed to quantify these components are based on the treatability test plan (Gee et al. 1993; DOE 1993) and are grouped in the following four categories: 1) rainfall characteristics, 2) surface and sediment yield, 3) soil physical properties, and 4) topographic changes and stability. The following sections summarize the results obtained over the last year. 


\subsubsection{Rainfall Characteristics}

The important influences on erosivity are the amount and intensity of rainfall. The PSB is fitted with an automated tipping bucket system for monitoring rainfall amounts from which intensities can be inferred. Monitoring frequency is event driven, increasing from the regular 1-hr intervals to $1-\mathrm{min}$. intervals during precipitation events.

The best estimator of soil loss is the product of kinetic energy and the 30-minute rainfall intensity, $\mathrm{I}_{30}$ (Wischmeier et al. 1958). The $I_{30}$ is the greatest average intensity observed in any 30 -minute period

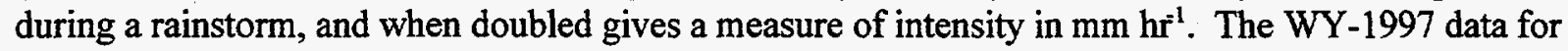
the last year were analyzed to identify the highest $I_{30}$ and the maximum erosion potential (erosivity index, EI). Figure 3.1 shows a cumulative plot of precipitation versus time on January 18, 1997. This event was an irrigation activity that lasted for 284 minutes, during which time a total of $22.86 \mathrm{~mm}$ of water was applied. The maximum $\mathrm{I}_{30}$ occurred between 90 and 150 minutes, resulting in an intensity of $9.65 \mathrm{~mm}$ $\mathrm{hr}^{-1}$. The EI of this event was calculated according to the method of Wischmeier et al. (1958). First, the kinetic energy was calculated according to

$$
E=11.9+8.7 \log I
$$

where

$E=$ kinetic energy $\left(\mathrm{J} \mathrm{m}^{-2} \mathrm{~mm}^{-1}\right)$

$\mathrm{I}=$ rainfall intensity $\left(\mathrm{mm} \mathrm{hr}^{-1}\right)$

The erosivity index, EI, was then calculated according to,

$$
E I=\frac{E \cdot I_{30}}{1000}
$$

Calculated kinetic energy was $22.0 \mathrm{~J} \mathrm{~m}^{-2} \mathrm{~mm}^{-1}$ resulting in an EI of 4.85 units. This figure is much lower than the average annual EI of 20 for this area (Wischmeier and Smith 1978). It is also considerably smaller than the 15.07 calculated for the first 1000-year storm in WY-1995 which generated less than 2 $\mathrm{mm}$ of surface RO. Because the most erosive precipitation event was characterized by an EI less than the annual average, any RO or soil erosion is due entirely to soil conditions. As is noted in the next section, four RO events were observed in WY-1997.

\subsubsection{Surface RO and Sediment Yield}

The northwestern corner of the prototype barrier was fitted with a 6.1 -m wide $\mathrm{x}$ 15.24-m long flume (see Figure 1.3) to permit the monitoring of RO and sediment yield from a representative length of the 


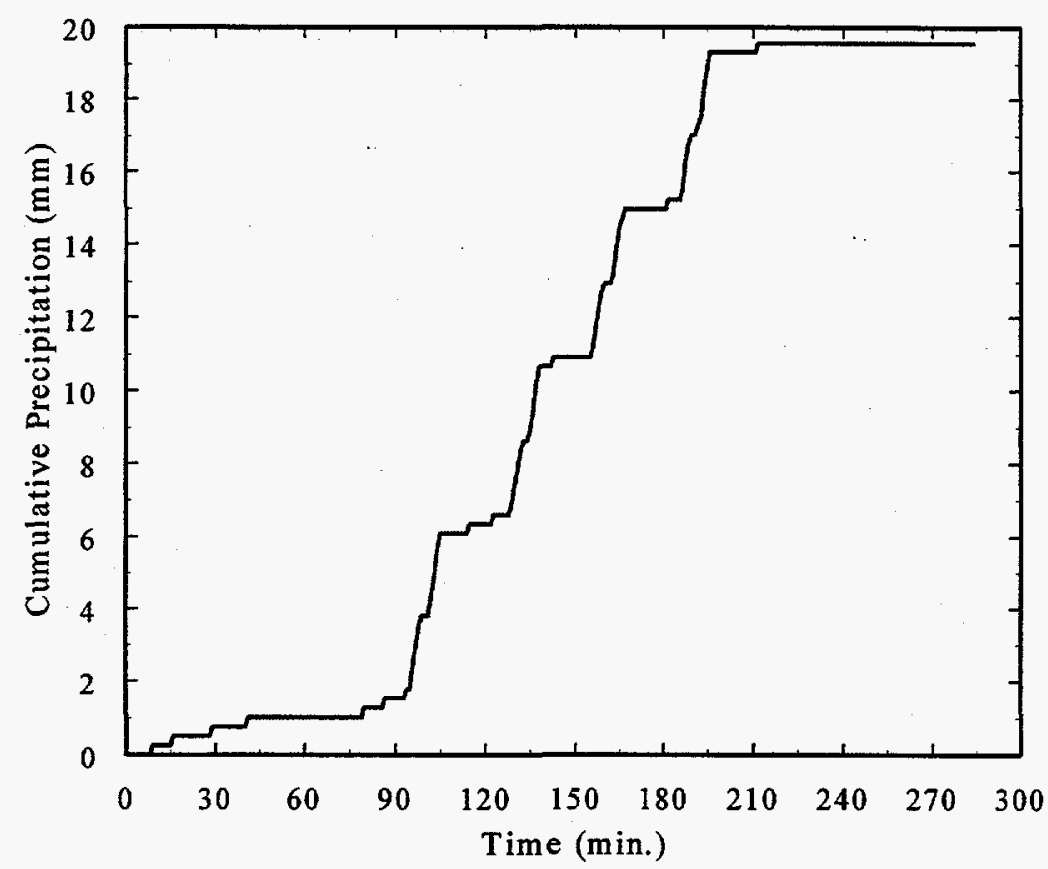

Figure 3.1. Cumulative Precipitation Versus Time on January 18, 1997. (A total of $22.86 \mathrm{~mm}$ of water was received over $284 \mathrm{~min}$. The 30-min. period with the greatest of precipitation $[60$ to 90 minutes into the event] was used to estimate the intensity, the kinetic energy, and the EI.)

barrier. The flume is monitored by an automated water and sediment sampler with a monitoring frequency that also changes with the intensity of the RO event. Over the last year, information from the data loggers and sampling equipment was collected on a monthly basis with more frequent recoveries during and immediately after precipitation events. This year, for the first time since first the simulated 1000-year activity on March 26, 1995, surface RO was recorded at the PSB. During the winter months, four major RO events were observed.

Figure 3.2 shows a plot of the RO data collected during the active period. The first RO event occurred on January 18, 1997 when an irrigation event was scheduled under what appeared to be ideal soil conditions. At the time, however, the near-surface soil was partially frozen, resulting in a nearly impermeable surface layer. When RO was first observed, water application was ceased immediately. Presumably, all of the $19.56 \mathrm{~mm}$ of the water applied ended up as surface RO. Most of the water accumulated at the northwestern and northeastern corners of the barrier. During this RO, the eventdriven flow monitoring system failed to activate and part of the event went unrecorded. A combination of rain and snowmelt following the January 18, 1997 event led to localized ponding on the surface and sporadic RO events.

The second RO event started around 1:15 p.m. on January 30, 1997 after an ambient temperature of $16.2{ }^{\circ} \mathrm{C}$ initiated a rapid snowmelt. The flow rate reached a maximum of $5.4 \times 10^{-5} \mathrm{~m}^{3} \mathrm{~s}^{-1}$ at the end of 

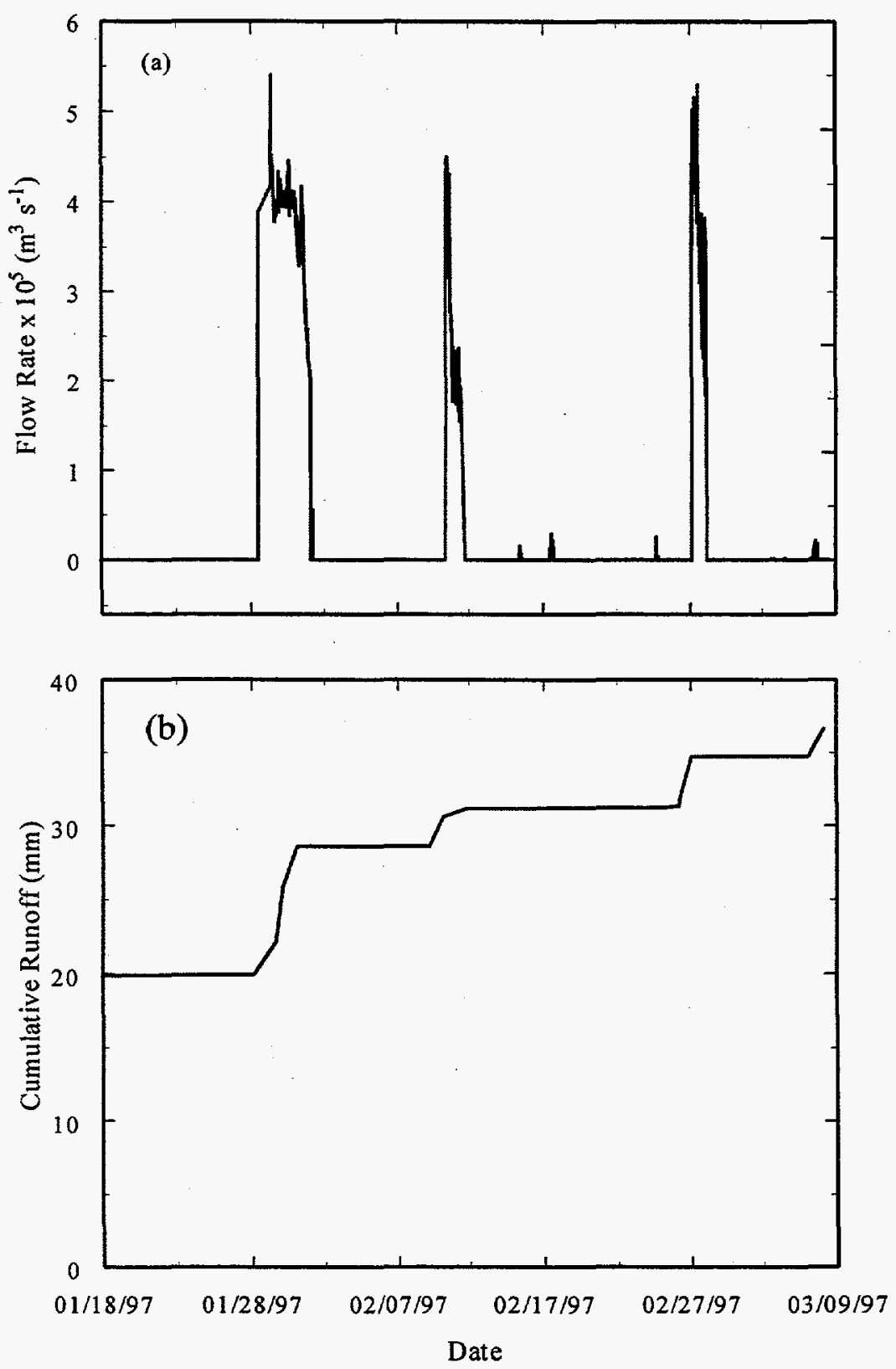

Figure 3.2. History of Surface RO Events in WY-1997 (a) Flow Rates, (b) Cumulative RO. (Due to an equipment malfunction on January 18, 1997, the first of four major events in WY-1997 went unrecorded. Total RO in WY-1997 was $36.3 \mathrm{~mm}$, including $19.6 \mathrm{~mm}$ of irrigation water assumed RO on January 18, 1997.) 
January.. A total of $8.7 \mathrm{~mm}$ of RO was recorded and the event continued into early February as the permeability of the soil remained quite low. The third event started at 10:45 a.m. on February 12, 1997 when the temperature increased from $0^{\circ} \mathrm{C}$ to $14^{\circ} \mathrm{C}$, one day after a $68-\mathrm{mm}$ snowfall. The fourth major event for the year started at 4:00 p.m. on March 1, 1997 and generated $3.5 \mathrm{~mm}$ of RO. No RO was recorded in response to the 1000-year storm event in late March and no sediment was generated during any of the events. Assuming that all of the irrigation water applied on January 18, 1997 ran off the surface, a total of $36.3 \mathrm{~mm}$ of RO occurred in WY-1997. RO occurred from both the irrigated and nonirrigated plots. Most of this water accumulated along the eastern and western edges of the barrier with the greatest accumulation at the northeast and southeast corners. This accumulation led to significant increases in water stored in the profile and an increase in water content at the capillary break, as shown in subsection 2.2.3.

When compared to previous water erosion tests, that RO occurs only in the winter months is not surprising. Previous tests on large-scale vegetated plots with gravel admix and an antecedent gravimetric moisture content of $0.016 \mathrm{~g} \mathrm{~g}^{-1}$, and on plots at an antecedent moisture content of $0.056 \mathrm{~g} \mathrm{~g}^{-1}$ and containing no gravel, generated $\mathrm{RO}$ of $1 \%$ of precipitation in response to a 1 -hr rainstorm with an intensity of $1536 \mathrm{~mm} \mathrm{~d}^{-1}$. During the last three years, the intensity of rainstorms occurring at the PSB was generally less than $15 \mathrm{~mm} \mathrm{~d}^{-1}$ and, as such, did not generate any RO or sediment yield. December 1996 was, by far, the wettest month ever recorded at the HMS, a total of $93.7 \mathrm{~mm}$ of precipitation (358\% of normal). During the period December 1996 through February 1997, the Hanford Site received $138.4 \mathrm{~mm}$ of precipitation, making it the wettest winter on record there. It was the combination of high precipitation, rapid snowmelt, and frozen surface soils that created conditions conducive to RO on the four occasions. Overall, the PSB performed according to design specifications, shedding water toward the edges to be diverted via the transition zones and side slopes, rather than allowing accumulation on the surface.

\subsubsection{Soil Physical Properties}

Erodibility of the barrier surface is dependent on soil physical properties and vegetative cover, and can, therefore, change over time in response to natural and artificial processes. Processes, such as animal burrowing, may enhance infiltration. Settlement and consolidation may lead to increases in bulk density and an increase in surface RO due to a decrease in hydraulic conductivity. Over the last year, the soil surface was monitored to quantify seasonal or annual changes in soil physical properties. Soil property data were collected at the approximate center of each grid cell (Figure 1.3) using a Troxler nuclear density gauge. This gauge provides measures of soil water content, as well as the wet and dry bulk densities, $p_{b}$, of the soil. Measurements were taken at the end of August 1997 when the potential for surface water RO was quite low. The interest in surface soil water content was initially due to its effect on seasonal changes in erosivity. However, because only one measurement was taken, the data are quite limited and not presented here. Dry density data are of greater utility and are summarized in following paragraphs.

\subsubsection{Near-Surface Soil Bulk Density}

Figure 3.3 shows a plot of near-surface dry $\rho_{b}$ at the PSB in August of 1996 and 1997. The mean surface dry density, $\bar{\rho}_{b}$, excluding buffer zones, was $1695 \pm 47 \mathrm{~kg} \mathrm{~m}^{-3}$ compared to $1881 \pm 66 \mathrm{~kg} \mathrm{~m}^{-3}$ in August 1996. The Student's $t$-test was used to test the hypothesis stating no difference in $\bar{\rho}_{\mathrm{b}}$ between the 

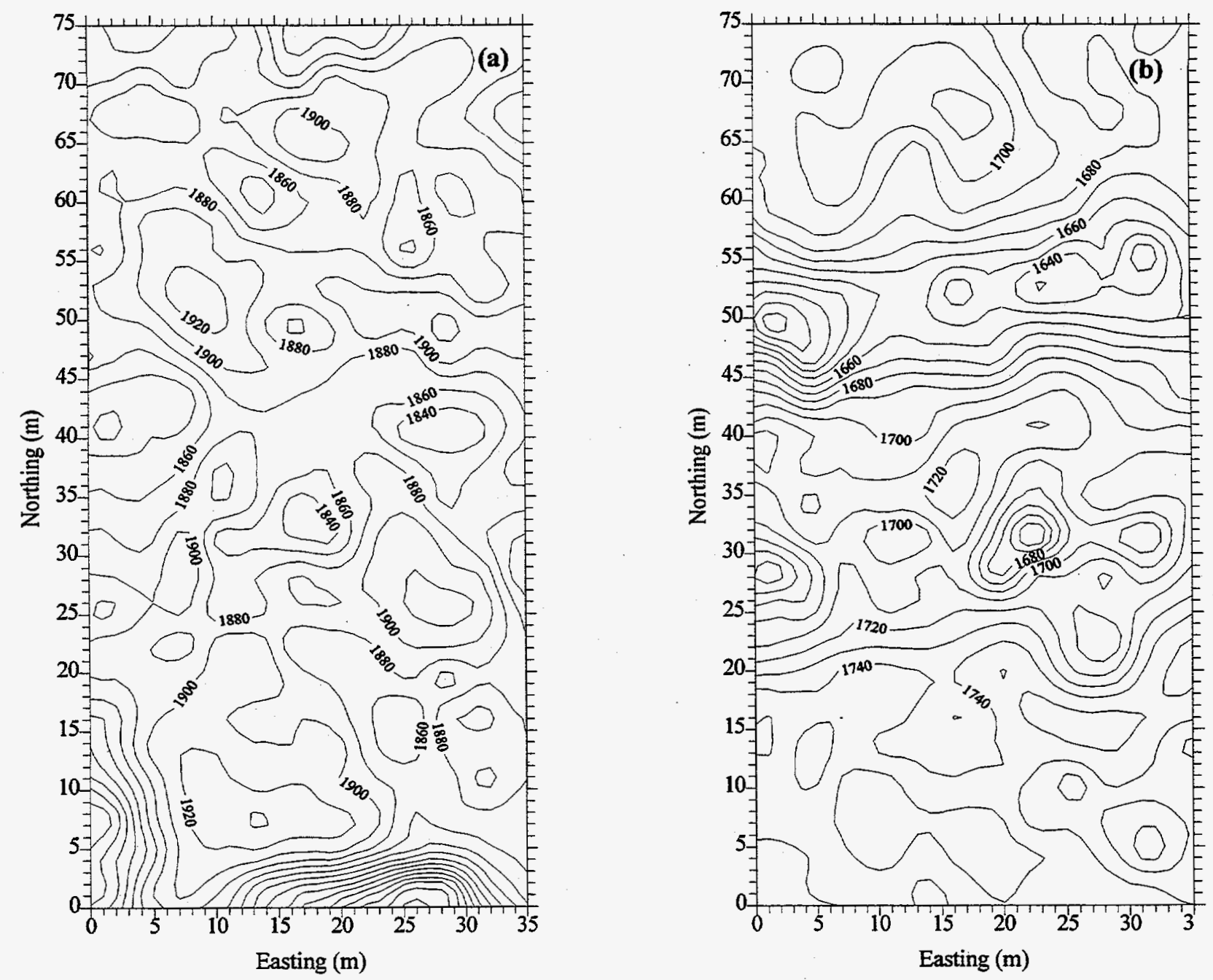

Figure 3.3. Near-Surface $(\leq 20 \mathrm{~cm})$ Dry Bulk Densities $\left(\mathrm{kg} \mathrm{m}^{-3}\right)$ at the Prototype Surface Barrier. (Densities were measured by the Troxler Neutron Density Gauge on [a] August 26, 1996 and, [b] September 2, 1997; Contour interval is $20 \mathrm{~kg} \mathrm{~m}^{-3}$.)

two years. The test confirms that $\bar{\rho}_{\mathrm{b}}$ in WY-1997 was significantly smaller $(\alpha=0.05)$ than in WY-1996. When compared to data from WY-1995, it is clear that $\bar{\rho}_{\mathrm{b}}$ has shown a steady decrease since construction of the prototype was completed. The $\bar{\rho}_{b}$ in December 1994 was 1879 a $67 \mathrm{Mg} \mathrm{m}^{-3}$. It is hypothesized that decline in $\rho_{b}$ is due to the effect of plant rooting activity and the deposition of organic matter near the surface.

To test the previous hypothesis, the WY-1997 data were further analyzed to detect differences in $\bar{\rho}_{b}$ between the two treatments and between plots within a treatment. Results of these tests show a significantly higher $\bar{\rho}_{\mathrm{b}}\left(1718 \pm 45 \mathrm{~kg} \mathrm{~m}^{-3}\right)$ on the non-irrigated treatment, compared to the irrigated treatment where $\bar{\rho}_{\mathrm{b}}$ was only $1673 \pm 39 \mathrm{~kg} \mathrm{~m}^{-3}$. Differences between plots within the treatments were not significant at $\alpha=0.05$. These results suggest a negative correlation between dry density and precipitation regime. Such a relationship could result from an increase in rooting activity and soil organic matter 
content under elevated precipitation. In September 1997, a total of 14 soil samples were collected from the two treatments at various locations on the PSB, and from the Warden Silt loam pile (control treatment) northwest of the barrier and analyzed for the percent organic carbon $(\% \mathrm{C})$ content. The mean $\% \mathrm{C}$ on the irrigated treatment was $2.6 \pm 0.11 \%$, compared to $2.03 \pm 0.40 \%$ in the control sample and $2.03 \pm 0.10 \%$ on the non-irrigated treatment. The $\% \mathrm{C}$ on the irrigated treatment was significantly larger than that on the control and non-irrigated treatments, but no difference was found between the nonirrigated and control treatments.

The change in $\rho_{b}$ between August 1996 and September 1997 is shown in Figure 3.4. Except at the southeastern corner (easting $30-35 \mathrm{~m}$ ) of the PSB, density generally decreased. In the past, this area also showed decreases in density (Gee et al. 1996). The increase in density observed this year may be due to the ponding that occurred in this area last winter.

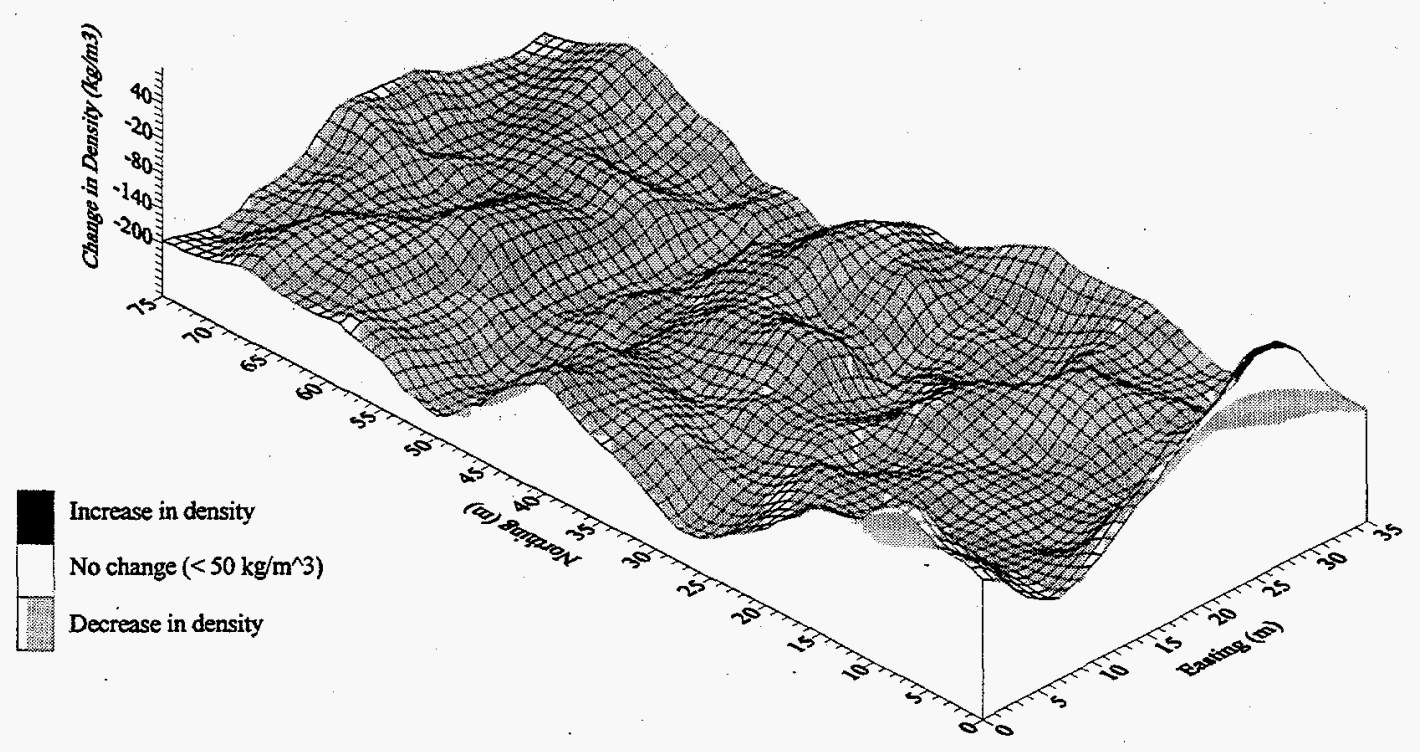

Figure 3.4. Change in Near-Surface $(\leq 20 \mathrm{~cm})$ Dry Bulk Densities $\left(\mathrm{kg} \mathrm{m}^{-3}\right)$ at the Prototype Surface Barrier Between August 26, 1996 and September 2, 1997. (Densities were measured by the Troxler neutron density gauge.)

The conclusion is that establishment of vegetation on the PSB led to a significant reduction in nearsurface $(\leq 0.20 \mathrm{~m})$ bulk density. Bulk density also shows a negative correlation with water application that can be attributed to the increase in soil $\% \mathrm{C}$ that occurred under elevated precipitation. Because a decrease in near-surface density would be accompanied by an increase in saturated hydraulic conductivity, a further decline in density could lead to a more permeable surface zone and reduced potential for surface RO. These factors contribute to creating a soil surface that is less vulnerable to erosion. 


\subsubsection{Topographic Changes}

Vertical deformation of the soil surface can be caused by consolidation or expansion of the barrier materials and by differential settlement of the barrier foundation. These processes can influence barrier stability and are best quantified by monitoring changes in surface elevation. During the last year, two civil surveys were conducted to quantify topographic changes, once on January 8, 1997 and once on September 2, 1997. The civil surveys included measurement of surface elevation of the two settlement gauges, and spatial location of the 12 gauges on the rock slope (see Figure 1.3).

\subsubsection{Surface Elevation}

Elevation measurements were taken at the location of each stake on the 3-m $\times 3-\mathrm{m}$ grid using an EDM system. The results of the two surveys are presented as contour plots in Figure 3.5.
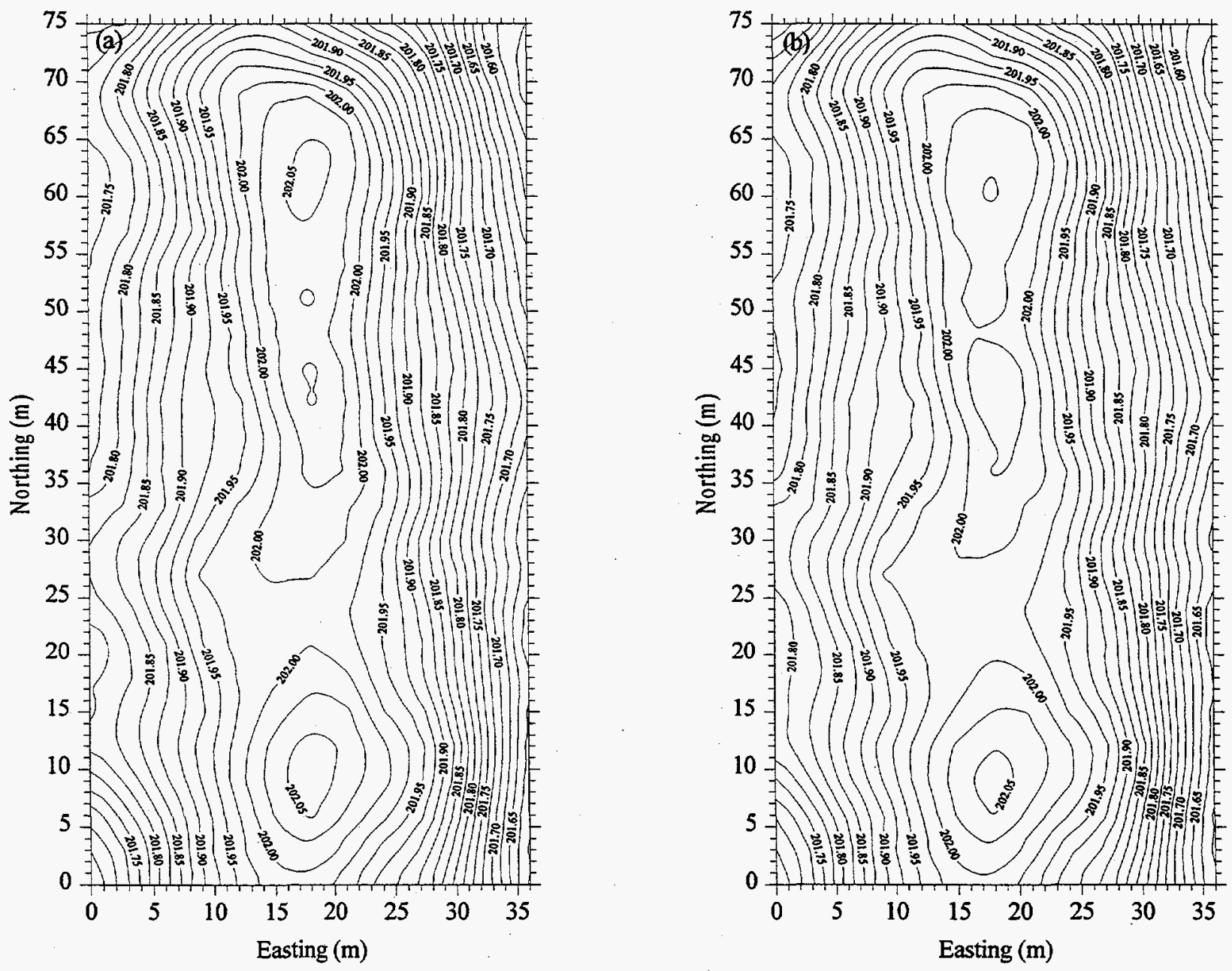

Figure 3.5. Surface Elevations at the Prototype Surface Barrier During WY-1997. ([a] surface elevation, in meters, on January 8, 1997; and [b] surface elevation (m) on September 4, 1997. Mean EDM closure error in January was $0.00275 \mathrm{~m}$ and $0.004 \mathrm{~m}$ in September.) 
The first survey on January 8, 1997 was conducted shortly after the heavy snow cover (approximately $304 \mathrm{~mm}$ ) had melted. The surface, though not muddy, was still rather wet. The main features of the barrier, for instance the $2 \%$ slope from the center toward the edges, remained unchanged between the two surveys. Figure 3.6 shows the difference in elevation between January and September. This plot shows a small decrease in elevation in that period.

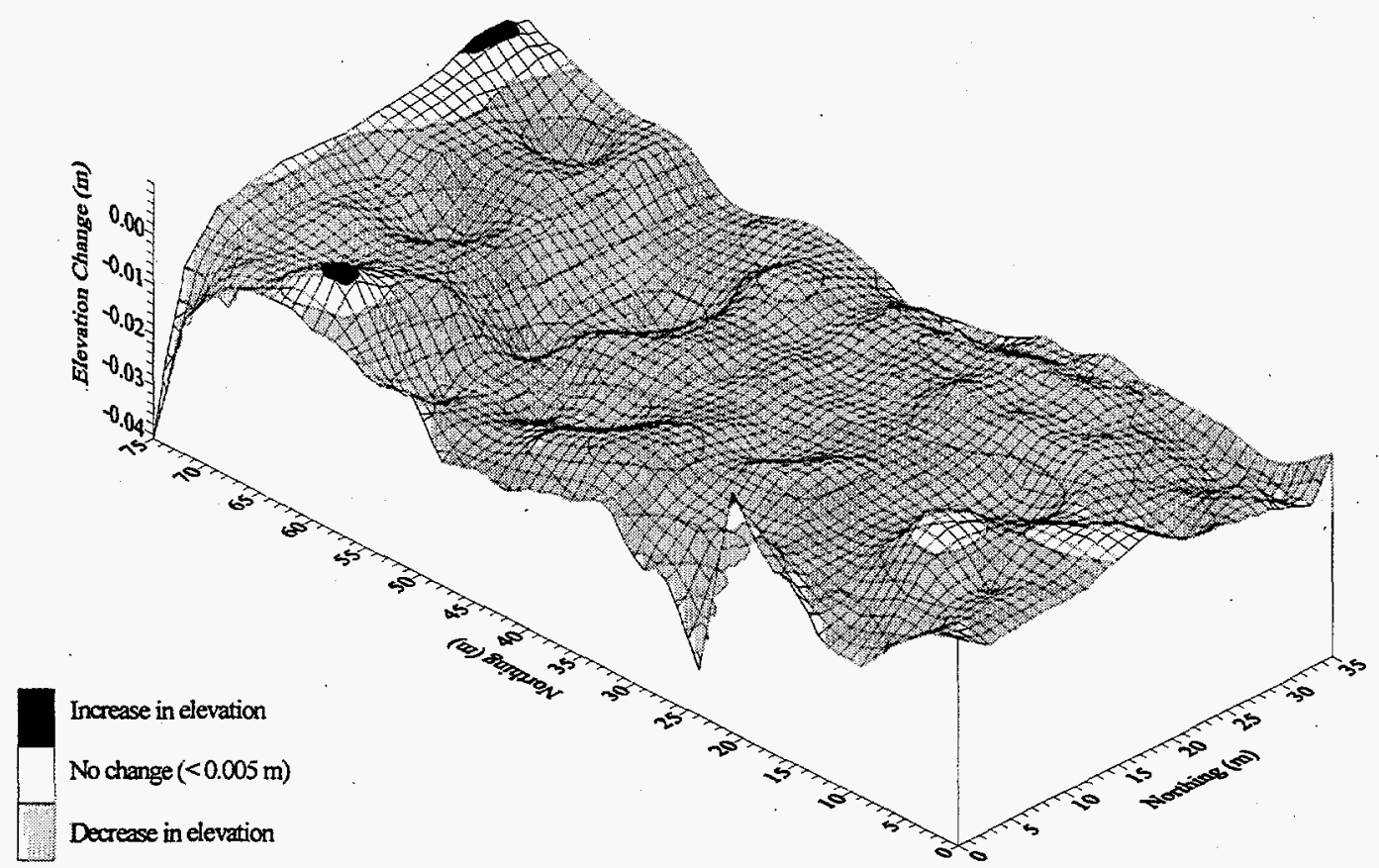

Figure 3.6. Change in Surface Elevation at the Prototype Surface Barrier Between January 8, 1997 and September 4, 1997. (Mean EDM closure error was $0.005 \mathrm{~m}$.)

Overall, the change in elevation was $-6 \pm 4 \mathrm{~mm}$. When the closure error for the EDM survey is considered, the mean change in elevation for the entire barrier is not statistically significant $(\alpha=0.05)$. An examination of the data for extreme changes showed a maximum decrease of $41 \mathrm{~mm}$ that occurred in the northwest corner of the PSB. This region of the barrier has always been the first to experience surface ponding in extreme precipitation conditions. The above-average decrease in this area may have occurred during the last winter when this area remained under water for several days.

The change in elevation between the first survey in December 1994 and the last survey in September, 1997 is shown in Figure 3.7. The darker areas represent an increase in elevation while the lighter areas represent decreases in elevation. Overall, the change in elevation ranged from $-34 \mathrm{~mm}$ to $43 \mathrm{~mm}$ with a mean of $14 \pm 8 \mathrm{~mm}$. The increase in elevation is most likely due to plant activity in the silt loam. Plant roots are usually much larger than the pores present in a compact and relatively structureless soils. Such a structureless condition has existed since soon after construction of the prototype. However, as shown with many crop species, root development encourages soil granulation and the development of a fluffy, porous condition with a subsequent decrease in bulk density. Near-surface measurements of bulk density at the PSB have shown a decrease over the last three years. Localized increases in elevation are also 


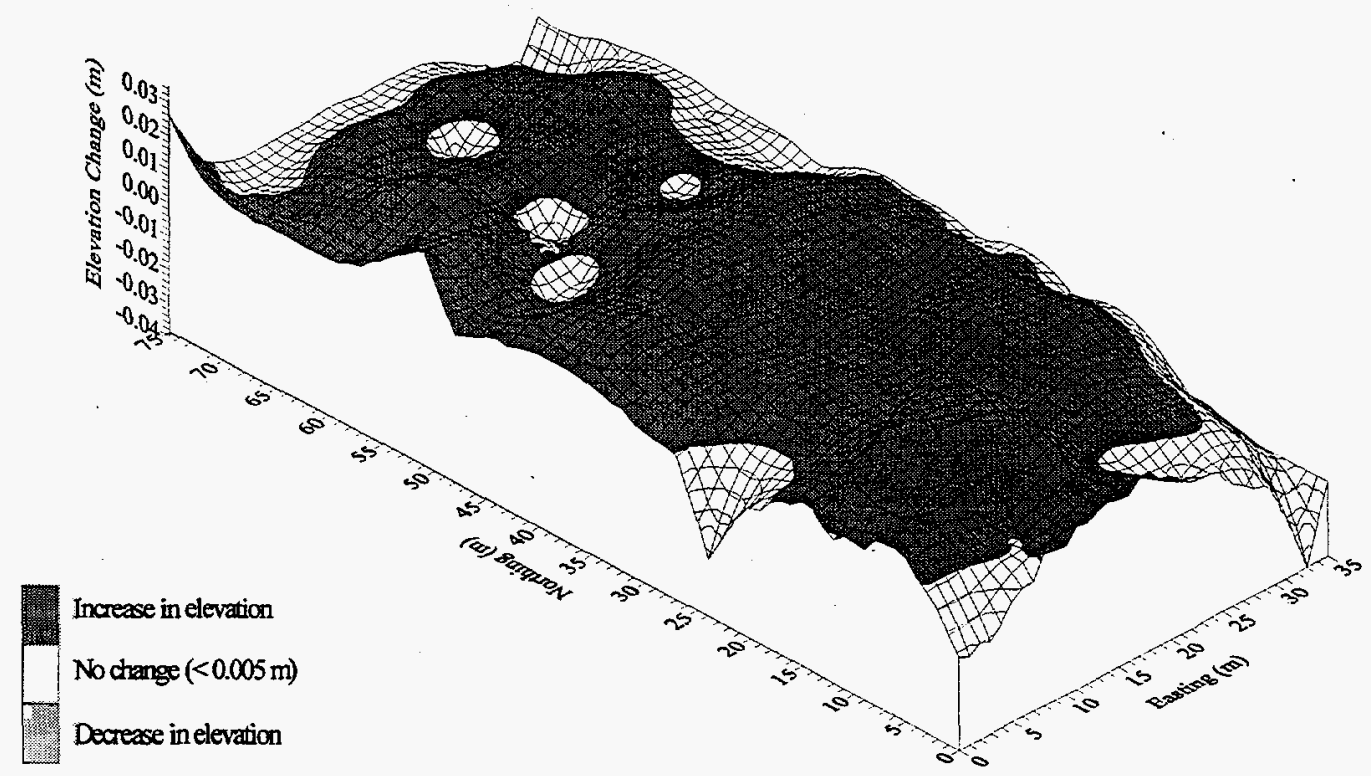

Figure 3.7. Change in Surface Elevation at the Prototype Surface Barrier Between December 16, 1994 and September 4, 1997. (Mean EDM closure error was $0.005 \mathrm{~m}$.)

attributable to other factors. For example, the largest increase in elevation over the three years of monitoring was in the area $60 \mathrm{~m}$ north and $5 \mathrm{~m}$ east of the prototype barrier. This increase was caused by excavation and back fill of the temporary RO test plot (Gee et al. 1996).

\subsubsection{Settlement and Creep Gauge Movement}

The two settlement gauges installed on the top of the asphalt pad have been surveyed twice each year since monitoring started. These gauges are located at the northern end of the PSB and are shown in Figure 1.3. The data for the three years were averaged over the two gauges and corrected for the closure error of each survey. The results are summarized in Figure 3.8. At the time of the last survey, mean change in elevation, after accounting for spatial variability and closure error, was $10 \pm 7 \mathrm{~mm}$, which is not statistically different from the elevation in December 1994. This observation is consistent with the nature of the soils at the site.

The surface and near-surface soils consist of sands of fluvial and eolian origin. Their materials do not characteristically exhibit significant consolidation or compression behavior. While proper compaction of the subsoils during construction would largely eliminate the potential for subsidence, some compression could still be caused by the weight of the barrier materials. Based on the results of the settlement gauge monitoring, no vertical deformation of the subsoils and subsurface barrier material has happened over the last three years. The barrier and subsoils still appear to be stable. 


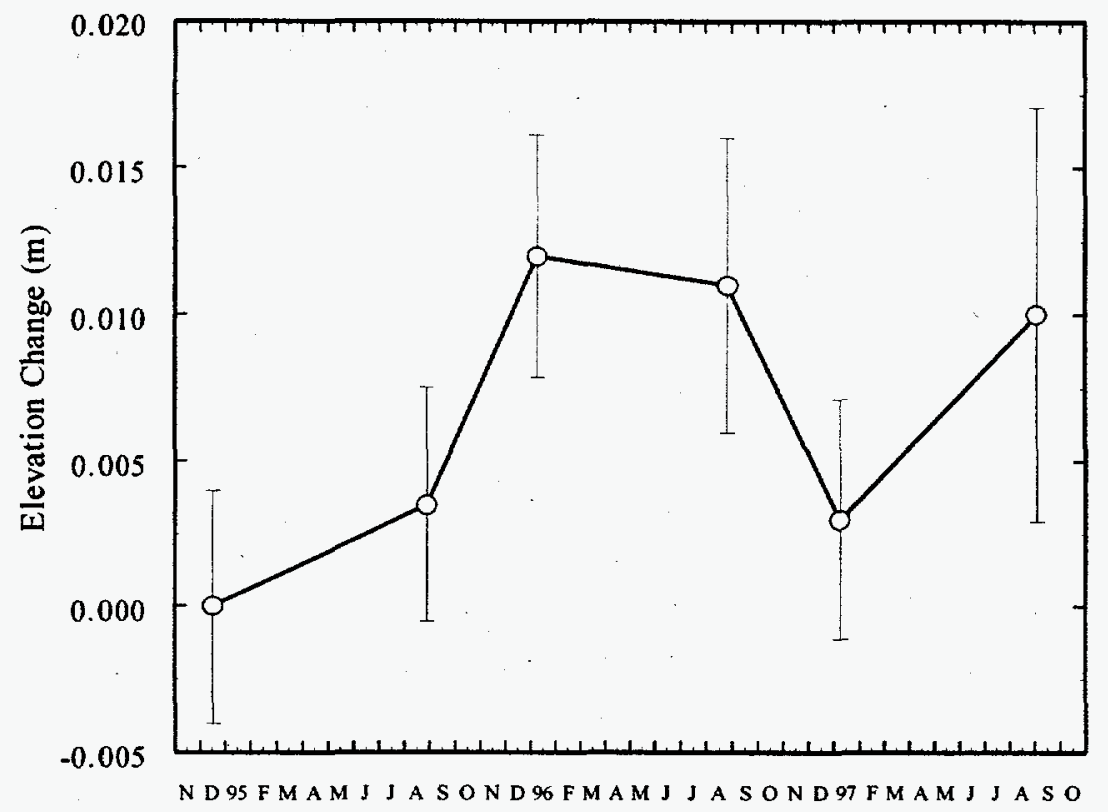

Date

Figure 3.8. Cumulative Summary of Changes in Settlement Gauge Elevation Between November 1, 1994 and September 30, 1997. (No significant change in elevation has occurred in the last three years.)

The location of each creep gauge was also surveyed twice per year over the last three years. The position of each gauge was described by a northing $(x)$, an easting $(y)$, and an elevation $(z)$ from which a displacement vector was calculated. Changes in $x(\Delta x), y(\Delta y)$, and $z(\Delta z)$ since December 1994 were determined. Changes were used to calculate the resultant $(r)$ and bearing $(\Theta)$ of the displacement vector that were then expressed as a polar coordinate $P$, denoted by $(r, \Theta)$. The change in creep gauge location between the two surveys in WY-1997 is shown in Figure 3.9.

Figure 3.10 shows the displacement vector for the creep gauges between December 1994 and September 1997. These data indicate all 12 gauges experienced some small changes in location and elevations. The preferred direction of gauge movement $(\Theta)$ is toward the east, although not all gauges showed statistically significant movement. Gauges CG10a and CG10b, placed at upper and lower slope positions, showed no significant difference in displacement between gauges or between survey dates. The mean distance traveled between the two surveys was $0.014 \pm 0.002 \mathrm{~m}$ in a generally northeasterly direction. When the closure errors for the two surveys in January, $(\Delta x= \pm 0.002 \mathrm{~m} ; \Delta \mathrm{x}= \pm 0.008 \mathrm{~m}$; $\Delta \mathrm{z}= \pm 0.001$; in September, $\Delta \mathrm{x}= \pm 0.012 \mathrm{~m} ; \Delta \mathrm{x}= \pm 0.001 \mathrm{~m} ; \Delta \mathrm{z}= \pm 0.007$ ) are factored into the calculation, the change in the result is not statistically significant.

The movement shown by gauges CG1, CG4, CG9, and CG11 between the two survey dates was statistically significant with CG1 showing the greatest movement of $0.036 \pm 0.015 \mathrm{~m}$ in an easterly direction. The time course of creep gauge movement over the last three years is summarized in Figure 3.11 . 


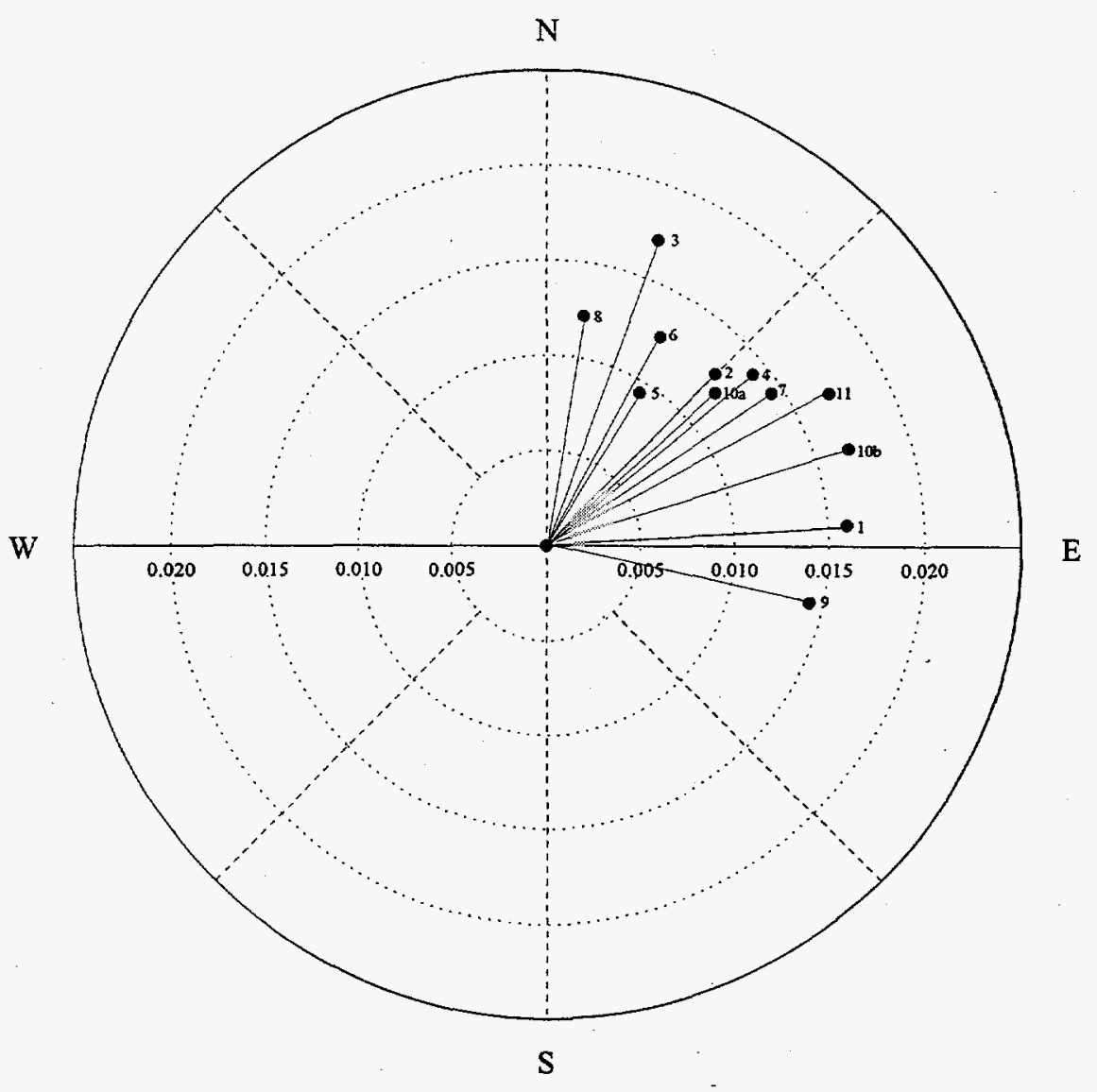

Figure 3.9. Creep Gauge Movement Between January 8, 1997 and September 4, 1997. (Elevation was measured by EDM. The resultant is in meters and the bearing is in radians.)

Individual measurements in each year show a somewhat random movement. However, reduction in the variance of the bearing estimates between the first and last surveys suggest a preferred easterly movement. Unlike the change in bearing between January 1997 and September 1997, the change from August 1996 to September 1997 was statistically significant. Movement in an easterly direction is consistent with an outward and downward movement of the rock slope. However, visual observation and the magnitude of the measured changes show no evidence of side slope failure. Thus, the small amount of displacement observed between December 1994 and September 1997 is most likely due to settlement of the side slope into a more stable and compact arrangement. 


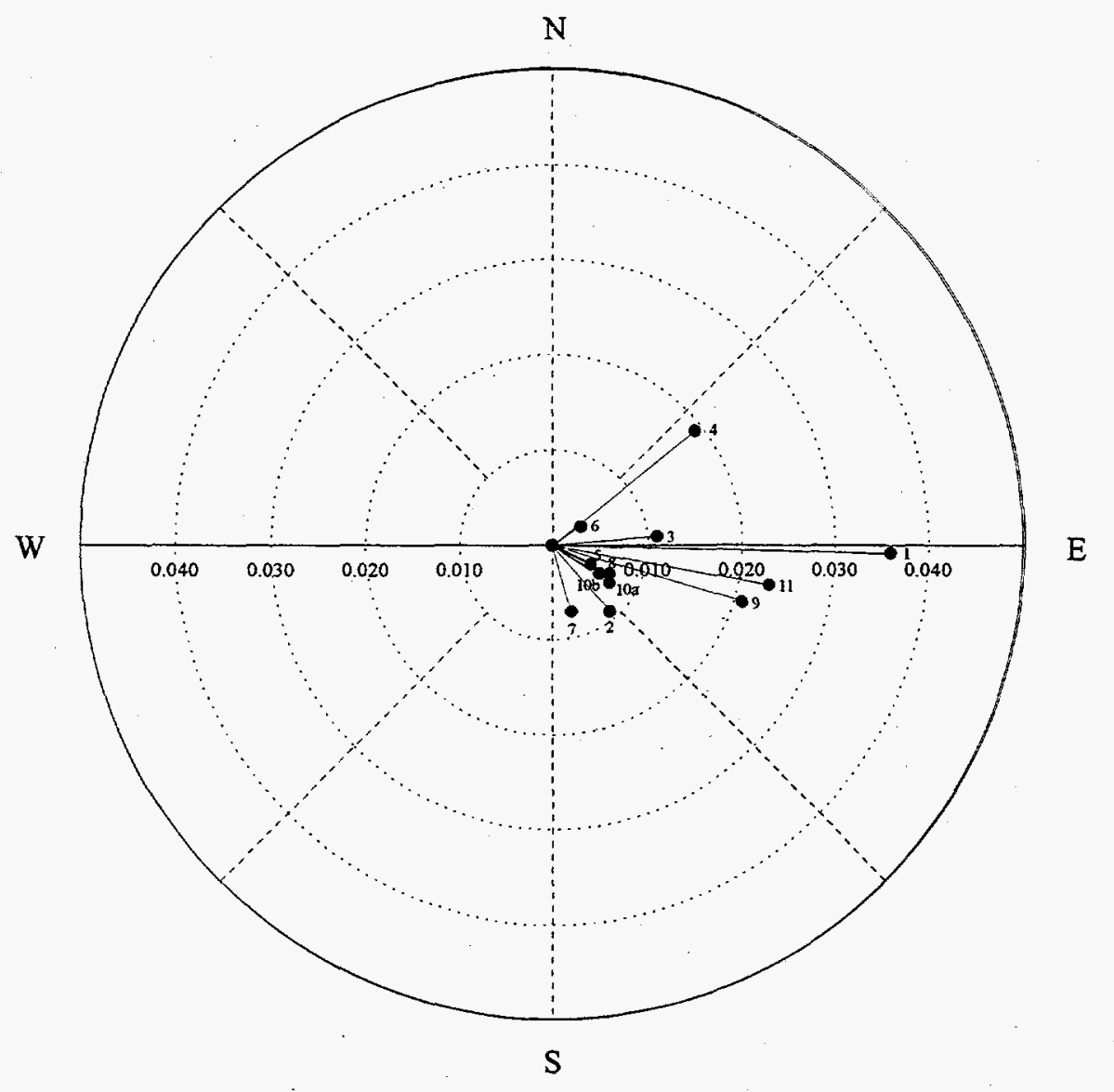

Figure 3.10. Creep Gauge Movement Between December 16, 1994 and September 4, 1997.

(Elevation was measured by EDM. The resultant is in meters and the bearing is in radians.)

\subsection{Summary and Conclusions}

During the last year, testing and monitoring continued toward the goal to quantify the effect of water erosion on barrier stability. As in previous years, the barrier was monitored to quantify surface RO and sediment yield, and to estimate changes in soil physical properties. The surface was surveyed to determine surface elevation, the elevation of settlement gauges, and the location of creep gauges.

Last winter was the wettest on record for the Hanford Site; a combination of rain, heavy snowfall, rapid snowmelt, and frozen soil conditions led to the first RO events observed since the March 1995 1000 -year storm event. The erosivity of the major storm events was generally less than the average annual erosivity index for the Hanford Site and considerably less than events that caused soil erosion in the past. Four major storm events were observed, generating a total of $36.3 \mathrm{~mm}$ of surface RO. The $2 \%$ slope of the surface appears to promote RO without inducing excessive erosional forces. No movement 

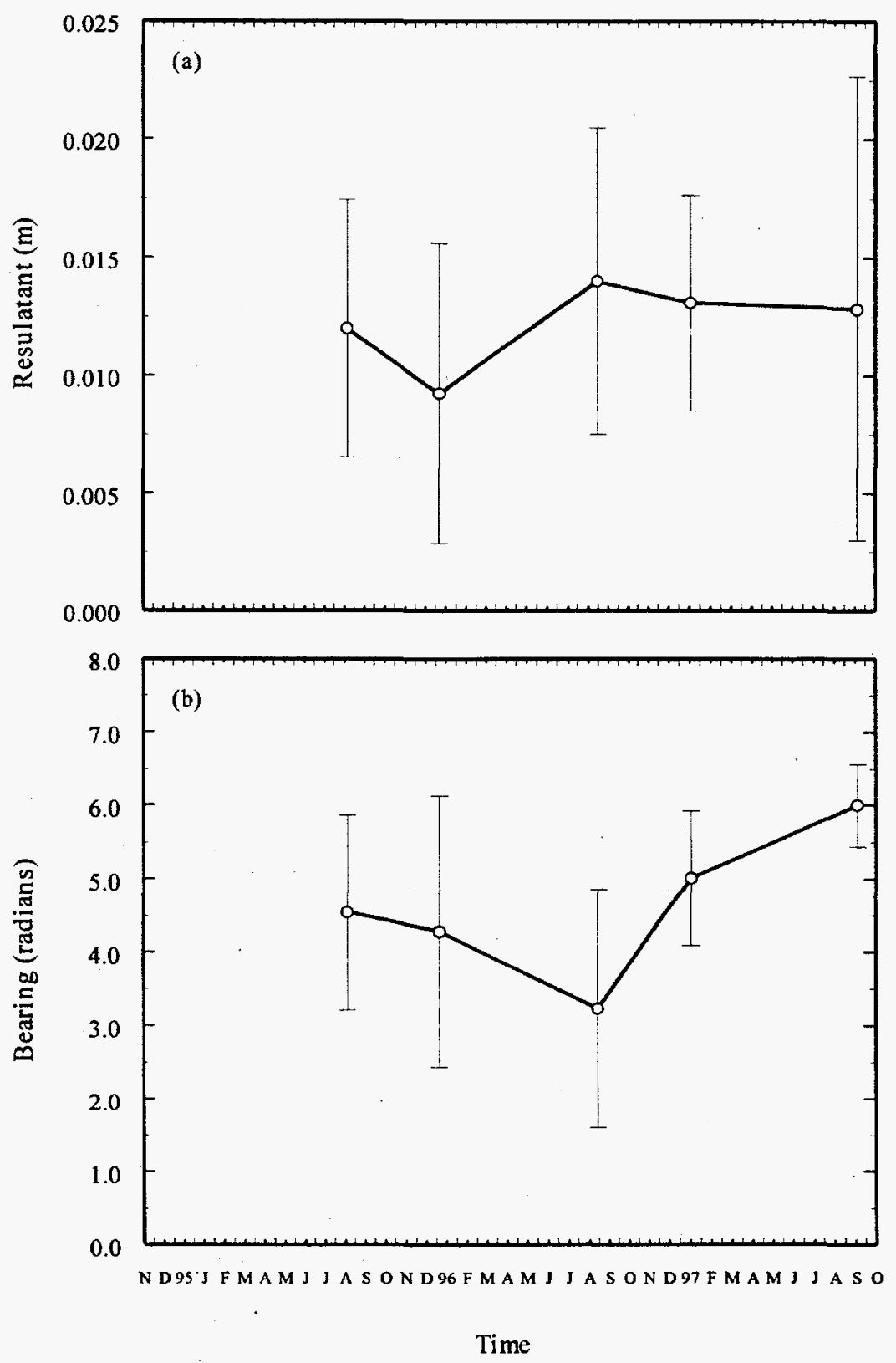

Figure 3.11. Creep Gauge Movement Relative to the First Civil Survey on December 16, 1994, (a) change in resultant, (b) change in bearing. (Error bars represent the standard deviation of the resultant and bearing of the 12 creep gauges.) 
of sediment was observed during the RO events. This observation is indicative of a less erodible soil or a soil that is becoming less vulnerable to erosion.

In FY-1997, mean surface dry density was significantly lower on the irrigated treatment $\left(1673 \pm 39 \mathrm{~kg} \mathrm{~m}^{-3}\right)$, compared to the non-irrigated treatment $\left(1718 \pm 45 \mathrm{~kg} \mathrm{~m}^{-3}\right)$, but the densities showed no differences between plots within treatments. Surface densities have also shown a steady decline over the last three years, decreasing from an initial $1879 \pm 67 \mathrm{~kg} \mathrm{~m}^{-3}$ to $1695 \pm 47 \mathrm{~kg} \mathrm{~m}^{-3}$ by August 1997. During the same period, soil organic matter on the irrigated treatment increased relative to control samples and the non-irrigated plot. The continued decrease in density over the last three years can be attributed to plant root exploration and an increase in soil organic matter content. A decrease in density is usually accompanied by a decrease in permeability that could further reduce susceptibility to erosion by water.

In WY-1997, the main topographic features of the barrier, such as the degree and length of slope, remained unchanged. The elevation change between January 1997 and September 1997 was not statistically significant. However, a general elevation increase was observed relative to the first survey in December 1994. Between December 1994 and September 1997, mean elevation increased by $14 \pm 8 \mathrm{~mm}$. This increase can be attributed to the reduction in bulk density caused by plant root exploration. The settlement gauges embedded in the asphalt layer have shown no significant change in elevation. The absence of vertical deformation is consistent with a stable barrier overlying stable subsoil materials. A survey of the creep gauges located on the rock side slope showed random changes in their results and bearings from year to year. However, overall change between the first and last surveys show the preferred direction of gauge movement is to the east, consistent with an outward and downward movement of the slope. Rather than undergoing failure, the magnitude of the movement suggests the slope is settling into a more compact and stable arrangement.

During the last year, barrier performance has in no way been compromised by water erosional stresses. The vulnerability of the soil to water erosion has decreased over the last three years. The degree and length of the surface slope remains unchanged. In the short term, the fundamental physical characteristics of the soil that govern erodibility are unlikely to change. Thus, the decreasing erodibility is indicative of the effects of surface vegetation. The barrier's surface and side slopes appear to be evolving toward more stable systems. 


\subsection{Wind Erosion}

After water erosion, wind erosion is the second main cause of soil erosion; it can also influence barrier performance through its effect on water storage capacity. The loss of soil from the surface can lead to a reduction in the water-storage capacity, thereby compromising infiltration control. The amount of wind erosion that occurs under a given set of conditions is a function of the ability of the wind to move the soil particles and the ability of the soil to resist the erosive forces of the wind. Therefore, an understanding of the effect of wind erosion on barrier performance requires understanding how erosion is affected by different wind velocities and how it varies for different soil conditions. The Water Erosion task focused on quantifying the influence of eolian stresses on the stability and the functional performance of the silt loam-admixture surface layer of the PSB.

\subsection{Scope and Objectives}

Wind tunnel tests showed the addition of $15 \%$ by weight of pea gravel to the surface silt loam layer effectively minimized erosion by wind (Ligotke 1993). The results of wind tunnel tests on simulated surface layer admixtures provided information that helped design the surface layer of the PSB (Ligotke and Klopfer 1990; Ligotke 1993). Construction of a field-scale PSB at the Hanford Site provided a unique facility for monitoring the effects of wind on surface stability under natural conditions. The PSB also provided a basis for validating the assumptions made during wind tunnel tests. The scope of this task was to determine the impacts of wind erosion on performance at an actual waste site barrier. The main objectives were to monitor the surface layer after construction, as it aged; to measure the actual rates of surface deflation or inflation; to obtain meteorological information about erosive or sheer stresses that impact the barrier, and to obtain information about abrasive sand particle scouring or saltation (DOE 1993). Because wind erosion is restricted to dry soils, measurements of wind erosion parameters have focused on the south, non-irrigated half of the PSB. Maximum erosive stresses were expected in this region and measurements that would most closely represent the worst-case conditions needed for an erosion-resistant design.

\subsection{Wind Erosion Testing and Monitoring Activities}

The amount of soil transported by wind is a function of the erosivity of the wind, and the erodibility of the soil (Hudson 1981),

$$
\text { Erosion }=f(\text { erosivity })(\text { erodibility })
$$


Because high winds can move more and larger soil particles than slower winds, erosivity depends primarily on the wind velocity. The erodibility, or ability of the soil to resist wind erosion, depends on the quantity of vegetation that affects surface roughness; the amount of precipitation; and the soil conditions, especially particle diameter and moisture content. Thus, work performed to meet these objectives focused on measuring the parameters that affect erosivity and erodibility. The PSB was equipped to obtain direct measures of wind velocities and wind boundary layers from which estimates of erosivity and surface roughness were obtained. The erodibility of the silt loam-admixture layer is best quantified by measures of surface composition and surface layer deflation/inflation. The results of the testing and monitoring activities are summarized in subsections 4.2.1 and 4.2.2.

\subsubsection{Wind Stress Monitoring}

Eolian erosive forces are created by the air flowing over the barrier surface. Measurement of these stresses validate the wind tunnel data used in designing the erosion-resistant surface layer. These data also permit estimation of erosivity and, thus, the effect of eolian stress on the barrier during wind storms. In WY-1997, measurements were made in the top surface south of the center, in the southeast quadrant, and the south southwest of the prototype barrier. The sheer stress parameters of interest are friction velocity $\left(u_{*}\right)$ and roughness height $\left(z_{0}\right)$. The $u_{*}$ represents a characteristic flow velocity and relates to the effectiveness of turbulent exchange over the surface. The $z_{0}$ is a measure of the aerodynamic roughness of the surface where the wind speed profile is measured. These parameters were calculated from measurements of wind velocity gradients (change in wind velocity with elevation) near the surface, using the following relationship:

$$
u_{*}=k \Delta u / \ln \left(z_{1} / z_{2}\right)=k M^{-1}
$$

where

$$
\begin{aligned}
& u_{*}=\text { friction velocity, }\left(\mathrm{m} \mathrm{s}^{-1}\right) \\
& z_{1}=\text { elevation } 1,(\mathrm{~m}) \\
& z_{2}=\text { elevation } 2,(\mathrm{~m}) \\
& \Delta \mathrm{u}=\text { change in velocity between elevations } \mathrm{z}_{1} \text { and } \mathrm{z}_{2},(\mathrm{~m}) \\
& \mathrm{k}=\text { von Karman's constant, usually } 0.40 \\
& \mathrm{M}=\Delta \mathrm{u} / \ln \left(\mathrm{z}_{1} / \mathrm{z}_{2}\right)
\end{aligned}
$$

WY-1997 was generally characterized by normal wind. Data from the PSB show an average wind speed of $3.06 \mathrm{~m} \mathrm{~s}^{-1}$ on the elevated surface, and $2.5 \mathrm{~m} \mathrm{~s}^{-1}$ adjacent to the barrier, compared to a normal wind speed of $3.4 \mathrm{~m} \mathrm{~s}^{-1}$ for the Hanford Site. These data represent measurements at an elevation of 2.0 $\mathrm{m}$. The peak gust during the year was $20.8 \mathrm{~m} \mathrm{~s}^{-1}$ from the east southeast on March 30. At the HMS, peak gusts were $27.6 \mathrm{~m} \mathrm{~s}^{-1}$ from the south-southeast on March $30 ; 22.8 \mathrm{~m} \mathrm{~s}^{-1}$ from the southwest on April $20 ; 20.52 \mathrm{~m} \mathrm{~s}^{-1}$ from the southwest on June 28; and $22.8 \mathrm{~m} \mathrm{~s}^{-1}$ from the southwest on August 26. On 64 days, wind gusts at the PSB exceeded the annual HMS average of $11.6 \mathrm{~m} \mathrm{~s}^{-1}$. Of these 64 days, 6 days 
had peak gusts exceeding $18 \mathrm{~m} \mathrm{~s}^{-1}$. In general, peak wind gusts at the 2-m level on Station 01 were significantly higher than at Stations 02 and 03. In WY-1997, the mean peak gust at Station 01 was $11.27 \pm 1.86 \mathrm{~m} \mathrm{~s}^{-1}$ compared to $10.86 \pm 1.84 \mathrm{~m} \mathrm{~s}^{-1}$ at Station 02 and $11.06 \pm 1.50 \mathrm{~m} \mathrm{~s}^{-1}$ at Station 03 . The difference in wind velocities between these stations is due to surface changes, such as surface roughness. Because Station 03 is at a lower elevation (off the barrier surface) and the native plants are somewhat taller, lower velocities are expected, due to increased drag on the airflow.

A malfunctioning anemometer at Station 03 on March 30 prevented the use of these data to estimate stress parameters. Instead, boundary layer profiles recorded on September 24, 1997 were used to estimate wind stress parameters. These data were used to calculate the surface sheer stress parameters according to Eq. (4.2). The observed and fitted profiles are shown in Figure 4.1. At Station 02, peak wind gust at the 2-m level was $14.7 \mathrm{~m} \mathrm{~s}^{-1}$, compared to $14.05 \mathrm{~m} \mathrm{~s}^{-1}$ at Station 01 and $11.73 \mathrm{~m} \mathrm{~s}^{-1}$ at Station 03 .

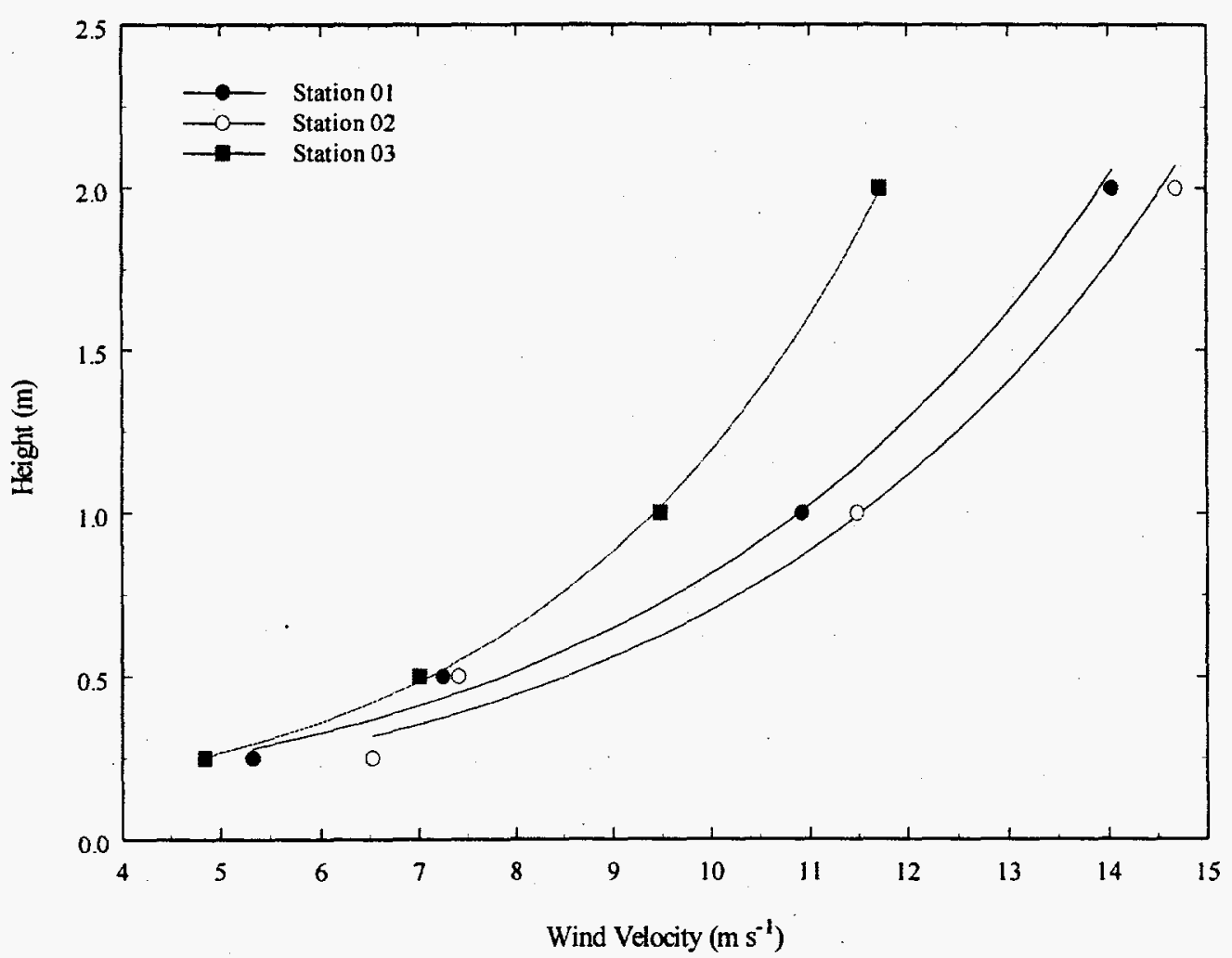

Figure 4.1. Typical Wind Profiles Over the Barrier Site Measured on September 24, 1997. (Station 01 and Station 02 are on the elevated barrier surface, and Station 03 is at ground level. Calculated wind stress parameters over the surface were $\overline{\mathrm{z}_{\mathrm{o}}}=0.076 \pm 0.006 \mathrm{~m}$ and $\overline{\mathrm{u}}_{\mathrm{t}}=0.092 \pm 0.0003 \mathrm{~m} \mathrm{~s}^{-1}$.) 
The mean friction velocity $\left(\bar{u}_{*}\right)$ was $0.092 \pm 0.0003 \mathrm{~m} \mathrm{~s}^{-1}$ on the surface of the PSB, based on the September 24, 1997 data. This velocity is quite similar to the $\bar{u}_{*}$ of $0.076 \pm 0.004 \mathrm{~m} \mathrm{~s}^{-1}$ from March 30 , 1997 , but significantly smaller than the $0.167 \pm 0.005 \mathrm{~m} \mathrm{~s}^{-1}$ calculated from WY-1994 data. These results are somewhat lower than those reported in the literature. Sehmel $(1980,1984)$ reported $u_{*}$ of 1.81 $\mathrm{m} \mathrm{s}^{-1}$ at a height of $2 \mathrm{~m}$ above level desert surfaces. Ligotke (1993) reported $\mathrm{u}$. between 0.4 and $2.2 \mathrm{~m} \mathrm{~s}^{-1}$ for bare silt loam admixtures in wind tunnel tests. The current results also show a significant reduction with time. The reduction in $\mathrm{u}_{*}$ is related to an increase in the effectiveness of turbulent exchange over the surface and is consistent with increases in vegetative cover and plant height. The effect of plant cover on boundary layer profiles becomes more clear by calculating $z_{\mathbf{o}}$.

\subsubsection{Mean Roughness Height}

The mean roughness height $\left(\bar{z}_{0}\right)$, calculated from the September 24 data, was $0.076 \pm 0.006 \mathrm{~m}$, compared to $0.0013 \pm 0.0001 \mathrm{~m}$ in WY-1994. As expected, $\mathrm{z}_{\mathrm{o}}$ was somewhat higher at Station 01 $(0.082 \mathrm{~m})$ than at Station $02(0.070 \mathrm{~m})$ in WY-1997, but both $\mathrm{z}_{\mathrm{o}}$ were identical in WY-1994. These results are somewhat higher than those reported in the literature. For level desert surfaces, Sehmel $(1980,1984)$ reported a typical surface roughness height of $0.0003 \mathrm{~m}$ at a height of $2 \mathrm{~m}$ above the surface. Ligotke (1993) calculated $z_{0}$ of $0.0005 \pm 0.0002 \mathrm{~m}$ in wind tunnel tests on bare surface construction materials. As $z_{0}$ is controlled mainly by surface vegetation, comparison with field and laboratory measurements without plants, or with plants having dissimilar characteristics, can be misleading. A more useful validation is accomplished by estimating the plant height from $z_{0}$ and comparing the results with measured values.

In general, $\mathrm{z}_{\mathrm{o}}$ for plants is about an order of magnitude smaller than the plant height, $h$. The empirical relationship between $z_{0}$ and $h$ reported by Szeicz et al. (1969) was rearranged to give $h$ as a function of $\mathbf{z}_{0}$

$$
h=\exp \left(1.003 \ln z_{o}+2.039\right)
$$

where $h$ and $\mathrm{z}_{\mathrm{o}}$ are in meters. Mean plant height estimated from $\mathrm{z}_{\mathrm{o}}$ at Stations 01 and 02 was $0.58-0.05 \mathrm{~m}$, compared to $0.54 \pm 0.11 \mathrm{~m}$, obtained by averaging the height of Chrysothamnus nauseosus (Gray rabbitbrush) and Artemisia tridentata (Big sagebrush) in the non-irrigated treatment (see subsection 5.1.3.1). If the results of Station 02 are excluded, due to its proximity to the edge of the barrier, and only the dominant Artemisia tridentata is considered in the comparison, the results are even higher. Plant height estimated from $\mathrm{z}_{\mathrm{o}}$ is then $0.63 \mathrm{~m}$ compared to $0.65 \mathrm{~m}$ measured on the non-irrigated treatment. A similar analysis for data collected soon after barrier construction, and before restoration, gives a $\mathrm{z}_{\mathrm{o}}$ of $0.0012 \mathrm{~m}$ and $h$ of $0.088 \mathrm{~m}$ on the surface. These values are comparable to those observed by Ligotke (1993).

For any given soil condition, the amount of soil that is transported by wind depends partly on the 
wind velocity and partly on the roughness height. Roughness height is controlled mainly by vegetation; soil is almost immune to wind erosion when covered with vegetation. The decrease in $u_{*}$ and the increase in $\mathrm{z}_{0}$ and $h$ with time is consistent with an increase in plant cover and plant height. The only measurable soil loss by wind erosion occurred in the first three months after construction. Thus, the changes in the wind stress parameters over time and the associated decrease in soil loss suggest the evolution of a more stable barrier surface. Field-measured $u_{*}$ and $z_{0}$ allow more accurate predictions of wind profiles above vegetated barrier surfaces than are possible with wind tunnel data.

\subsubsection{Surface Layer Composition}

During construction of the prototype barrier in WY-1994, the top $1 \mathrm{~m}$ of the silt-loam surface layer was amended through the addition of $15 \%$ by weight of pea gravel. The gravel was added to decrease the erosion vulnerability of the soil. The decision to use a $15 \%$ admixture was a compromise between the need for a medium to support plant growth, for water storage, and for resistance to erosion (Ligotke and Klopfer 1990; Ligotke 1993). Immediately after construction in WY-1994, 24 soil samples were taken from the surface to determine its composition (Gee et al. 1994). The soil samples were obtained by coring the soil column down to a depth of $10 \mathrm{~cm}$. In this report, they are referred to as bulk samples. In subsequent years, soil samples were obtained by coring the soil column from 0 to $2 \mathrm{~cm}$ (surface samples) and from 2 to $10 \mathrm{~cm}$ (bulk samples). Samples were taken to the laboratory where wet and dry weights were used to calculate pea gravel content before and after sieving $(0.33-\mathrm{cm}$ sieve). Because less than 30 samples were taken at each sampling, the data were analyzed using small sample theory, assuming unequal variances, to identify spatial and temporal differences. Temporal changes in surface composition provide a good measure of changes in erodibility.

\subsubsection{Pea Gravel Content in Bulk and Surface Samples}

Near-surface $(0-2 \mathrm{~cm})$ and bulk gravel $(0-10 \mathrm{~cm})$ contents by weight on a dry weight basis from the last 3 years of testing are summarized in Table 4.1. The Student's $t$-test was used to test the hypothesis stating that means from two small samples are equal. This approach was used to identify the differences between plots within precipitation treatments, between treatments, and between sampling dates. In WY1994, mean gravel content for the entire barrier was $16.2 \pm 3.0 \%$ by weight. Mean gravel content on the irrigated treatment was $16.9 \pm 4.0 \%$ by weight, which was not significantly different $(\alpha=0.05)$ from the $15.5 \pm 1.0 \%$ by weight observed on the non-irrigated treatment. Differences between plots within treatments could not be determined, as not all samples from the first sampling were analyzed. In WY1997, mean gravel content for the entire barrier was $13.4 \pm 2.0 \%$ by weight, which was no different than the $13.0 \pm 1.5 \%$ by weight observed in WY-1996. However, the WY-1997 value was significantly smaller than the WY-1994 value $(\alpha=0.05)$. The 1997 results showed no differences between plots within treatments or between treatments. However, the treatment differences between WYWY-1994 and WY1997 were significant with the irrigated treatment showing the greatest decline in gravel content. 
Table 4.1. Mean \% Pea Gravel Content $(\bar{G})$ and the Standard Deviation of the Mean $\left(\sigma_{\bar{G}}\right)$ of NearSurface $(0-2 \mathrm{~cm})$ and Bulk Samples $(0-10 \mathrm{~cm})$ Obtained from the Prototype Surface Barrier. (Gravel content is reported on a dry weight basis. Samples were taken in August of each year, except in WY-1995 when samples were taken in April. NA = not available.)

\begin{tabular}{|c|c|c|c|c|c|c|c|c|c|}
\hline \multirow[b]{2}{*}{ Plot } & \multirow[b]{2}{*}{$\begin{array}{l}\text { Depth } \\
(\mathrm{cm})\end{array}$} & \multicolumn{2}{|c|}{ WY-1994(a) } & \multicolumn{2}{|c|}{ WY-1995 } & \multicolumn{2}{|c|}{ WY-1996 } & \multicolumn{2}{|c|}{ WY-1997 } \\
\hline & & $\overline{\mathrm{G}}(\%)$ & $\sigma_{\bar{G}}(\%)$ & $\overline{\mathrm{G}}(\%)$ & $\sigma_{\bar{G}}(\%)$ & $\bar{G}(\%)$ & $\sigma_{\bar{G}}(\%)$ & $\bar{G}(\%)$ & $\sigma_{\overline{\mathrm{G}}}(\%)$ \\
\hline \multirow[t]{2}{*}{$\mathrm{NE}$} & $0-2$ & NA & NA & 14.8 & 2.2 & 12.1 & 2.6 & 12.6 & 2.1 \\
\hline & $0-10$ & 16.8 & 4.0 & 12.6 & 1.4 & 12.6 & 1.9 & 14.2 & 2.2 \\
\hline \multirow[t]{2}{*}{ NW } & $0-2$ & NA & NA & 15.1 & 2.0 & 12.5 & 3.6 & 11.5 & 2.1 \\
\hline & $0-10$ & NA & NA & 12.6 & 1.2 & 12.8 & 1.8 & 12.6 & 2.5 \\
\hline \multirow[t]{2}{*}{ Irrigated $^{(\mathbf{b})}$} & $0-2$ & NA & NA & 14.9 & 2.1 & 12.3 & 3.2 & 12.0 & 2.2 \\
\hline & $0-10$ & 16.9 & 4.0 & 12.6 & 1.3 & 12.8 & 1.8 & 13.4 & 2.5 \\
\hline \multirow[t]{2}{*}{ SE } & $0-2$ & NA & NA & 15.7 & 3.2 & 11.5 & 1.4 & 14.5 & 1.9 \\
\hline & $0-10$ & NA & NA & 13.6 & 1.0 & 13.2 & 0.9 & 13.3 & 0.9 \\
\hline \multirow[t]{2}{*}{ SW } & $0-2$ & - & - & 13.6 & 1.5 & 14.4 & 2.4 & 13.5 & 2.2 \\
\hline & $0-10$ & 15.5 & 1.0 & 12.5 & 1.1 & 13.3 & 1.0 & 13.4 & 1.4 \\
\hline \multirow{2}{*}{$\begin{array}{l}\text { Non- } \\
\text { irrigated }^{(c)}\end{array}$} & $0-2$ & - & - & 14.6 & 2.7 & 12.9 & 2.5 & 14.0 & 2.1 \\
\hline & $0-10$ & 15.5 & 1.0 & 13.1 & 1.2 & 13.3 & 1.0 & 13.3 & 1.2 \\
\hline
\end{tabular}

(a) WY-1994 was during construction and there was no testing and monitoring except coring. Cores taken in WY1994 were from 0-8 $\mathrm{cm}$ depth and were not differentiated into surface and bulk samples.

(b) Bolded rows contain averages from data in the preceding columns for Plots NE and NW.

(c) Bolded rows contain averages from data in the preceding columns for Plots SE and SW.

Two of the main issues raised in extrapolating the results of laboratory and wind tunnel tests on admixture composition to a field-scale barrier included 1) the practicality of deploying an admixture at the field scale, and 2) whether a uniform admixture composition could be maintained throughout the life of the barrier. During the construction, no unforseen practical difficulties were encountered and the required composition was achieved within experimental limits. Bulk gravel content has remained unchanged over the last two years, although it declined from WY-1994 to WY-1995 when surface cover was limited. Considering the small increase in organic carbon content (see subsection 3.2.3.1), these changes become less significant. Thus, an uniform admixture composition of $15 \mathrm{wt} \% \mathrm{can}$ be placed and maintained at the field-scale without any short-term impacts on plant growth or water storage. While changes in the composition of the admixture layer are not expected in the short term, near-surface $(0-2 \mathrm{~cm})$ changes are quite possible. The near-surface samples were analyzed to determine whether any changes in composition occurred. 
In the short-term, the ability of the silt loam admixture to resist erosion is best determined by recording the amount of surface inflation or deflation. During deflationary periods, the pea gravel content at the surface is expected to increase and form an armor as soil particles are removed by wind. Under such conditions, the pea gravel content in the top few inches of soil could be expected to increase relative to its bulk distribution in the soil layer. During inflationary periods, a layer of soil that is largely free of pea gravel is expected to form on the surface and the gravel content in the top few centimeters of soil could be expected to decrease, relative to its bulk distribution in the soil layer.

At the time of first sampling in August WY-1994, no surface samples (0-2 cm) were taken. Results from August 1995 show a $\overline{\mathrm{G}}$ content of $14.8 \pm 2.4 \%$ by weight averaged over the entire surface. No significant differences were noted between plots within treatments or between treatments. In WY-1997, mean gravel content in the $0-2 \mathrm{~cm}$ layer for the entire surface was $13.0 \pm 2.3 \%$ by weight, which was no different from the WY-1995 values. At the treatment level, $\overline{\mathrm{G}}$ was $12.0 \pm 2.2 \%$ on the irrigated treatment, which was slightly smaller than the $14.0 \pm 2.1 \%$ by weight observed on the non-irrigated treatment in WY-1997. The mean surface gravel content decreased from $14.9 \pm 2.1 \%$ by weight in WY1995 to $12.3 \pm 3.2 \%$ by weight in WY-1997. The amount of gravel in the $0-2 \mathrm{~cm}$ depth, relative to the $2-$ $10 \mathrm{~cm}$ depth, also decreased from WY-1995 to WY-1997. On average, the ratio decreased from 1.15 to 0.97. At the plot level, the decrease was greater on the northeast, irrigated plot where the ratio decreased from 1.17 to 0.88 . The decrease in surface gravel $(0-2 \mathrm{~cm})$, particularly on the irrigated treatments, suggests either gravel loss by erosion or surface inflation. The erosivity of rainstorms at the barrier was insufficient to move pea gravel over any considerable distance (subsection 3.2.1) and, therefore, rules out erosion. However, a measurable increase has occurred in the $\% \mathrm{C}$ in the surface soil and an increase in plant debris on the surface, particularly in the irrigated treatment (subsection 3.2.3.1). These changes are the most likely cause of the apparent changes in pea gravel content. It is expected that most of the short term changes will occur in the near-surface layers, with changes in bulk gravel content occurring only in the long-term or after severe erosional stresses.

\subsubsection{Dry Soil Density of Bulk and Surface Samples}

The soil cores were also used to calculate dry densities for the admixture and silt loam. Dry densities for the admixture are summarized in Table 4.2. In WY-1997, the admixture dry density of the bulk samples, averaged over the PSB, was $1503 \pm 117 \mathrm{~kg} \mathrm{~m}^{-3}$. The mean density is essentially the same as that measured in WY-1996, but significantly smaller than the $2053 \pm 117 \mathrm{~kg} \mathrm{~m}^{-3}$ measured in WY-1994. Differences between plots with treatments and between treatments themselves were not significant at $\alpha=0.05$. This result is essentially the same as observed in previous years. The absolute densities of the bulk samples are somewhat smaller than those measured by the neutron density gauge and reported in subsection 3.2.3.1. However, the temporal trend is the same, suggesting the difference between the two data sets may be a reflection of measurement technique and measurement error. The densities measured in the $0-2 \mathrm{~cm}$ layer also appear quite high. In addition, the standard deviations are quite high when compared to the $0-10 \mathrm{~cm}$ samples. The unusually large values of the mean and standard deviation are probably due to a combination of sampling technique and measurement error. 
Table 4.2. Mean Admixture Dry Densities, $\bar{\rho}_{\mathrm{b}}$ and the Standard Deviation of the Mean $\left(\sigma_{\bar{\rho}}\right)$ of NearSurface $(0-2 \mathrm{~cm})$ and Bulk Samples $(0-10 \mathrm{~cm})$ Obtained from the Prototype Surface Barrier. (Samples were taken in August of each year, except in WY-1995 when samples were taken in April. NA = not available.)

\begin{tabular}{|c|c|c|c|c|c|c|c|c|c|}
\hline \multirow[b]{2}{*}{ Plot } & \multirow[b]{2}{*}{$\begin{array}{l}\text { Depth } \\
\text { (cm) }\end{array}$} & \multicolumn{2}{|c|}{ WY-1994(a) } & \multicolumn{2}{|c|}{ WY-1995 } & \multicolumn{2}{|c|}{ WY-1996 } & \multicolumn{2}{|c|}{ WY-1997 } \\
\hline & & $\begin{array}{c}\overline{\rho_{\mathrm{b}}} \\
\left(\mathrm{kg} \mathrm{m}^{-3}\right)\end{array}$ & $\begin{array}{c}\sigma_{\bar{G}} \\
\left(\mathrm{~kg} \mathrm{~m}^{-3}\right)\end{array}$ & $\begin{array}{c}\overline{\rho_{\mathrm{b}}} \\
\left(\mathrm{kg} \mathrm{m}^{-3}\right)\end{array}$ & $\begin{array}{c}\sigma_{\overline{\mathrm{G}}} \\
\left(\mathrm{kg} \mathrm{m}^{-3}\right)\end{array}$ & $\begin{array}{c}\overline{\rho_{\mathrm{b}}} \\
\left(\mathrm{kg} \mathrm{m}^{-3}\right)\end{array}$ & $\begin{array}{c}\sigma_{\bar{G}} \\
\left(\mathrm{~kg} \mathrm{~m}^{-3}\right)\end{array}$ & $\begin{array}{c}\bar{\rho}_{\mathrm{b}} \\
\left(\mathrm{kg} \mathrm{m}^{-3}\right)\end{array}$ & $\begin{array}{c}\sigma_{\overline{\mathrm{G}}} \\
\left(\mathrm{kg} \mathrm{m}^{-3}\right)\end{array}$ \\
\hline \multirow[t]{2}{*}{ NE } & $0-2$ & $\mathrm{NA}$ & $\mathrm{NA}$ & 1670 & 203 & 1740 & 254 & 1664 & 321 \\
\hline & $0-10$ & 1983 & 46 & 1542 & 69 & 1474 & 63 & 1468 & 92 \\
\hline \multirow[t]{2}{*}{ NW } & $0-2$ & NA & $\mathrm{NA}$ & 1826 & 169 & 1896 & 343 & 1830 & 215 \\
\hline & $0-10$ & NA & NA & 1614 & 78 & 1460 & 123 & 1488 & 73 \\
\hline \multirow[t]{2}{*}{ Irrigated $^{(b)}$} & $0-2$ & NA & NA & 1748 & 202 & 1818 & 312 & 1747 & 286 \\
\hline & $0-10$ & 1983 & 46 & 1578 & 82 & 12.8 & 1.8 & 1478 & 84 \\
\hline \multirow[t]{2}{*}{ SE } & $0-2$ & $\mathrm{NA}$ & NA & 1866 & 361 & 1704 & 184 & 1686 & 409 \\
\hline & $0-10$ & NA & NA & 1561 & 104 & 1725 & 68 & 1530 & 91 \\
\hline \multirow[t]{2}{*}{ SW } & $0-2$ & NA & NA & 1900 & 258 & 1827 & 137 & 1788 & 234 \\
\hline & $0-10$ & 2123 & 105 & 1479 & 78 & 1735 & 73 & 1525 & 61 \\
\hline \multirow{2}{*}{$\begin{array}{l}\text { Non- } \\
\text { irrigated }^{(\mathrm{c})}\end{array}$} & $0-2$ & NA & NA & 1833 & 314 & 1766 & 173 & 1737 & 337 \\
\hline & $0-10$ & 2123 & 105 & 1520 & 101 & 1730 & 70 & 1527 & 77 \\
\hline
\end{tabular}

(a) WY-1994 was during construction and there was no testing and monitoring except coring. Cores taken in WY1994 were from 0-8 cm depth and were not differentiated into surface and bulk samples.

(b) Bolded rows contain averages from data in the preceding columns for Plots NE and NW.

(c) Bolded rows contain averages from data in the preceding columns for Plots SE and SW.

Changes in near-surface silt loam density could signal changes in surface composition caused by erosion or by inflationary/deflationary processes. Dry densities for the silt loam, that is, the admixture from which the pea gravel had been removed by sieving, are summarized in Table 4.3. The mean silt loam dry density in WY-1997 was $1511 \pm 291 \mathrm{~kg} \mathrm{~m}^{-3}$, which was not significantly different from the $1558 \pm 216 \mathrm{~kg} \mathrm{~m}^{-3}$ observed in 1996. Because no surface measurements $(0-2 \mathrm{~cm})$ were taken in WY1994, no comparison can be made between WY-1997 and WY-1994 data. The WY-1997 data were compared with those from WY-1995 and showed no difference. These results contradict the pea gravel content data. A decrease in surface pea gravel content and in the ratio of surface to bulk gravel content was observed between 1995 and 1997 (subsection 4.2.2.1). This ratio suggested a loss of gravel or an increase in the non-gravel component. 
Table 4.3. Mean Silt Loam Dry Densities, $\overline{\rho_{b}}$ and the Standard Deviation of the Mean $\left(\sigma_{\bar{\rho}}\right)$ of NearSurface (0-2 cm) and Bulk Samples $(0-10 \mathrm{~cm})$ Obtained from the Prototype Surface Barrier. (Samples were taken in August of each year, except in WY-1995 when samples were taken in April. NA = not available.)

\begin{tabular}{|c|c|c|c|c|c|c|c|c|c|}
\hline \multirow[b]{2}{*}{ Plot } & \multirow[b]{2}{*}{$\begin{array}{c}\text { Depth } \\
(\mathrm{cm})\end{array}$} & \multicolumn{2}{|c|}{ WY-1994(a) } & \multicolumn{2}{|c|}{ WY-1995 } & \multicolumn{2}{|c|}{ WY-1996 } & \multicolumn{2}{|c|}{ WY-1997 } \\
\hline & & $\begin{array}{c}\overline{\rho_{b}} \\
\left(\mathrm{~kg} \mathrm{~m}^{-3}\right)\end{array}$ & $\begin{array}{c}\sigma_{\overline{\mathrm{G}}} \\
\left(\mathrm{kg} \mathrm{m}^{-3}\right)\end{array}$ & $\begin{array}{c}\overline{\rho_{\mathrm{b}}} \\
\left(\mathrm{kg} \mathrm{m}^{-3}\right)\end{array}$ & $\begin{array}{c}\sigma_{\bar{\sigma}} \\
\left(\mathrm{kg} \mathrm{m}^{-3}\right)\end{array}$ & $\begin{array}{c}\bar{\rho}_{\mathrm{b}} \\
\left(\mathrm{kg} \mathrm{m}^{-3}\right)\end{array}$ & $\begin{array}{c}\sigma_{\overline{\mathrm{G}}} \\
\left(\mathrm{kg} \mathrm{m}^{-3}\right)\end{array}$ & $\begin{array}{c}\overline{\rho_{\mathrm{b}}} \\
\left(\mathrm{kg} \mathrm{m}^{-3}\right)\end{array}$ & $\begin{array}{c}\sigma_{\overline{\mathrm{G}}} \\
\left(\mathrm{kg} \mathrm{m}^{-3}\right)\end{array}$ \\
\hline \multirow[t]{2}{*}{ NE } & $0-2$ & NA & $\mathrm{NA}$ & 1420 & 155 & 1521 & 219 & 1445 & 287 \\
\hline & $0-10$ & 1983 & 46 & 1320 & 61 & 1278 & 58 & 1244 & 64 \\
\hline \multirow[t]{2}{*}{ NW } & $0-2$ & $\mathrm{NA}$ & $\mathrm{NA}$ & 1553 & 168 & 1646 & 271 & 1612 & 208 \\
\hline & $0-10$ & $\mathrm{NA}$ & $\mathrm{NA}$ & 1381 & 54 & 1263 & 93 & 1289 & 51 \\
\hline \multirow[t]{2}{*}{ Irrigated $^{(\mathbf{b})}$} & $0-2$ & NA & NA & 1487 & 174 & 1584 & 254 & 1528 & 264 \\
\hline & $0-10$ & 1983 & 46 & 1350 & 65 & 1271 & 78 & 1267 & 62 \\
\hline \multirow[t]{2}{*}{ SE } & $0-2$ & NA & NA & 1579 & 332 & 1507 & 176 & 1443 & 370 \\
\hline & $0-10$ & NA & NA & 1333 & 88 & 1493 & 57 & 1323 & 83 \\
\hline \multirow[t]{2}{*}{ SW } & $0-2$ & $\mathrm{NA}$ & $\mathrm{NA}$ & 1640 & 213 & 1559 & 116 & 1544 & 207 \\
\hline & $0-10$ & 2123 & 105 & 1279 & 74 & 1500 & 70 & 1318 & 57 \\
\hline \multirow{2}{*}{$\begin{array}{l}\text { Non- } \\
\text { irrigated }^{(c)}\end{array}$} & $0-2$ & NA & NA & 1610 & 280 & 1533 & 152 & 1493 & 304 \\
\hline & $0-10$ & 2123 & 105 & 1306 & 86 & 1497 & 64 & 1320 & 71 \\
\hline
\end{tabular}

(a)WY-1994 was during construction and there was no testing and monitoring except coring. Cores taken in WY1994 were from 0-8 cm depth and were not differentiated into surface and bulk samples.

(b) Bolded rows contain averages from data in the preceding columns for Plots NE and NW.

(c) Bolded rows contain averages from data in the preceding columns for Plots SE and SW.

Deposition of silt, in a large enough quantity to change the pea gravel content (inflation), would also cause an increase in silt density. Because this situation is not supported by the data, the apparent decrease in silt density (the amount of silt per unit mass of soil) is most likely due to an increase in plant debris and soil organic matter. These data, in combination with the pea gravel contents, show the gravel admixture reduces erodibility, while allowing for successful establishment of vegetation. 


\subsection{Summary and Conclusions}

During the last year, testing and monitoring continued to measure and evaluate the influence of eolian stresses on the surface of a full-scale prototype barrier. After vegetation was established on the surface, the soil loss by wind erosion was eliminated; consequently, the study was redirected to focus on necessary wind measurements, so the physical traps and sensors were removed from the site.

WY-1997 test year was generally characterized by normal wind. The average wind speed at the 2-m elevation on the barrier was $27.6 \mathrm{~m} \mathrm{~s}^{-1}$, compared to a normal wind of $3.4 \mathrm{~m} \mathrm{~s}^{-1}$ for the Hanford Site and a mean of $22 \mathrm{~m} \mathrm{~s}^{-1}$ from a site at ground level and adjacent to the barrier. Wind velocities have been generally higher on the elevated surface, decreasing to the edge (Station 02) and becoming smallest at ground level (Station 03). The exposed, elevated, vegetated surface cover of the PSB is, therefore, subjected to greater erosive stresses than the surrounding natural environment. Wind stress parameters calculated from peak gusts were generally lower than the values from the literature and PNNL wind tunnel measurements, and have decreased over time. The lower value of friction velocity and its decrease with time is related to an increase in plant cover and plant height, both of which increase turbulent exchange over the barrier. Roughness heights were larger and the mean plant height calculated from roughness heights was identical to field-measured values.

The mean gravel content $(0-10 \mathrm{~cm})$ in WY-1997 was significantly smaller than the WY-1994 value. No differences were found between plots within treatments or between the two treatments in WY-1997. However, the irrigated treatment showed the greatest decline from WY-1994. This result is a reflection of the effect of organic matter and plant debris on the composition of the surface layer $(0-2 \mathrm{~cm}$ depth). Bulk samples $(2-10 \mathrm{~cm})$ have shown no significant differences in gravel content over the last three years. Surface gravel content decreased slightly and silt dry density showed no change. These results indicate a stable surface that has undergone little or no soil loss, and a surface that obviously benefitted from the presence of plants. This vegetation prevented wind from coming in direct contact with the soil, one of the prerequisites for wind erosion.

Two of the main issues raised in extrapolating the results of laboratory and wind tunnel tests on admixture composition to a field-scale barrier included 1) the practicality of deploying an admixture at the field scale, and 2) whether a uniform admixture composition could be maintained throughout the life of the barrier. The results of this task show that a $15 \%$ pea gravel admixture can be effectively deployed at the field scale and can successfully reduce the erodibility of vulnerable soils. Results also show that field-measured stress parameters can allow more accurate predictions of wind velocity profiles above vegetated barrier surfaces than can be obtained from literature and wind tunnel values. 


\subsection{Biointrusion}

Plants and animals influence water and wind erosion and the hydrologic characteristics of landfill covers, such as the prototype barrier (Link et al. 1995a,b). Restoration of the barrier surface was done in the late fall of 1994, as discussed in Gee et al. (1995). Conclusions from the first two years' observations suggest that plants dry out the surface under most conditions, even with added water and that plants virtually eliminate wind and water erosion (Gee et al. 1995, 1996). Fiscal year 1997 (FY-1997) studies on the biological component of the prototype barrier include extensive observations of plant and animal characteristics.

Vegetative characteristics were measured to assess plant community dynamics. Increasing biodiversity supports the proposition that increased complexity provides increased reliability of the surface to function with changing conditions. The best plant community for water extraction consists of a mixture of perennial species varying in rooting depth and in seasonal activity (phenology) patterns. Shrub survivorship and reproduction were documented to track the viability of these important plants on the surface. A sustainable surface is defined as one in which deep rooted shrubs survive and reproduce. The worst condition is dominance by a few alien annual species, such as Bromus tectorum (Cheatgrass) with shallow roots.

Measurement of vegetative cover patterns is required to support any evidence of spatial variation in soil water contents. The greater cover of deep-rooted shrubs, such as Artemisia tridentata (Big sagebrush), serves to keep the surface dry. Increasing cover of shallow rooted grasses can lead to increased soil water content. This year, an analysis of cover on the west facing 1:10 side slope is included. This side slope consists of gravel that encourages drainage in the periphery of the barrier upper surface. More vegetation on this side slope will reduce the risk of erosion. Root observations continued to further define the dynamics of root length density in both treatments. Additional roots increase the ability of plants to extract water from the surface. This year the study also provided information on the relative amount of dead roots in both treatments.

Plant height is measured to describe the effect of treatments on plant activity. For instance, short plants transpire less water than tall plants. This year the canopy leaf area of $A$. tridentata was investigated to provide leaf area index values that are useful in explaining ET rates from the surface. Gas exchange rates in both treatments were continued to document plant health and to provide data for computing transpiration rates from the surface through $A$. tridentata.

Animal evidence and burrows were assessed on the surface. Animal burrowing that disturbs the soil increases the incursion of alien annuals on the surface. Increased burrowing has negative consequences for the hydrology and erosion protection abilities of the surface.

\subsection{Vegetation}

Documented vegetation characteristics include floristics composition, ground cover and spatial distribution, plant height, canopy leaf area, gas exchange rate, roots, shrub survivorship, and reproduction. Data analyses for this study used JMP version 2.0.2 software (Sall et al. 1991). Mean data are presented with one standard error. 


\subsubsection{Floristics of the Restored Surface}

The floristics of engineered surfaces is dynamic (Link et al. 1994a) and can influence barrier performance at Hanford (Link et al. 1995b). To document the floristics composition of the barrier requires periodic observations of the occurrence of various species.

A species plant list was developed in WY-1995, WY-1996, and WY-1997. This list was compiled through several inspections each year. For identifications, Hitchcock and Cronquist (1973) was consulted. The species list is presented in Table 5.1 with documentation of the origination, occurrence, and life-form of each species on the barrier surface.

The surface was restored with seedlings of Artemisia tridentata (Big sagebrush) and Chrysothamnus nauseosus (Gray rabbitbrush), then seeded with a mixture of native perennial grasses. This mixture included Poa sandbergii (Sandberg's bluegrass), Agropyron dasystachyum (Thickspike wheatgrass), Oryzopsis hymenoides (Indian ricegrass), Poa ampla (Sherman's big bluegrass), Stipa comata (Needleand-thread grass), Pseudoroegneria spicata (Bluebunch wheatgrass), and Sitanion hystrix (Bottlebrush squirreltail).

A total of 38 species have been observed since WY-1995. Currently, 12 families are present of which Brassicaceae, Compositae, and Poaceae comprise $68 \%$ of the 38 species. As of WY-1997, 57\% of the species are native to the West and the rest are invasive aliens. Annuals comprise $46 \%$ of the species and $54 \%$ are biennials or perennials.

The new species observed in WY-1997 include Chrysothamnus viscidiflorus (Green rabbitbrush), Conyza canadensis (Horseweed), Lupinus pusillus (Low lupine), and an Astragalus (Milkvetch) species (Table 5.1). Seeds of new species likely are carried to the surface by wind, dust devils, animals, and humans. All of the species present in WY-1996 were found again in WY-1997.

The biodiversity of the surface has increased from WY-1995 through WY-1997. The number of annuals has varied from 12 to 16 , while the number of perennials has increased from 11 in WY-1995 to 19 in WY-1997 (Figure 5.1). The total number of species has increased from 24 to 35 in the same period. In WY-1995, $55 \%$ of the species were annuals. In contrast, only 44 and $46 \%$ of the species were annuals in WY-1996 and WY-1997, respectively. The continued increase in the number of perennials, compared with annuals, suggests the plant community will become increasingly dominated by perennials. A highly diverse mix of perennials is preferred because of its more efficient use of water.

The plant community can be thought of as functionally mature. It is an artificial construct, yet is functionally similar to that of nearby natural plant communities. Similar native plant communities extract essentially all the available water from the soil profile (Link et al. 1990, Link et al. 1994b), as does the community on the PSB. The capability of the plants to remove water from the surface will remain as long as a functionally complex community exists. The water extraction abilities of less complex plant community, such as those dominated by invasive alien species, can be less effective (Link et al. 1994a). The likelihood of the surface becoming dominated in the future by invasive aliens, and then failing, depends on propagule proximity and soil surface disturbance.

When soils at Hanford are disturbed, invasive species generally dominate, as long as an invasive seed source is close by. If soils are not grossly disturbed, the native community is likely to remain with its 
Table 5.1. Plant Species Observed on the Prototype Surface Barrier

\begin{tabular}{|c|c|c|c|c|}
\hline $\begin{array}{l}\text { Scientific Name } \\
\text { (Family Species) }\end{array}$ & Common Name & Notes $^{(\mathbf{n})}$ & $\begin{array}{l}\text { Presence }^{(\mathbf{b})} \\
(95,96,97)\end{array}$ & Lifeform \\
\hline$\frac{\text { Boraginaceae }}{\text { Amsinckia lycopsoides }}$ & Devil's lettuce & $\mathrm{n}$ & $1,1,1$ & ann. forb \\
\hline \multicolumn{5}{|l|}{ Brassicaceae } \\
\hline Cardaria draba & Whitetop & $\mathrm{i}$ & $0,1,1$ & per. forb \\
\hline Chorispora tenella & Blue mustard & $\mathrm{i}$ & $1,0,1$ & ann. forb \\
\hline Descurainia pinnata & Western transymustard & $\mathbf{n}$ & $1,1,1$ & ann. forb \\
\hline Draba verna & Spring whitlowgrass & $\mathbf{i}$ & $1,1,1$ & ann. forb \\
\hline Sisymbrium altissimum & Jim Hill tumblemustard & $\mathrm{i}$ & $1,1,1$ & ann. forb \\
\hline \multicolumn{5}{|l|}{ Chenopodiaceae } \\
\hline Chenopodium leptophyllum & Slimleaf goosefoot & $\mathbf{n}$ & $1,1,1$ & ann. forb \\
\hline Salsola kali & Russian thistle & i & $1,1,1$ & ann. forb \\
\hline \multicolumn{5}{|l|}{ Compositae } \\
\hline Achillaea millifolium & Yarrow & $\mathrm{n}$ & $1,0,1$ & per. forb \\
\hline Ambrosia acanthicarpa & Bur ragweed & $\mathrm{n}$ & $1,0,1$ & ann. forb \\
\hline Artemisia tridentata & Big sagebrush & $n, r$ & $1,1,1$ & per. shrub \\
\hline Chrysothamnus nauseosus & Gray rabbitbrush & $\mathbf{n}, \mathbf{r}$ & $1,1,1$ & per. shrub \\
\hline Chrysothamnus viscidiflorus & Green rabbitbrush & $\mathbf{n}$ & $0,0,1$ & per. shrub \\
\hline Conyza canadensis & Horseweed & $\mathrm{n}$ & $0,0,1$ & ann. forb \\
\hline Lactuca serriola & Prickly lettuce & i & $1,1,1$ & ann. forb \\
\hline Machaeranthera canescens & Hoary aster & $\mathrm{n}$ & $0,1,1$ & bi., per. forb \\
\hline Tragopogon dubius & Yellow salsify & $\mathrm{i}$ & $0,1,1$ & ann. forb \\
\hline \multicolumn{5}{|l|}{ Convolvulaceae } \\
\hline Convolvulus arvensis & Field bindweed & $\mathrm{i}$ & $0,1,1$ & per. forb \\
\hline \multicolumn{5}{|l|}{ Geraniaceae } \\
\hline Erodium cicutarium & Storksbill & $\mathrm{i}$ & $1,1,1$ & ann. forb \\
\hline
\end{tabular}




\begin{tabular}{|c|c|c|c|c|}
\hline $\begin{array}{l}\text { Scientific Name } \\
\text { (Family Species) }\end{array}$ & Common Name & Notes ${ }^{(2)}$ & $\begin{array}{l}\text { Presence }^{(\mathbf{b})} \\
(95,96,97)\end{array}$ & Lifeform \\
\hline \multicolumn{5}{|l|}{ Hydrophyllaceae } \\
\hline Phacelia linearis & Threadleaf scorpionweed & $\mathrm{n}$ & $1,0,0$ & ann. forb \\
\hline \multicolumn{5}{|l|}{ Leguminosae } \\
\hline Astragalus sp. & Milkvetch & $\mathrm{n}$ & $0,0,1$ & per. forb \\
\hline Lupinus pusillus & Low lupine & $\mathrm{n}$ & $0,0,1$ & ann. forb \\
\hline Melilotus alba & White sweetclover & $\mathrm{i}$ & $0,1,1$ & ann. forb \\
\hline \multicolumn{5}{|l|}{ Malvaceae } \\
\hline Sphaeralcea munroana & Munro's globemallow & $\mathrm{n}$ & $0,1,1$ & per. forb \\
\hline Onagraceae & 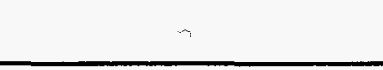 & & & \\
\hline Epilobium paniculatum & Tall willowherb & $\mathrm{n}$ & $0,1,1$ & ann. forb \\
\hline \multicolumn{5}{|l|}{ Poaceae } \\
\hline Agropyron cristatum & Creasted wheatgrass & $\mathrm{i}$ & $0,1,1$ & per. grass \\
\hline Agropyron dasytachyum & Thickspike wheatgrass & $\mathrm{n}, \mathbf{r}$ & $1,1,1$ & per. grass \\
\hline Agropyron intermedium & Intermediate wheatgrass & i & $0,1,1$ & per. grass \\
\hline Bromus tectorum & Cheatgrass & $\mathbf{i}$ & $1,1,1$ & ann. grass \\
\hline Oryzopsis hymenoides & Indian ricegrass & $\mathrm{n}, \mathrm{r}$ & $1,1,1$ & per. grass \\
\hline Poa ampla & Sherman's big bluegrass & $\mathbf{r}$ & $1,1,1$ & per. grass \\
\hline Poa bulbosa & Bulbous bluegrass & $\mathbf{i}$ & $1,1,1$ & per. grass \\
\hline Poa sandbergii & Sandberg's bluegrass & $\mathrm{n}, \mathbf{r}$ & $1,1,1$ & per. grass \\
\hline Pseudoroegneria spicata & Bluebunch wheatgrass & $\mathrm{n}, \mathrm{r}$ & $1,1,1$ & per. grass \\
\hline Sitanion hystrix & Bottlebrush squirreltail & $\mathrm{n}, \mathrm{r}$ & $1,0,0$ & per. grass \\
\hline Stipa comata & Needle-and thread grass & $\mathrm{n}, \mathrm{r}$ & $1,0,1$ & per. grass \\
\hline Triticum aestivum & Wheat & $\mathrm{i}$ & $1,0,0$ & ann. grass \\
\hline \multicolumn{5}{|l|}{ Verbenaceae } \\
\hline Verbena bracteata & Bracted verbena & $\mathrm{n}$ & $0,1,1$ & per. forb \\
\hline
\end{tabular}

(a) Native plant species (n), invasive alien species (I), and species used to restore the prototype barrier (r) noted in this column.

(b) Presence by year is indicated by $0=$ not present and $1=$ present; position in the column shows the corresponding year $($ left $=W Y-1995$, middle $=W Y-1996$, and right $=W Y-1997)$

(c) Abbreviations in this column: ann.=annual; per.=perennial; bi.=biennial. 


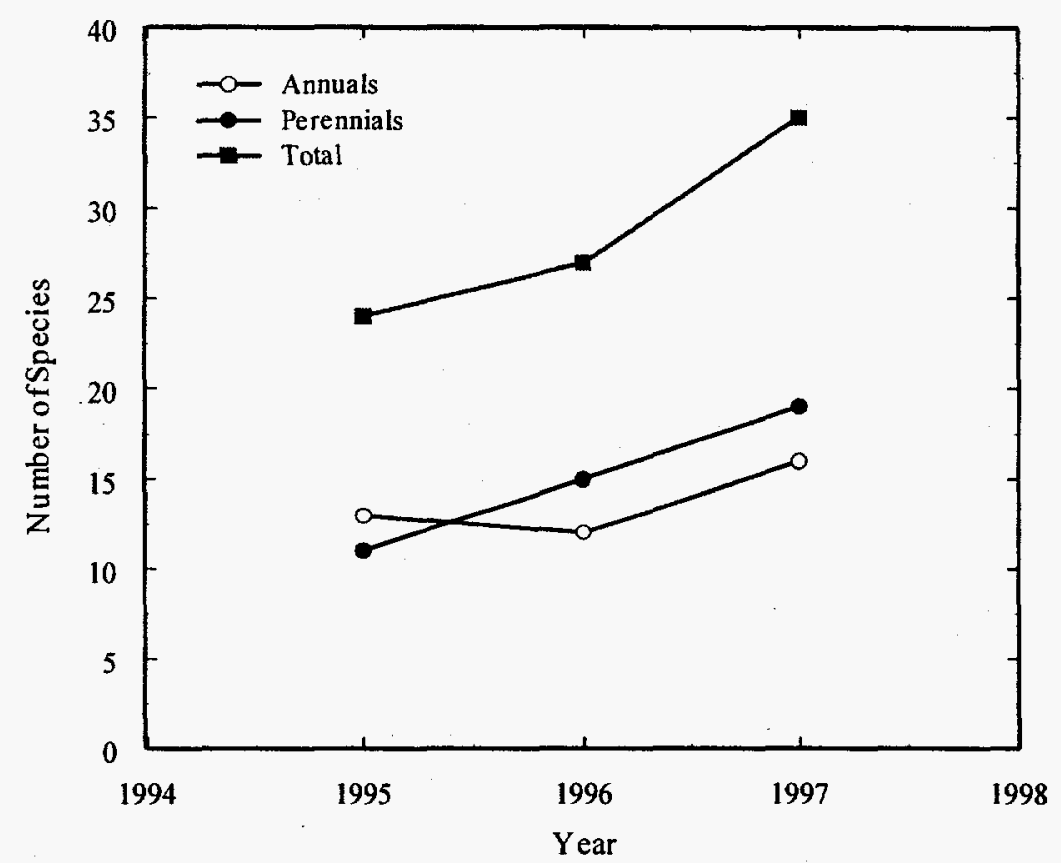

Figure 5.1. Number of Annual and Perennial Species Including Total Species on Barrier's Surface.

functionality intact, even with a component of invasive species present. This situation was true for studies at McGee Ranch (Link et al. 1994b). The worst case scenario is the concurrent presence of $B$. tectorum, soil disturbance, and a hot fire that kills most of the perennial vegetation. These conditions lead to increases in cover by $B$. tectorum. If the cover is dominated by $B$. tectorum, the ability to recycle water back to the atmosphere will be reduced, thus increasing the risk for drainage. The risk associated with dominance by invasive alien annual species on cover caps needs to be addressed.

\subsubsection{Cover Analyses and Spatial Distribution}

In WY-1997, cover and spatial distribution of surface conditions were examined on the west facing 1:10 side slope and on the upper surface.

\subsubsection{Side Slope Cover}

The west facing 1:10 side slope was examined to assess the development of vegetative cover. This side slope and the surface were hydroseeded in late 1994 at the same time. The same perennial grass seed mix that was applied to the surface was applied to the side slope. The primary difference between the side slope and the surface is soil texture. The side slope is gravel and the upper surface is a silt-pea gravel admixture as previously described. 
The side slope was assessed on June 18, 1997. Five line transects were placed equidistant on the surface, oriented up and down the slope. On each line transect, the cover was sampled at $10 \mathrm{~m}$ intervals from the toe to the top of the slope. Cover was assessed by placing a modified Daubenmire (1959) quadrat on the surface and estimating percent cover within it. The modified quadrat is a rectangle $20 \mathrm{~cm}$ by $50 \mathrm{~cm}$ in which the space is divided by strings into 10 areas, each $10 \mathrm{~cm}^{2}$. This smaller area is used to estimate cover with a resolution of $1 \%$. The observer visually estimates cover of each plant species within each subquadrat in $10 \%$ categories. If only one subquadrat contains a particular species in the $0-10 \%$ cover category, its cover within the entire $100 \mathrm{~cm}^{2}$ quadrat is $1 \%$. This procedure was used to estimate cover of each plant species, litter, and bare ground. Plant species were composited into perennial grass and annual or biennial cover classes.

Vegetative cover was greatest at the toe of the side slope, decreasing toward the top of the slope (Figure 5.2). Annual or biennial species had the largest cover, nearly $30 \%$ at the toe, but less than $10 \%$ elsewhere. Perennial grass cover was less than $10 \%$ at all locations with the greatest cover occurring at 10,20 , and $30 \mathrm{~m}$ from the toe. Litter cover was substantial (near $70 \%$ ), only at the toe, and less than $10 \%$ elsewhere. 'Bare ground cover was near $15 \%$ at the toe, gradually rising to more than $90 \%$ at the top. Combined vegetation and litter cover is the greatest at the toe, gradually decreasing toward the top. The combination cover was nearly $30 \%$ at 10 and $20 \mathrm{~m}$ from the toe.

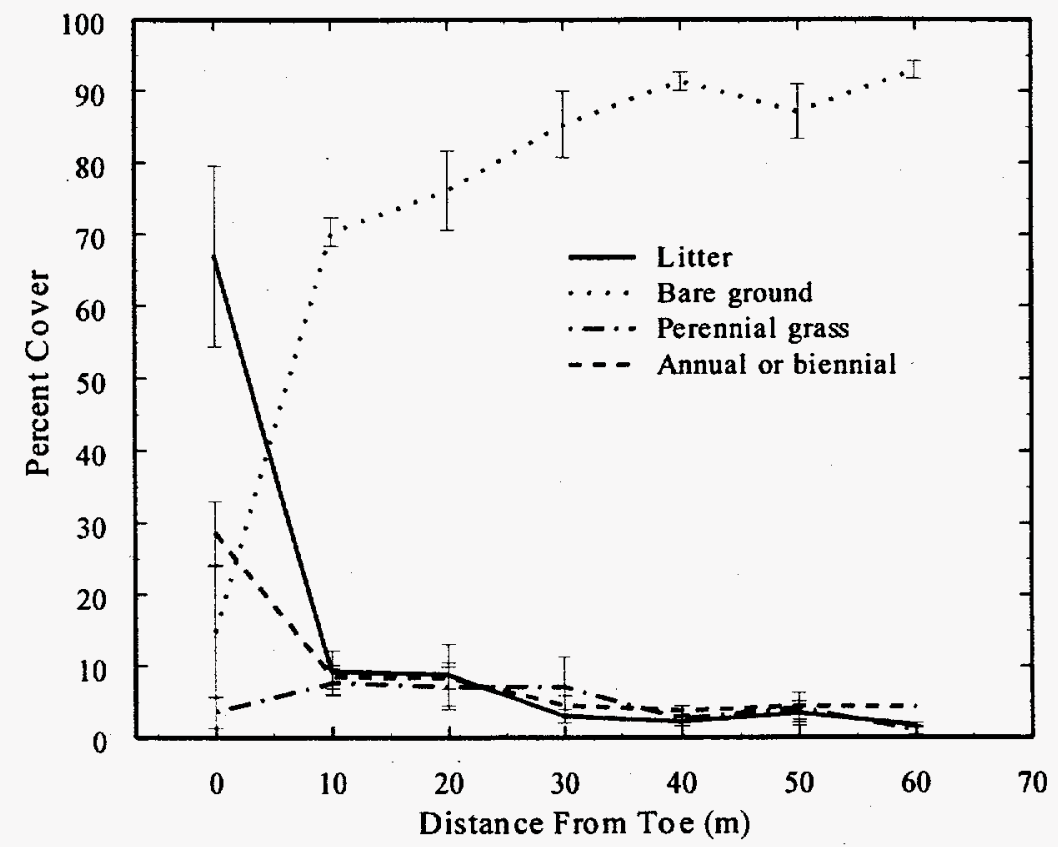

Figure 5.2. Percent Cover of Litter, Bare Ground, and Perennial Grasses Plus Annual or Biennial Plant Species on the West Facing Side Slope. (Error bars are one standard error of the mean based on five replicates.)

The greater cover of vegetation at the toe may be due to location, relative to surrounding seed sources. The annual or biennial species found near the toe were primarily Bromus tectorum and Salsola kali that are also found near the toe, but outside the assessment area. Note, the seeds of $B$. tectorum will 
only move up the slope in dust devils. The toe also may be more conducive to plant establishment because of greater litter cover. This litter contains seeds and will aid in establishment by protecting germinating seeds from desiccation (drying out). Very little litter cover was found further up the slope. We have also observed more vegetative cover in the areas on the gravel slope where silt had been inadvertently distributed during construction. These areas have only a very thin layer of silt that is enough to support vegetative establishment. This assertion has not been tested.

\subsubsection{Surface Cover}

In WY-1995, grasses were mapped and found to be highly variable in their space. The variation was thought attributable to the hydroseeding process (Gee et al. 1995).

In WY-1996 and WY-1997, cover estimates of grasses, shrubs, herbaceous forbs, litter, and bare soil were made on each 9-m $\mathrm{m}^{2}$ quadrat patterned after Daubenmire (1959). Cover was estimated by visual inspection of each quadrat. Cover was assigned values 1 through 6 for percentage cover ranges as follows

$$
\begin{aligned}
& 1=0-5 \% \\
& 2=5-25 \% \\
& 3=25-50 \% \\
& 4=50-75 \% \\
& 5=75-95 \% \\
& 6=95-100 \% .
\end{aligned}
$$

Cover data, as scored by the Daubenmire technique, are ordinal; thus, statistical analyses are based on nonparametric approaches (Siegel 1956). Measures of central tendency for these data are given as the median and the mode. The median is the cover class value where half the values are greater; the mode is the cover class with the greatest frequency. Arithmetic means and parametric statistics are invalid for ordinal data because the distance between classes is not equal (Siegal 1956). Note the distance between the midpoints of classes 1 and 2 is $12.5 \%$, and the difference between the midpoints of classes 2 and 3 is $22.5 \%$. Differences between treatments and years for cover data in this study were assessed using the Mann-Whitney $U$ test (Siegel 1956). This test ranks values upon which parametric statistics are valid. For ease of interpretation, mapping data were converted to the midpoint of the percentage cover ranges.

Significant effects of the irrigation treatment and changes between WY-1996 and WY-1997 were observed for the cover data (Tables 5.2 and 5.3). These effects are discussed by treatments within years and by years within treatments. Cover data obtained in 1996 revealed significant effects of irrigation (Tables 5.2 and 5.3). Grass cover in the irrigated half was significantly greater than in the non-irrigated treatment, as indicated by the larger median value. Shrub cover was not significantly different between treatments. Based on $Z$ scores (Table 5.3), herbaceous cover was significantly greater in the nonirrigated treatment, although median and mode values were not sufficiently sensitive to reveal the difference (Table 5.2). No significant difference was noted in litter cover. Percentage of bare ground was significantly greater by $Z$ scores in the non-irrigated treatment than in the irrigated treatment of the surface (Table 5.3).

Cover data obtained in 1997 again revealed some significant effects of irrigation (Tables 5.2 and 5.3). Grass cover in the irrigated half was significantly greater than in the non-irrigated treatment, as 
Table 5.2. Median and Mode of the Percent Cover Classes

\begin{tabular}{|c|c|c|c|c|}
\hline Cover class & Treatment & Water Year & Median & Mode \\
\hline \multirow[t]{4}{*}{ Grass } & Irrigated & 1996 & $25-50$ & $5-25$ \\
\hline & & 1997 & $50-75$ & $50-75$ \\
\hline & Non-irrigated & 1996 & $5-25$ & $5-25$ \\
\hline & & 1997 & $25-50$ & $25-50$ \\
\hline \multirow[t]{4}{*}{ Shrub } & Irrigated & 1996 & $0-5$ & $0-5$ \\
\hline & & 1997 & $25-50$ & $25-50$ \\
\hline & Non-irrigated & 1996 & $0-5$ & $0-5$ \\
\hline & & 1997 & $25-50$ & $25-50$ \\
\hline \multirow[t]{4}{*}{ Herbaceous } & Irrigated & 1996 & $0-5$ & $0-5$ \\
\hline & & 1997 & $0-5$ & $0-5$ \\
\hline & Non-irrigated & 1996 & $0-5$ & $0-5$ \\
\hline & & 1997 & $0-5$ & $0-5$ \\
\hline \multirow[t]{4}{*}{ Litter } & Irrigated & 1996 & $5-25$ & $5-25$ \\
\hline & & 1997 & $50-75$ & $50-75$ \\
\hline & Non-irrigated & 1996 & $5-25$ & $5-25$ \\
\hline & & 1997 & $25-50$ & $25-50$ \\
\hline \multirow[t]{4}{*}{ Bare } & Irrigated & 1996 & $5-25$ & $5-25$ \\
\hline & & 1997 & $5-25$ & $25-50$ \\
\hline & Non-irrigated & 1996 & $5-25$ & $5-25$ \\
\hline & & 1997 & $25-50$ & $25-50$ \\
\hline
\end{tabular}

indicated by the larger median value. Shrub cover was significantly greater based on $Z$ scores in the nonirrigated half compared with the irrigated half. Shrubs on the irrigated half appear less vigorous than their counterparts on the non-irrigated half. This unexpected result is likely caused by competition with the more vigorous grasses on the irrigated half. Herbaceous cover showed no significant difference between the two plots. Litter cover was significantly greater in the irrigated half than in the non-irrigated half as indicated by the positive $Z$ score and larger median and mode values (Tables 5.2 and 5.3). The percentage of bare ground was significantly greater in the non-irrigated half than on the irrigated half of the surface (Table 5.3).

From WY-1996 to WY-1997, significant changes in nearly all surface cover classes occurred in both 
Table 5.3. Mann-Whitney UTest Results for Cover Class Comparisons Between Years Within Treatments and Between Treatments Within Year. (The $Z$ score, based on ranks, and the probability values are presented. The sign of the $Z$ score represents the direction of change between comparisons. Refer to Table 5.2.)

\begin{tabular}{|c|c|c|c|}
\hline \multicolumn{4}{|c|}{ Water Year (1996-1997) } \\
\hline Cover Class & Treatment & $Z$ score & Probability Level \\
\hline \multirow[t]{2}{*}{ Grass } & Irrigated & 10.26 & $<0.00001$ \\
\hline & Non-irrigated & 12.58 & $<0.00001$ \\
\hline \multirow[t]{2}{*}{ Shrub } & Irrigated & 14.63 & $<0.00001$ \\
\hline & Non-irrigated & 14.55 & $<0.00001$ \\
\hline \multirow[t]{2}{*}{ Herbaceous } & Irrigated & -6.05 & $<0.00001$ \\
\hline & Non-irrigated & -8.94 & $<0.00001$ \\
\hline \multirow[t]{2}{*}{ Litter } & Irrigated & 14.07 & $<0.00001$ \\
\hline & Non-irrigated & 11.03 & $<0.00001$ \\
\hline \multirow[t]{2}{*}{ Bare } & Irrigated & -0.17 & 0.8674 \\
\hline & Non-irrigated & 2.18 & 0.0294 \\
\hline \multicolumn{4}{|c|}{ Treatment (Irrigated - Non-irrigated) } \\
\hline Cover class & Water Year & $Z$ score & Probability Level \\
\hline \multirow[t]{2}{*}{ Grass } & 1996 & 9.04 & $<0.00001$ \\
\hline & 1997 & 10.72 & $<0.00001$ \\
\hline \multirow[t]{2}{*}{ Shrub } & 1996 & -0.80 & 0.4252 \\
\hline & 1997 & -3.19 & 0.0014 \\
\hline \multirow[t]{2}{*}{ Herbaceous } & 1996 & -3.61 & 0.0003 \\
\hline & 1997 & 0.99 & 0.3207 \\
\hline \multirow[t]{2}{*}{ Litter } & 1996 & 0.47 & 0.6384 \\
\hline & 1997 & 11.53 & $<0.00001$ \\
\hline \multirow[t]{2}{*}{ Bare } & 1996 & -2.78 & 0.0055 \\
\hline & 1997 & -5.34 & $<0.0001$ \\
\hline
\end{tabular}


treatments (Tables 5.2 and 5.3). On the irrigated half of the surface, grass, shrub, and litter cover increased significantly, as indicated by $Z$ scores and by greater median and mode values. Based on the $Z$ score, herbaceous cover decreased significantly. On the non-irrigated treatment, all cover classes increased, except herbaceous, which decreased (Tables 5.2 and 5.3).

Mapping data are presented only for WY-1997. Maps for WY-1996 are found in Gee et al. (1996). Maps for percentage grass cover reveal greater cover in the irrigated treatment than in the non-irrigated treatment, with the greatest cover in the northeast corner of the surface (Figure 5.3). Mapping data for shrub cover reveals no particular pattern, other than the low values found in the northeast corner of the surface (Figure 5.4). The shrub cover in this corner likely is low because of the intense competition from the grasses in the area. Mapping data for herbaceous forbs reveals very little cover on the entire surface (Figure 5.5). This reduction is significant, relative to the mapping distribution in WY-1996 (Gee et al. 1996). Although a large number (22) of herbaceous species are present on the surface (Table 5.1), they are not common or concentrated anywhere. A higher cover of litter was present in the northeastern corner of the surface than elsewhere (Figure 5.6), most likely because of the high cover of grasses in that corner. In comparison with grass and litter cover, bare soil cover was the least prevalent in the northeastern corner (Figure 5.7).

\subsubsection{Plant Size}

The size of plants in water-limited ecosystems is positively correlated with available water (Link et al. 1990). Measurements of shoot height were taken to see if plants were taller in the irrigated treatment compared with the non-irrigated treatment. Data for all three years are presented to document change in $A$. tridentata and $C$. nauseosus. In WY-1997, canopy shape for $A$. tridentata was measured to relate the treatment to morphological characteristics and to estimate canopy leaf area and leaf area index.

\subsubsection{Plant Height}

Plant height for A. tridentata and C. nauseosus was measured with a meter stick in the irrigated and non-irrigated portions of the barrier in all three years. Observations were made on the height of $S$. kali (Russian thistle) and $A$. dasystachyum in each treatment and the results are presented in Gee et al. (1996). Differences between treatments for height data over the 3-year period were assessed by comparing regression relationships in time using a linear test approach (Neter and Wasserman 1974).

Chrysothamnus nauseosus grew significantly taller over the three years and were taller in the irrigated treatment than in the non-irrigated treatment (Figure 5.8). Plants in the irrigated treatment increased from 37.8 to $54.1 \mathrm{~cm}$ and those in the non-irrigated treatment increased from 31.4 to $42.9 \mathrm{~cm}$ from WY-1995 to WY-1997 (Figure 5.8). Linear regressions were significantly different for the two treatments $\left(F^{*}=7.43>F[0.95 ; 2,61]=3.15\right)$; see the linear test approach in Neter and Wasserman (1974). Although no height differences appeared between the treatments in any one year, when all data were combined, plants in the irrigated treatment were significantly taller than those in the non-irrigated treatment (Figure 5.8).

Artemisia tridentata grew significantly taller over the three years, but was not affected by irrigation (Figure 5.9). Plants in the irrigated treatment increased from 45 to $59.3 \mathrm{~cm}$, and those in the non- 


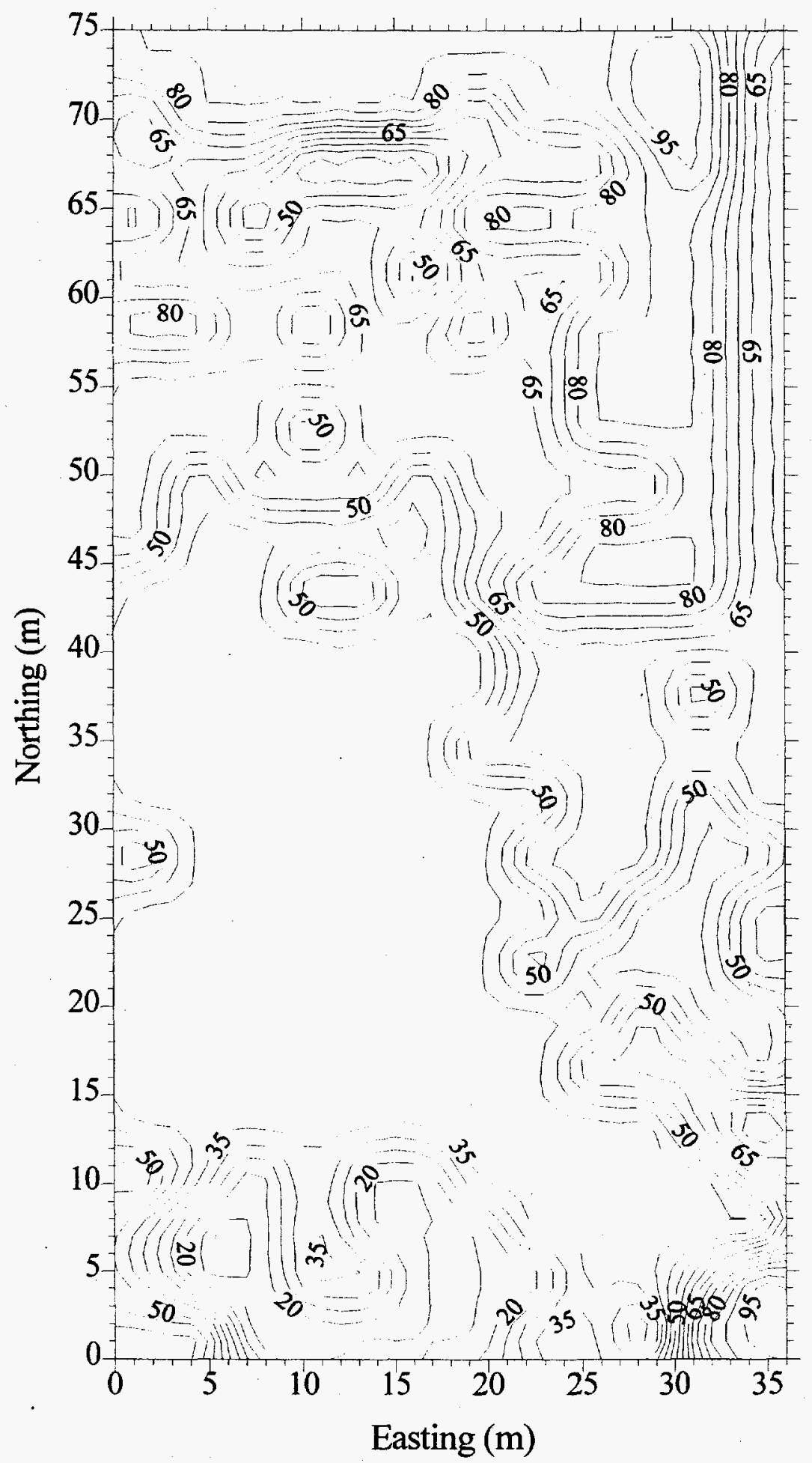

Figure 5.3. Percent Cover of Grasses on the Surface.

(Contour Interval $=5 \%$.) 


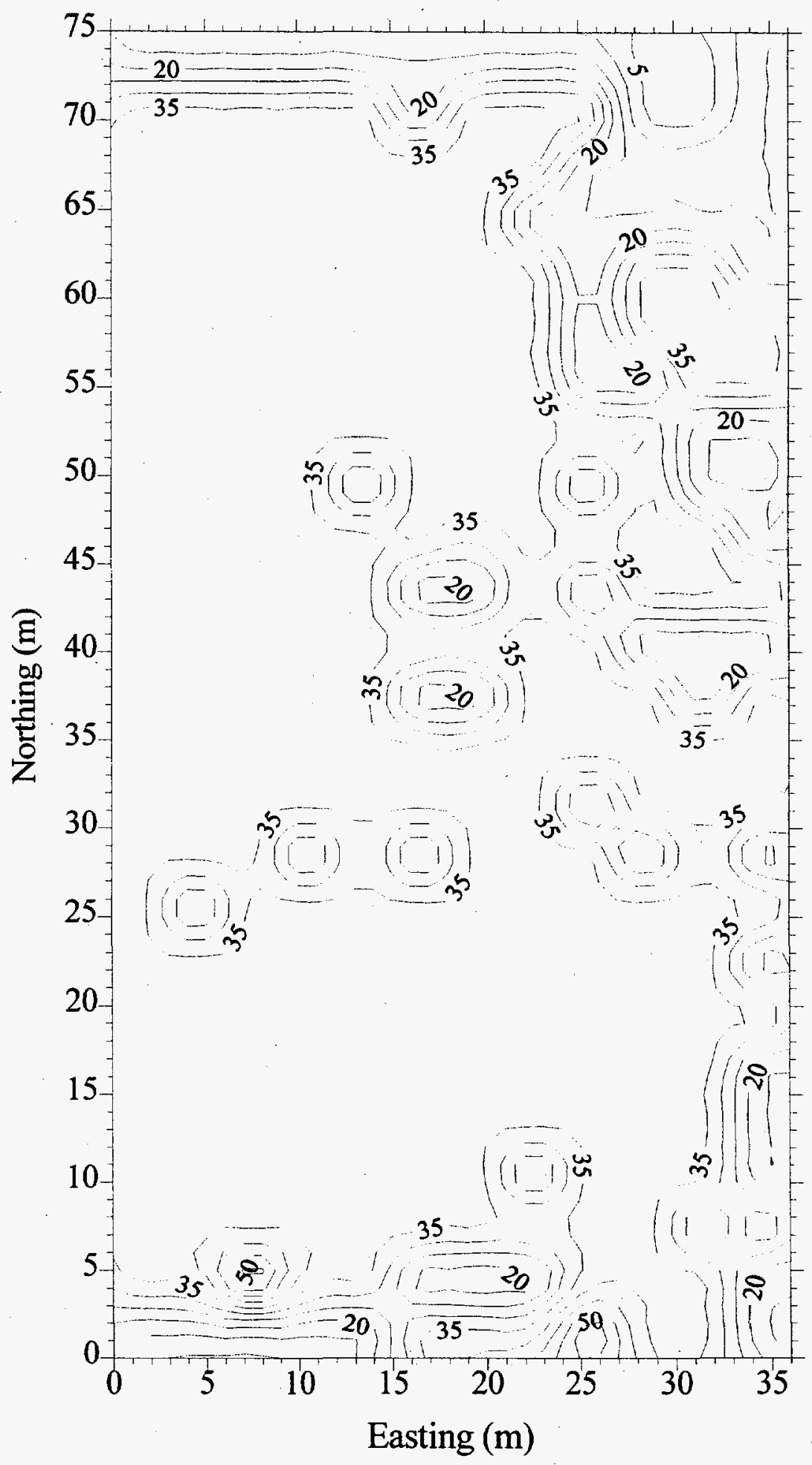

Figure 5.4. Percent Cover of Shrubs on the Surface. (Contour Interval $=5 \%$.) 


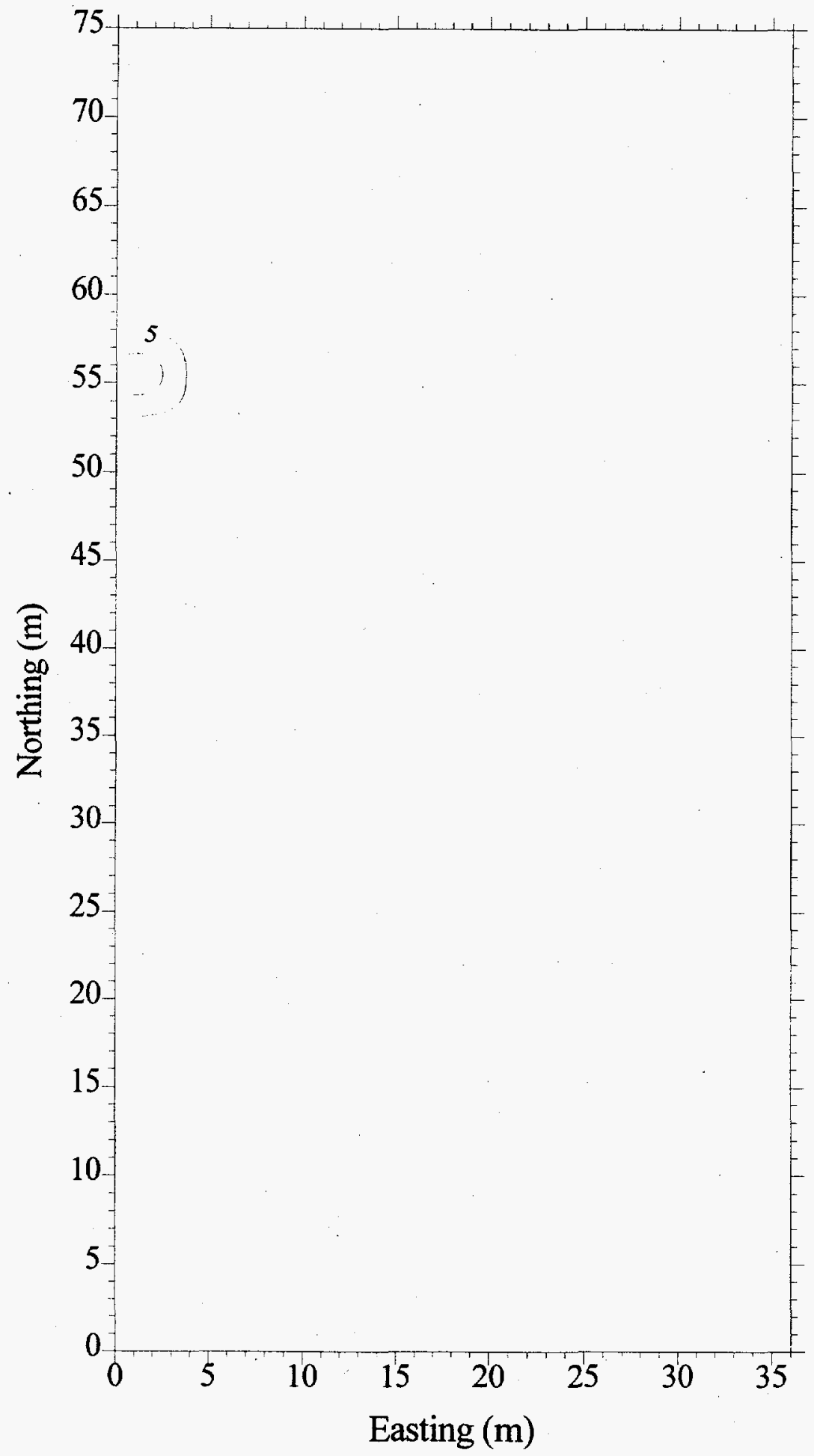

Figure 5.5. Percent Cover of Herbaceous Forbs on the Surface. (Contour Interval $=5 \%$.) 


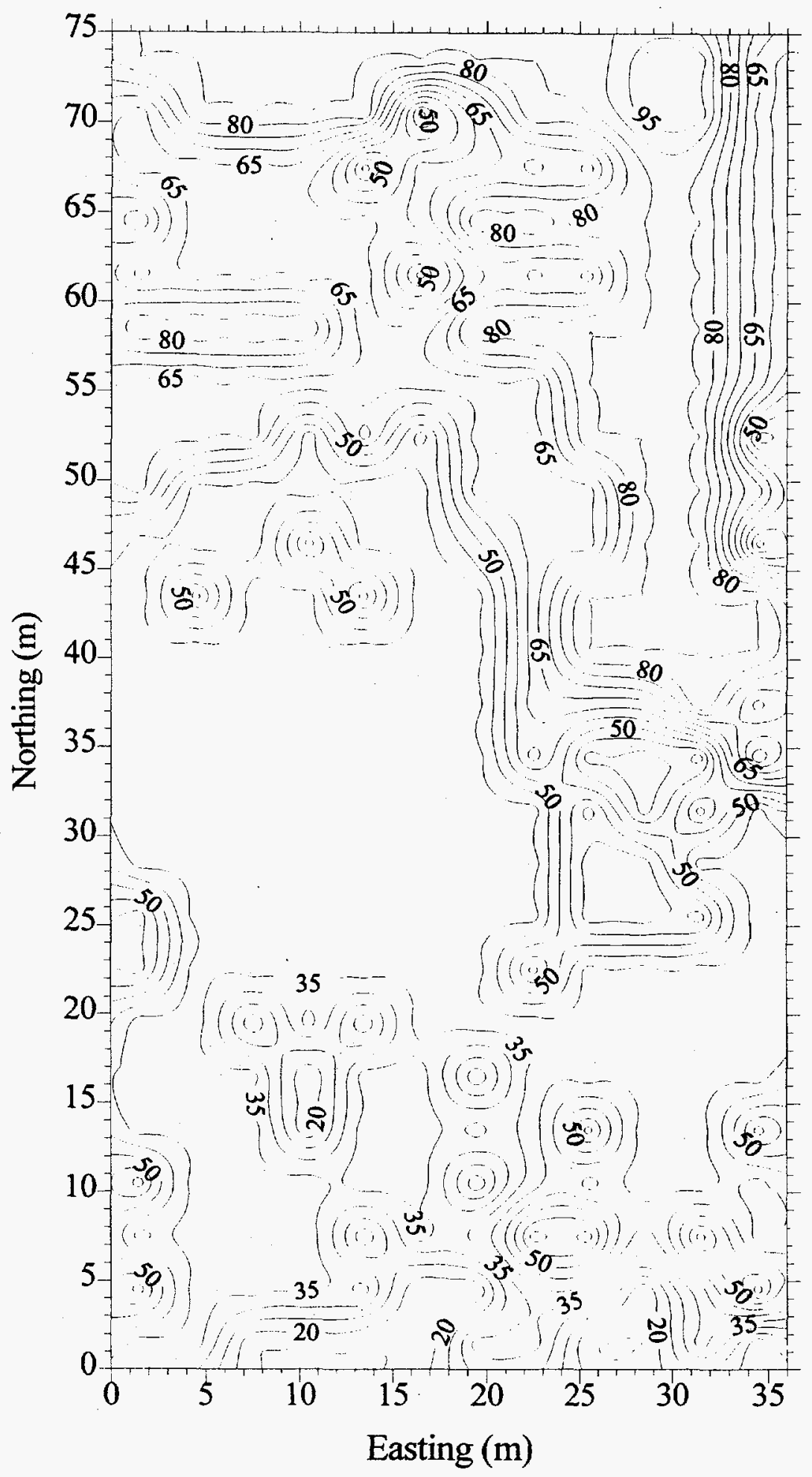

Figure 5.6. Percent Cover of Litter on the Surface. (Contour Interval $=5 \%$.) 


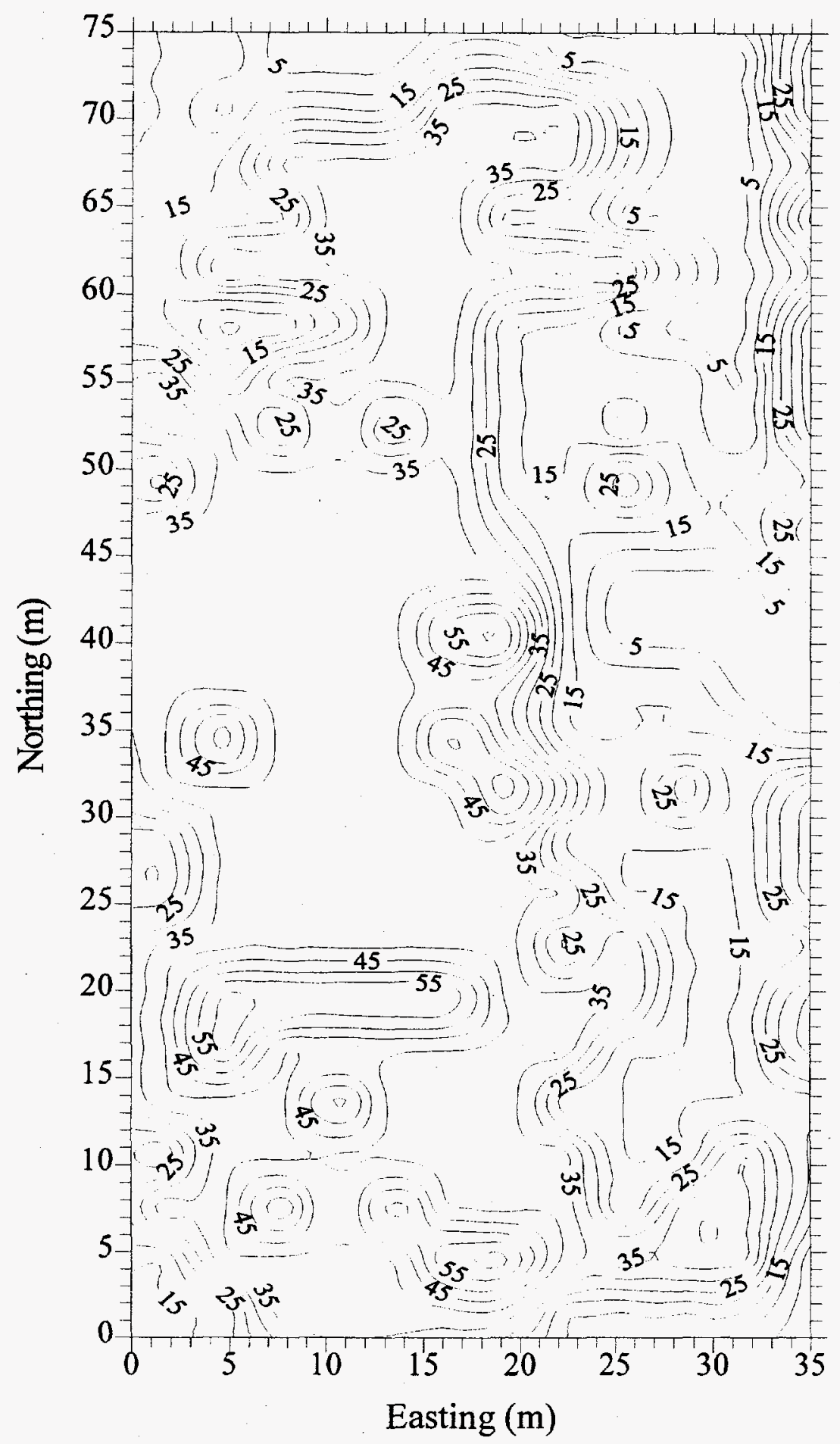

Figure 5.7. Percent Cover of Bare Soil on the Surface.

(Contour Interval $=5 \%$.) 


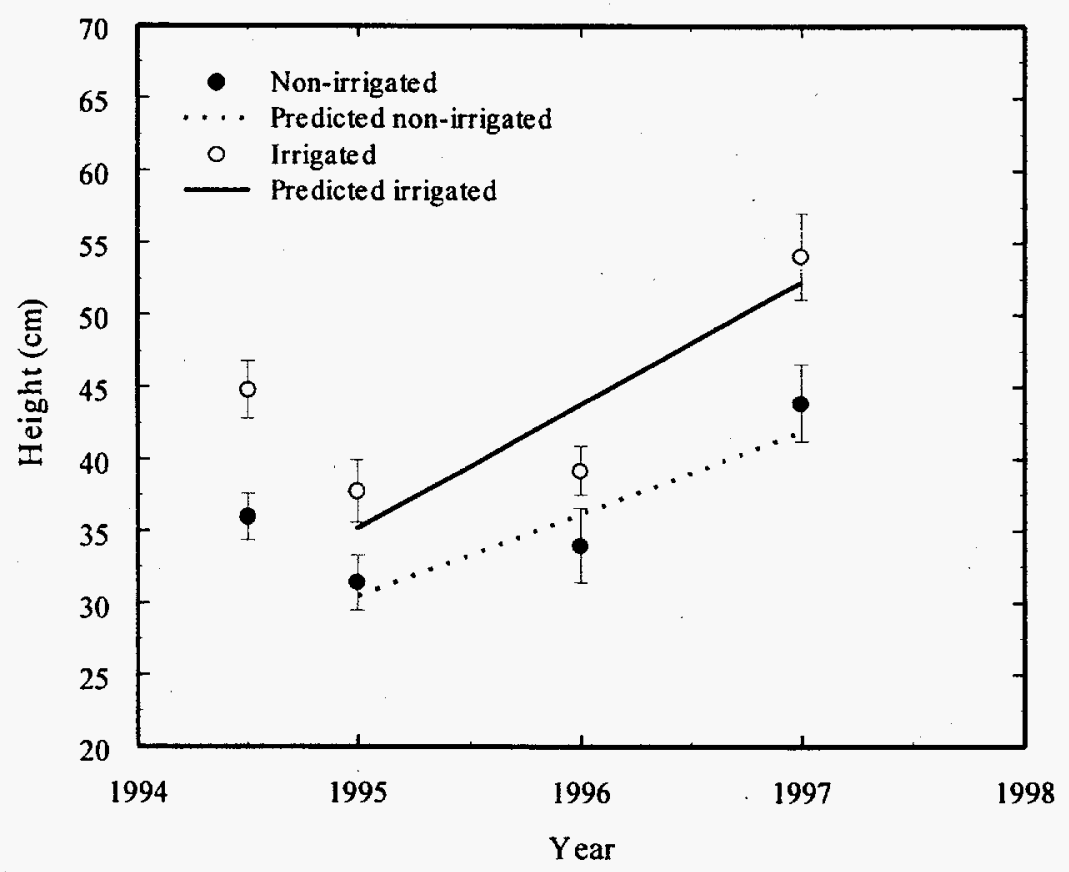

Figure 5.8. Height of Chrysothamnus nauseosus from WY-1995 to WY1997 in Irrigated and Non-irrigated Treatments. (The two means displayed outside the fitted data sets are the combined means over time for each treatment. These two means are significantly different. Error bars are one standard error of the mean.)

irrigated treatment increased from 37.1 to $64.7 \mathrm{~cm}$ from WY-1995 to WY-1997 (Figure 5.9). Linear regressions were not significantly different for the two treatments $\left(F^{*}=3.03<F^{*}[0.95 ; 2,101]\right)=3.10$; see Neter and Wasserman (1974). Thus, the data were combined to produce the linear regression line in Figure 5.10. No differences between the treatments were observed in any one year or when all data were combined. The data for the irrigated treatment suggests that, if irrigation were continued in the future, $A$. tridentata in the non-irrigated treatment may become significantly taller than those in the irrigated treatment.

\subsubsection{Artemisia tridentata Canopy Characteristics and Leaf Area}

In WY-1997, the canopy characteristics, leaf area, and leaf area index were investigated for $A$. tridentata. This investigation supported efforts to understand the hydrology of the surface with respect to the two treatments. To compute ET rates, it is necessary to compute plant transpiration rates. The transpiration rates for $A$. tridentata were estimated because it is the dominant shrub on the surface; it also will likely account for a large portion of plant transpiration from the surface. To compute transpiration rates for the entire shrub requires a measure of its entire leaf area. Canopy morphological measures were 


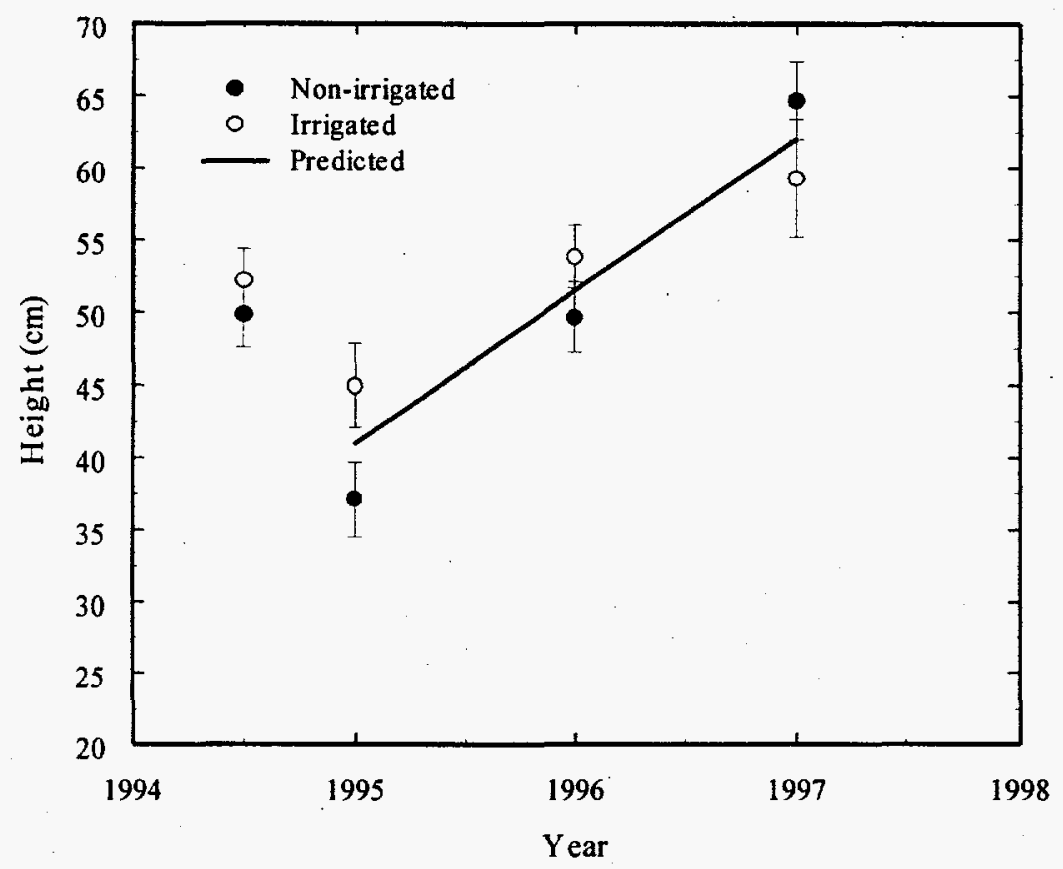

Figure 5.9. Height of Artemisia tridentata from WY-1995 to WY-1997 in Irrigated and Non-irrigated Treatments. (The two means displayed outside the fitted data set are the combined means over time for each treatment. These two means are significantly different. Error bars are one standard error of the mean.)

used to estimate canopy leaf area and leaf area index. Knowing the canopy leaf area and transpiration rates permits an estimate of canopy transpiration rates, as discussed in Section 5.1.4.

Observations were taken on April 15, May 15, and June 15 in 1997 to describe canopy characteristics, leaf area, and leaf area index dynamics. Canopy characteristics were measured to estimate leaf area, as described in Link et al. (1990). Canopy characteristics of the same individual shrubs were measured on the three dates. Shrubs were randomly chosen ( 20 from the non-irrigated treatment and 20 from the irrigated treatment), then labeled with metal tags numbered 1 through 40 .

The leaf area of $A$. tridentata was measured by double sampling, using a model relating leaf area to canopy measures. This model was developed by measuring the height, the greatest projected canopy diameter, and the diameter perpendicular to the greatest diameter, then relating these measures to harvested leaf area. These measurements were taken on five shrubs in April and seven shrubs in May and June in both treatment areas. Plants were chosen to encompass all possible shrub sizes found in both treatments. The shrubs were measured and then harvested to determine leaf area.

Harvested shrubs were placed in plastic bags and taken to a laboratory for measurement of mass and leaf area. Because the shrubs were large, each one was broken into similar pieces for sampling. The entire shrub was weighed and about $10 \%$ taken to measure leaf area. The mass of the sample piece was 


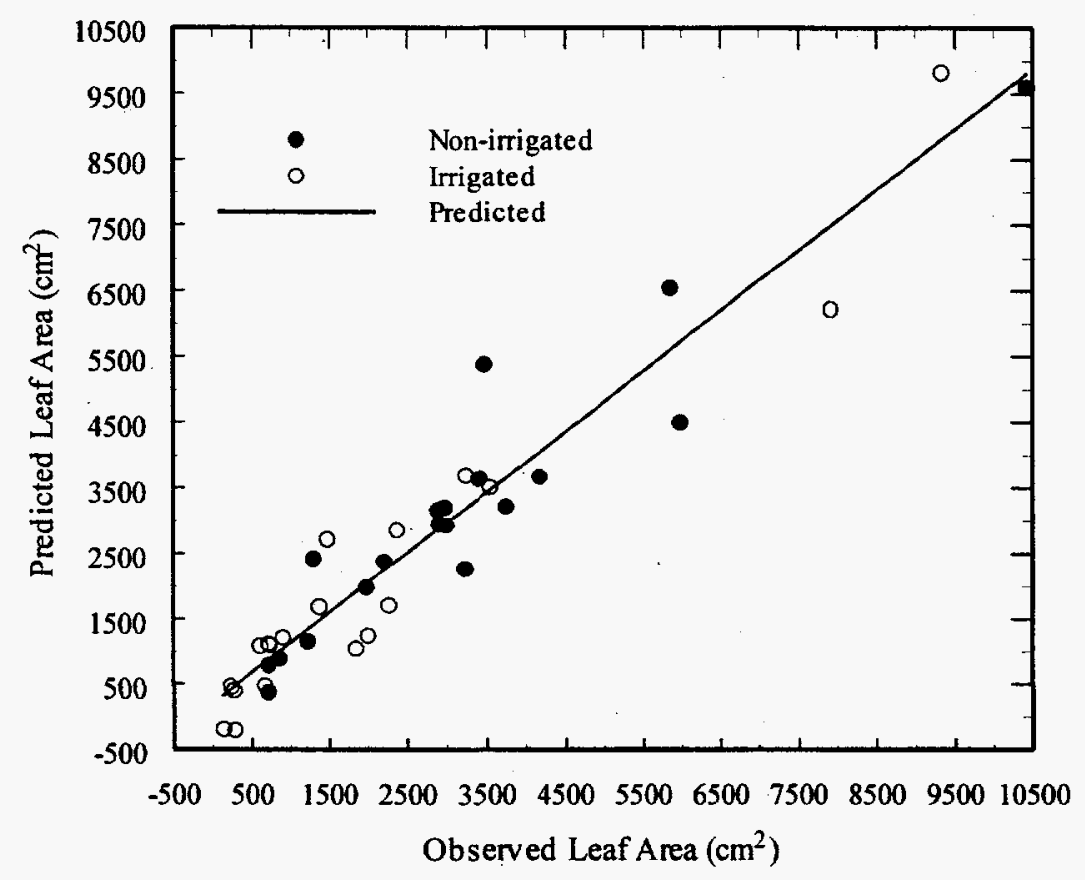

Figure 5.10. Predicted Leaf Area Using Equation 5.2 Correlated with Observed Leaf Area for Artemisia tridentata.

recorded. Leaves were then stripped from stems and single-sided green leaf area was determined with a Licor 3100 Leaf Area Meter (Licor, Inc., Lincoln, NE). The leaf area of the entire shrub was determined as

$$
L A_{\text {shrub }}=\text { Mass }_{\text {shrub }} \cdot L A_{\text {sample }} / \text { Mass } s_{\text {sample }}
$$

where $\mathrm{LA}_{\text {shrub }}$ is the total leaf area of the shrub $\left(\mathrm{cm}^{2}\right)$.

The model for leaf area is:

$$
Y=b_{0}+b_{1} \cdot d+b_{2} \cdot h+b_{3} \cdot w+b_{4} \cdot p w+b_{5} \cdot t r t+b_{6} \cdot h^{2}+b_{7} \cdot w^{2}+b_{8} h \cdot w \cdot p w+b_{9} \cdot w \cdot t r t
$$

where

$$
\begin{aligned}
& \mathrm{Y}=\text { leaf area }\left(\mathrm{cm}^{2}\right) \\
& \mathrm{d}=\text { day of the year }(1-365) \\
& \mathrm{h}=\text { plant height }(\mathrm{cm}) \\
& \mathrm{w}=\text { greatest projected canopy diameter }(\mathrm{cm}) \\
& \mathrm{pw}=\text { diameter } 90^{\circ} \text { to } \mathrm{w}(\mathrm{cm}) \\
& \mathrm{trt}=\text { treatment code }(1=\text { irrigated, } 0=\text { non-irrigated })
\end{aligned}
$$


The coefficients of the polynomial defined in Eq. (5.2) are as follows:

$$
\begin{array}{ll}
b_{0}=-1959 & b_{5}=1100 \\
b_{1}=-11.96 & b_{6}=-0.822 \\
b_{2}=56.52 & b_{7}=-3.287 \\
b_{3}=225.3 & b_{8}=0.0579 \\
b_{4}=-51.65 & b_{9}=-50.88
\end{array}
$$

This model (Eq. 5.2) was used to compute the leaf area of the 40 tagged shrubs.

The 38 plants divided between the treatments were used to create the model described in equation (5.2). The regression resulted in a significant $\left(F=35.5 ; p<0.00001 ; r^{2}=0.92\right)$ relation between observed and predicted values of leaf area (Figure 5.10). The correlation between predicted and observed data resulted in a slope of $0.92 \pm 0.045$ ( \pm 1 standard error) that is not significantly different from one; an intercept of $214 \pm 163$ is not significantly different from zero. Therefore, the use of equation (5.2) to predict leaf area of $A$. tridentata is justified.

Leaf area of $A$. tridentata was predicted, based on the day when plants were harvested, to create the model that also was within a few days of the time when the 40 individual shrubs in the two treatments were measured morphologically. The results of model predictions are presented in Figure 5.11 for both treatments over time in WY-1997. Of the 40 individual shrubs, four were smaller than the smallest individual used to create the model, which predicted negative values for these four; thus they were eliminated from further analysis. In the non-irrigated treatment, mean predicted canopy leaf area ranges from 3015 to $4831 \mathrm{~cm}^{2}$ from mid-April to mid-June. However, values ranged only from 1524 to 2329 $\mathrm{cm}^{2}$ in the irrigated treatment (Figure 5.11). Linear regressions were significantly different for the two treatments $\left(F^{*}=12.63>F(0.95 ; 2,106)=3.10\right)$. The only significant difference between mean predicted canopy leaf area in the non-irrigated and irrigated treatments occurred in April.

Canopy leaf area measurements were expressed as leaf area indexes $\left(\mathrm{m}^{2}\right.$ green leaf area $/ \mathrm{m}^{2}$ ground area). For this purpose, the mean predicted canopy leaf area was multiplied by the number of $A$. tridentata individuals in each treatment (Non-irrigated - 1977, Irrigated - 1686), divided by 10,000 to convert $\mathrm{cm}^{2}$ to $\mathrm{m}^{2}$, and then divided by $1296 \mathrm{~m}^{2}$ (the area in each half of the surface without the middle row [13]). Leaf area index (LAI) increased over time and was larger in the non-irrigated treatment than in the irrigated treatment (Table 5.4). Values ranged from 0.198 to 0.303 in the irrigated treatment and from 0.460 to 0.737 in the non-irrigated treatment. These estimated LAI values are comparable to those observed for A. tridentata on the Fitzner-Eberhardt Arid Lands Ecology Reserve (Link et al. 1990). Leaf area index values in Link et al. (1990) averaged 0.25 in a mature ecosystem dominated by $A$. tridentata. The values computed in the non-irrigated treatment are three times larger in June than observed in Link et al. (1990). It is likely that over time the $A$. tridentata element of the plant community will come into a steady state condition, if there are no fires, with an LAI closer to 0.25 . The density of individuals on the prototype surface is probably greater than in comparable natural communities. Such a comparison has not been made. 


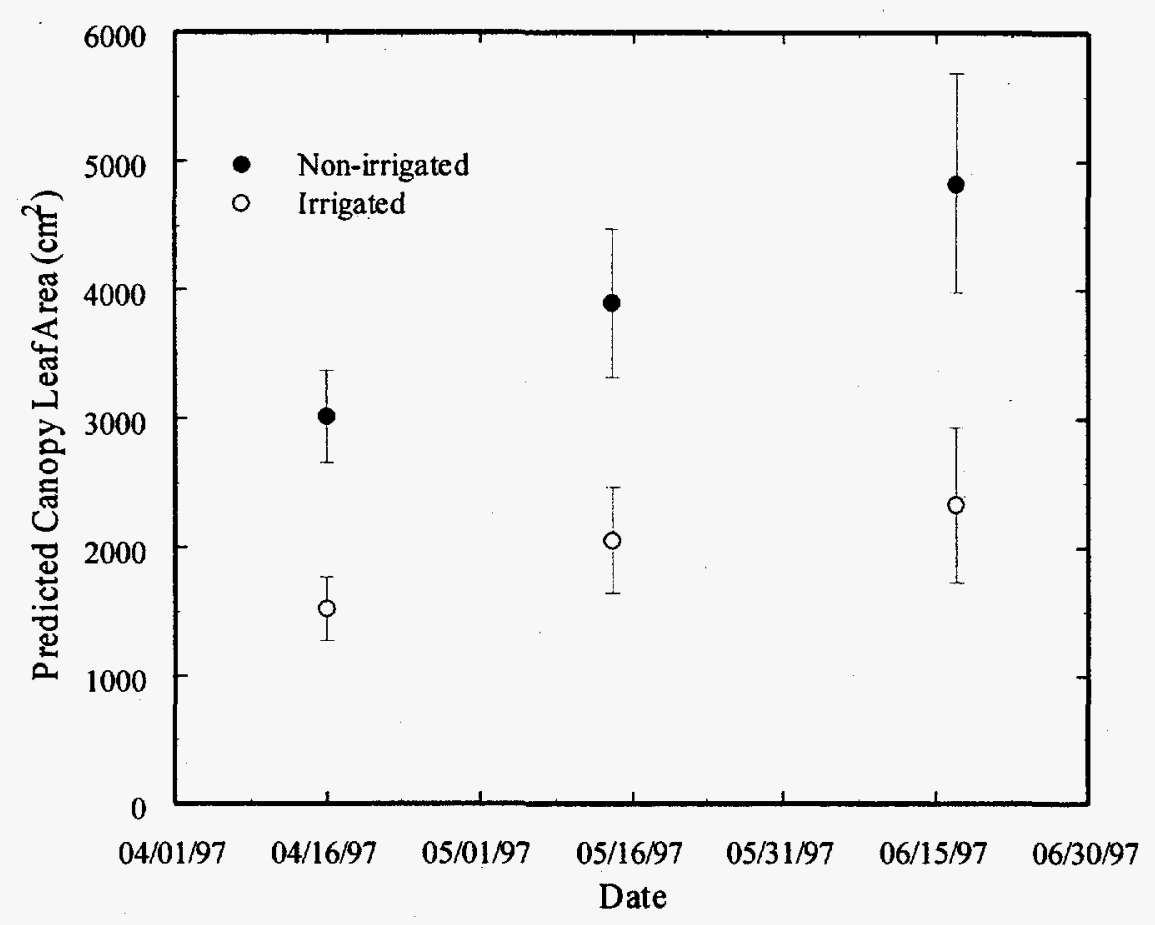

Figure 5.11. Predicted Mean Canopy Leaf Area of Artemisia tridentata for the Irrigated and Non-irrigated Treatments over 3 Months in WY-1997. (Error bars are one standard of the mean.)

\subsubsection{Gas Exchange}

Plant gas exchange data were collected on June 18, 1996 to continue observations made in WY-1995 and WY-1996. Transpiration and net photosynthetic data are presented. Such data are useful as an indication of the ability of shrubs to remove water from the surface. Comparisons are made for the effect of the irrigation treatment on gas exchange rates for $A$. tridentata. Previous gas exchange data collected for C. nauseosus indicate similar rates as for $A$. tridentata (Gee et al. 1996). Because of the similarity and the decreasing importance of $C$. nauseosus on the surface, only data for $A$. tridentata are presented in this report. These data are graphically presented with earlier data, as in Gee et al. (1996), to interpret long-term trends in plant gas exchange.

Gas exchange data were gathered with a Li-Cor 6200 gas exchange system. Such data are collected by placing a chamber over plant stem tips and allowing water vapor and $\mathrm{CO}_{2}$ to change over a few minutes. In WY-1997, a 10-cm length of stem was placed in the chamber for plants in the non-irrigated treatment and a shorter piece (less than $5 \mathrm{~cm}$ long) was used in the irrigated treatment. The varying amounts of exposed leaf area were used to maintain similar vapor pressures for the two treatment samples in the chamber. After observations were made, the stem was cut and a single-sided leaf area measured, using a Li-Cor 3100 Leaf Area Meter. All gas exchange observations were taken at midday and in full sun. 
Table 5.4. Estimated Leaf Area Index of Artemisia tridentata in Each Treatment in WY-1997.

\begin{tabular}{|l|c|c|}
\hline \multicolumn{1}{|c|}{ Treatment } & Date & Leaf area index \\
\hline Irrigated & April 16 & 0.198 \\
& May 14 & 0.268 \\
& June 17 & 0.303 \\
\hline \multirow{2}{*}{ Non-irrigated } & April 16 & 0.460 \\
& May 14 & 0.595 \\
& June 17 & 0.737 \\
\hline
\end{tabular}

In the non-irrigated treatment, transpiration rates increased from near $0.75 \mathrm{mmol} \mathrm{m}^{-2} \mathrm{~s}^{-1}$ in February to $19.7 \mathrm{mmol} \mathrm{m}^{-2} \mathrm{~s}^{-1}$ in late July. In the irrigated treatment, values were at a maximum of $14.2 \mathrm{mmol} \mathrm{m}^{-2} \mathrm{~s}^{-1}$ in June, dropping to $8.8 \mathrm{mmol} \mathrm{m}^{-2} \mathrm{~s}^{-1}$ in August (Figure 5.12). The only difference between treatments on any of the five days $(p>0.05)$ was in July, when the transpiration rate in the non-irrigated treatment was significantly greater than in the irrigated treatment $(p=0.033)$. The higher rate of transpiration in the non-irrigated treatment than in the irrigation treatment suggests that $A$. tridentata is under a hydration stress apparently caused by too much water. As discussed in Gee et al. (1996), plants in the irrigated treatment had much higher pre-dawn xylem pressure potential values than those in the non-irrigated treatment, an indication of no apparent water stress. Yet, a restriction is apparent in the ability of water to move through $A$. tridentata when it is supplied with three times normal precipitation. Perhaps excess water reduces the hydraulic conductivity of $A$. tridentata, leading to a reduction in transpiration rates.

Combining these transpiration data with leaf area data for the surface provides an estimate of the water loss rate from the surface through $A$. tridentata. This estimate assumes that transpiration rates of the entire shrub are similar to that of the stem tips used to collect the transpiration data. Estimates were computed by converting transpiration rates for June $18,1997\left(14.2 \mathrm{mmol} \mathrm{m}^{-2} \mathrm{~s}^{-1}\right.$ - irrigated, $9.7 \mathrm{mmol}$ $\mathrm{m}^{-2} \mathrm{~s}^{-1}$ - non-irrigated) to the equivalent that would leave the surface for the entire leaf area $\left(393 \mathrm{~m}^{2}\right.$ irrigated, $955 \mathrm{~m}^{2}$ - non-irrigated) on the surface in one hour $\left(20090 \mathrm{~mol} \mathrm{~h}^{-1}\right.$ - irrigated, $33352 \mathrm{~mol} \mathrm{~h}^{-1}$ non-irrigated). This figure was then converted to the equivalent depth of water on the surface $(0.46 \mathrm{~mm}$ $\mathrm{h}^{-1}$ - non-irrigated, $0.28 \mathrm{~mm} \mathrm{~h}^{-1}$ - irrigated). These rates are only estimates of the true rate, one that is difficult to measure. The rates presented here are based on stem tips and are likely to be higher than rates for the entire canopy. This possibility has been demonstrated for Bromus tectorum canopies by Link et al. (1995c). The rates observed in this study are probably near maximum values for the day as they were collected just prior to midday. Rates will be lower at other times during the day. A better estimate would be achieved by the use of whole plant gas exchange data collected over an entire day.

The transpiration values obtained here should not be used to estimate the components of ET. They are not representative of all the vegetation on the surface nor are they representative of the time scale used in ET estimates for the surface.

Net photosynthetic rates increased from near $3 \mu \mathrm{mol} \mathrm{m}^{-2} \mathrm{~s}^{-1}$ in February to $19.7 \mu \mathrm{mol} \mathrm{m}^{-2} \mathrm{~s}^{-1}$ in the nonirrigated treatment. In the irrigated treatment, values were at a maximum of $17.9 \mu \mathrm{mol} \mathrm{m}^{-2} \mathrm{~s}^{-1}$ in June, dropping to $10.1 \mu \mathrm{mol} \mathrm{m} \mathrm{m}^{-2} \mathrm{~s}^{-1}$ in July (Figure 5.13). No differences were found in treatments on any of the five days $(\mathrm{p}>0.05)$. 


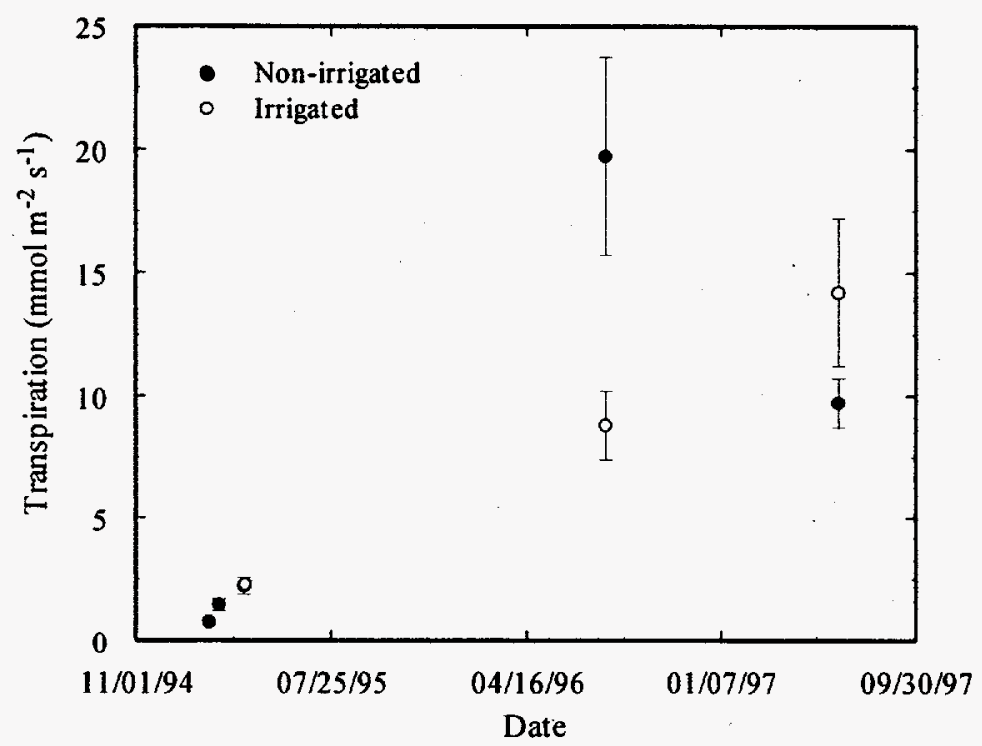

Figure 5.12. Transpiration Rates for Artemisia tridentata Collected in WY-1995, WY-1996, and WY-1997 in the Irrigated and Non-irrigated Treatments.

(WY-1997 data collected on June 18, 1997. Error bars are one standard error of the mean.)

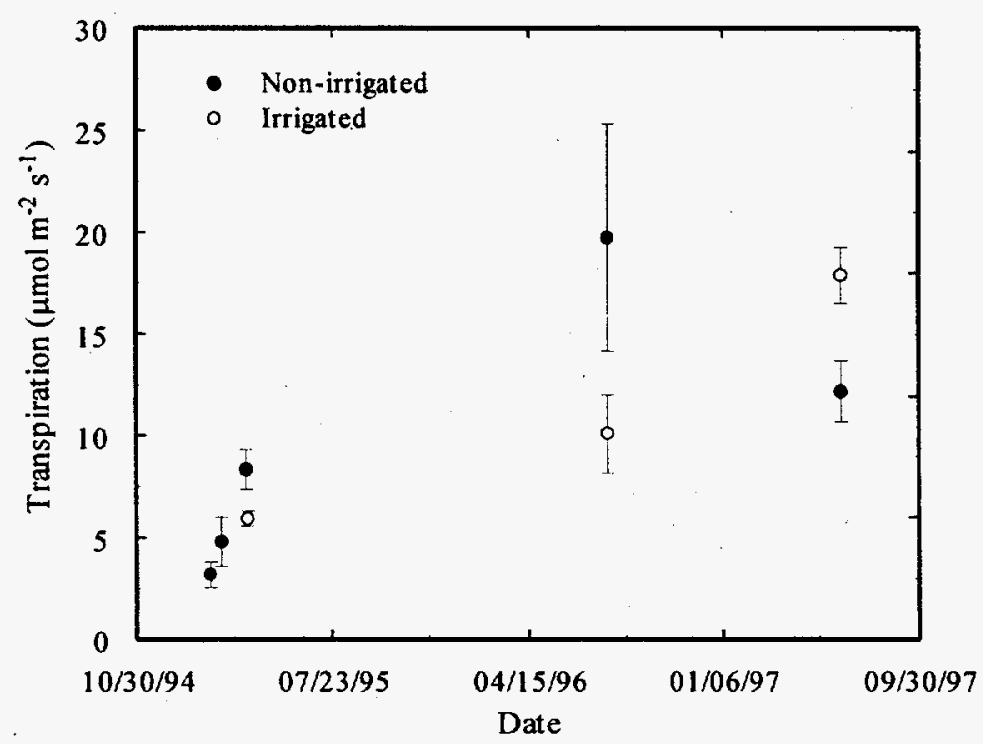

Figure 5.13. Net Photosynthesis in Artemisia tridentata Collected in WY-1995, WY-1996, and WY-1997 in the Irrigated and Non-irrigated Treatments. (WY-1997 data collected on June 18, 1997. Error bars are one standard error of the mean.) 


\subsubsection{Root Study}

Root observations were taken using a Circon Agricultural Camera in clear mini-rhizotron tubes inclined at a $45^{\circ}$ angle. Six mini-rhizotrons were placed in the irrigated and non-irrigated halves of the surface. Observations were taken from July 13 to July 21 in 1995, in June 1996, and on September 18, 1997. In WY-1997, only three tubes were examined in each treatment. The videos of each root tube were examined to compute root length density. The method was to count each root that intersected with the tube surface and each intersecting branching root from a root already in contact with the tube. In WY-1995 and WY-1996, all roots observed were considered to be alive. In 1997, roots were counted separately for live and dead roots. Live roots are white to brown and turgid with some roots having root hairs. Dead roots are dark in color and contracted within root channels in the soil. Differentiating live from dead roots is subjective. Root counts were taken in an area the width of the viewing area $(1.55 \mathrm{~cm})$ and $10 \mathrm{~cm}$ long. The count data were then divided by the observation area to yield a root length density value (Upchurch and Ritchie 1983). Root length data are presented with respect to treatment, year, and depth in Figure 5.14.
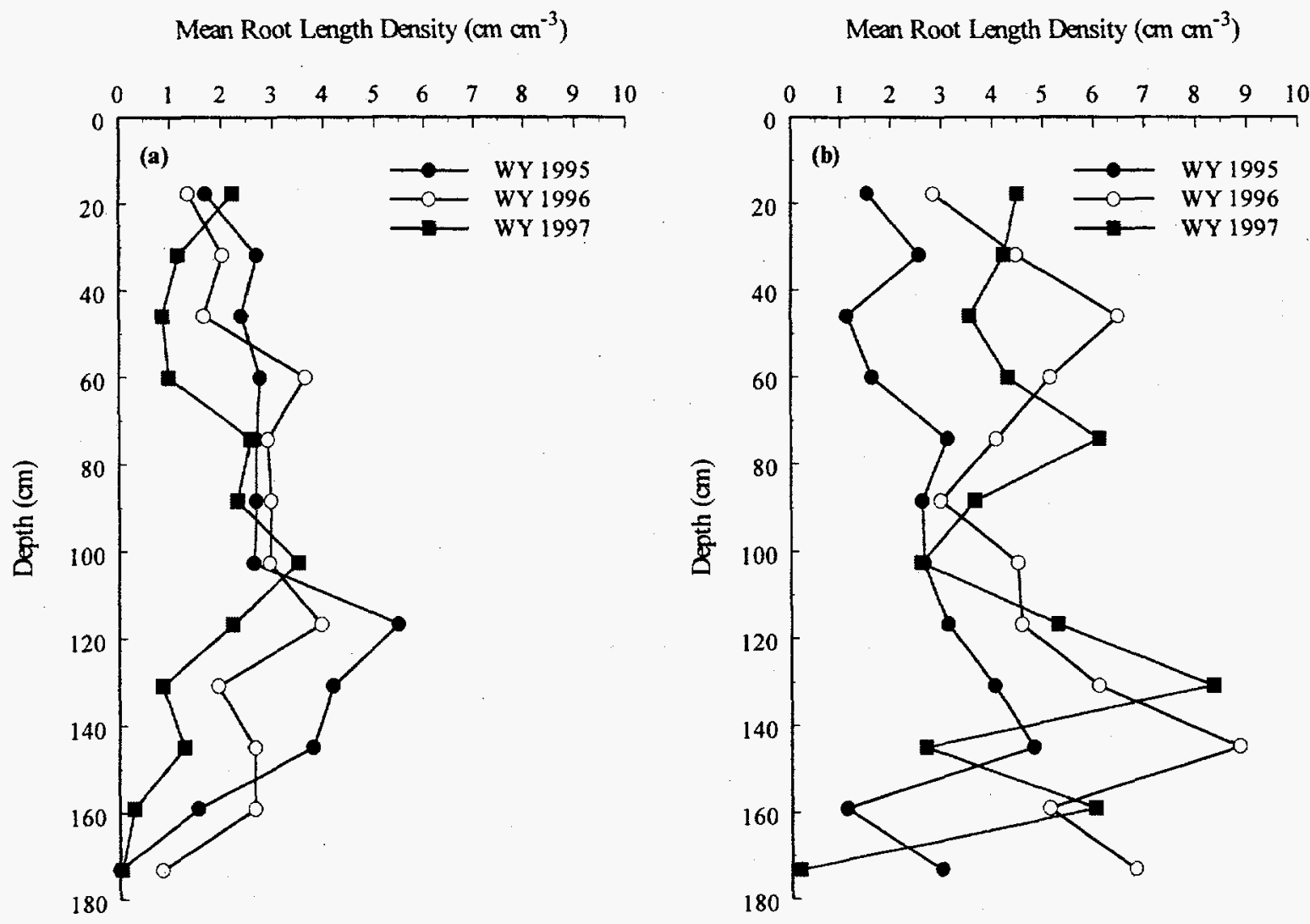

Figure 5.14. Mean Root Length Density as a Function of Depth in WY-1995, WY-1996, and WY-1997. ([a] the non-irrigated treatment and, [b] the irrigated treatment.) 
Root length density exhibits little pattern with depth other than a decrease near the bottom in WY1997. Mean root length density over depths and holes was significantly greater in the irrigated treatment than in the non-irrigated treatment in WY-1996 and WY-1997 (Figure 5.15).

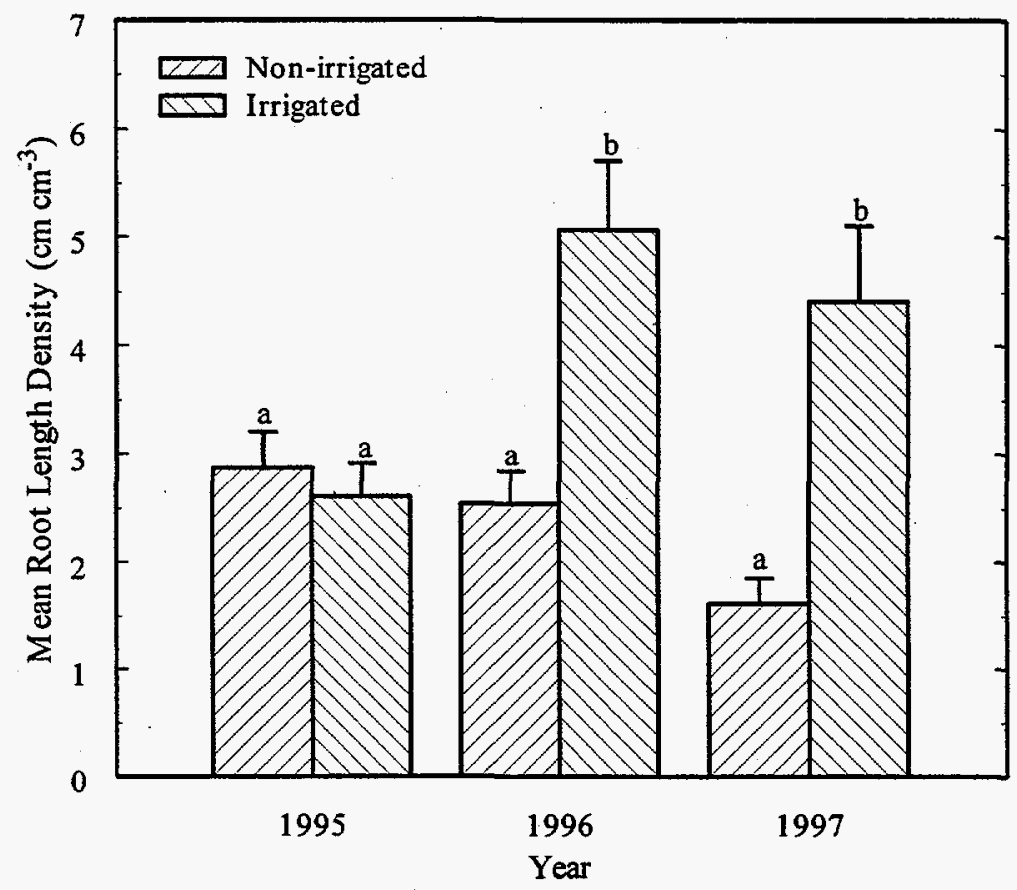

Figure 5.15. Mean Root Length Density over Depths and Holes in WY-1995, WY-1996, and WY-1997 for the Non-irrigated and Irrigated Treatments. (Error bars are one standard error of the mean. Means with differing letters within years are significantly different.)

During WY-1995 and WY-1996, no attempt was made to distinguish live from dead roots. By WY1997, dead roots became obvious, and both live and dead root length density were quantified. This data is expressed as the ratio of dead to live root length density with depth (Figure 5.16). The mean ratio of dead to live root length density over depths and holes was significantly different with a ratio of $0.25 \pm$ 0.08 in the irrigated treatment and $1.14 \pm 0.24$ in the non-irrigated treatment.

\subsubsection{Survivorship}

In WY-1995, WY-1996, and WY-1997 a census of live and dead shrubs was conducted in all 300 quadrats. The mean survivorship of the shrubs for each year was compared with respect to the treatment (Figure 5.17). Chrysothamnus nauseosus survivorship was significantly greater in the irrigated treatment than in the non-irrigated treatment. In contrast, survivorship of $A$. tridentata was significantly greater in 


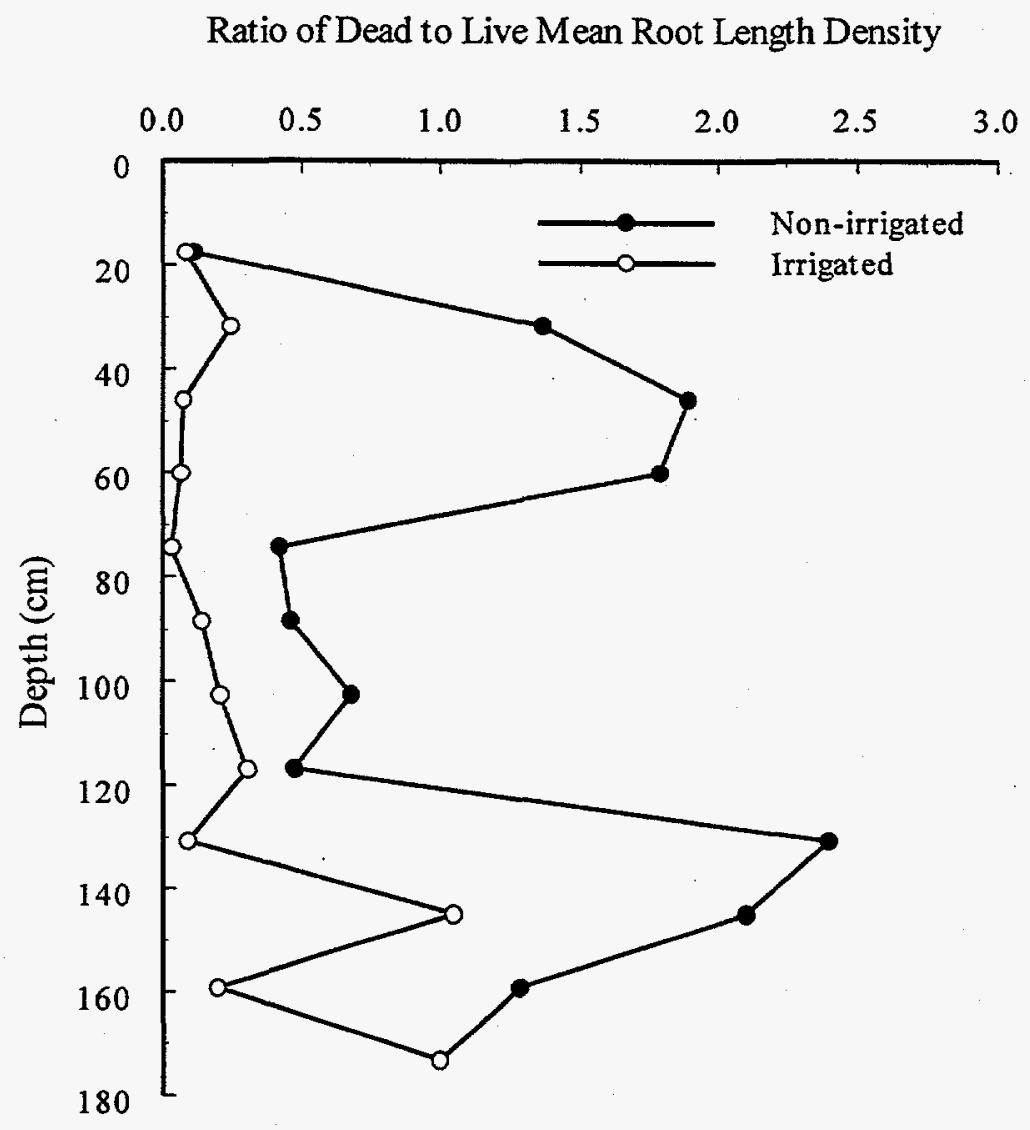

Figure 5.16. Mean Ratio of Dead to Live Root Length Density in WY-1997 for the Non-irrigated and Irrigated Treatments.

the non-irrigated treatment than in the irrigated treatment. The loss of $A$. tridentata in the irrigated treatment continued in WY-1997 with survivorship dropping to $91 \%$. Survivorship of $A$. tridentata across treatments remains much greater than survivorship of $C$. nauseosus.

\subsubsection{Reproduction}

In WY-1997, data were collected to test the hypothesis that irrigation reduces the percentage of Artemisia tridentata shrubs with mature seed heads, compared with the non-irrigated treatment. Data to test the hypothesis were obtained by estimating the percentage of $A$. tridentata shrubs with mature seed heads that were present in both treatments. Sampling was done by selecting the $3 \mathrm{rd}$, and 6 th through the 15 th rows south of the north border in the irrigated treatment and the 3rd, and 6th through 15 th rows north of the south border in the non-irrigated treatment. In each row, the number of individual shrubs with mature floral heads present and absent was recorded. 


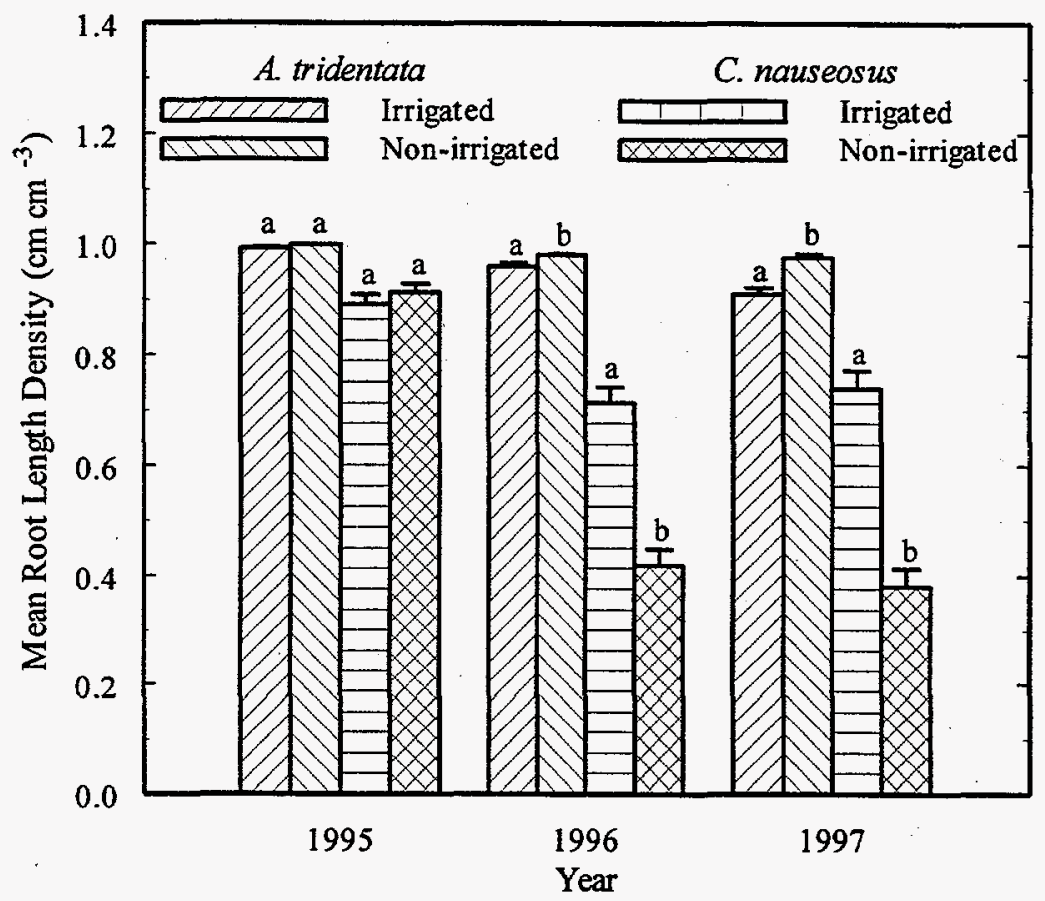

Figure 5.17. Mean Survivorship for Artemisia tridentata and Chrysothamnus nauseosus in WY-1995, WY-1996, and WY-1997 for the Non-irrigated and Irrigated Treatments. (Error bars are one standard error of the mean. Means with differing letters within years and species are significantly different.)

The percentage of shrubs with mature seed heads $(\mathrm{P})$ was computed as:

$$
P=100(N / T)
$$

where $N$ is the number of shrubs in each row with mature seed heads and $T$ is the total number of shrubs in the row. Each row is considered an experimental unit where $P$ is the observation. A total of five replicate experimental units was observed in each treatment. Student's t-test was used to test the hypothesis.

The percentage of $A$. tridentata with mature seed heads in the irrigated treatment was significantly $(p=0.009)$ lower than in the non-irrigated treatment (Table 5.5). The irrigated treatment had only $62.3 \%$ of the $A$. tridentata shrubs with mature seed heads and the non-irrigated treatment had $80.6 \%$. This result is another indication (Gee et al. 1996) that $A$. tridentata is less viable on this surface with three times normal precipitation than with non-irrigated precipitation. 
Table 5.5. Percentage of Artemisia tridentata Shrubs with Mature Seed Heads in the Irrigated and Non-irrigated Treatments.

\begin{tabular}{|l|c|c|}
\hline \multicolumn{1}{|c|}{ Treatment } & Mean \% & SE \\
\hline Irrigated & 62.3 & 3.7 \\
\hline Non-irrigated & 80.6 & 3.8 \\
\hline
\end{tabular}

Observations were also made of seedling establishment of $A$. tridentata and $C$. nauseosus in WY1997. In late spring, numerous seedlings of both species occurred in both treatments. By late summer, most of the seedlings had perished. Even so, a significant number of $A$. tridentata seedlings were at least one year old and were up to $5 \mathrm{~cm}$ tall. More recruitment of new shrubs is expected next season.

\subsection{Animal Observations}

Animal evidence on the surface was casually noted in WY-1995 and quantified in WY-1996 and WY-1997. In WY-1996 and WY-1997, evidence of animal presence (feces and holes) was noted by surface inspection in all 300 quadrats. In WY-1996, observations were made between May 24 and June 7. In WY-1997 observations were made on April 25. The depths of selected holes were measured on September 12.

In WY-1996, animal evidence (feces and holes) was found in $20 \%$ of the quadrats in the nonirrigated half of the barrier and in $8 \%$ of the quadrats in the irrigated half. Nine holes observed on the surface. In WY-1997, feces were present in $93 \%$ of the quadrats in the non-irrigated half of the barrier and in $69 \%$ of the quadrats in the irrigated half (Figure $5.18 \mathrm{a}$ ). The 10 holes observed on the surface in WY-1997 are shown in Figure 5.18b. Also in Figure 5.18b are two holes located in the quadrat at position 17 Easting, 67 Northing. Animal evidence consisted almost exclusively of rabbit feces.

In both treatments, animal evidence increased from WY-1996 to WY-1997. Evidence was much stronger or easier to observe in the non-irrigated half during both years, compared with the irrigated half of the barrier. As can be seen by examining the maps in Figures 5.1 and 5.6, an association exists between animal evidence and litter cover. It is possible that animal evidence is truly the same in each treatment but, because of the greater vegetative and litter cover in the irrigated half, the ability to observe the evidence is reduced.

Holes burrowed into the surface were little changed between WY-1996 and WY-1997. It is likely that some of the same holes were seen in both years. The holes were not counted, so it was not possible to document a true change over the two years. The vertical depth of two holes on the surface were measured and found to be shallow; one was $7.5 \mathrm{~cm}$ and the other $8 \mathrm{~cm}$ deep. These holes were the largest ones ( $<10 \mathrm{~cm}$ in diameter) found on the surface. Holes dug by burrowing animals are much more common in undisturbed areas (Link et al. 1995b). As a result, burrowing activity is likely to increase as the ecosystem becomes more similar to that of undisturbed areas. 

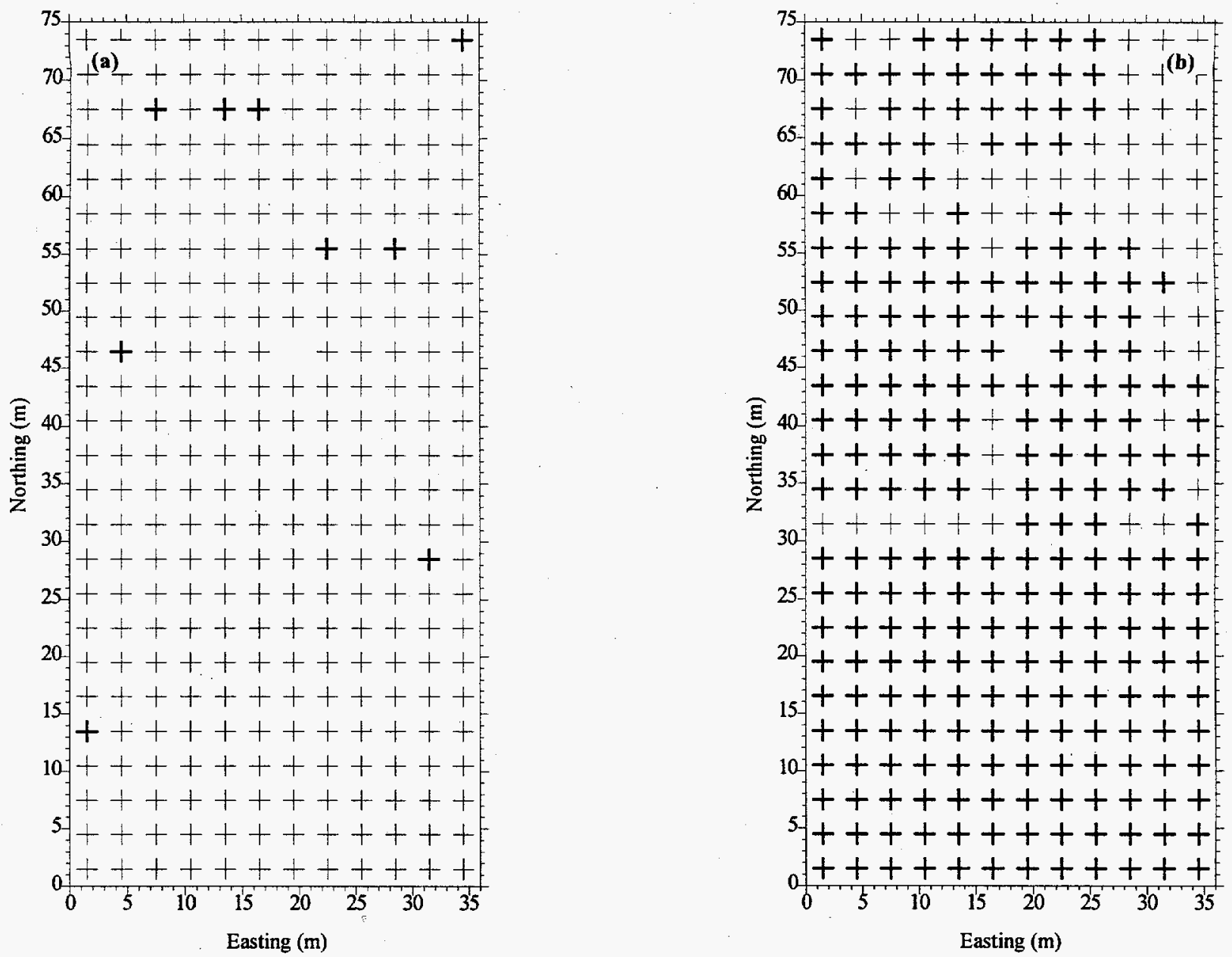

Figure 5.18. Animal Evidence in Each Quadrat on the Surface. ([a] location of holes and, [b] location of feces Dark symbols indicate evidence, such as holes and feces.)

\subsection{Summary and Conclusions}

The establishment on the surface, after three years, of a viable and highly diverse plant community continues to have a significant effect on the surface function. The complete coverage by deep-rooted perennials has completely dried out the soil cap, even with three times normal precipitation. The plant community has accommodated the excess precipitation with more vegetative matter. In addition, the plants have virtually eliminated any evidence of wind and water erosion. Continued monitoring of the plant community, and its capability to maximize ET and minimize erosion, is needed beyond the third year to ensure this progress continues. 


\subsection{Overall Barrier Performance Issues}

A major objective of this treatability test is to evaluate overall performance of a surface barrier under actual waste site conditions (DOE 1993). The previous sections have, in turn, discussed barrier performance related to water balance, water erosion and stability, wind erosion, and biointrusion. Each section has documented observations for the past three years of the surface barrier treatability test at the 200 BP Operable Unit. In general, the observations have been encouraging and suggest that because of quality construction and design, the barrier is meeting performance criteria in all the tested categories. However, several issues remain that are related to water intrusion into wastes and the stability of the vegetative component. These issues will be discussed in order.

The design basis for the surface barrier used in this treatability test has been documented previously (Myers and Duranceau 1994). The intent of the barrier design was to optimize individual barrier components to ensure long-term (minimum 1000-year) control of water infiltration, stability, erosion, and noxious gas emissions (DOE 1993). The most rigid performance standard relates to net water infiltration through the barrier to the waste zone, for which the control limit was set at $0.5 \mathrm{~mm} \mathrm{yr}^{-1}$. This limit will be discussed in light of the data obtained from the barrier during the past three years of testing.

\subsection{Water Infiltration Control}

A control limit of $0.5 \mathrm{~mm} \mathrm{yr}^{-1}$ for water infiltration is very stringent. It is equivalent to requiring the barrier must limit water flow into the waste to mass flux rates of less than $2 \times 10^{-9} \mathrm{~cm} \mathrm{~s}^{-1}$ (assuming unit hydraulic-gradient conditions). While restrictive, this level of hydraulic control has been found in tests of RCRA cover designs which employ composite covers (that is, plastic geomembrane overlying compacted clay) and, therefore, will be considered an acceptable design standard for RCRA equivalent barriers (Melchior et al. 1994).

The drainage system used in the treatability test barrier is capable of resolving flux rates of less than $0.1 \mathrm{~mm} \mathrm{yr}^{-1}$ (see Section 2). The composite error in measurement, due to evaporation and seepage in the dosing-siphon collector vault, is less than $0.1 \mathrm{~mm} \mathrm{yr}^{-1}$; consequently, the system used to measure the drainage is adequate for testing this performance standard. The rationale is to test the barrier against the performance criteria, based on measured drainage that has occurred from the soil or side slopes to the underlying curbed asphalt drainage collection system (Figure 1.2). As indicated in Section 2, laboratory and field data indicate the asphalt drainage collection system currently has an extremely low permeability (equivalent to $0.01 \mathrm{~mm} \mathrm{yr}^{-1}$ or less). If the drainage flux through the soil, as measured by the dosing siphons, is less than $0.5 \mathrm{~mm} \mathrm{yr}^{-1}$, it is clear the barrier meets the design specifications, because, in reality, the flux through the soil and the asphalt layer is less than $0.01 \mathrm{~mm} \mathrm{yr}^{-1}$. Continued monitoring of the dosing siphons will provide useful information on trends and changes in drainage from the soil.

Over the past three years, a maximum of $0.20 \mathrm{~mm}$ of water has drained from the northeast section of the irrigated soil cover, while all other soil sections have shown no drainage. This situation suggests the surface soil is working as a nearly perfect capillary barrier, one that stores water without drainage in the 
winter months and subsequently releases water (via evapotranspiration) during the rest of the year. What is not known, and may not be easily tested, is the long-term performance of the asphalt. Based on present performance of the soil cover (essentially no drainage), even if the asphalt were to fail completely (hypothetically due to some unknown mechanism), the environmental consequences would be minimal. The impact of asphalt failure would be felt more in terms of the side slope performance and the impact of side slope drainage on the underlying waste.

Side slope drainage remains a design issue for above-grade barriers that have barren gravel or rock side slopes. During the past three years, rates of side slope drainage have ranged from $20 \mathrm{~mm} \mathrm{yr}^{-1}$ to more than $200 \mathrm{~mm} \mathrm{yr}^{-1}(10$ to $40 \%)$ of the applied precipitation. These elevated water fluxes can have significant impact on underlying wastes. However, the variation in hydraulic properties at the site makes it difficult to predict the exact impact of this drainage water on the waste and possible subsequent groundwater contamination. Thus, in the design of a final barrier, it may be necessary to plan for diverting the drainage water away from the waste site. The asphalt sublayer is designed to shed the drainage water away from the waste zone, much like an umbrella sheds water. By laterally extending the asphalt layer, the water is shed further from the buried waste. Obvious economic considerations determine how large to make the barrier and how far to extend the asphalt. Also, at some locations, a risk exists in shedding the water onto an adjacent waste site. Under conditions of persistent drainage from side slopes, the durability of the asphalt layer becomes more important. If the asphalt degrades in the foreseeable future, water fluxes in areas closer to the waste will increase and may ultimately impact the groundwater adversely. An integrated analysis of the impacts of the timing and extent of asphalt degradation, coupled with the variation in side slope drainage, would help to assess the importance of this issue to long-term barrier performance.

\subsection{Surface Stability}

The data obtained to date suggest the surface is stable. Because of its steepness, the rock side slope is the most vulnerable part of the barrier. Movement of the rock side slope was limited to less that $2 \mathrm{~cm}$ in the three years of testing. It is unlikely that even this rate of movement will continue in a linear fashion; however, only further periodic monitoring can determine the long-term movement. No measurable tectonic (earthquake) activities have occurred during the test period, so no definitive evidence indicates the rock side slope will remain stable under an extreme shock. However, the threat of instability appears to be low and should remain so for several millennia or more (Wing et al. 1995). No significant settlement of the soil cover was observed. The slight increase in elevation measured during the past three years is attributed to the combination of freeze-thaw events and the impact of plant root invading the surface soil and displacing soil, creating a less dense surface. Higher organic matter content obtained in surface soils from the barrier support the biotic hypothesis.

\subsection{Erosion}

Wind and water erosion have had virtually no impact on the surface barrier during the past three years. With stable gravel and rock side slopes, the only issue is the soil cover. In the fall of 1994, a slight amount (less than $0.001 \mathrm{~cm}$ ) of soil loss from wind erosion occurred during the 2-month period between the construction and the restoration phases of the barrier development. Since that time, no 
measurable loss has been observed. During the past winter when the soil was frozen, runoff events (Section 2) were observed. But these events produced no soil loss. Acceptable soil losses are estimated at $0.03 \mathrm{~cm} \mathrm{yr}^{-1}$ for surface covers (DOE 1995). The measured amount of less than $0.001 \mathrm{~cm}$ in less than three years appears to meet that criteria easily. Speculation about the permanency of the soil cover is dependent upon future scenarios. Fire, drought, and farming could adversely impact the erosion stability of the soil surface. The most dramatic of these three would be farming, which would disrupt the native vegetation and, during certain periods of time, leave the surface fallow and subject to wind erosion. In the absence of farming or other man-induced manipulations, the surface will likely remain quite stable. Restoration after fires and even drought conditions still leaves organic matter and biomass on the surface that can anchor it against both wind and water erosion. Nevertheless, the pea gravel admixture in the top $1 \mathrm{~m}$ of the soil cover would act to stabilize the barrier and reduce its erodibility.

\subsection{Surface Restoration and Biointrusion}

A remaining concern is the stability of the vegetation after surface restoration, considering some rather dramatic shifts in the vegetation during the past three years. During the first year, after restoration with a sagebrush, rabbit brush, and a mixed grass composite, an invasion of tumbleweed quickly stabilized the surface and protected it against wind and water erosion in addition to helping to recycle soil water to the atmosphere. Since that time, all of the tumble weed has been removed by natural processes and the shrubs have become established. In addition, in the irrigated (north) portion of the barrier, a significant increase in the abundance of grasses and a relative decrease in the amount of shrubs has happened, particularly in the northeast sector. It was in the northeast sector of the soil surface that drainage was measured this past year.

Changes in vegetation can have rather dramatic impacts on the hydrology of the surface cover. Shifts from bare surfaces to revegetated, transplanted surfaces to weed-invaded surfaces to shrubdominated surfaces all within a space of three years reflects the dynamics of the system. The end of this dynamic is not foreseeable. It is possible that at some time in the future a fire or drought or both will can change the vegetation mix completely (see Section 5). A likely scenario is for a fire to occur with the resultant takeover of the surface with cheat grass (Leopold 1966, Rickhard et al. 1988). Cheatgrass with shallow roots and shorter life cycle can dramatically alter the water balance of a site (Gee et al. 1992). Monitoring of vegetation type and density on the barrier continues to be a key requirement in the assessment of present and long-term barrier performance. 


\subsection{Quality Assurance}

The prototype barrier testing is operated under the Quality Assurance (QA) plan OHE-002, Rev.5, a controlled document located in the project files and with each task leader. This plan is the guiding document for the testing on the prototype surface barrier. Specific test procedures are identified in the QA plan and include procedures for irrigation applications, snow applications, dosing siphon measurements, and a series of water content measurements and soil and aggregate analysis. Data reduction related to drainage and water balance measurements are emphasized in the test plan and the quality assurance plan. Data from water infiltration, water storage measurements, wind and water erosion and biointrusion tasks are collected and input into laboratory record books (LRBs) and into data loggers and electronic data files. These files are formatted for subsequent graphical display and analysis. Detailed records are kept and hard copy files are maintained at the task level. The test results and data are compiled in data summary reports and are periodically reviewed. The QA procedures are reviewed annually.

Procedures that are specific to the prototype barrier project include the following:

PNL-PSB-2.0 Procedure for Measuring Soil Moisture Using the Neutron Probe in the Neutron Access Tube Vertical and Horizontal Arrays.

PNL-PSB-3.0 Irrigation Applications.

PNL-PSB-4.0 Snow Applications.

PNL-PSB-5.0 Dosing Siphon Monitoring.

PNL-PSB-6.0 Pan Lysimeter Under Asphalt Pad Monitoring Protocol.

Data analysis focuses on quantifying barrier performance. Quantification of water balance is made on selected test areas and reported at least on an annual basis. During FY 1997, irrigation and water storage data were provided to Bechtel Hanford, Inc. on a monthly basis as part of the formal reporting system. Wind and water erosion and biotic intrusion will be reported on a more qualitative basis, but where possible, measurement error and uncertainties will be documented. 


\subsection{References}

Allen, E.B. 1988. Some trajectories of succession in Wyoming sagebrush grassland: implications for restoration. E.B. Allen, editor. pp. 89-112. In The reconstruction of disturbed arid lands. ALAS Selected Symposium, Westview Press, Boulder, Colorado.

ASTM. 1984. Standard method for particle-size analysis of soils. D422-63, American Society for Testing and Materials, Philadelphia, Pennsylvania.

Daubenmire, R. 1959. A canopy-coverage method of vegetational analysis. Northwest Sci. 33:43-64.

Fryrear, D.W. 1986. A Field Dust Sampler. J. Soil and Water Conservation 41(2):117-120.

Gardner, W. H. 1986. Water Content. p 493-544. In Methods of Soil Analysis, part 1. Physical and Mineralogical Methods- Agronomy Monograph no. 9 ( $2^{\text {nd }}$ Edition), American Society of Agronomy, Madison, WI.

Gee, G.W., M.L. Rockhold, J.L. Downs. 1989. Status of FY 1988 soil-water balance studies on the Hanford site. PNL-6750, Pacific Northwest Laboratory, Richland, Washington.

Gee, G. W., M. J. Fayer, M. L. Rockhold, and M. D. Campbell. 1992. Variations in Recharge at the Hanford Site. Northwest Sci. 66:237-250

Gee, G.W., L.L. Cadwell, H.D. Freeman, M.W. Ligotke, S.O. Link, R.A. Romine, and W.H. Walters, Jr. 1993a. Testing and monitoring plan for the permanent isolation surface barrier prototype. PNL-8391, Pacific Northwest Laboratory, Richland, Washington.

Gee, G.W., D.G. Felmy, J.L. Downs, J.C. Ritter, M.D. Campbell, M.J. Fayer, R.R. Kirkham, and S.O. Link. 1993b. Field lysimeter test facility status report IV: FY 993. PNL- 8911, Pacific Northwest Laboratory, Richland, Washington.

Gee, G.W., H.D. Freeman, W.H. Walters, Jr., M.W. Ligotke, M.D. Campbell, A.L. Ward, S.O. Link, S.K. Smith, B.G. Glimore, and R.A. Romine. 1994. Hanford prototype surface barrier status report: FY 1994. PNL-10275. Pacific Northwest Laboratory, Richland, Washington.

Gee, G.W., A.L. Ward, B.G. Gilmore, M.W. Ligotke, and S.O. Link. 1995. Hanford prototype-barrier status report: FY 1995. Pacific Northwest National Laboratory, Richland, Washington.

Gee, G.W., A.L. Ward, B.G. Gilmore, S.O. Link, G.W. Dennis, and T.K. O’Neil. 1996. Hanford prototype-barrier status report FY 1996. PNNL-11367. Pacific Northwest National Laboratory, Richland, Washington.

Gee, G.W., N.R. Wing, and A.L. Ward. 1997. Development and Testing of Permanent Isolation Surface Barriers at the Hanford Site. pp. D3-D22. In Barrier Technologies for Environmental Management. National Academy Press, Washington, D.C. 
Gilmore, B.G., and W.H. Walters. 1993. Water erosion field tests for Hanford protective barriers: $F Y$ 1992 status report. PNL-8949, Pacific Northwest Laboratory, Richland, Washington.

Hitchcock, C.L., and A. Cronquist. 1973. Flora of the Pacific Northwest. University of Washington Press, Seattle, Washington, $730 \mathrm{pp}$.

Hoitink, D.J., and K.W. Burk. 1995. Climatological Data Summary 1996, with Historical Data. PNL11471, Pacific Northwest Laboratory, Richland, Washington.

Hudson, N. 1981. Soil Conservation. English Language Book Society, London, England, 324 pp.

Kemp, P.R. 1989. Seed banks and vegetation processes in deserts. Ecology of soil seed banks (M.A. Leck, V.T. Parker, and R.L. Simpson, eds.), pp. 367-384. Academic Press, Inc., San Diego, California.

Leopold, A. 1966. A Sand County Almanac. Oxford University Press, New York. pp 154-157.

Ligotke, M.W., and D.C. Klopfer. 1990. Soil erosion rates from mixed soil and gravel surfaces in a wind tunnel. PNL-7435, Pacific Northwest Laboratory, Richland, Washington.

Ligotke, M.W. 1993. Soil erosion rates caused by wind and saltating sand stresses in a wind tunnel. PNL-8478, Pacific Northwest Laboratory, Richland, Washington.

Link, S.O. 1995. Establishment of Vegetation on the Prototype Surface. In: Hanford site protective barrier development program: Fiscal year 1994 highlights K.L. Petersen, S.O. Link, G.W. Gee, eds. PNL-10605, Pacific Northwest Laboratory, Richland, Washington.

Link, S.O., G.W Gee, and J. L. Downs. 1990. The effect of water stress on phenological and ecophysiological characteristics of cheatgrass and Sandbergs's bluegrass. J. Range Management 43:506513.

Link, S.O., G.W. Gee, M.E. Thiede, and P.A. Beedlow. 1990. Response of a shrub-steppe ecosystem to fire: Soil water and vegetational change. Arid Soils Research and Rehabilitation. 4:163-172.

Link, S.O., W.J. Waugh, J.L. Downs, M.E. Thiede, J.C. Chatters, and G.W. Gee. 1994. Effects of coppice dune topography and vegetation on soil water dynamics in a cold-desert ecosystem. J. Arid Environments. 27: 265-278.

Link, S.O., L.L. Cadwell, M.R. Sackschewsky, D.S. Landeen, and K.L. Petersen. 1995a. The role of plants and animals in isolation barriers: Hanford, Washington. PNL-10788, Pacific Northwest Laboratory, Richland, Washington.

Link, S.O., N.R. Wing, and G.W. Gee. 1995b. The development of permanent isolation barriers for buried wastes in cool deserts: Hanford, Washington. Journal of Arid Land Studies 4: 215-224.

Link, S.O., H. Bolton, Jr, M.E. Thiede, and W.H. Rickard. 1995c. Responses of downy brome to nitrogen and water. J. Range Management 48: 290-297.

Melchior, S., K. Berger, B. Vielhaber, and G. Miehlich. 1994. Multilayered Landfill Covers: Field 
Data on the Water Balance of Liner Performance. In In-situ Remediation: Scientific Basis for Current and Future Technologies. G.W. Gee and N. R. Wing eds. Battelle Press, Columbus, Ohio.

Myers, D.R., and D.A. Duranceau (eds.). 1994. Prototype Hanford surface barrier: Design basis document. BHI-00007, Bechtel Hanford, Inc., Richland, Washington.

Neter, J. and W. Wasserman. 1974. Applied Linear Statistical Models. R. D. Irwin, Inc., Homewood, Illinois, $842 \mathrm{pp}$.

Petersen, K.L., J.C. Chatters, and W.J. Waugh. 1993. Long-term Climate Change Assessment Study Plan for the Hanford Site Permanent Isolation Barrier Development Program. WHD-EP-0569 Rev. 1, Westinghouse Hanford Company, Richland, Washington.

Petersen, K.L., S.O. Link, and G.W. Gee. 1995. Hanford Site long-term surface barrier development program: Fiscal year 1994 highlights. PNL-10605, Pacific Northwest Laboratory, Richland, Washington.

Rogers, L. E., and W. H. Rickard. 1988. Introduction: shrub-steppe lands. In Shrub-steppe balance and change in a semi-arid terrestrial ecosystem. W.H. Rickard, L.E. Rogers, B. E. Vaughn, and S. F. Liebetrau, eds. Elsevier, Amsterdam.

Rose, A.W., and W.Guo. 1995. Thermal convection of soil air on hillsides. Environmental Geology, 25:258-262.

Sall, J., Ng, K., and Hecht, M. 1991. Statistical visualization for the Macintosh (JMP). SAS Institution, Inc., Cary, North Carolina.

Sehmel, G.A. 1980. Particle Resuspension: A Review. Environ Int. 4:107-122.

Sehmel, G.A. 1984. Deposition and Resuspension. In Atmos Sci and Power Prod. DOE/TIC-27601, pp 533-583, National Technical Information Center, Office of Scientific and Technical Information, Oak Ridge, Tennessee.

Seigal 1956. Nonparametric Statistics for the Behavioral Sciences. McGraw-Hill Book Comp., New York, $312 \mathrm{pp}$.

Szeicz, G., G. Endrodi, and S. Tajchman. 1969. Aerodynamic and surface factors in evaporation. Water Resour. Res. 5:380-394.

Upchurch, D.R.and J. T.Ritchie. 1983. Root observations using a video recording system in minirhizotrons. Agronomy J. 75:1009-1015.

U. S Department of Energy (DOE). 1993. Treatability test plan for the 200-BP-1 prototype surface barrier. DOE/RL-93-27 Rev.0. United States Department of Energy, Richland, Washington.

U. S. Department of Energy (DOE). 1995. Focused feasiblity study of engineered barrier for waste management units in the 200 areas. DOE/RL-93-33 Rev.0. United States Department of Energy, Richland, Washington 
Ward, A.L., and G.W. Gee. 1997. Performance Evaluation of a Field-Scale Surface Barrier. J. Environ. Qual. 26:694-705.

Wing, N.R. 1994. Permanent isolation surface barrier development plan. WHC-EP-0673, Westinghouse Hanford Company, Richland, Washington.

Wing, N.R., and G.W. Gee. 1994. Quest for the Perfect Cap. Civil Engineering 64(10):388-41.

Wing, N. R., F. M. Corpuz, K. L. Petersen, and A. M. Tallman. 1995. Physical stability of long-term surface barriers-assessment of potentially disruptive natural events. BHI-00144. Bechtel Hanford, Inc, Richland, Washington.

Wischmeier, W.H., D.D. Smith, and R. E. Uhland. 1958. Evaluation of Factors in the Soil-Loss Equation. Agric. Eng. 39(8): 458-462

Wischmeier, W.H., and D.D. Smith. 1978. Predicting Rainfall Erosion Losses- A Guide to Conservation Planning. U.S. Dept. Agr., Agr. Handbook 537. 


\subsection{Barrier Publications}

1. Phillips, S. J., M. R. Adams, T. W. Gilbert, C. C. Meinhardt, R. M. Mitchell, and W. J. Waugh. 1985. "Engineered Barrier Test Facility Status Report: 1984." RHO-WM-SR-3P, Rockwell Hanford Operations, Richland, Washington.

2. Phillips, S. J., T. W. Gilbert, and M. R. Adams. 1985. "Preliminary Engineering Specifications for a Test Demonstration Multilayer Protective Barrier Cover System." RHO-WM-EV-8 P, Rockwell Hanford Operations, Richland, Washington.

3. Fayer, M. J., W. Conbere, P. R. Heller, and G. W. Gee. 1985. "Model Assessment of Protective Barrier Designs." PNL-5604, Pacific Northwest Laboratory, Richland, Washington.

4. Myers, D. R. 1985. "Disposal Materials Study." RHO-WP-EV-12P, Rockwell Hanford Operations, Richland, Washington.

5. Adams, M. R., and M. F. Kaplan. 1986. "Marker Development for Hanford Waste Site Disposal." In Waste Management '86, (Vol. 1), pp. 425-431, ed. R. G. Post. University of Arizona, College of Engineering and Mines, Tucson, Arizona.

6. Phillips, S. J., and J. N. Hartley. 1986. "Protective Barrier Systems for Final Disposal of Hanford Waste Sites." In Waste Management '86, (Vol. 1), pp. 433-437, ed. R. G. Post. University of Arizona, College of Engineering and Mines, Tucson, Arizona.

7. Kaplan, M. F., and M. R. Adams. 1986. "Using the Past to Protect the Future: Marking Nuclear Waste Disposal Sites." Archeology 39(5):51-54.

8. Adams, M. R., and N. R. Wing. 1986. "Protective Barrier and Warning Marker System Development Plan." RHO-RE-OL-35P, Rockwell Hanford Operations, Richland, Washington.

9. Fayer, M. J. 1987. "Model Assessment of Protective Barrier Designs: Part II." PNL-6297, Pacific Northwest Laboratory, Richland, Washington.

10. Last, G. V., M. A. Glennon, M. A. Young, and G. W. Gee. 1987. "Protective Barrier Materials Analysis: Fine Soil Site Characterization." PNL-6314, Pacific Northwest Laboratory, Richland, Washington.

11. Gee, G. W. 1987. "Preliminary Analysis of the Performance of the Protective Barrier and Marker System." In Final Environmental Impact Statement, Disposal of Hanford Defense HighLevel, Transuranic and Tank Wastes, Appendix M, DOE/EIS-0113, U.S. Department of Energy Richland, Operations Office, Richland, Washington.

12. Kirkham, R. R., G. W. Gee, and J. L. Downs. 1987. "Field Lysimeter Test Facility for Protective Barriers: Experimental Plan." PNL-6351, Pacific Northwest Laboratory, Richland, Washington. 
13. Waugh, W. J., and S. O. Link. 1988. "Barrier Erosion Control Test Plan: Gravel Mulch, Vegetation, and Soil Water Interactions." WHC-EP-0067, Westinghouse Hanford Company, Richland, Washington.

14. Wing, N. R., M. D. Campbell, J. L. Downs, G. W. Gee, R. R. Kirkham, and S. J. Phillips. 1988. "Protective Barrier Development: The Field Lysimeter Test Facility." In Proceedings of the International Topical Meeting on Nuclear and Hazardous Waste Management Spectrum '88, pp. 196-198. American Nuclear Society, Inc., La Grange Park, Illinois, WHCSA-0203-FP, Westinghouse Hanford Company, Richland, Washington.

15. Phillips, S. J., M. S. Ruben, and R. R. Kirkham. 1988. "Engineered Surface Barriers for Waste Disposal Sites: Lysimeter Facility Design and Construction." In DOE Model Conference Proceedings, pp. 1229-1238. CONF-881054. Oct. 3-7, Martin Marietta, Oak Ridge, Tennessee.

16. Ligotke, M. W. 1988. "Soil Erosion Rates from Mixed Soil and Gravel Surfaces in a Wind Tunnel: A Preliminary Report." PNL-6677, Pacific Northwest Laboratory, Richland, Washington.

17. Waugh, W. J., and M. G. Foley. 1988. "Protective Barrier Climate-Change Impacts: Technical Workshop Findings and Recommendations." PNL-6615, Pacific Northwest Laboratory, Richland, Washington.

18. Ligotke, M. W. 1989. "Surface Stability Test Plan for Protective Barriers." PNL-6722, Pacific Northwest Laboratory, Richland, Washington.

19. Gee, G. W., R. R. Kirkham, J. L. Downs, and M. D. Campbell. 1989. "The Field Lysimeter Test Facility (FLTF) at the Hanford Site: Installation and Initial Tests." PNL-6810, Pacific Northwest Laboratory, Richland, Washington.

20. Gee, G. W., M. D. Campbell, H. D. Freeman, and J. F. Cline. 1989. "Assessment of Cover Systems at the Grand Junction, Colorado, Uranium Mill Tailings Pile: 1987 Field Measurements." PNL-6762, Pacific Northwest Laboratory, Richland, Washington.

21. Petersen, K. L. 1989. "The Long-Term Climate Change Assessment Task of the Hanford Site, Washington Protective Barrier Development Program." WHC-SA-0537-FP, Westinghouse Hanford Company, Richland, Washington.

22. Cadwell, L. L., L. E. Eberhardt, and M. A. Simmons. 1989. "Animal Intrusion Studies for Protective Barriers: Status Report for FY 1988." PNL-6869, Pacific Northwest Laboratory, Richland, Washington.

23. Freeman, H. D., G. W. Gee, and J. F. Relyea. 1989. "Field Study Plan for Alternate Barriers." PNL-6840, Pacific Northwest Laboratory, Richland, Washington.

24. Freeman, H. D., and G. W. Gee. 1989. "Hanford Protective Barriers Program Asphalt Barrier Studies - FY 1988." PNL-6874, Pacific Northwest Laboratory, Richland, Washington. 
25. Waugh, W. J. 1989. "Gravel Admix, Vegetation and Soil Water Interactions in Protective Barriers: Experimental Design, Construction and Initial Conditions." PNL-6616, Pacific Northwest Laboratory, Richland, Washington.

26. Freeman, H. D., and G. W. Gee. 1989. "Hanford Protective Barriers Program: Status of Asphalt Barrier Study - FY 1989." PNL-7513, Pacific Northwest Laboratory, Richland, Washington.

27. Link, S. O., and W. J. Waugh. 1989. "Evapotranspiration Studies for Protective Barriers: Experimental Plans." PNL-6899, Pacific Northwest Laboratory, Richland, Washington.

28. Petersen, K: L. 1990. "The Long-Term Climate Change Assessment Task of the Protective Barrier Development Program for Low-Level Waste Site Remediation at the Hanford Site, Washington." In High Level Radioactive Waste Management. Vol 2, pp. 1235-1239. Proceeding of an International Topical Meeting. American Nuclear Society, La Grange Park, Illinois. (WHC-SA-0808-FP, Westinghouse Hanford Company, Richland, Washington).

29. Fayer, M. J. 1990. "Test Plan for Hydrologic Modeling of Protective Barriers." PNL-7152, Pacific Northwest Laboratory, Richland, Washington.

30. Wing, N. R., and G. W. Gee (eds.). 1990. "Hanford Site Protective Barrier Development Program: Fiscal Year 1989 Highlights." WHC-EP-0318, Westinghouse Hanford Company, Richland, Washington.

31. Campbell, M. D., G. W. Gee, M. J. Kanyid, and M. L. Rockhold. 1990. "Field Lysimeter Test Facility: Second Year (FY 1989) Test Results." PNL-7209, Pacific Northwest Laboratory, Richland, Washington.

32. Landeen, D. S., L. L. Cadwell, L. E. Eberhardt, R. E. Fitzner, and M. A. Simmons. 1990. "Animal Intrusion Field Test Plan." WHC-EP-0253, Westinghouse Hanford Company, Richland, Washington.

33. Link, S. O., M. E. Thiede, R. D. Evans, J. L. Downs, and W. J. Waugh. 1990. "Evapotranspiration Studies for Protective Barriers: FY 1988 Status Report." PNL-6985, Pacific Northwest Laboratory, Richland, Washington.

34. Relyea, J. F., M. R. Sackschewsky, and W. J. Waugh. 1989. "Small-Tube Lysimeter Facility Status Report for Fiscal Year 1989." WHC-EP-0297, Westinghouse Hanford Company, Richland, Washington.

35. Walters, W. H., K. A. Hoover, and L. L. Cadwell. 1990. "Project Test Plan for Runoff and Erosion on Fine-Soil Barrier Surfaces and Rock-Covered Side Slopes." PNL-6791, Pacific Northwest Laboratory, Richland, Washington.

36. Hoover, K. A., L. L. Cadwell, and W. H. Walters. 1990. "Hanford Protective Barriers Program: Water Erosion Studies - FY 1989." PNL-7214, Pacific Northwest Laboratory, Richland, Washington. 
37. Landeen, D. S. 1990. "Animal Intrusion Status Report for Fiscal Year 1989." WHC-EP-0299, Westinghouse Hanford Company, Richland, Washington.

38. Ligotke, M. W., and D. C. Klopfer. 1990. "Soil Erosion Rates from Mixed Soil and Gravel Surfaces in a Wind Tunnel." PNL-7435, Pacific Northwest Laboratory, Richland, Washington.

39. Waugh, W. J., M. E. Thiede, C. J. Kemp, L. L. Cadwell, and S. O. Link. 1990. "Field Study of Gravel Admix, Vegetation, and Soil Water Interactions: Protective Barrier Program Status Report - FY 1989." PNL-7440, Pacific Northwest Laboratory, Richland, Washington.

40. Hunter, C. R., A. J. Busacca, and W. J. Waugh. 1990. "A Feasibility Study of Modeling Pedogenic Carbonates in Soils and Sediments at the U.S. Department of Energy's Hanford Site." PNL-7413, Pacific Northwest Laboratory, Richland, Washington.

41. Wing, N. R., and G. W. Gee. 1990. "Protective Barrier Development: Overview." In Proceedings of the Twenty-Eighth Hanford Symposium on Health and the Environment, Environmental Monitoring, Restoration, and Assessment: What Have We Learned?, pp. 147151, ed. R. H. Gray, Pacific Northwest Laboratory, Richland, Washington. WHC-SA-0619 FP, Westinghouse Hanford Company, Richland, Washington.

42. Wing, N. R., and G. W. Gee. 1990. "Protective Barrier Development: Overview." In Proceedings of the International Topical Meeting on Nuclear and Hazardous Waste Management Spectrum '90, pp. 335-337. American Nuclear Society, Inc., La Grange Park, Illinois. WHCEP-0380, Westinghouse Hanford Company, Richland, Washington.

43. Glantz, C. S., M. N. Schwartz, K. W. Burk, R. B. Kaspar, M. W. Ligotke, and D. J. Perrault. 1990. "Climatological Summary of Wind and Temperature Data for the Hanford Meteorology Monitoring Network." PNL-7471, Pacific Northwest Laboratory, Richland, Washington.

44. Campbell, M. D., and G. W. Gee. 1990. "Field Lysimeter Test Facility: Protective Barrier Test Results (FY 1990, The Third Year)." PNL-7558, Pacific Northwest Laboratory, Richland, Washington.

45. Sackschewsky, M. R., J. C. Chatters, S. O. Link, and C. A. Brandt. 1991. "Protective Barrier Program: Test Plan for Plant Community Dynamics." WHC-EP-0380. Westinghouse Hanford Company, Richland, Washington.

46. Nichols, W. E. 1991. "Comparative Simulations of a Two-Layer Landfill Barrier Using the Help Version 2.0 and UNSAT-H Version 2.0 Computer Codes." PNL-7583, Pacific Northwest Laboratory, Richland, Washington.

47. Landeen, D. S. 1991. "Animal Intrusion Status Report for Fiscal Year 1990." WHC-EP-0398. Westinghouse Hanford Company, Richland, Washington.

48. Campbell, M. D., G. W. Gee, R. R. Kirkham, S. J. Phillips, and N. R. Wing. 1991. "Water Balance Lysimetry at a Nuclear Waste Site." In Proceedings of the International Symposium on Lysimetry, pp. 125-134, ed. R. G. Allen, American Soc. Civil Engr., New York. 
49. Kirkham, R. R., M. L. Rockhold, G. W. Gee, M. J. Fayer, M. D. Campbell, and L. J. Fritschen. 1991. "Lysimeters: Data acquisition and analysis." In Proceedings of the International Symposium on Lysimetry, pp. 362-370, ed. R. G. Allen, American Soc. Civil Engr., New York.

50. Phillips, S. J., J. F. Relyea, C. J. Kemp, N. R. Wing, M. D. Campbell, G. W. Gee, M. J. Graham, R. R. Kirkham, and M. S. Rubin. 1991. "Development of Hanford Site Lysimeter Facilities." In Proceedings of the International Symposium on Lysimetry, pp. 19-27, ed. R. G. Allen. American Soc. Civil Engr., New York.

51. Waugh, W. J., M. E. Thiede, L. L. Cadwell, G. W. Gee, H. D. Freeman, M. R. Sackschewsky, and J. F. Relyea. 1991. "Small Lysimeters for Documenting Arid Site Water Balance." In Proceedings of the International Symposium on Lysimetry, pp. 151-159, ed. R. G. Allen. American Soc. Civil Engr., New York.

52. Cadwell, L. L. (ed.). 1991. "Hanford Site Protective Barrier Development Program: Fiscal Year 1990 Highlights." PNL-7831, Pacific Northwest Laboratory, Richland, Washington.

53. Petersen, K. L. 1991. "Modern and Pleistocene Climatic Patterns in the West." WHC-EP-0523, Westinghouse Hanford Company, Richland, Washington.

54. Chatters, J. C., and H. A. Gard. 1991. "Archaeological Mounds as Analogs of Engineered Covers for Waste Disposal Sites Literature Review and Progress Report." PNL-7718, Pacific Northwest Laboratory, Richland, Washington.

55. Sackschewsky, M. R., C. J. Kemp, L. L. Cadwell, M. E. Thiede, and W. J. Waugh. 1991. "Status Report for the Small-Tube Lysimeter Facility Fiscal Year 1990." WHC-EP-0381, Westinghouse Hanford Company, Richland, Washington.

56. Fayer, M. J., M. L. Rockhold, and D. J. Holford. 1992. "Model Assessment of Protective Barriers: Part III Status of FY 1990 Work." PNL-7975, Pacific Northwest Laboratory, Richland, Washington.

57. Petersen, K. L. 1992. "A Warm and Wet Little Climate Optimum and a Cold and Dry Little Ice Age in the Southern Rocky Mountains, U.S.A." WHC-SA-1382-FP. Westinghouse Hanford Company, Richland, Washington.

58. Link, S. O., J. L. Downs, M. E. Thiede, D. J. Lettau, T. R. Twaddell, and R. A. Black. 1992. "Evapotranspiration Studies for Protective Barriers: FY 1990 Status Report." PNL-8032, Pacific Northwest Laboratory, Richland, Washington.

59. Link, S. O., M. E. Thiede, J. L. Downs, D. J. Lettau, and W. J. Waugh. 1992.

"Evapotranspiration Studies for Protective Barriers: FY 1989 Status Report." PNL-8033, Pacific Northwest Laboratory, Richland, Washington.

60. Fayer, M. J., M. L. Rockhold, and M. D. Campbell. 1992. "Hydrologic Modeling of Protective Barriers: Comparison of Field Data and Simulation Results." Soil Sci. Soc. Am. J., 56:690-700. 
61. Wing, N. R. 1992. "A Peer Review of the Hanford Site Permanent Isolation Surface Barrier Development Program." WHC-MR-0392. Westinghouse Hanford Company, Richland, Washington.

62. Gee, G. W., M. J. Fayer, M. L. Rockhold, and M. D. Campbell. 1992. "Variations in Recharge at the Hanford Site." Northwest Sci.,

$66: 237-250$.

63. Gee, G. W., M. D. Campbell, G. S. Campbell, and J. H. Campbell. 1992. "Rapid Measurement of Low Soil Water Potentials Using A Water Activity Meter." Soil Sci. Soc. Am. J., 56:10681070 .

64. Ligotke, M. W. 1993. "Soil Erosion Rates Caused by Wind and Saltating Sand Stresses in a Wind Tunnel." PNL-8478, Pacific Northwest Laboratory, Richland, Washington.

65. Fayer, M. J. 1993. "Model Assessment of Protective Barriers: Part IV, Status of FY 1992 Work." PNL-8498, Pacific Northwest Laboratory, Richland, Washington.

66. Wing, N. R., and G. W. Gee. 1993. "The Development of Permanent Isolation Surface Barriers: Hanford Site, Richland, Washington, U.S.A." In Proceedings of Geoconfine '93, pp. 357-362. June 8-11, 1993, Montpellier, France. WHC-SA-1799-FP, Westinghouse Hanford Company, Richland, Washington.

67. Petersen, K. L., J. C. Chatters, and W. J. Waugh. 1993. "Long-Term Climate Change Assessment Study Plan for the Hanford Site Permanent Isolation Barrier Development Program." WHC-EP-0569 Rev. 1, Westinghouse Hanford Company, Richland, Washington.

68. Wing, N. R. 1993. "The Results of Laboratory Test to Determine the Physical Properties of Various Barrier Construction Materials." WHC-SD-ER-DP-006, Westinghouse Hanford Company, Richland, Washington.

69. Gee, G. W., L. L. Cadwell, H. D. Freeman, M. W. Ligotke, S. O. Link, R. A. Romine, and W. H. Walters, Jr. 1993. "Testing and Monitoring Plan for the Permanent Isolation Surface Barrier Prototype." PNL-8391, Pacific Northwest Laboratory, Richland, Washington.

70. Cadwell, L. L., S. O. Link, and G. W. Gee. 1993. "Hanford Site Permanent Isolation Surface Barrier Development Program: Fiscal Year 1992 and 1993 Highlights." PNL-8741, Pacific Northwest Laboratory, Richland, Washington.

71. Link, S. O., R. N. Kickert, M. J. Fayer, and G. W. Gee. 1993. "A Comparison of Simulation Models for Predicting Soil Water Dynamics in Bare and Vegetated Lysimeters." PNL-8675, Pacific Northwest Laboratory, Richland, Washington.

72. Sackschewsky, M. R., C. J. Kemp, and L. L. Cadwell. 1993. "Status Report for the Small-Tube Lysimeter Facility Fiscal Year 1992." WHC-EP-0597, Westinghouse Hanford Company, Richland, Washington. 
73. Petersen, K. L., and J. C. Chatters. 1993. "Long-Term Climate Change Assessment Task for the Hanford Site Permanent Isolation Barrier Development Program: Status through FY 1992." WHC-EP-0644, Westinghouse Hanford Company, Richland, Washington.

74. Chamness, M. 1993. "An Investigation of Bergmounds as Analogs to Erosion Control Factors on Protective Barriers." PNL-8841, Pacific Northwest Laboratory, Richland, Washington.

75. Bjornstad, B. N., and S. S. Teel. 1993. "Natural Analog Study of Engineered Protective Barriers at the Hanford Site." PNL-8840, Pacific Northwest Laboratory, Richland, Washington.

76. U.S. Department of Energy (DOE). 1993. "Treatability Test Plan for the 200-BP-1 Prototype Surface Barrier." DOE/RL-93-27, Department of Energy, Richland, Washington.

77. Gee, G. W., D. Felmy, J. C. Ritter, R. R. Kirkham, S. O. Link, J. L. Downs, and M. J. Fayer. 1993. "Field Lysimeter Test Facility: Status Report IV." PNL-8911, Pacific Northwest Laboratory, Richland, Washington.

78. Gaylord, D. R., L. D. Stetler, G. D. Smith, and R. W. Mars. 1993. "Summary of 1990 Eolian Characterization Studies, Hanford Site, Washington." PNL-8862, Pacific Northwest Laboratory, Richland, Washington.

79. Wing, N. R. 1993. "Permanent Isolation Surface Barrier: Functional Performance." WHC-EP0650, Westinghouse Hanford Company, Richland, Washington.

80. Gilmore, B. G., and W. H. Walters. 1993. "Water Erosion Field Tests for Hanford Protective Barriers: FY 1992 Status Report." PNL-8949, Pacific Northwest Laboratory, Richland, Washington.

81. Kirkham, R. R. 1993. "Comparison of Surface Energy Fluxes with Satellite-Derived Surface Energy Flux Estimates from a Shrub-Steppe." PNL-9003, Pacific Northwest Laboratory, Richland, Washington.

82. U.S. Department of Energy (DOE) 1993. "Report on Value Engineering Study of Permanent Isolation Surface Barrier and Warning Marker System Development Plan at the Hanford Site." DOE/RL/12074--8, Department of Energy, Richland, Washington.

83. Wing, N. R. 1994. "Permanent Isolation Surface Barrier Development Plan." WHC-EP-0673, Westinghouse Hanford Company, Richland, Washington.

84. Waugh, W. J., J. C. Chatters, G. V. Last, B. N. Bjornstad, S. O. Link, and C. R. Hunter. 1994. "Barrier Analogs: Long-Term Performance Issues, Preliminary Studies, and Recommendations." PNL-9004, Pacific Northwest Laboratory, Richland, Washington.

85. Link, S. O., L. L. Cadwell, C. A. Brandt, J. L. Downs, R. E. Rossi, and G. W. Gee. 1994. "Biointrusion Test Plan for the Permanent Isolation Surface Barrier Prototype." PNL-9411, Pacific Northwest Laboratory, Richland, Washington. 
86. Kirkham, R. R., and G. W. Gee. 1994. "Experimental Plan and Construction Guidance for Hanford Protective Barrier Test at Hill AFB, Utah." PNL-9412, Pacific Northwest Laboratory, Richland, Washington.

87. Freeman, H. D., and R. A. Romine. 1994. "Hanford Permanent Isolation Barrier Program: Asphalt Technology Test Plan." PNL-9336, Pacific Northwest Laboratory, Richland, Washington.

88. Link, S. O., W. J. Waugh, J. L. Downs, M. E. Thiede; J. C. Chatters, and G. W. Gee. 1994. "Effects of Coppice Dune Topography and Vegetation on Soil Water Dynamics in a Cold-Desert Ecosystem." J.Arid Environ. 27: 265-278.

89. Waugh, W. J., M. E. Thiede, D. J. Bates, L. L. Cadwell, G. W. Gee, and C. J. Kemp. 1994. "Plant Cover and Water Balance in Gravel Admixtures at an Arid Waste-Burial Site." J. Environ. Qual. 23:676-685.

90. Landeen, D. S. 1994. "The Influence of Small Mammal Burrowing Activity on Water Storage at the Hanford Site." WHC-EP-0730, Westinghouse Hanford Company, Richland, Washington.

91. USDOE. 1994. "Constructability Report for the 200-BP-1 Prototype Surface Barrier." DOE/RL-94-76, U.S. Department of Energy, Richland Operations Office, Richland, Washington.

92. Myers, D. R., and D. A. Duranceau (eds.). 1994. "Prototype Hanford Surface Barrier: Design Basis Document." BHI-00007, Bechtel Hanford, Inc., Richland, Washington.

93. Wing, N. R., and G. W. Gee. 1994. "Quest for the Perfect Cap." Civil Engineering 64(10):3841.

94. Gee, G. W., and N. R. Wing (eds.). 1994. In-Situ Remediation: Scientific Basis for Current and Future Technologies, Parts 1-2. Thirty-Third Hanford Symposium on Health and the Environment. November 7-11, 1994, Pasco, Washington. Battelle Press, Columbus, Ohio.

95. Wing, N. R., and G. W. Gee. 1994. "The Development of Surface Barriers at the Hanford Site." In G. W. Gee and N. R. Wing (eds.) pp. 427-440. In-Situ Remediation: Scientific Basis for Current and Future Technologies, Parts 1-2. Thirty-Third Hanford Symposium on Health and the Environment. November 7-11, 1994, Pasco, Washington. Battelle Press, Columbus, Ohio.

96. Waugh, W. J., K. L. Petersen, S. O. Link, B. N. Bjornstad, and G. W. Gee. 1994. "Natural Analogs of the Long-Term Performance of Engineered Covers." In G. W. Gee and N. R. Wing (eds.) pp. 379-410. In-Situ Remediation: Scientific Basis for Current and Future Technologies, Parts 1-2. Thirty-Third Hanford Symposium on Health and the Environment. November 7-11, 1994, Pasco, Washington. Battelle Press, Columbus, Ohio.

97. Freeman, H. D., and R. A. Romine. 1994. "Hanford Permanent Isolation Barrier Program: Asphalt Technology Development." In G. W. Gee and N. R. Wing (eds.) pp. 491-506. In-Situ Remediation: Scientific Basis for Current and Future Technologies, Parts 1-2. Thirty-Third Hanford Symposium on Health and the Environment. November 7-11, 1994, Pasco, 
Washington. Battelle Press, Columbus, Ohio.

98. Gilmore, B. G., and W. H. Walters. 1994. "Summary of Method Develop a Representative Equation for Soil Loss from the Hanford Permanent Isolation Barrier." In G. W. Gee and N. R. Wing (eds.) pp. 507-522. In-Situ Remediation: Scientific Basis for Current and Future Technologies, Parts 1-2. Thirty-Third Hanford Symposium on Health and the Environment. November 7-11, 1994, Pasco, Washington. Battelle Press, Columbus, Ohio.

99. Landeen, D. S. 1994. "The Influence of Small-Mammal Burrowing Activity on Water Storage at the Hanford Site." In G. W. Gee and N. R. Wing (eds.) pp. 523-544. In-Situ Remediation: Scientific Basis for Current and Future Technologies, Parts 1-2. Thirty-Third Hanford Symposium on Health and the Environment. November 7-11, 1994, Pasco, Washington. Battelle Press, Columbus, Ohio.

100. Ligotke, M. W. 1994. "Control of Eolian Soil Erosion from Waste-Site Surface Barriers." In G. W. Gee and N. R. Wing (eds.) pp. 545-560. In-Situ Remediation: Scientific Basis for Current and Future Technologies, Parts 1-2. Thirty-Third Hanford Symposium on Health and the Environment. November 7-11, 1994, Pasco, Washington. Battelle Press, Columbus, Ohio.

101. Link, S. O., W. J. Waugh, and J. L. Downs. 1994. "The Role of Plants in Isolation Barrier Systems." In G. W. Gee and N. R. Wing (eds.) pp. 561-592. In-Situ Remediation: Scientific Basis for Current and Future Technologies, Parts 1-2. Thirty-Third Hanford Symposium on Health and the Environment. November 7-11, 1994, Pasco, Washington. Battelle Press, Columbus, Ohio.

102. Myers, D. R., and N. R. Wing. 1994. "Hanford Site Protective Isolation Surface Barrier: Taking Research and Development to Engineered Application." In G. W. Gee and N. R. Wing (eds.) pp. 613-624. In-Situ Remediation: Scientific Basis for Current and Future Technologies, Parts 1-2. Thirty-Third Hanford Symposium on Health and the Environment. November 7-11, 1994, Pasco, Washington. Battelle Press, Columbus, Ohio.

103. Petersen, K. L. 1994. "The Long-Term Climate Change Task of the Hanford Permanent Isolation Barrier Development Program." In G. W. Gee and N. R. Wing (eds.) pp. 633-648. InSitu Remediation: Scientific Basis for Current and Future Technologies, Parts 1-2. Thirty-Third Hanford Symposium on Health and the Environment. November 7-11, 1994, Pasco, Washington. Battelle Press, Columbus, Ohio.

104. Gee, G. W., H. D. Freeman, W. H. Walters, M. W. Ligotke, M. D. Campbell, A. L. Ward, S. O. Link, S. K. Smith, B. G. Gilmore, and R. A. Romine. 1994. "Hanford Prototype Surface Barrier Status Report: FY 1994." PNL-10275, Pacific Northwest Laboratory, Richland, Washington.

105. Gaylord, D. R., and L. D. Stetler. 1994. "Aeolian-Climate Thresholds and Sand Dunes at the Hanford Site, South-Central Washington, U.S.A." J. Arid Environments 28:95-116.

106. Freeman, H. D., R. A. Romine, and A. H. Zacher. 1994. "Hanford Permanent Isolation Barrier Program: Asphalt Technology Data and Status Report - FY 1994." PNL-10194, Pacific Northwest Laboratory, Richland, Washington. 
107. Wing, N. R., G. W. Gee, and J. W. Cammann. 1995. "Program Management of a Multi-Year Technology Development Effort." PMNetwork 9(3):47-50.

108. Sackschewsky, M. R., C. J. Kemp, S. O. Link, and W. J. Waugh. 1995. "Soil Water Balance Changes in Engineered Soil Surfaces." J. Environ. Quality 24: 352-359.

109. Rockhold, M. L., M. J. Fayer, C. T. Kincaid, and G. W. Gee. 1995. "Estimation of Natural Ground Water Recharge for the Performance Assessment of a Low-Level Waste Disposal Facility at the Hanford Site." PNL-10508, Pacific Northwest Laboratory, Richland, Washington.

110. Link, S. O., M. E. Thiede, R. D. Evans, J. L. Downs, and G. W. Gee. 1995. "Responses of Big Sagebrush and Spiny Hopsage to Increasing Water Stress." In B. A. Roundy, E. D. McArthur, J. S. Haley, and D. K. Mann (eds.). Proceedings of the Wildland Shrub and Arid Land Restoration Svmposium, pp. 196-201. USDA-FS, Intermountain Research Station, Ogden, Utah.

111. Wing, N. R., F. M. Corpuz, K. L. Petersen, and A. M. Tallman. 1995. "Physical Stability of Long-Term Surface Barriers-Assessment of Potentially Disruptive Natural Events." BHI-00145, Bechtel Hanford, Inc., Richland, Washington.

112. Wing, N. R., K. L. Petersen, C. Whitlock, R. L. Burk. 1995. "Long-Term Climate Change Effects Task for the Hanford Site Permanent Isolation Barrier Development Program: Final Report." BHI-00144, Bechtel Hanford, Inc., Richland, Washington.

113. Duranceau, D. A. 1995. "Site Evaluation Report for Candidate Basalt Quarry Sites." BHI00005, Bechtel Hanford, Inc., Richland, Washington.

114. Fayer, M. J., and C. S. Simmons. 1995. Modified soil water retention functions for all matric suctions. Water Resour. Res. 31:1233-1238.

115. Petersen, K. L., S. O. Link, and G. W. Gee. 1995. Hanford Site Long-Term Surface Barrier Development Program: Fiscal Year 1994 Highlights. PNL-10605, Pacific Northwest Laboratory, Richland, Washington.

116. Link, S. O., N. R. Wing, and G. W. Gee. 1995. The development of permanent isolation barriers for buried wastes in cold deserts: Hanford, Washington. J. Arid Land Studies 4:215-224.

117. Link, S. O., L. L. Cadwell, K. L. Petersen, M. R. Sackshewsky, and D. S. Landeen. 1995. "The Role of Plants and Animals in Isolation Barriers at Hanford, Washington". PNL-10788. Pacific Northwest National Laboratory, Richland, Washington.

118. Gee, G. W., A. L. Ward, B. G. Gilmore, M. W. Ligotke, and S. O. Link. 1995. "Hanford Prototype-Barrier Status Report: FY 1995". PNL-10872. Pacific Northwest National Laboratory, Richland, Washington.

119. Gee, G. W., A. L. Ward, B. G. Gilmore, S. O. Link, G. W. Dennis, and T. K. O'Neil. 1996. "Hanford Prototype-Barrier Status Report: FY 1996". PNNL-1 1367. Pacific Northwest National Laboratory, Richland, Washington. 
120. USDOE. 1996. "Focused Feasibility Study of Engineered Barriers for Waste Management Units in the 200 Areas." DOE/RL-93-33. U. S. Department of Energy, Richland, Washington

121. Ward, A. L., and G. W. Gee. 1997. " Performance Evaluation of a Field-Scale Surface Barrier. J. Environ. Qual. 26: 694-705.

122. Gee, G. W., N. R. Wing, and A. L. Ward. 1997. "Development and Testing of Permanent Isolation Surface Barriers at the Hanford Site." pp. D3-D22. In Barrier Technologies for Environmental Management. National Academy Press, Washington, D. C.

123. Gee, G. W., and A. L. Ward. 1997. "Still in Quest of the Perfect Cap". pp.145-164. In T. D. Reynolds and R. C. Morris (eds.). Landfill Capping in the Semi-Arid West,-Conference Proceedings. Jackson Lake, Wyoming, May, 1997, Environmental Science and Research Foundation, Idaho Falls, Idaho.

124. Fayer, M. J., and G. W. Gee. 1997. "Hydrologic Model Tests for Landfill Covers Using Field Data." pp.53-68. In T. D. Reynolds and R. C. Morris (eds.). Landfill Capping in the Semi-Arid West,-Conference Proceedings. Jackson Lake, Wyoming, May, 1997, Environmental Science and Research Foundation, Idaho Falls, Idaho. 


\section{Distribution}

No. of

Copies

Offsite

2 DOE/Office of Scientific and Technical Information

J. Anderson Idaho State University

Department of Biology

Pocatello, ID 83209

2 Bechtel Nevada 2626 Losee Rd.

Las Vegas, NV 89030

ATTN: D. G. Levitt M. J. Sully

B. Bede

U.S. Ecology

509 E. 12th

Olympia, WA 98501

G. S. Campbell

Washington State University

Geology Department

Pullman, WA 99164

B. W. Drost

U.S. Geological Survey

1201 Pacific Ave., Suite 600

Tacoma, WA 98402

M. Dunkelman

Department of Health

Division of Radiation Protection

Airdustrial Park, Bldg. 5

P.O. Box 47827

Olympia, WA 98504-7827
No. of

Copies

S. F. Dwyer

Sandia National Laboratories

P.O. Box 5800

Albuquerque, NM 87185

3 Environmental Science and Research

Foundation

101 S. Park Ave, Suite 2

P.O. Box 51838

Idaho Falls, ID 83405-1838

ATTN: O. D. Markam

R. C. Morris

T. E. Reynolds

L. G. Everett

Geraghty \& Miller, Inc.

3700 State Street, Suite 350

Santa Barbara, CA 93105-3128

$5 \quad$ S. O. Link

Washington State University

Richland, WA 99352

J. Lommler

Jacobs Engineering Group, Inc. 2155 Louisiana Blvd. NE \#1000

Albuquerque, NM 87110-5414

C. Massimino

U.S. Environmental Protection Agency 1200 Sixth Avenue

Seattle, WA 90101

Distr.1 
No. of

Copies

S. R. McMullin

U. S. Department of Energy

Savannah River Site

P.O. Box A

Bldg. 703-46A

Aiken, SC 29802

2 Oak Ridge National Laboratory

P.O. Box 2008

Oak Ridge, TN 37831

ATTN: R. J. Luxmoore

E. D. Smith

G. N. Richardson

Hazen and Sawyer

4011 W. Chase Blvd.

Suite 500

Raleigh, NC 276073

B. R. Scanlon

Bureau of Economic Geology

University of Texas at Austin

University Station Box X

Austin, TX 78713-7508

M. G. Serrato

Westinghouse Savannah River

Company

SRTC Bldg. 773-42A

P.O. Box 616

Aiken, SC 29808

J. B. Sisson

Lockheed Martin Idaho

P.O. Box 1625

Idaho Falls, ID 83415-5218

E. Springer

Los Alamos National Laboratory

P.O. Box 1663

Los Alamos, NM 87545
No. of

Copies

D. Stone

Hill Air Force Base

Environmental Management Directorate

OO-ALC/EM

7276 Wardleigh Road

Hill AFB, UT 84056-5127

S. W. Tyler

Desert Research Institute

P.O. Box 60220

Reno, NV 89506

2 U. S. Geological Survey

333 W Nye Lane

Carson City, NV 89706

ATTN: B. J. Andraski

D. E. Prudic

2 U.S. Nuclear Regulatory Commission

Division of Engineering Safety

Waste Management Branch

11555 Rockville Pike

Rockville, MD 29852

ATTN: T. J. Nicholson

E. O'Donnell

W. J. Waugh

Chem Nuclear Geotech

P.O. Box 14000

Grand Junction, CO 81502

P. J. Wierenga

University of Arizona

Department of Soil and Water

429 Shantz Building

Tucson, AZ 85721

Distr.2 
No. of

Copies

Onsite

6 DOE Richland Operations Office

B. L. Foley

J. P. Hanson

$\mathrm{K} 2-18$

$\mathrm{K} 8-50$

O. Robertson

D. E. Trader

D. D. Wodrich

DOE-RL Reading Room (1)

13 Bechtel Hanford Incorporated

M. A. Buckmaster

H6-01

F. M. Corpuz

H4-85

J. W. Darby

V. R. Dronen

H4-85

$\mathrm{H} 0-09$

H0-17

G. B. Mitchem

H9-12

\section{Kaiser Engineers Hanford Company}

D. L. Fort

E6-50
No. of

Copies

54 Pacific Northwest Nátional Laboratory

J. R. Blacklaw

R. E. Clayton

G. W. Dennis

D. A. Faulk

M. J. Fayer

N. D. Foote (5)

M. D. Freshley

G. W. Gee (15)

P.S. Innes

C. T. Kincaid

R. R. Kirkham

W. J. Martin

P. D. Meyer

T. K. O'Neil

T. L. Page

W. A. Perkins

M. R. Sackschewsky

D. R. Sherwood

N. H. Uziemblo

A. L. Ward (10)

Technical Report Files (7)
DOE/REG

K9-33

K6-75

B5-01

K9-33

K8-14

K9-36

K9-33

B5-01

K9-33

K9-33

K9-14

K9-33

K6-75

K9-18

K9-36

K6-84

B5-01

B5-18

K9-33 